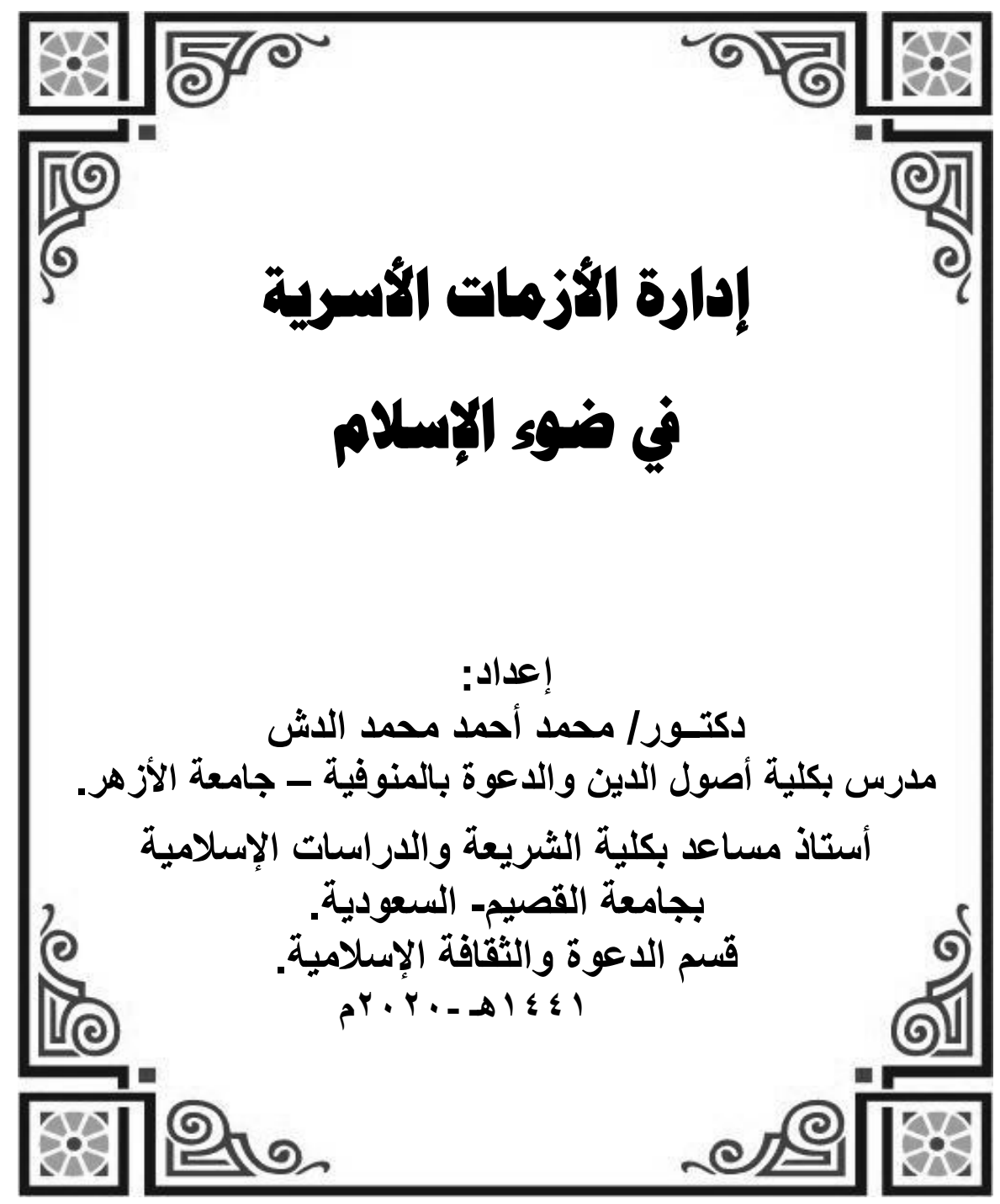


-O人. - 


\section{إدارة الأزمات الأسرية في ضوء الإسلام}

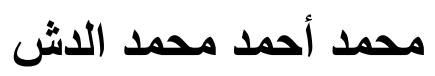

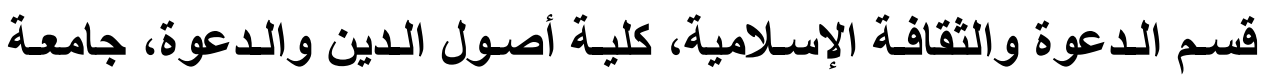

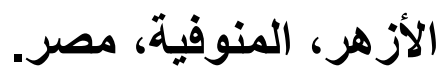

البريد الإلكتروني: mohammedaldish.adv@azhar.edu.eg

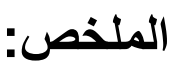

يهدف البحث إلى الإبانة عن الأسباب الداخلية والخارجية للأزمات الأسرية، وتوضيح أبرز خصائص وسمات مدير الأزمة الأسرية، وبيان

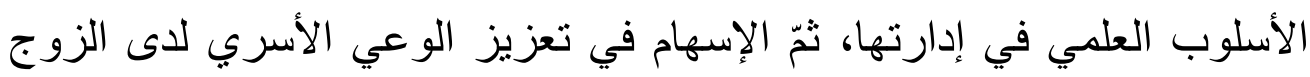

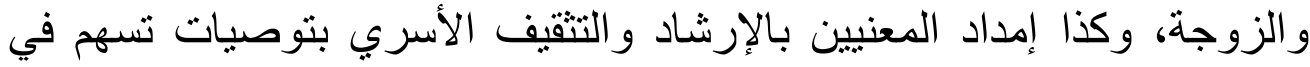

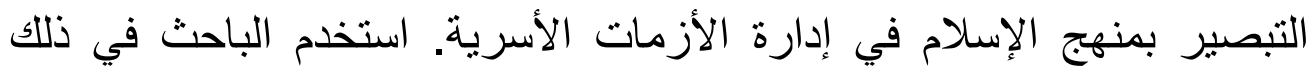

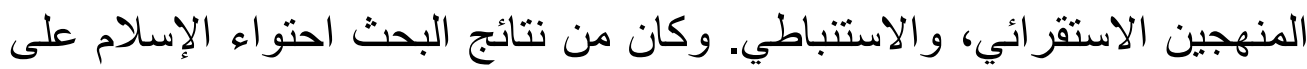

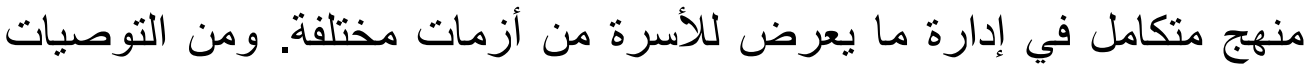

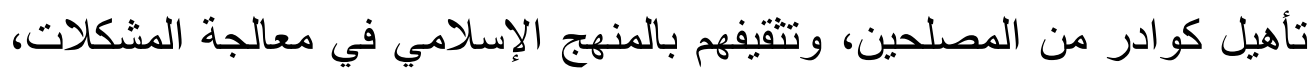
و إدارة الأزمات الأسرية عن طريق الدورات التدريبية، والندوات العلمية.

الكلمات المفتاحية: الإدارة ، الأزمة ، الأسرة ، الإسلام ، الاستقرار، 
Managing family crises in the light of Islam

Mohammed Ahmed Mohammed Eldesh

Department of Dawa and Islamic Culture, Faculty of Fundamentals of Religion and Dawa, Al-Azhar University, Menoufia, Egypt.

\section{Email: mohammedaldish.adv@azhar.edu.eg}

Abstract: The research aims to show the internal and external causes of the family crises, clarify the most prominent characteristics and features of the director of the family crisis. It also explains the scientific method of its treatment. Then, it contributes to strengthen the family awareness of the husband and wife, and grant those who are concerned with guiding and educating family some recommendations through giving them a deep knowledge of the Islamic approach of dealing with family crises. The researcher used in this research the inductive and deductive methods. One of the results of the research is that Islam has contained an integrated approach in managing the various crises arosed to the family. Among the recommendations are to qualify cadres of the reformers, and to educate them about the Islamic method in dealing with problems, and managing family crises through training courses and scientific seminars.

Keywords: Administration, Crisis, Family , Islam, stability , Challenges. 


\section{مقدمة}

إنّ الحمد الله، نحمده، ونستعينه، ونستهديه، ونعوذ بالله من شرور أنفسنا،

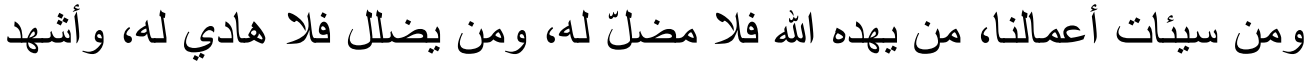

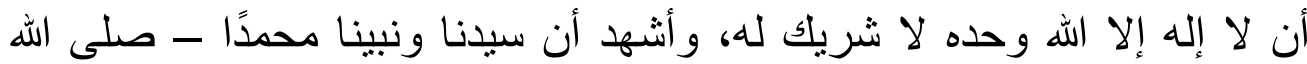

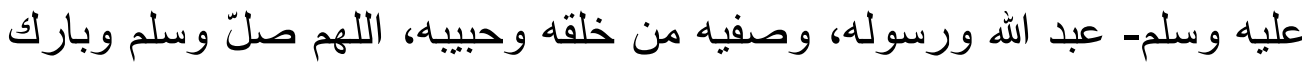
عليه، وعلى آله، وصحبه أجمعين، ومن تبعهم بإحسان إلى يوم الدين ..آمين.

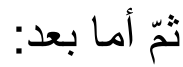

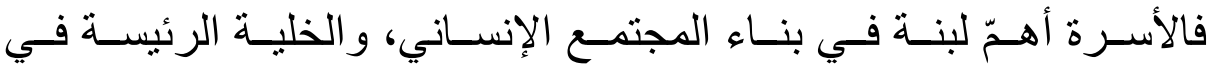

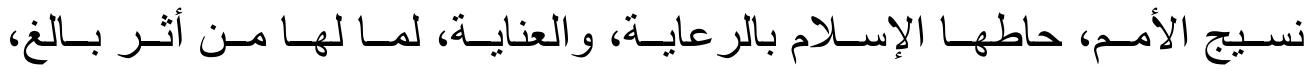

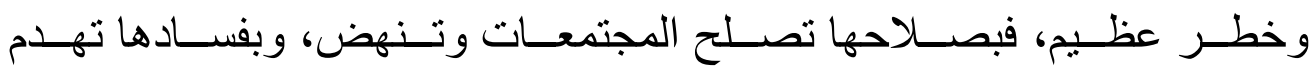

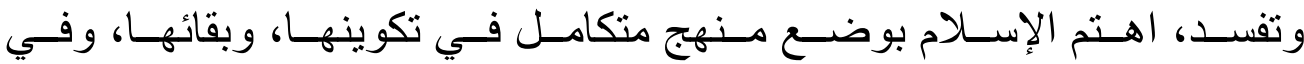

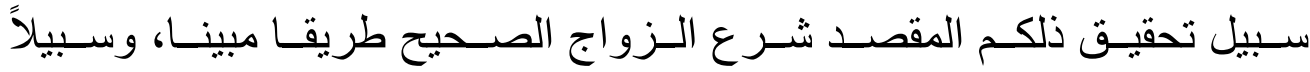

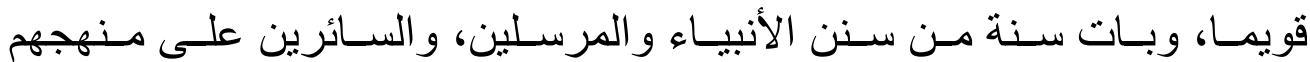

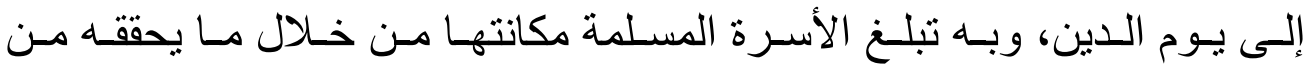

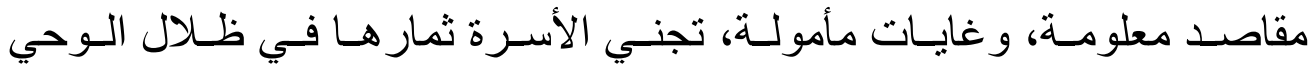

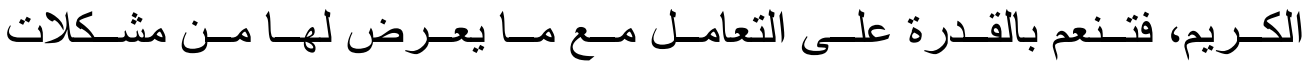

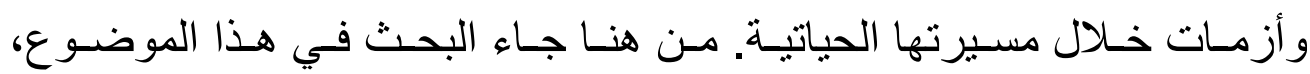

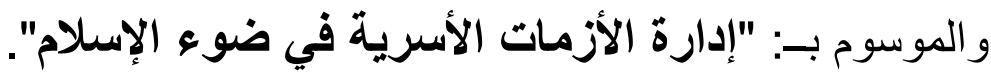

\section{والأي تتضح أهميته فيما يلي:}

- يعرض البحث لمنهج الإسلام في تحقيق الاستقرار الأسريّ من خلايل

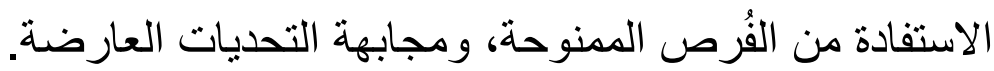

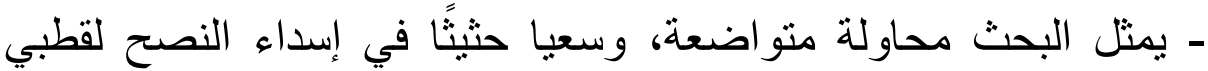

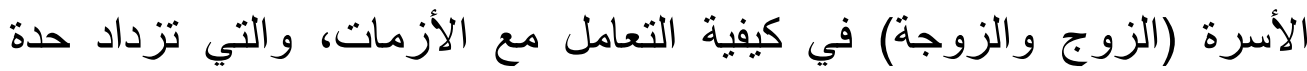

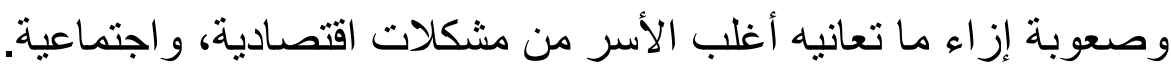
- يرصد البحث بعض الأزمات الأسرية، وكيفية إدارنها، في محاولة

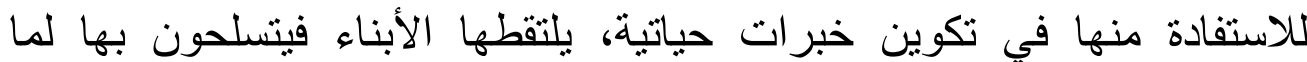
يستقبلون من حياتهم. 


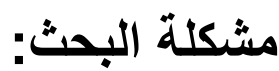

تتمحور مشكلة البحث حول الإجابة عن السؤال الرئيس: كيف يمكن إدارة

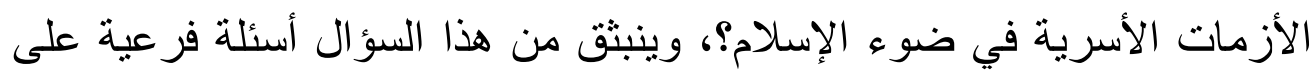

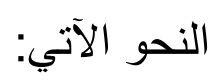

ـ ما أبرز فرص الاستقرار الأسري؟

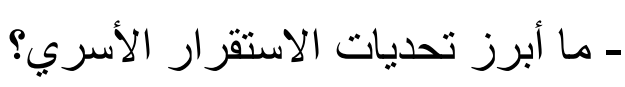

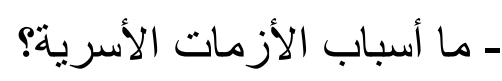
ـ - ما خصائص مدير الأزمات الأسرية.

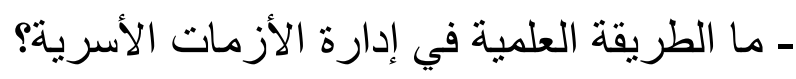
أهداف البحث:

ـ الكثف عن أبرز الفُرص التي يمكن الاستفادة منها في تحقيق الاستقرار الأسري.

- إبر از بعض تحديات الاستقرار الأسري، والتي قد تنتج أزمات أسرية. ـ الإبانة عن الأسباب الداخلية والخارجية للأزمات الأسرية. ـ - توضيح أبرز خصائص وسمات مدير الأزمة الأسرية. - بيان الأسلوب العلمي في إدارة الأزمات الأسرية.

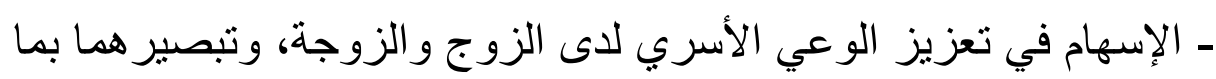

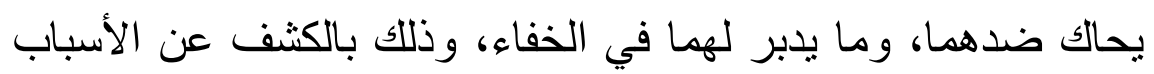

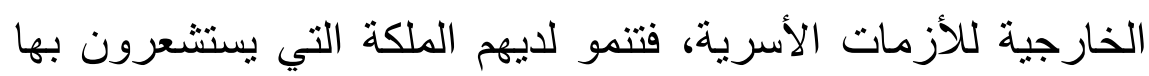

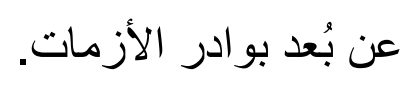

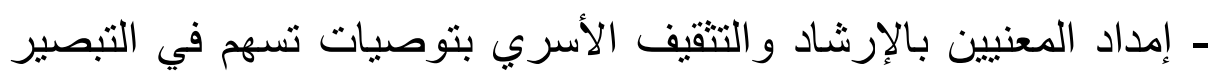

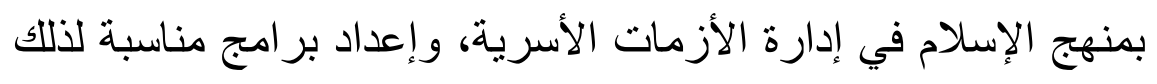

$$
\text { وفق ما يعرض لهم من حالات. }
$$

\section{الحدود الموضوعية:}

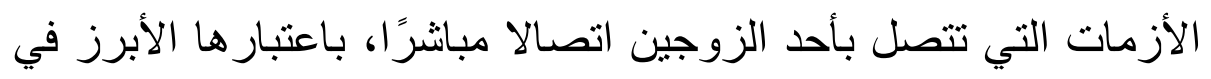
المنظومة الأسرية، و التي يتعدى أثر ها باقي أفر ادها. 
- O

$$
\text { منهج البحث: }
$$

استخدم الباحث المنهج الاستقرائي الذي يُعنى بالنظر في المعلومات

الجزئية لإعطاء مبادئ عامة كلية.

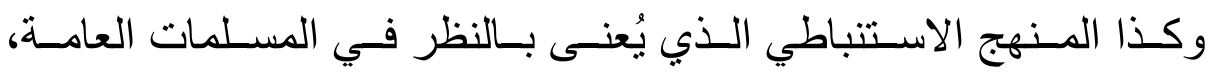

لاستخلاص مبادئ خاصة.

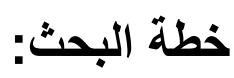

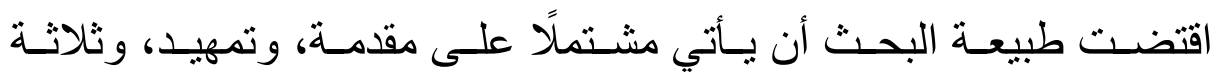

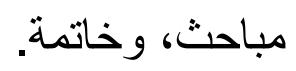

المقدمة، وحوت: أهميـة البحث، مشكلة البحث، أهداف البحث، الحدود

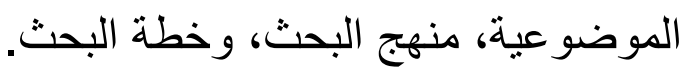

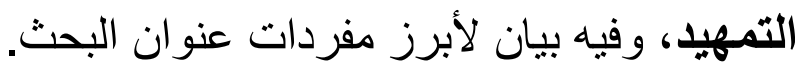

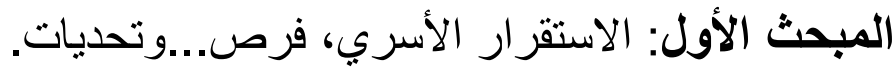

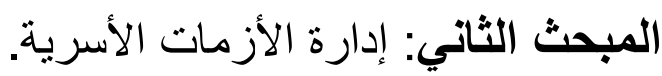

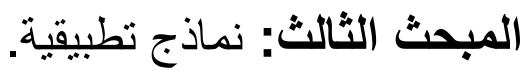

خاتمة، وبها أهم نتائج وتوصيات البه نطبة، البحث.

$$
\text { فهرس الموضور البحث. }
$$

د. محمد أحمد محمد الاش 


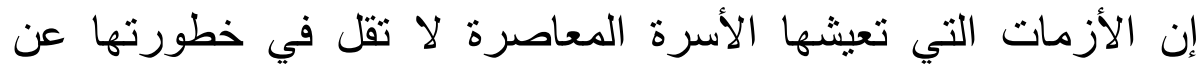

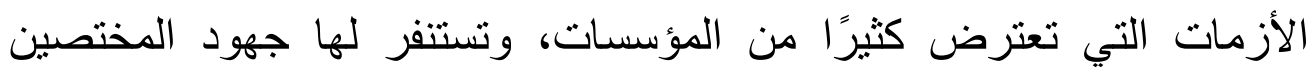

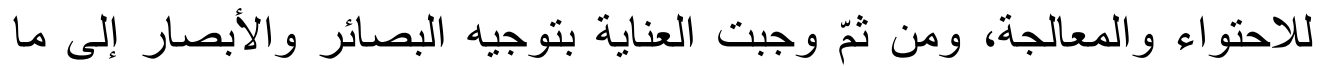

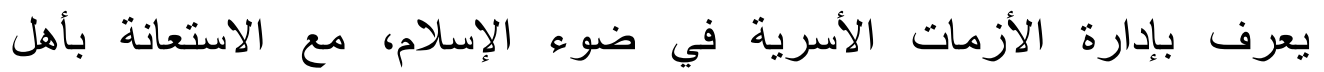

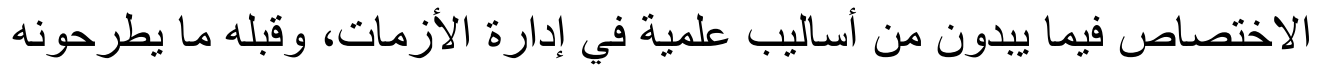

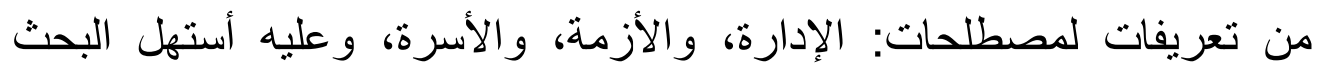
بييان مفر ادات عنو انه على النحو الآتي:

\section{أولًا: تعريف الإدارة في اللغة الإنة والاصطيلاح}

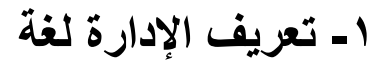

يأتي لفظ الإدارة ليدل في بعض الادرة لفعة فعانيه على الإلزام بالأمر فعلاً أو تركاً،

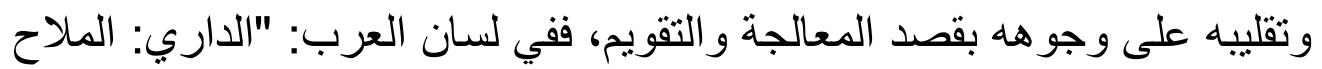

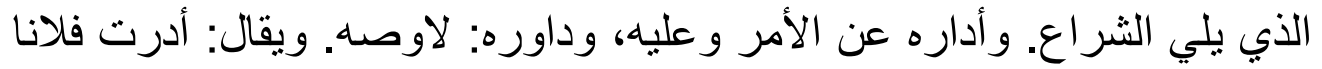

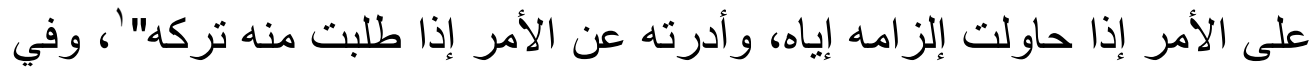

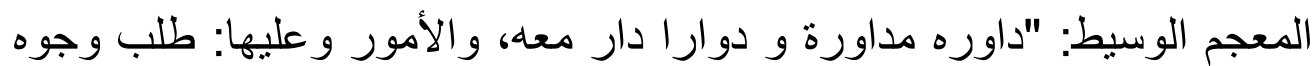

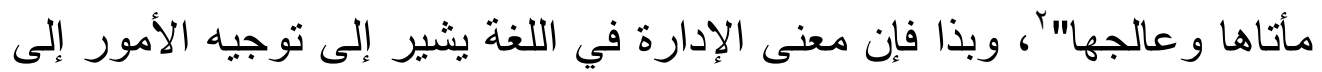

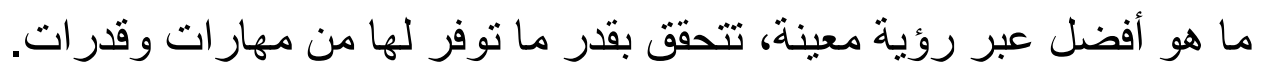

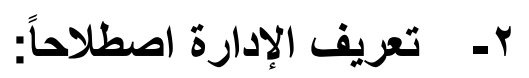

تعرف الإدارة بأنها: (النشاط الإنساني الذهني الاجتماعي المستمر الذي والإني

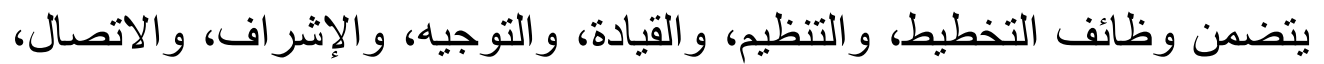

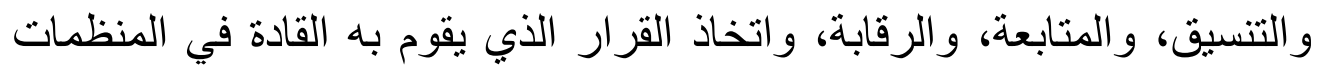

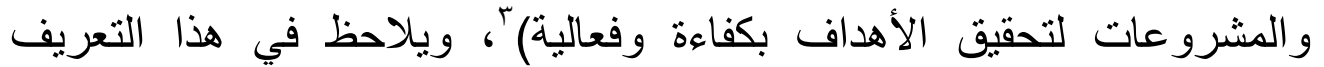

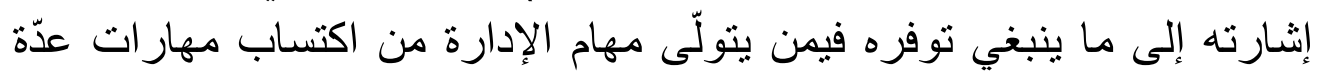

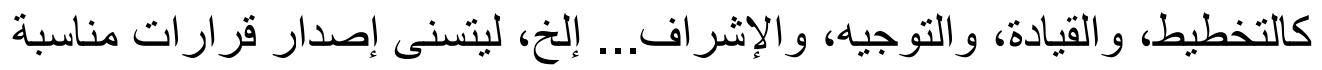

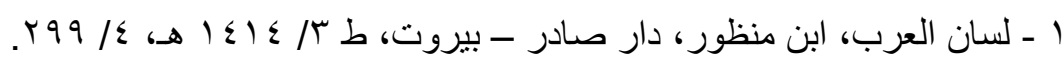

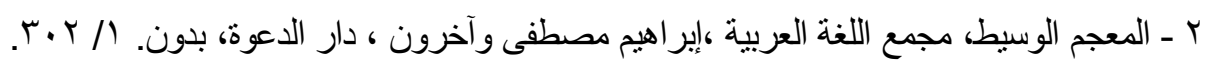

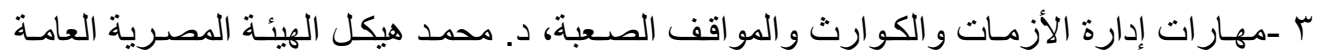

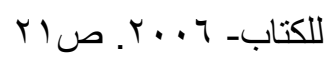


تسهم بفاعلية في تحقيق الأهداف المنشودة، ولا يبعد ذلك عما يجب توفره فيمن

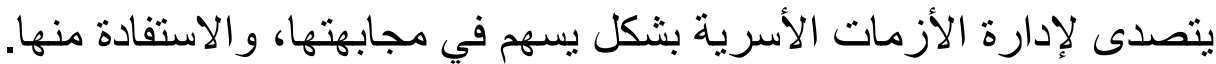

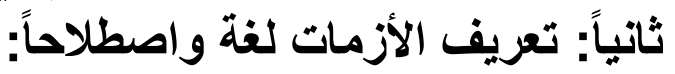

\section{ا- - تعريف الأزمة في اللغة}

يشير لفظ الأزمة في اللغة إلى الضيق، وصعوبة واشتداد الأشياء بعد الثداء

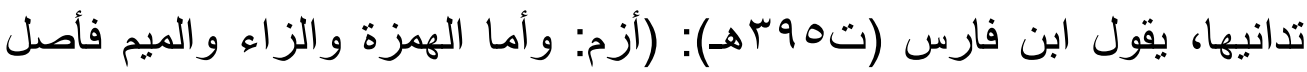

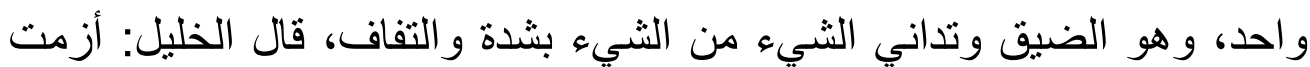

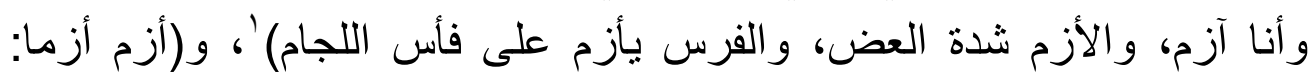

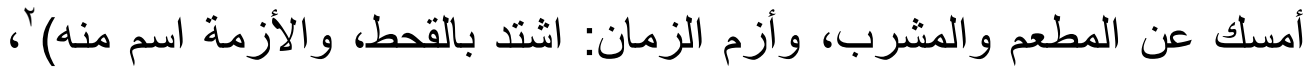

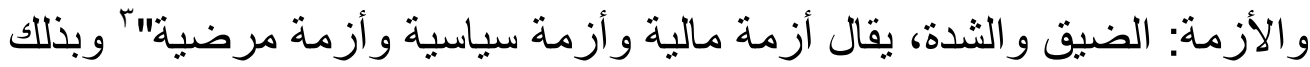

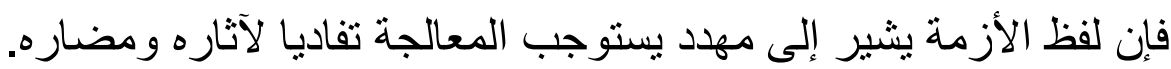
r- ت بعريف الأزمة اصطلاحاً:

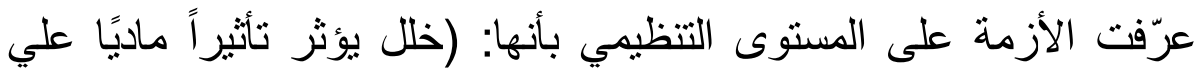
النظام كله - نظام المنظمة ـ كأزمة تهدد العناصر الأساسية الرئيسة التي يقوم عليها هذا النظام، ومن ثمّ يجب نوافر شرطين علي الأقل : - حدوث خلل ذا تأثثر شديد

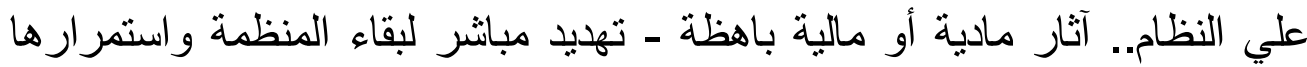

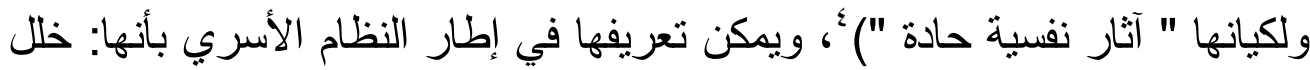
مفاجئ معقد يكتنفه الغوض، بهدد النظام الأسريّ بثكل سريع، ينتج حلقات منباينة من المواقف الحادة، ذات تأثثر بالغ على استقر اره وبقائه. ثالثثاً: مفهوم إدارة الأزمات

حتمًا تسترعي الأزمات انتباه أطر افها للوقوف على دوات دواعيها، ومحاولة التخلب عليها، و التقليل - قدر الاستطاعة ـ من آثار ها المادية و المعنوية، وقد

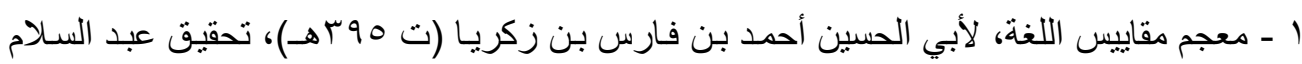

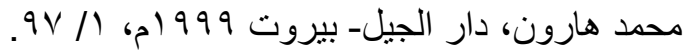

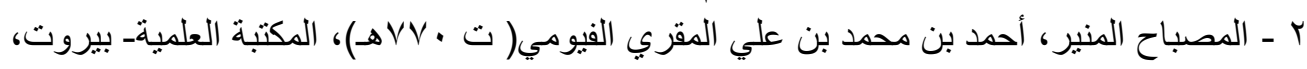
.1 111

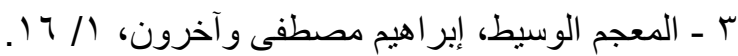

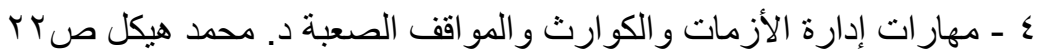


- ○人今_

يكون من حُسن إدارة الأزمة، والتعامل معها أن تتو افر القدرة الكاشفة لأبعاد الأزمة عبر إثشارات وتتبيهات، وفي هذا الإطار تعرف إن إدارة الأزمات

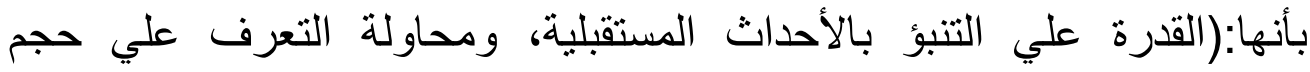
وطبيعة الأزمات المحتملة، وكافة البدائل المتاحة لمنع وقوع الأزمات، أو أو التقليل من حدة آثار ها، و الإعداد لمواجهتها عند حدوثها)'، وتعني في النظام الأسري:

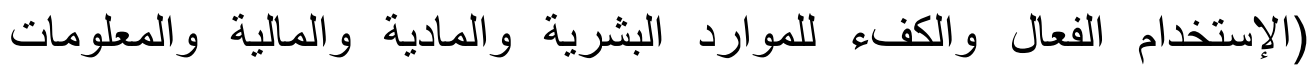
والأفكار والوقت لربة الأسرة بالتعاون مع أفرادها من خلال العمليات الإدارية

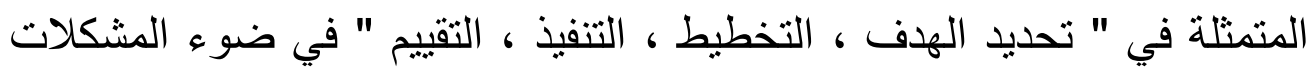

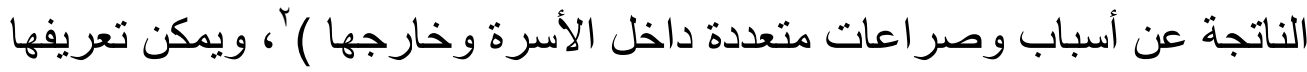
كذلك بأنها: القدرة على التعامل الإيجابي مع الخلل المفاجئ الذي بمثل تهديدًا

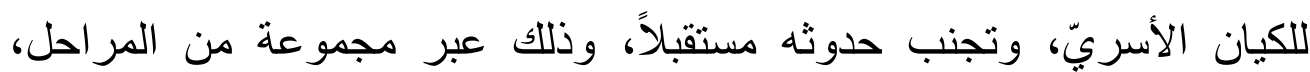

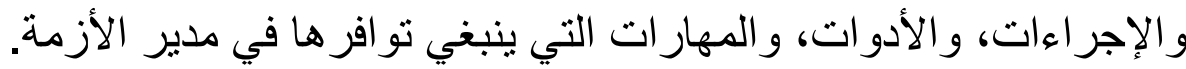

\section{رابعاً: الأسرة في اللغة والاصطلاح}

\section{ا - تعريف الأسرة لغة:}

تأتي مادة " أسر " في اللغة لتدل على: القوة والإحكام، ومايُشند به، ويرُكن إليه، و(الإسار بالكسر: مصدر أسرته أسرا و إسارا، وهو أيضًا الحبل والأل

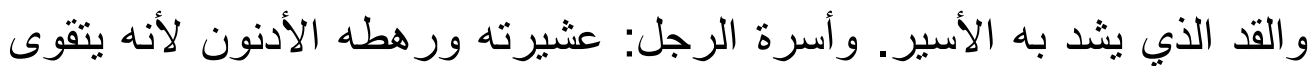

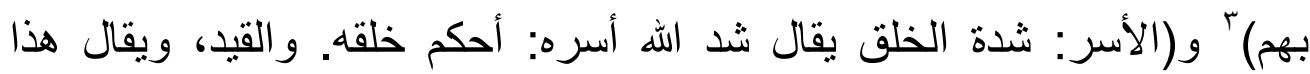

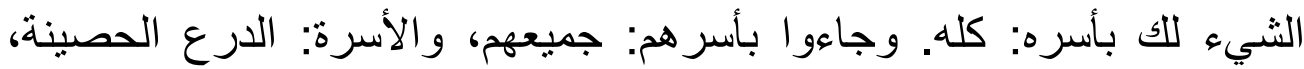

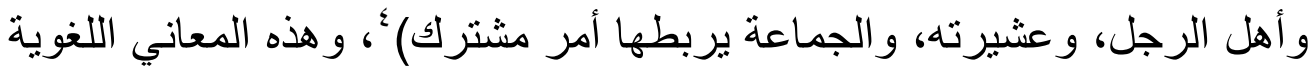

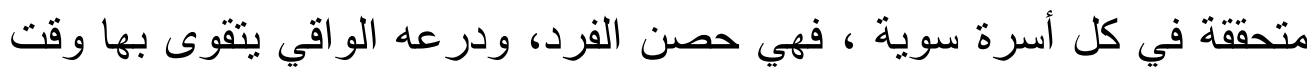

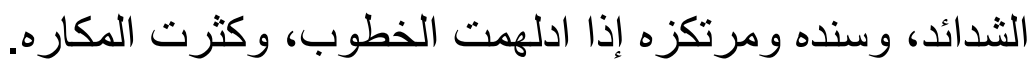

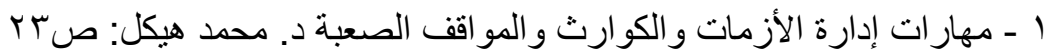

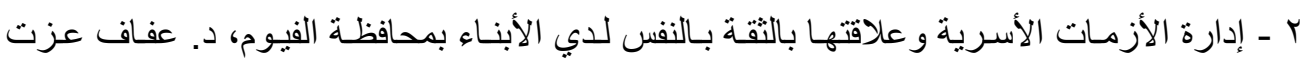

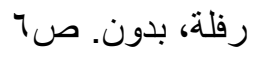

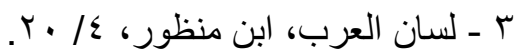

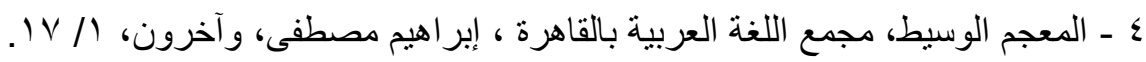


يعرّف علماء الاجتماع الأسرة بأنها: (جماعة اجتماعية أساسية ودائمة ونظام

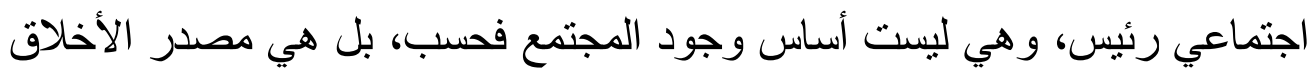

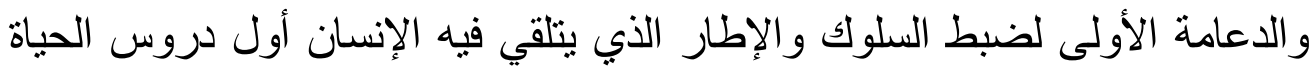

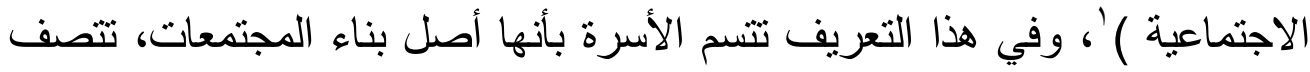

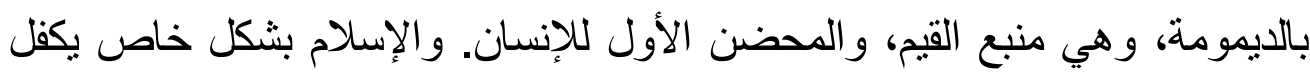

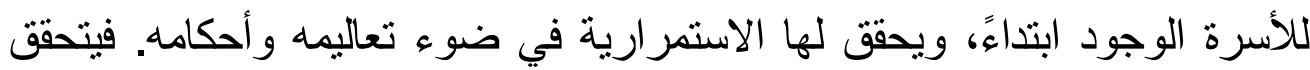

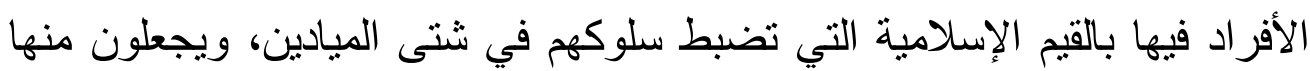

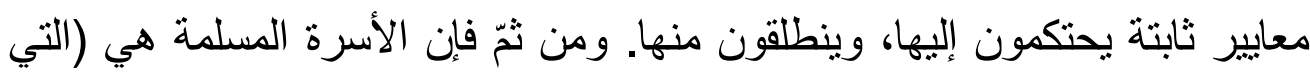
تحقق في ركنيها الأساسيين - الزوج والزوجة - أهداف التربية الإسلامية والقادرة

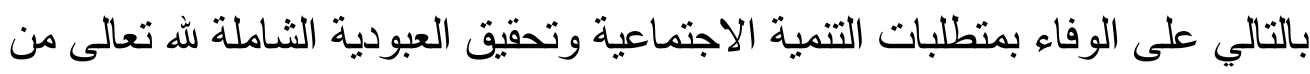

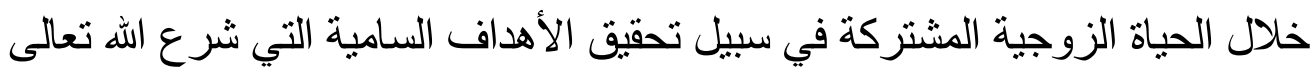

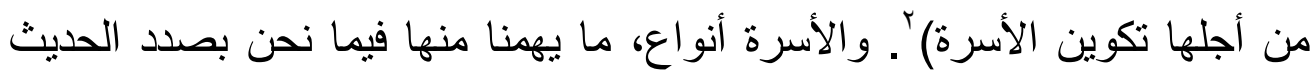

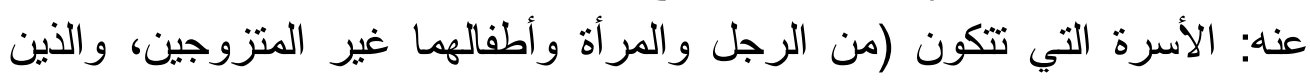

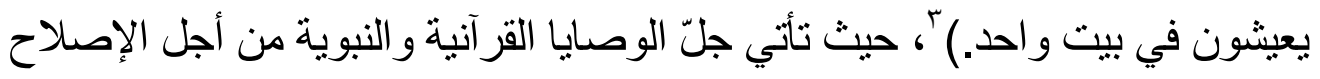

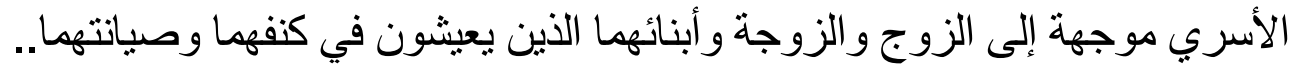

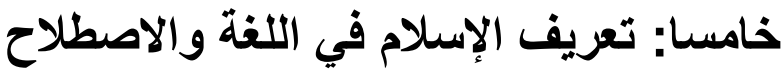

\section{ا ـ تعريف الإسلام في اللغة:}

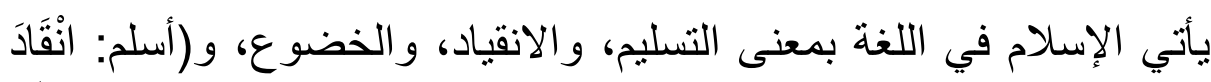

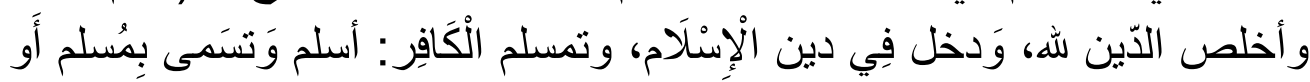

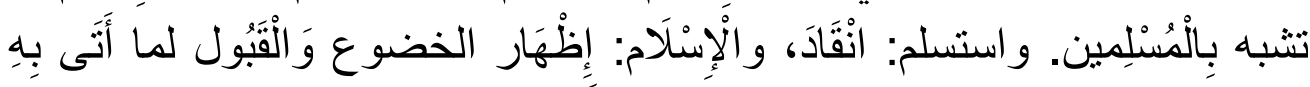

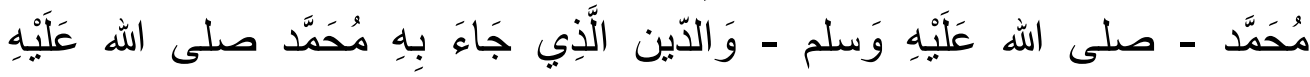

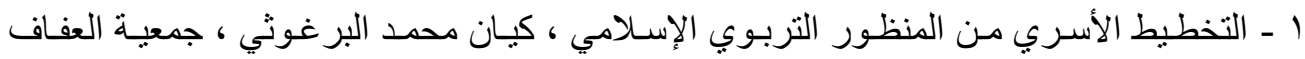

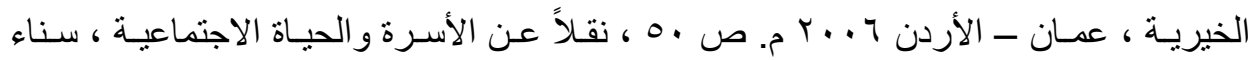

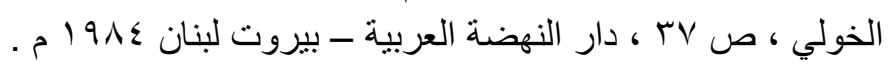

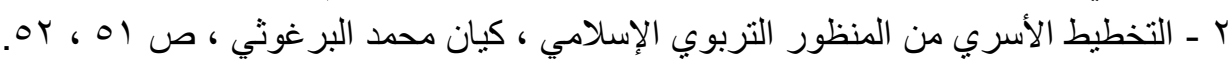

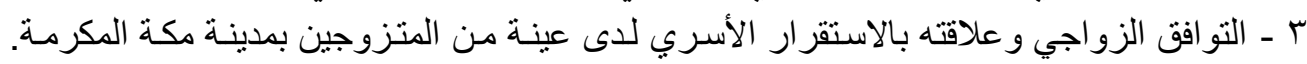




$$
\text { -09.- }
$$

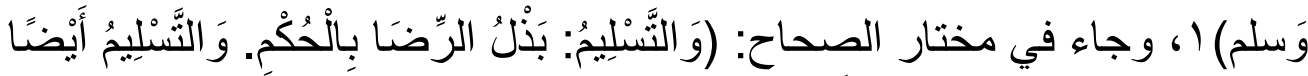

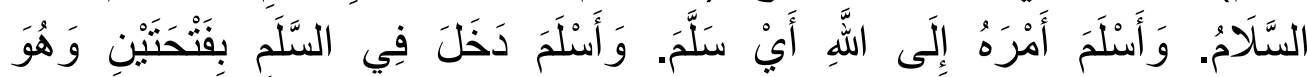

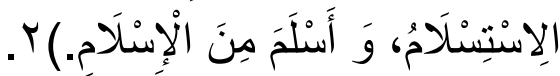

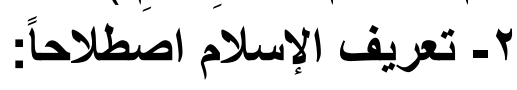

يُقصد بالإسلام في هذا البحث الدين الخاتم بما حواه من شرائع وأحكام وتعاليم، ترسم للبشرية طريقها الواضح الذي يحقق لها السعادة في العاجل

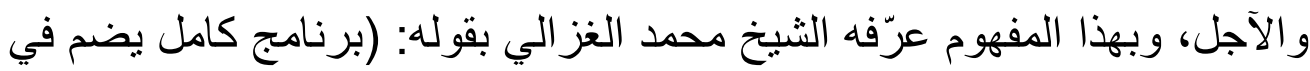
أطوائه جميع المعارف التي يحتاج إليها الناس ليبصروا الغاية من محياهم،

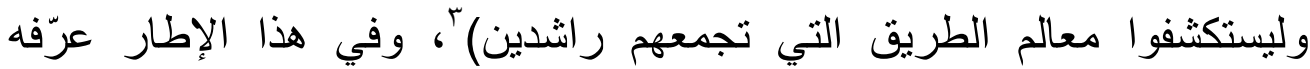

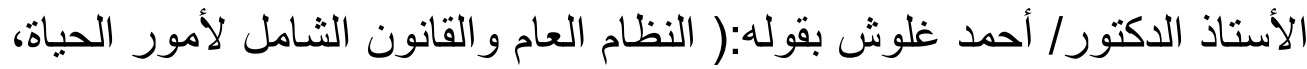

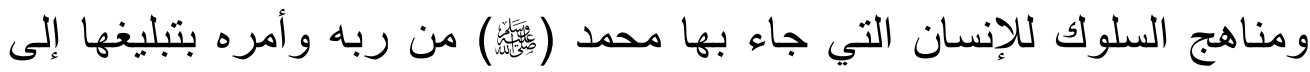

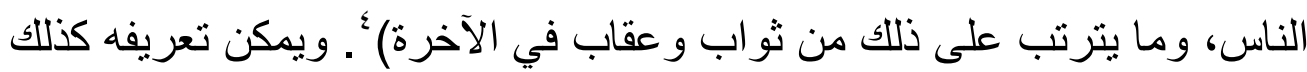

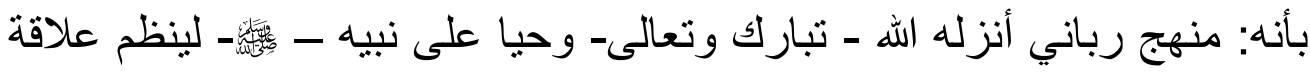

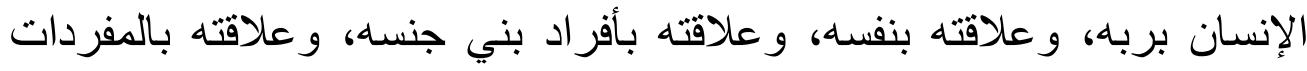

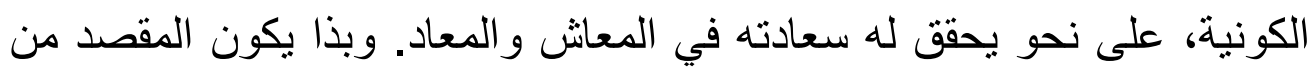
عنوان البحث: التعرف على كيفية إدارة الأزمات الأسرية، اعتماد على مانى ما جاء في الإسلام من شر ائع وتعاليم وأحكام.

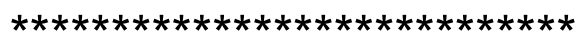

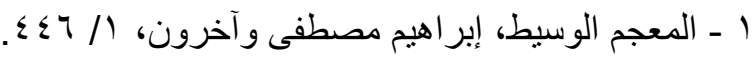

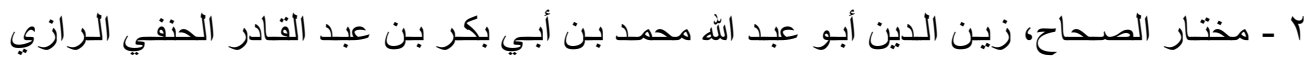

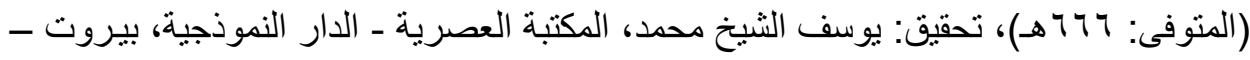

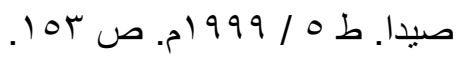

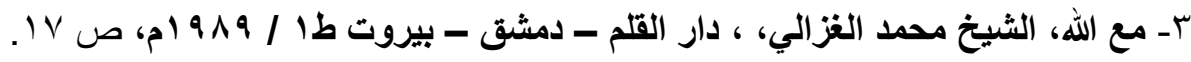

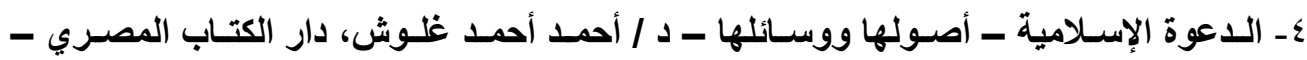




\section{المبحث الأول}

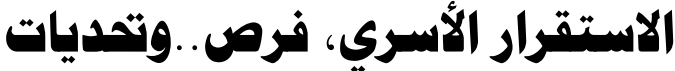

عني الإسلام بالاستقرار الأسري عناية بالغة، لأثره البيّن، وانعكاسه الواضيح

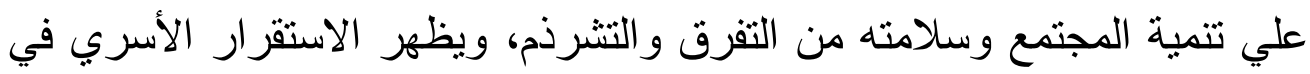
كونه (نظاما تتحدد فيه الأدوار، وتتغير بتغير مراحل النمو التي يعيثها أفراد

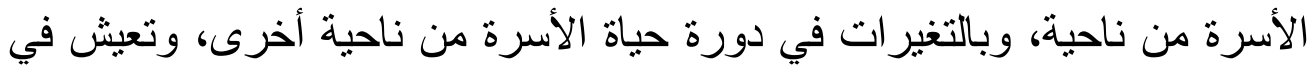

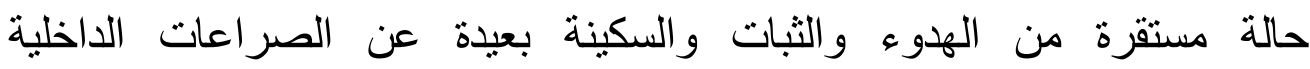

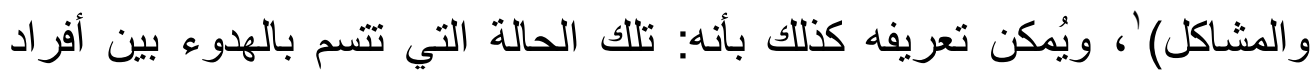
الأسرة، تعلو فيها قيمة التعاون على تخطي صعاب الحياة ومشكلاتها، وقيام كل فرد بدوره المنوط به في كل مرحلة حياتية، ولذلك أثره في إيجاد (العلاقة الأسرية الناجحة التي تقوم على التفاعل الدائم بين أفراد الأسرة جميعًا، والتي تهيهئ للأبناء

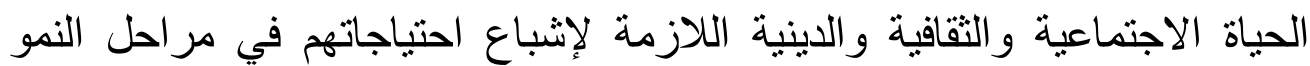

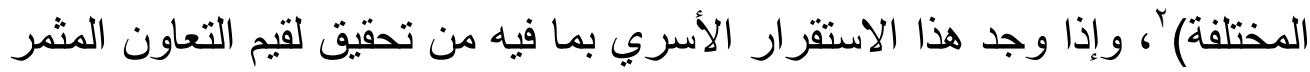

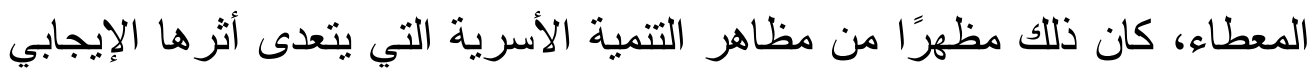

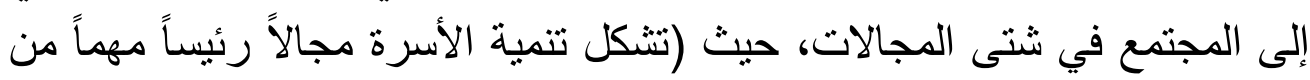

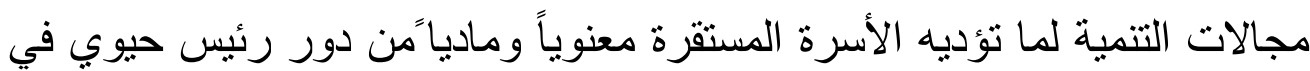
بناء المجتمع المتماسك المستقر؛ وهي تمثل وحدة بناء التصادية واجتماعية ثقافية

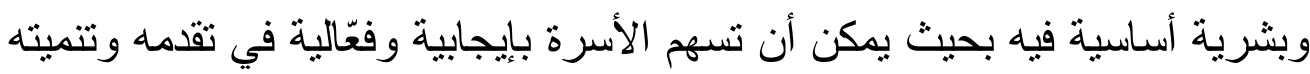
في مقابل ما قد تستنزفه الأسر غير المستقرة والمفككة من موارد المجتمع وطاقاته

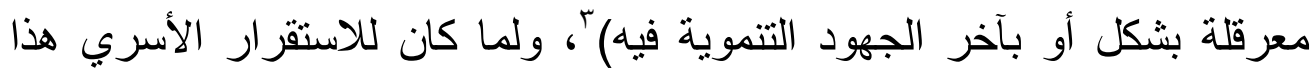

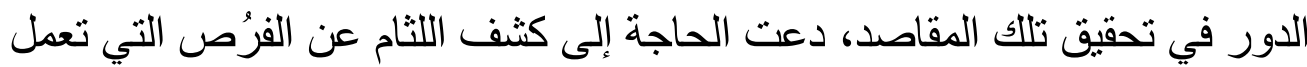
على تحقيقه، وكذا التحديات التي تُعد مكمنا للأزمات الضاربة للإستقر ار الأسري،

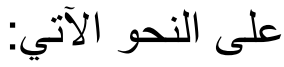

1 ـ معالم الاستقرار الأسرب ومقوماته، د. مفتاح علي حسين بالحاج.مجلة كليـة الآداب - مصر اته.

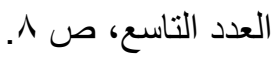

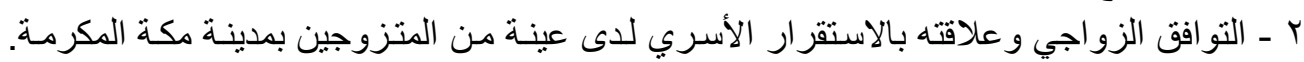

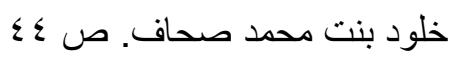

ץ ـ التخطيط الأسري من المنظور التربوي الإسلامي، كيان محمد البرغوثي ، ص ع؟ . . 
المطلب الأول

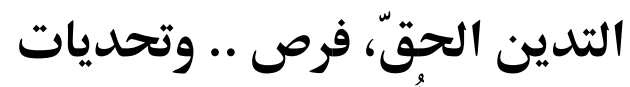

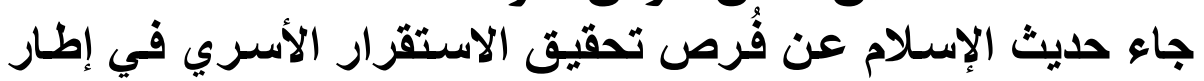

التدين الحقّ على التحو الآتي:

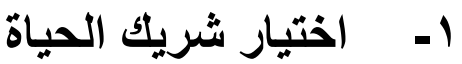

مرحلة تأسيس الأسرة هي أهم مرحلة تدعم الاستقرار الأسري بكافة

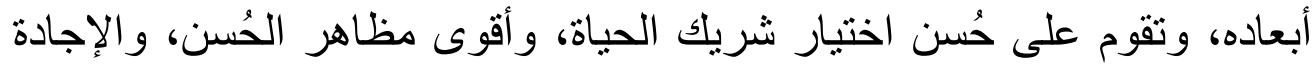

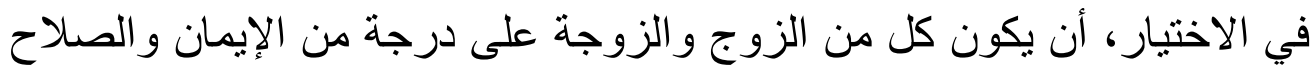

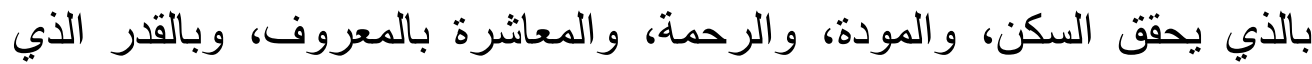

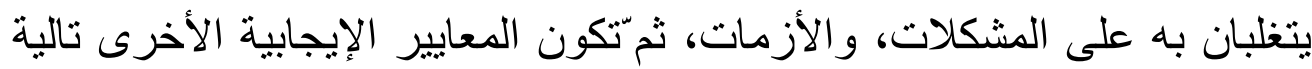

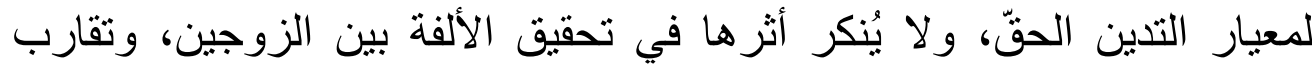

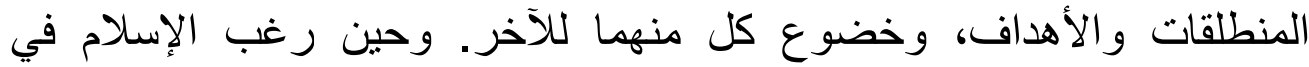

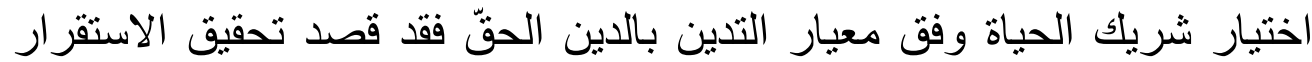

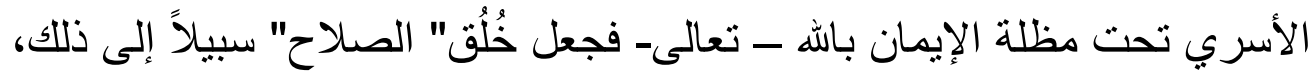

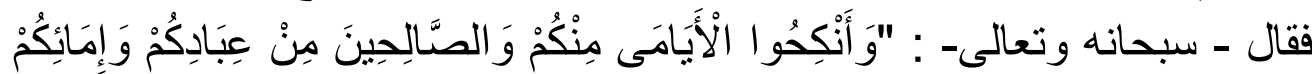

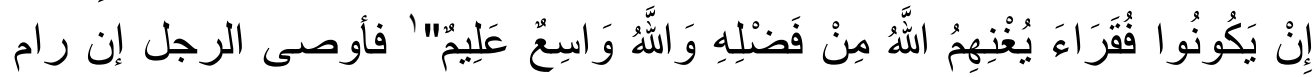

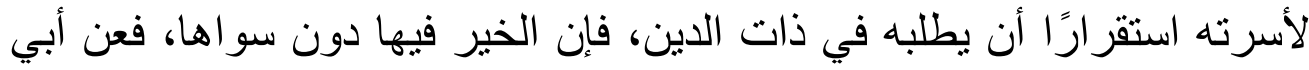

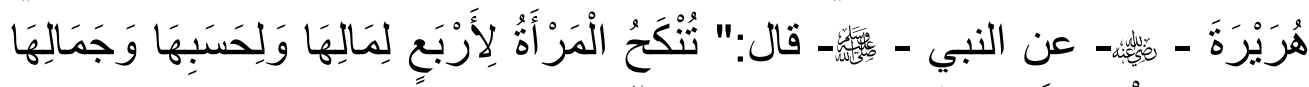

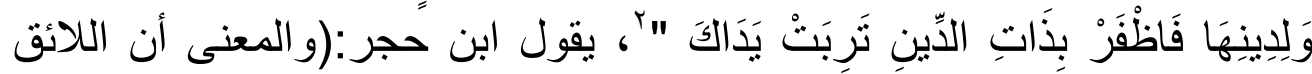
بذي الدين والمروءة أن يكون الدين مطمح نظره في كل شيء لانيا لا سيما فيما

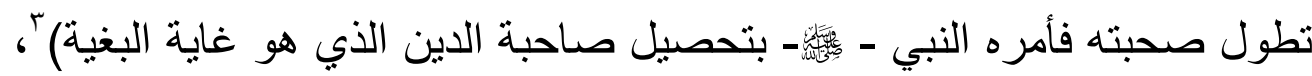

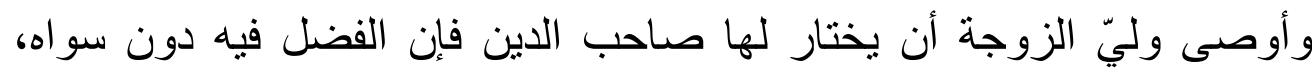

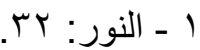

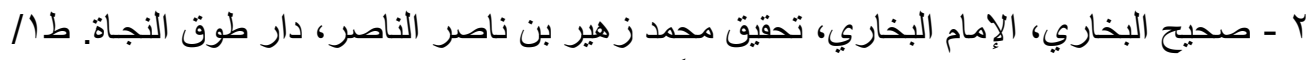

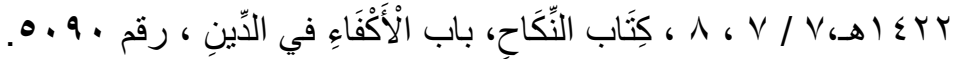

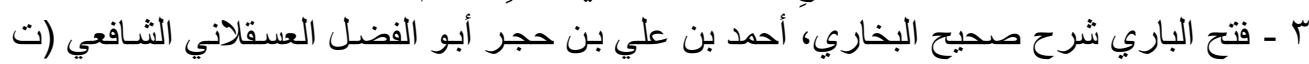

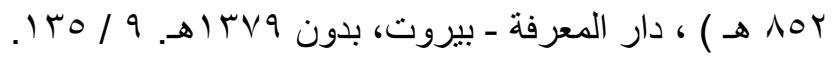


يقول المناوي:( يعني أنكم إن لم ترغبوا في الخلق الحسن والدين المرضي الموجبين للصلاح والاستقامة ورغبتم في مجرد المال الجالب للطغيان الجار

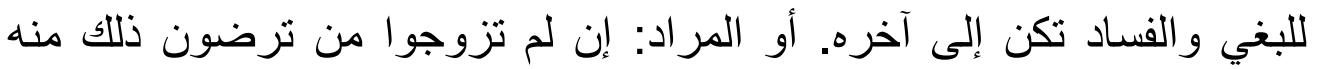

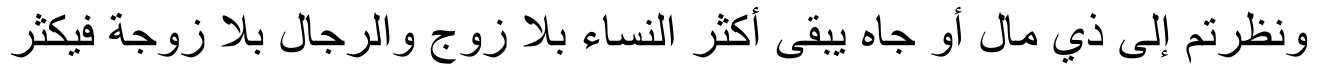

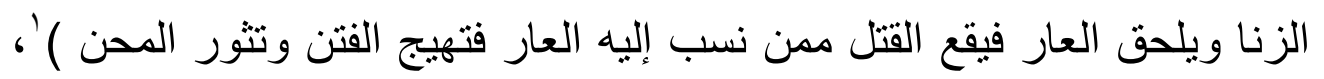

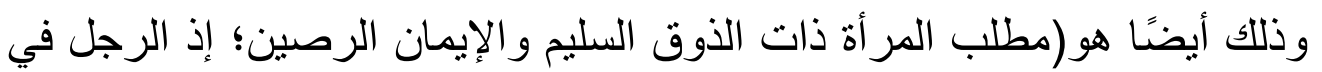

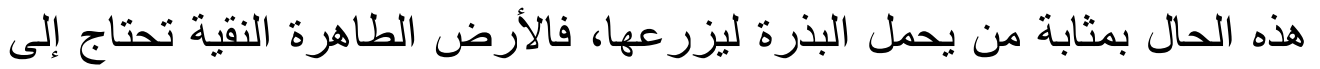

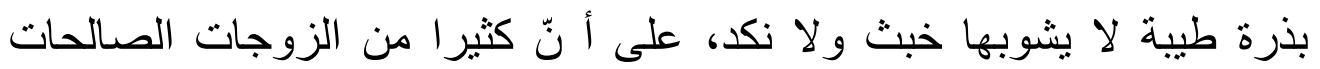

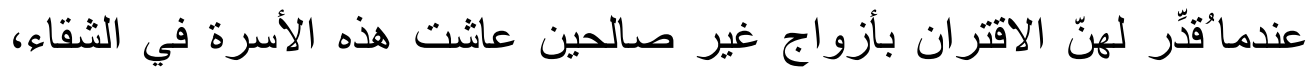

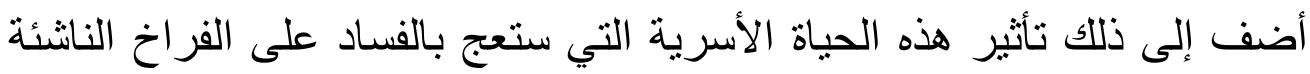
في هذ البيت..إنها فتنة الدين التي لا بنجو منها إلا ذو إيمان عظيم، فالمرأة الأ -

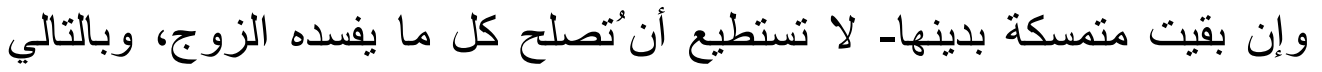

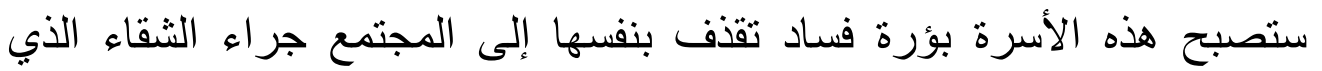
تكابده.)'، فهذا المبنى (الأسرة) المؤسس على فلى دعامة الدين الحق، لاشتك يتمتع

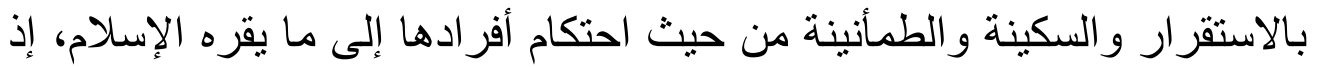

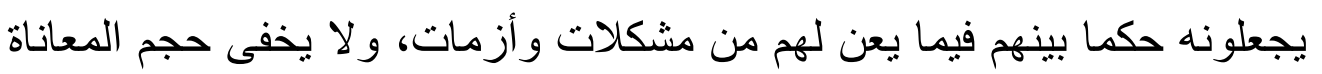

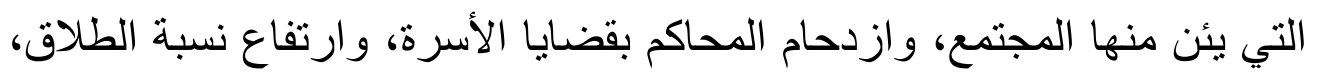

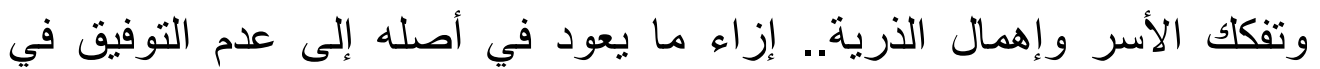

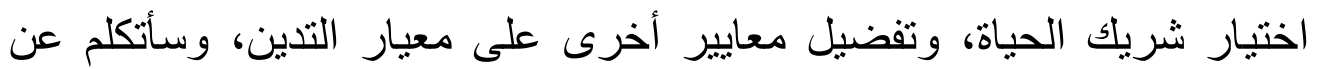
ذللك بشيء من التفصيل عند الحديث عن تعزيز القيم الإيمانية، وأثرها في في ولئي الاستقرار الأسريّ.

\section{r - التواصي بأداء الواجبات الاينية}

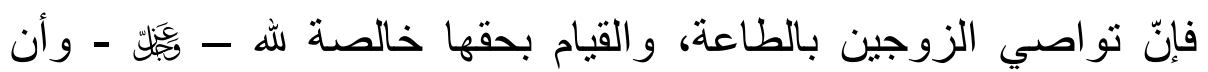

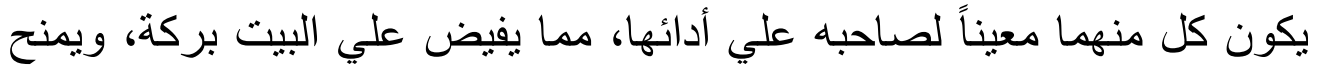

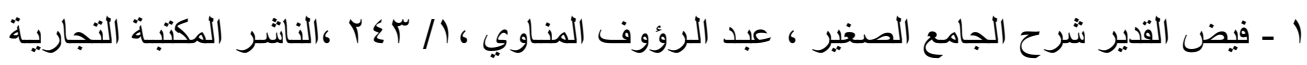

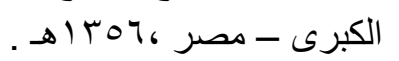

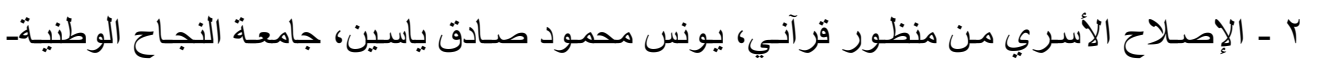

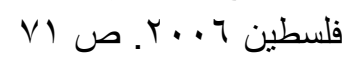


الأسرة هدوءًا واستقرارًا، ففي سنن أبي داود من حديث أبي هريرة قال: قال

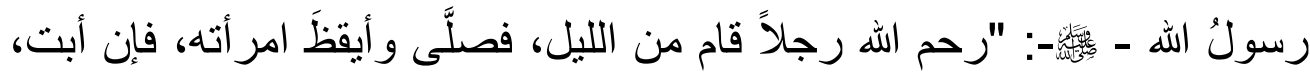

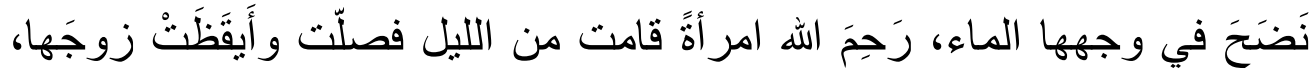
فإن أبَى نَضَحَتْ في وجهه الماء"'، وفي هذا المنهج طريق القرب من الله -

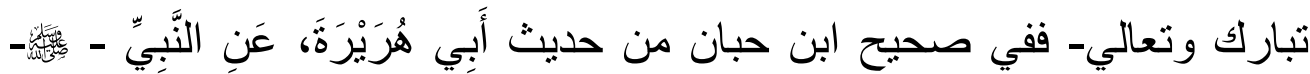

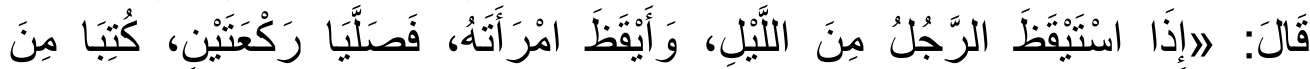

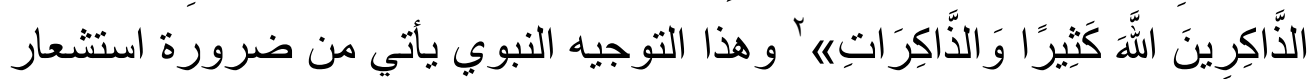

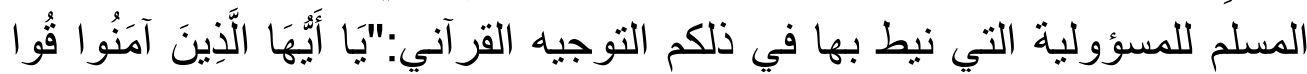

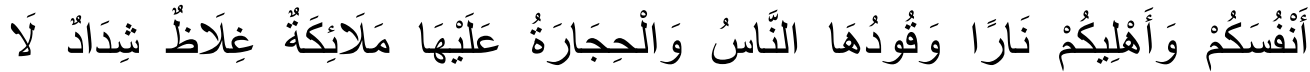

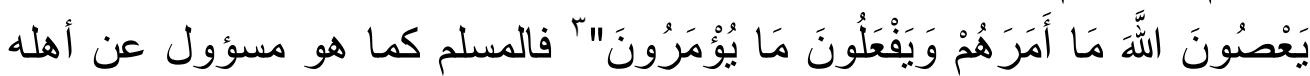

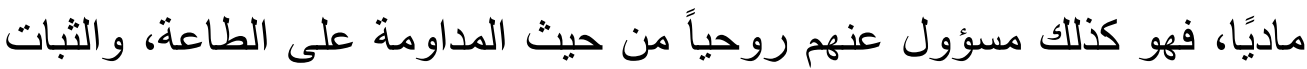

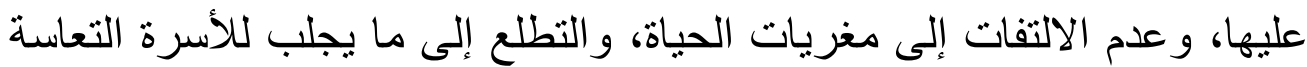
و الثقاء، فإن الأمر بالاصطبار على الصلاة كنموذج دال على الطاعة، يؤكد

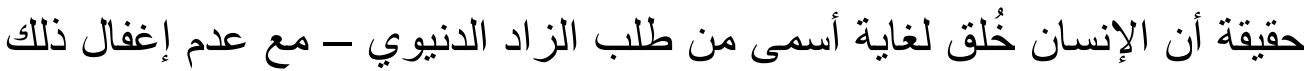

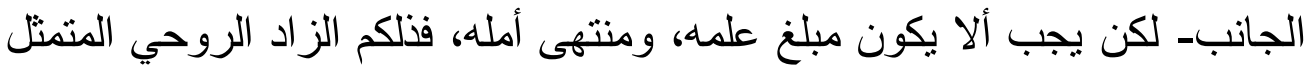

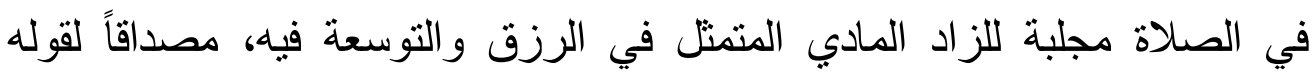

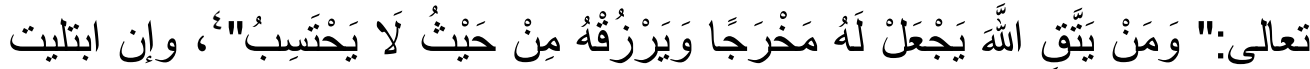
الأسرة بضيق الحال، أضاءت الطاعة جنبات حياتهم بقيمة الرضا بما قضى لهي الله به

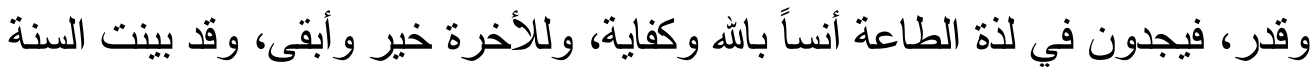

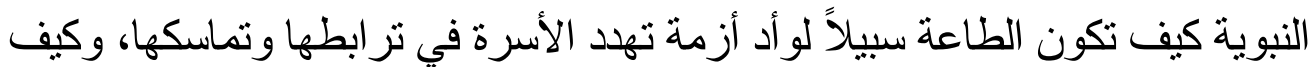
تكون الطاعة داعمة للاستقرار والاستمرار، حين تصبر المرأة المسلمة على ضيق

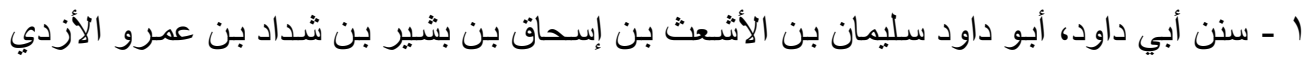

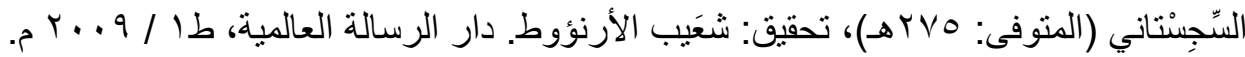

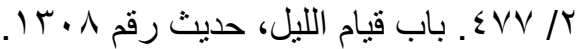

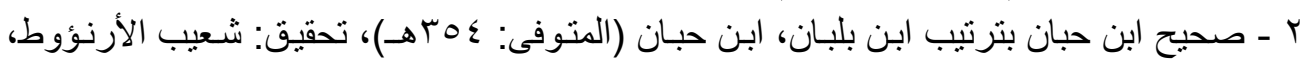

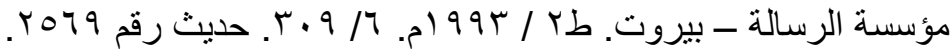


العيش، فتجد في الطاعة عوضا يزهد في الدنيا، ويرغب في الآخرة، ففي صحيح

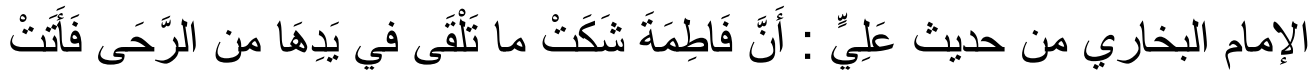

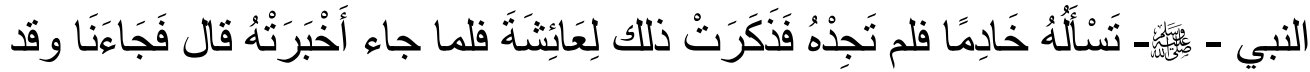

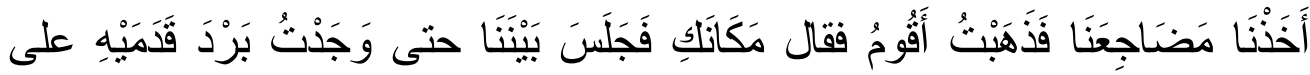

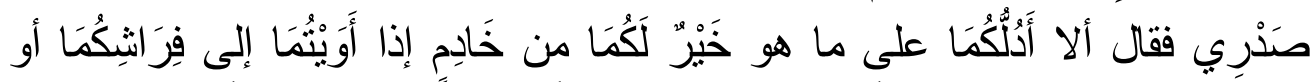

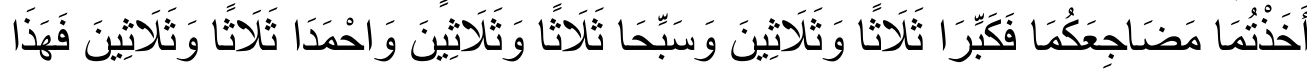

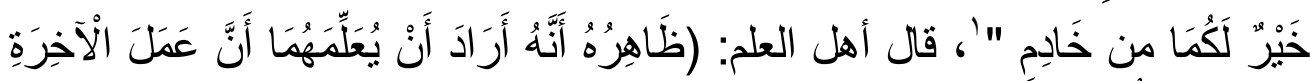

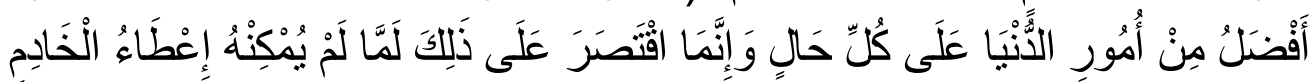

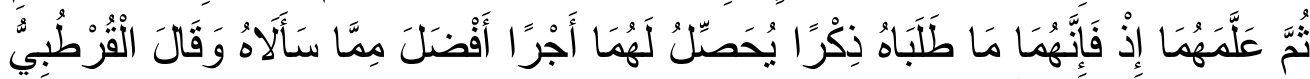

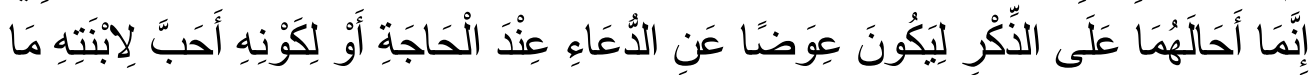

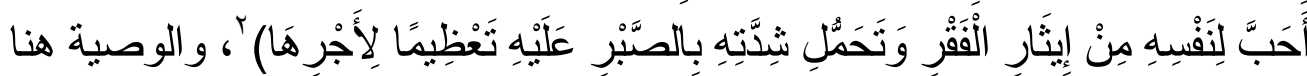

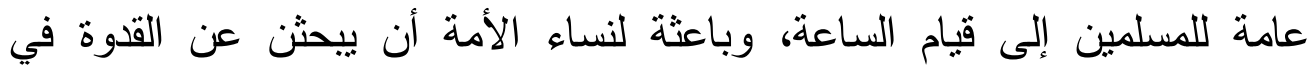
الصحابيات الجليلات، كيف أدرن حياتهن الأسرية باقتدار في ظلال الوحهي الوحي الإلهي.

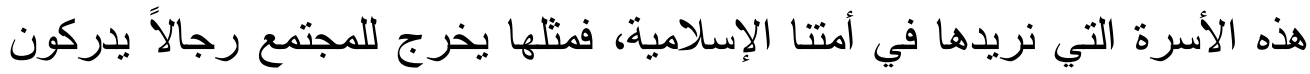

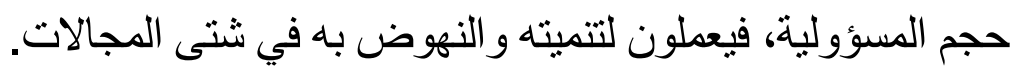

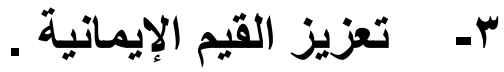

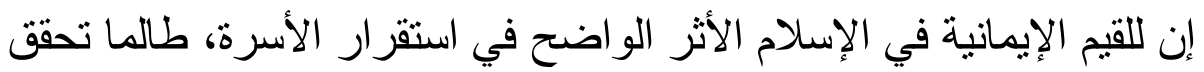

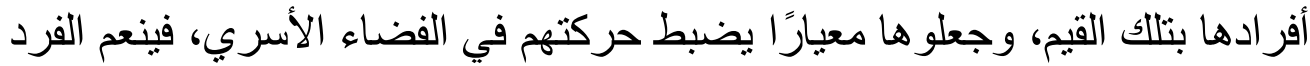

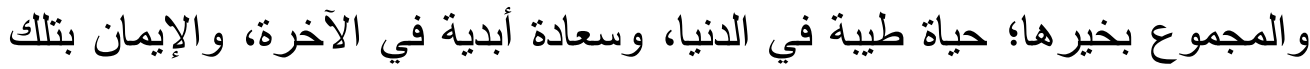
القيم باعث على العمل بما يستلزمه الاستقرار الأسري في كافة مناحي الحياة.

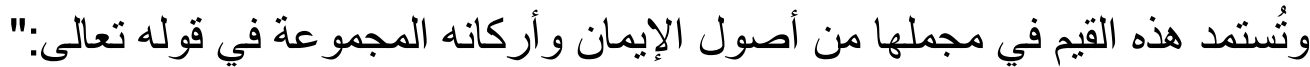

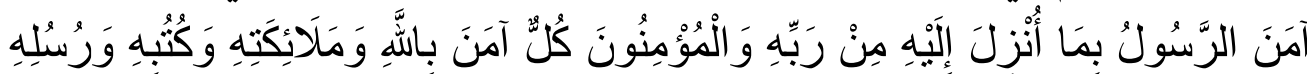

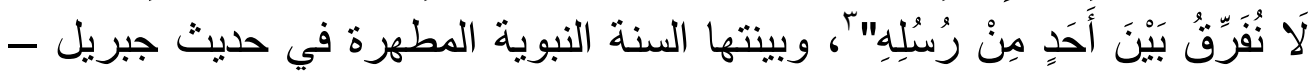

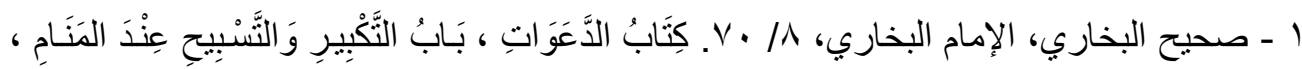

$$
\text { حديث رقم 1/ آبا. }
$$

r - فتح الباري شرح صحيح البخاري، أحدد بن علي بن حجر أبو الفضل العقلاني الثافعي، 1 ال، / 


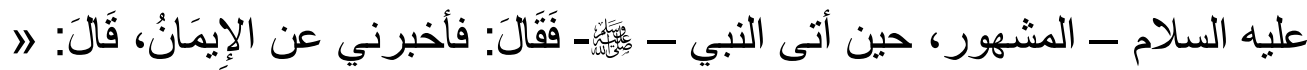

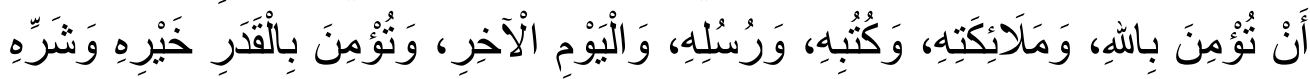

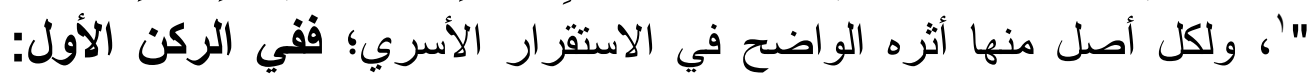

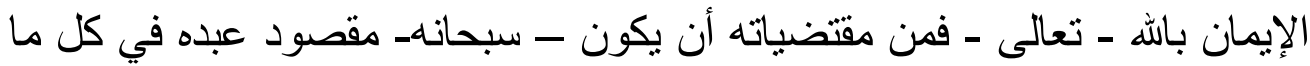

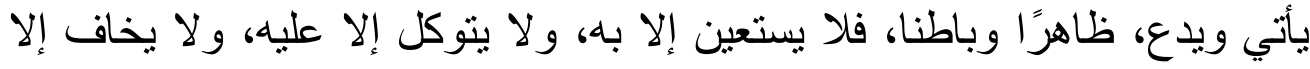

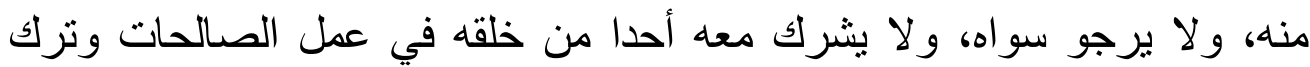

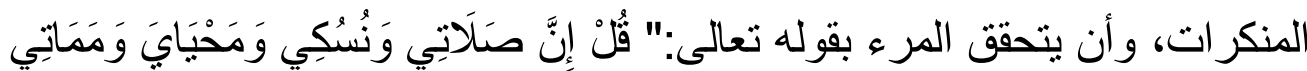

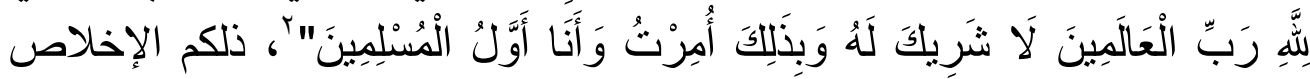

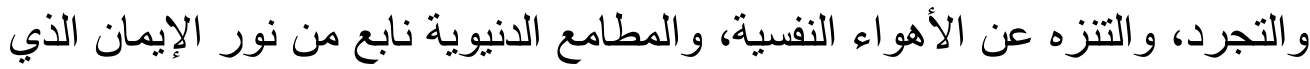

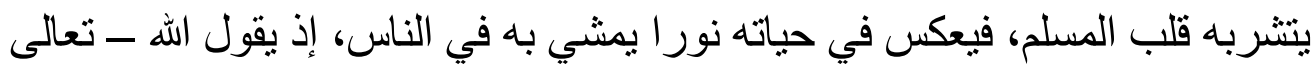

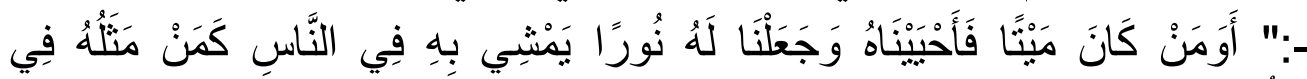

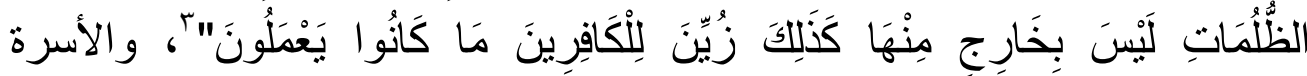

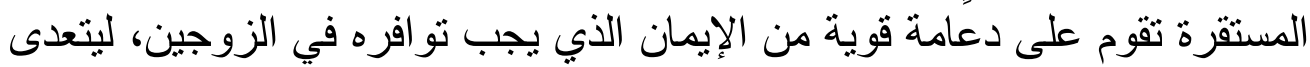

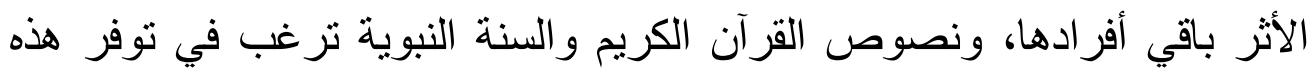
القيمة (الإيمان) و الذي يعبر عنه بالدين في كثير منها، ولما كانت الزوجة هي أم أم

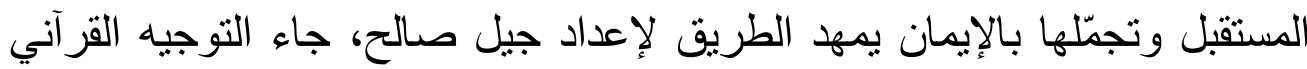

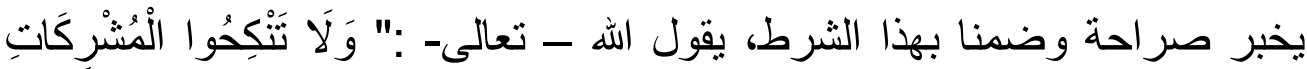

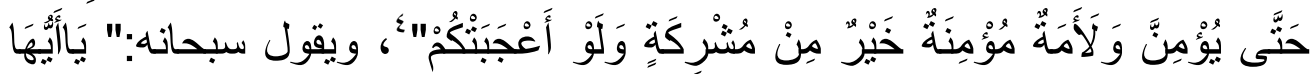

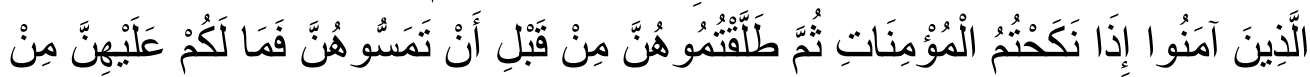

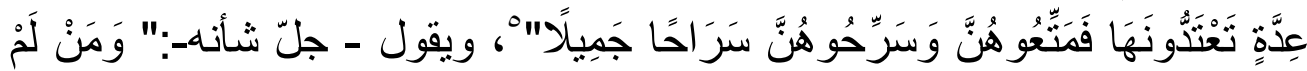

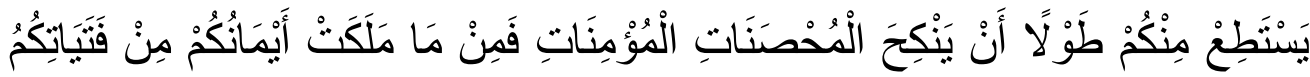

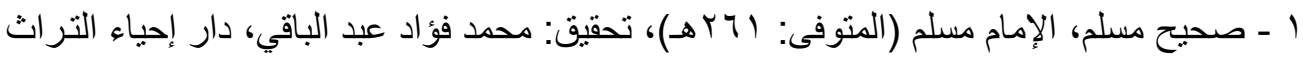

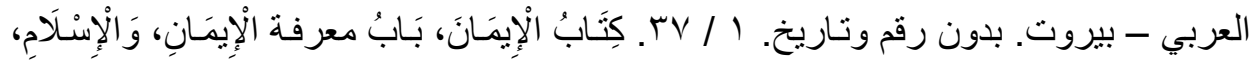

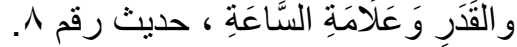

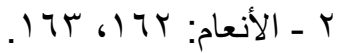

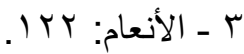

$$
\begin{aligned}
& \text { ع - البقرة: الانعام: الآبr }
\end{aligned}
$$

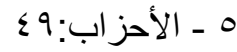




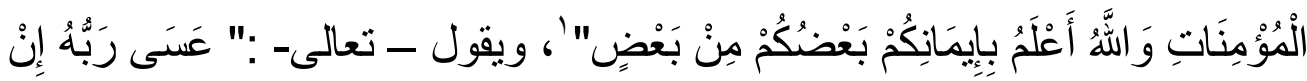

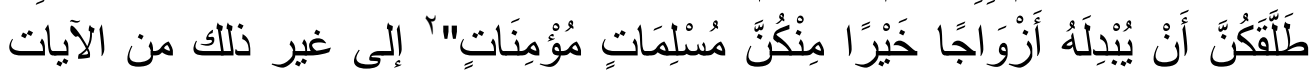

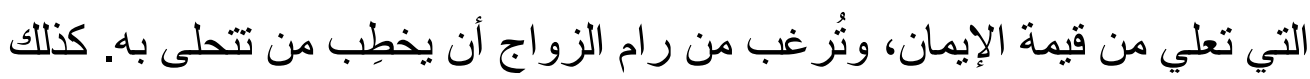

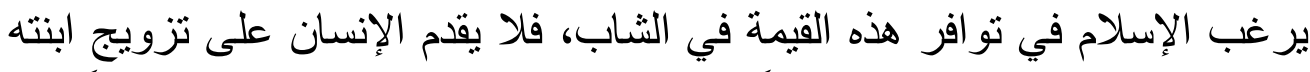

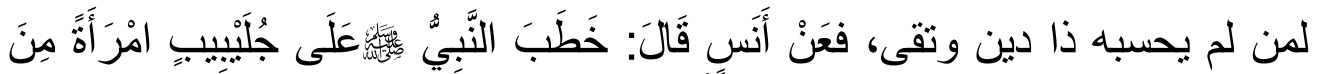

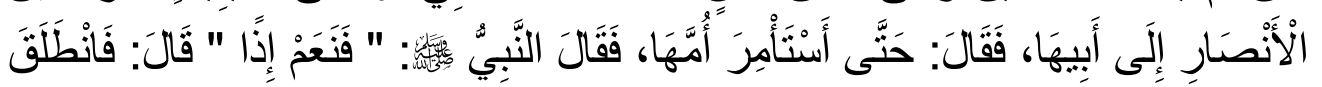

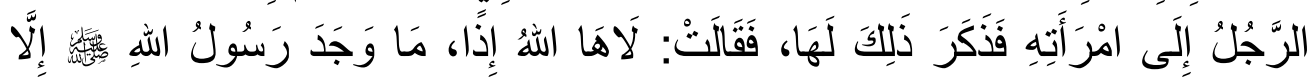

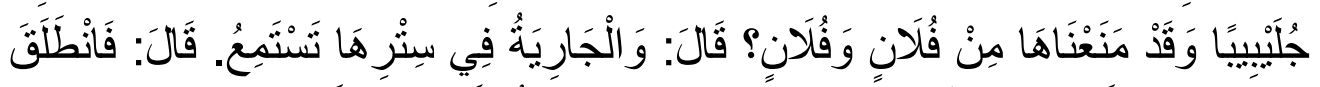

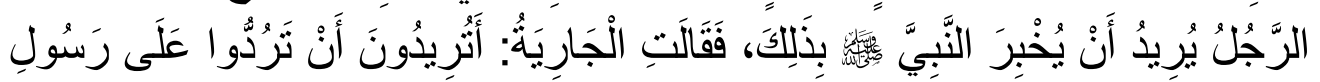

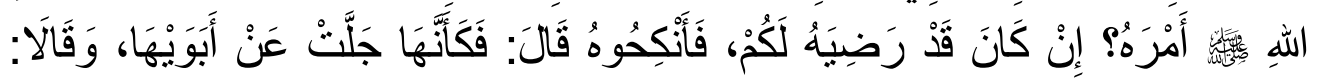

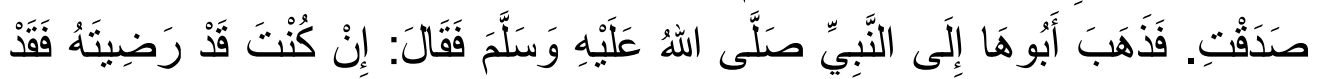

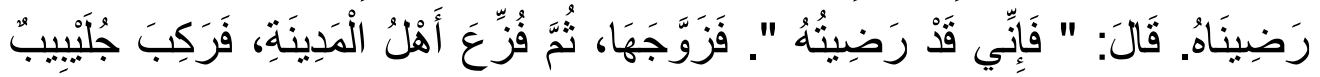

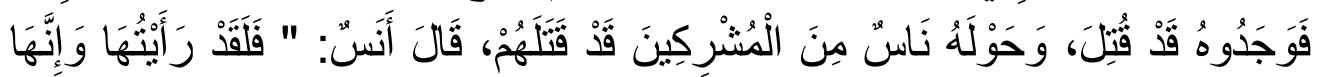

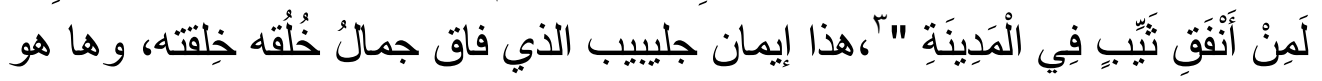

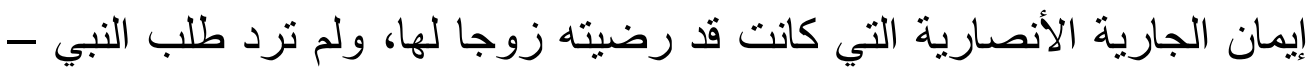

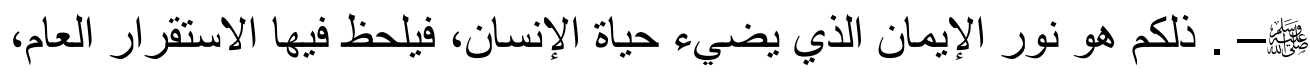
وفي أسرته بوجه خاص، فإذا حسنت صلة العبد بربه، تحقق له الاستقرار في حياته الإنهان الإنها

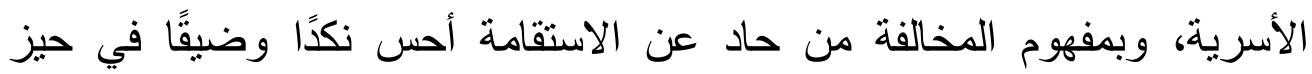

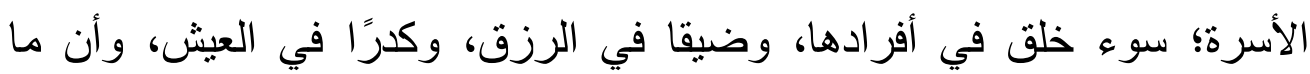

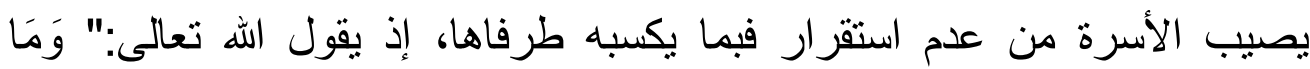

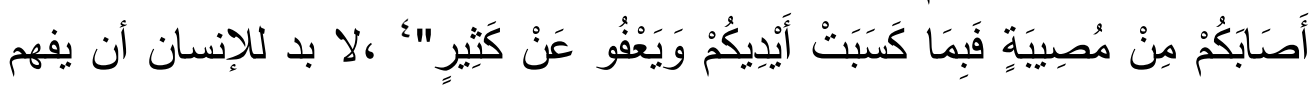

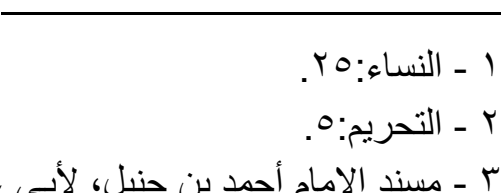

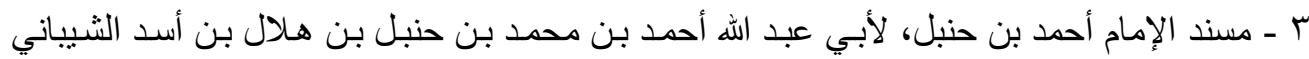

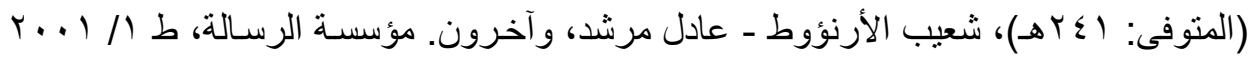

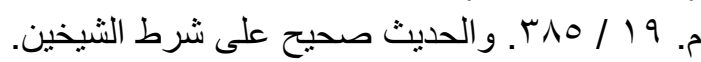




$$
-091
$$

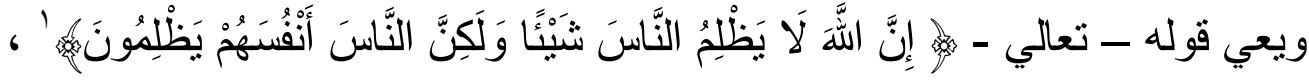
وأن الحياة الطيبة التي تعتبر مؤشرا للاستقرار الأسري لا مصدر لها إلا الإيمان بالله

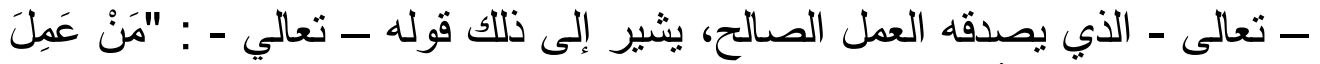

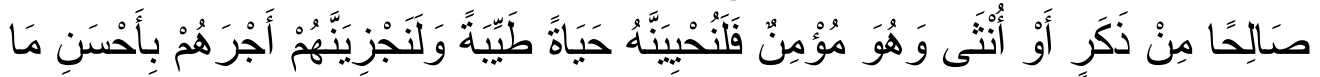

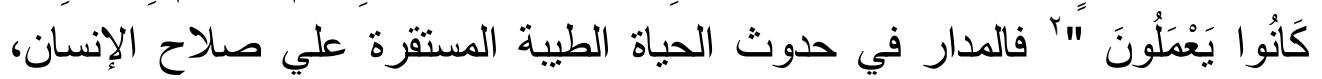
فالإيمان بالله - تعالى ـ و العمل بموجباته مجلبة للحياة الطيبة في النظام الأسري،

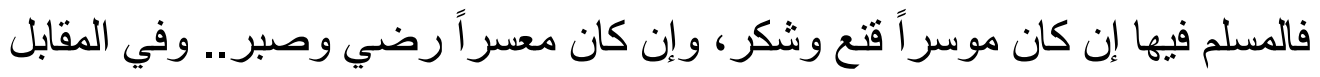

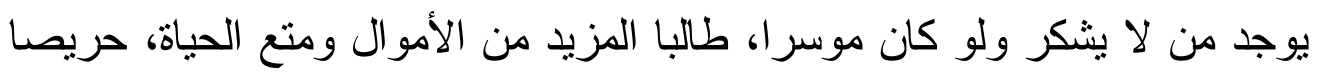

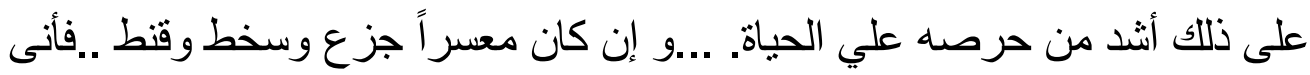
لمثل هذه الأسرة أن تتعم بالهدوء وتتمتع بالاستقرار؟؟ وواجب علب على الأسرة المسلمة

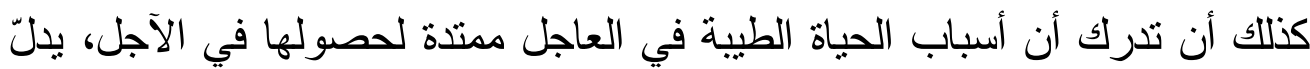

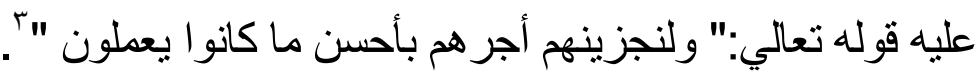

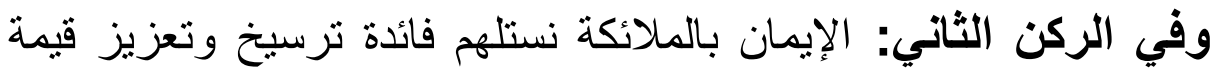

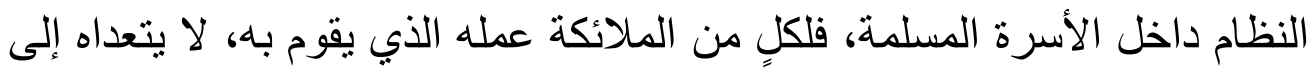

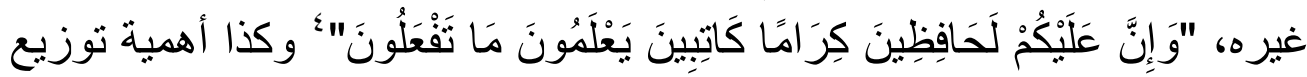
الأعمال، والقيام بالمهام خير قيام في ترتيب ونظام وإحكام، وتسخير كافة الإمكانت و الطاقات في سبيل إسعاد الأسرة.

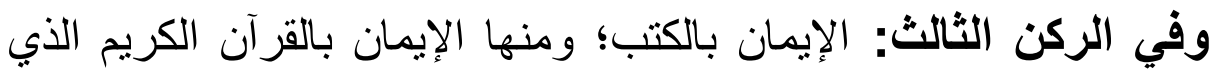
هو مصدر سعادة البشرية في عاجل أمرها وآجله، فالله الذي أنزله الإنهان بله أعلم بخلقه؛

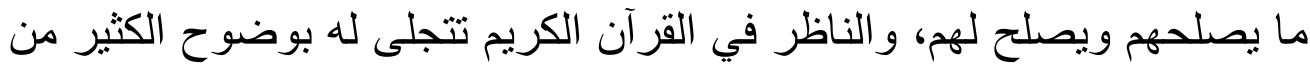

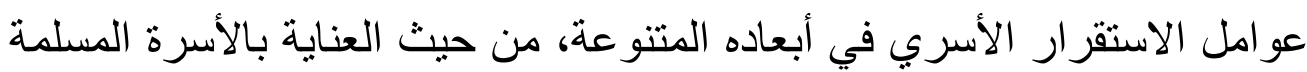

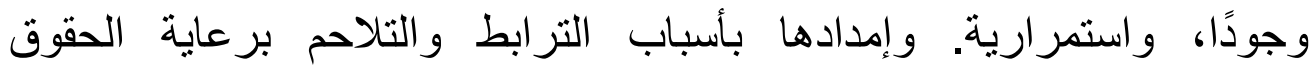

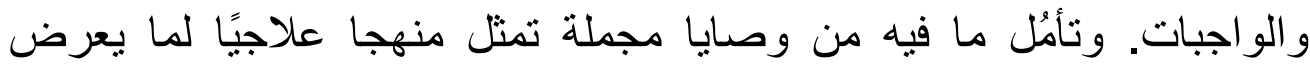

$$
\begin{aligned}
& 1 \\
& \text { r - النحل: } \\
& \text { r - النحل: }
\end{aligned}
$$

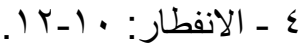


للأسرة من مشكلات و أزمات.

وفي الركن الرابع: الإيمان بالرسل، فبالاقتداء بهم أثز في تحقيق

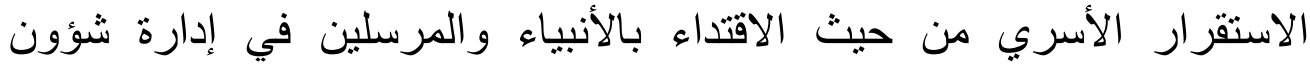

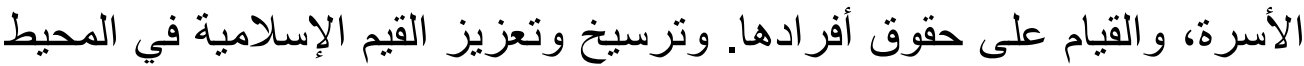

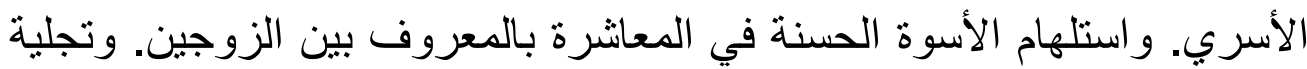

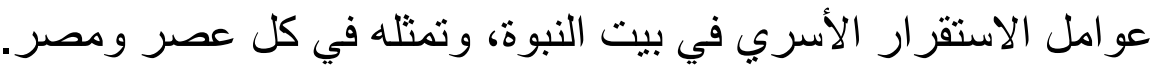
وفي الركن الخامس: الإيمان باليوم الآخر؛ فيمكن استلهام بعض التهن آثاره في الاستقرار الأسري من حيث كونه بربي في المسلم الإحساس بمسؤوليته عمن بن بالئن هم تحت و لايته، وكذا استشعار المسؤولية الفردية لدى كل فرد من أفر اد الأسرة. و انتهاج أسلوبي الثواب و العقاب في مجال التربية في المحيط الأسري. وفي الركن السادس: الإيمان بالقدر، وفائدة الإيمان به في تحقيق الاستقرار

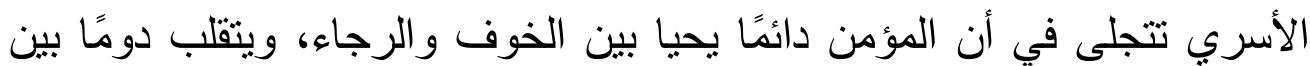
نعمتي الصبر والثكر في الثندة والرخاء. ويؤمن يقينًا بأن ما حدث دئ من مشكلات

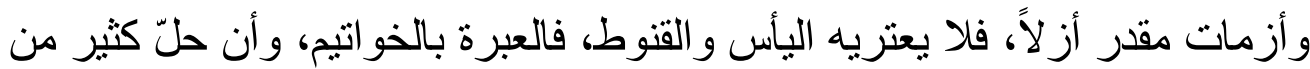

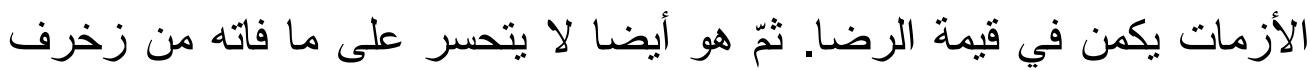

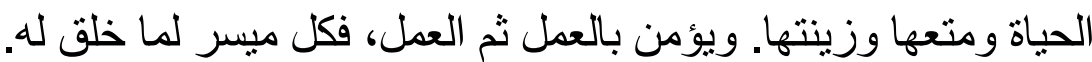
* وخلاصة ما سبق فإنّ أثر التدين الحقّ في الاستقرار الأسري

- إثناعة البركة في الفضاء الأسري، بطاعة الله - تعالى -، والقرب منه.

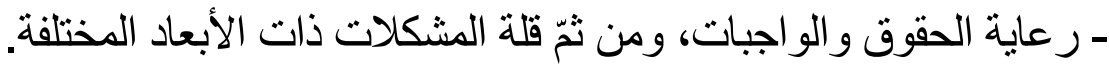
ـ الرضا بما قضى الله به وقدّر من مقومات الحياة المادية داخل بيت الزوبية. - تعزيز القيم الإيمانية لدى أفراد الأسرة، وأثره الإيجابي في الأي الاستقرار الأسري.

ـ التنشئة الصالحة للأبناء في جو مفعم بالتقى و الصلاح. * تحديات التدين الحقّ في المحيط الأسري: ـ الأمية الدينية، و الجهل بتعاليم الإسلام و أحكامه. ـ الاحتكام إلى معايير دنيوية خلال عملية اختيار شريك الحئه الحياة. 
- فقدان قيمة التو اصي بأداء الو اجبات الدينية.

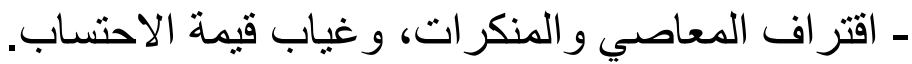
ـ الافتقار إلى القيم الإيمانية بين أفراد الأسرة.

\section{المطلب الثاني}

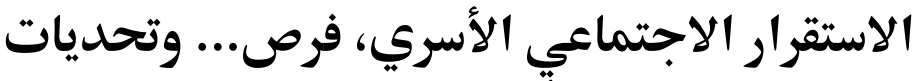

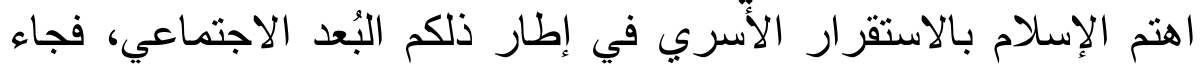
منبهًا على حُسن الاستفادة من الفرص الحقيقية من أجل ضبط الناحية الاجنية الاجتماعية

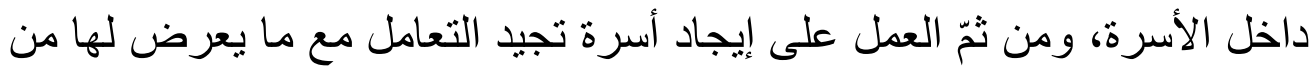

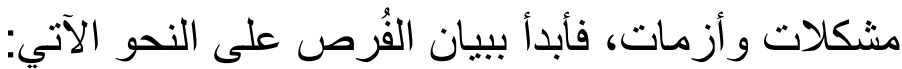
ا - توزيع الأدوار وتحديد المسؤوليات.

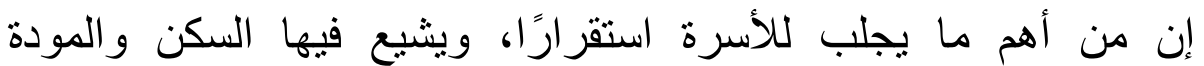
و الرحمة، وينأى بها عن كثثبر من الأزمات التي تعصف بكثثر من الأسر في ماني

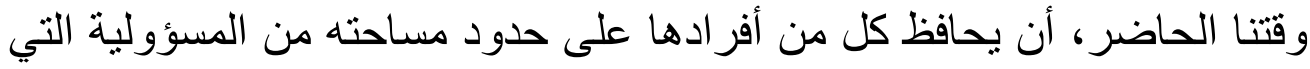
نيط بها، وحددها له الثرع، و التي جاءت وفق ما وهب الله لأصحابها من تكوين

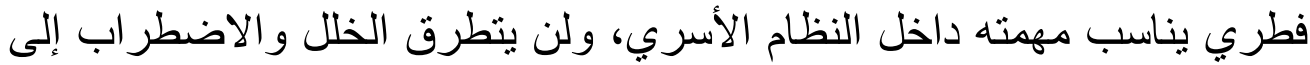

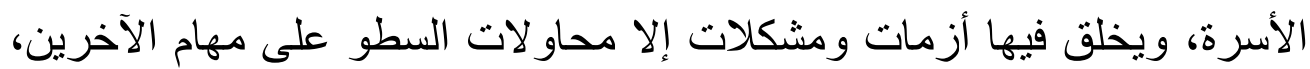

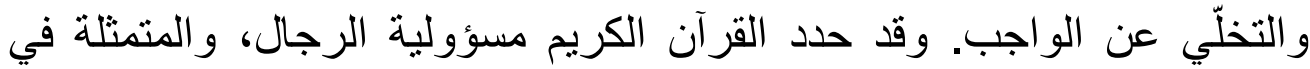

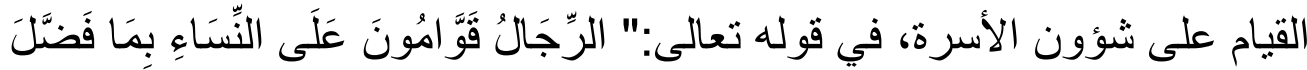

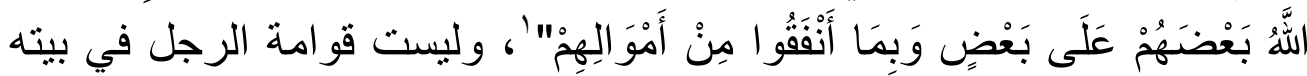
نوع تشريف، أو تسلط على المرأة، بل العكس هو الصحيح، فلم يفضل الرجل

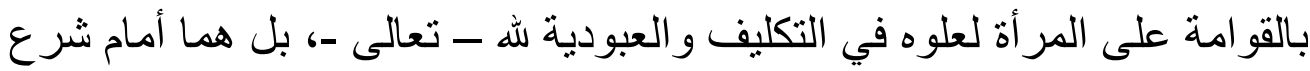

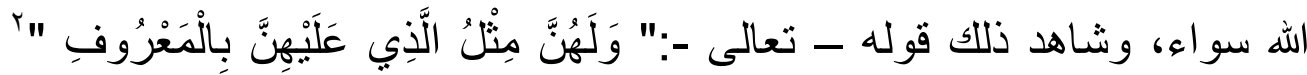
يقول ابن كثير:( أي ولهن على الرجال من الحق مثل ما للرجال عليهن فليؤدي 


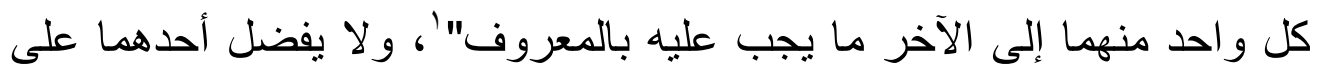

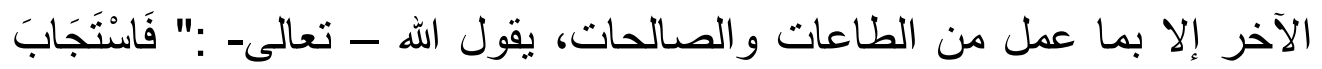

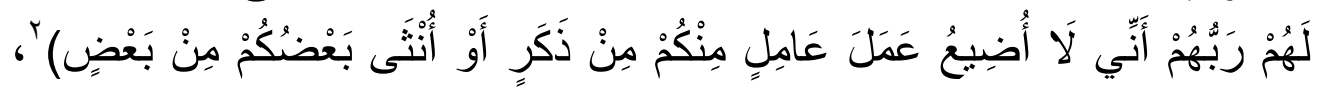

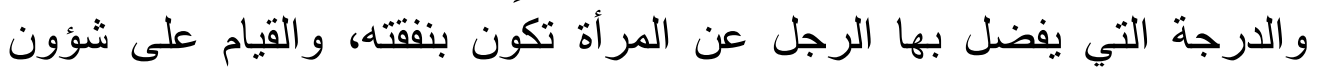

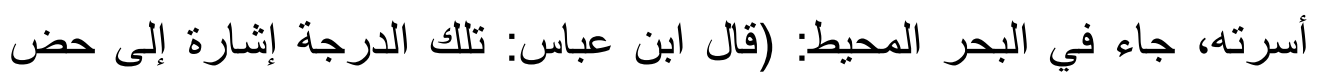

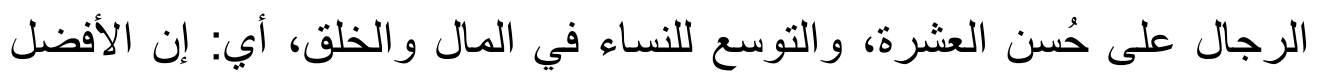

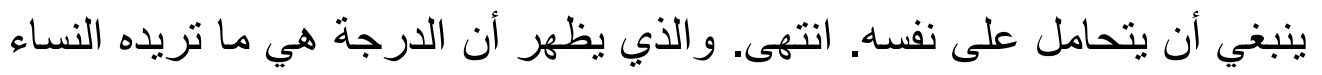

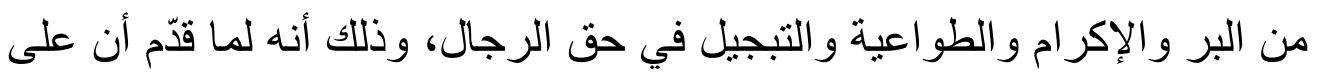

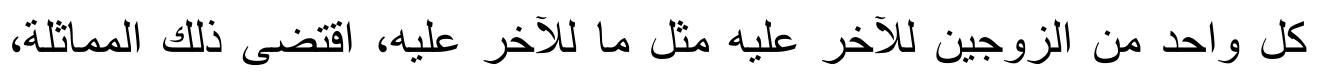

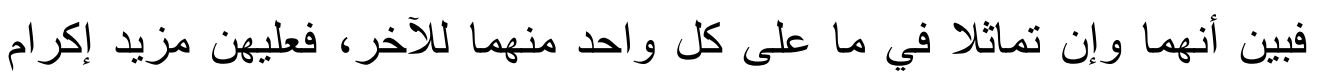

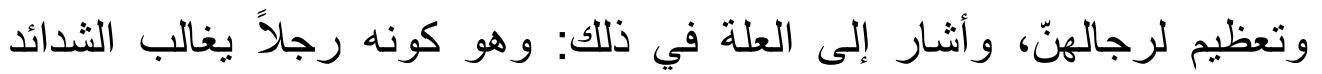

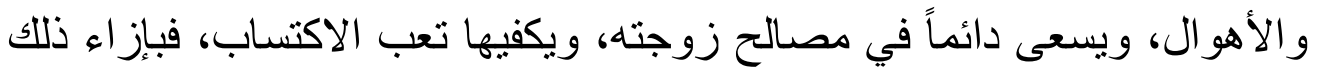

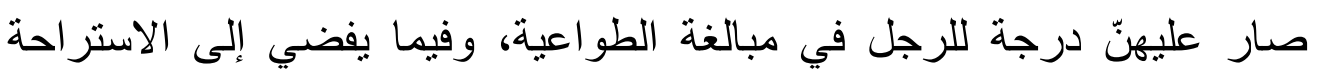
عندها)َ، وفي هذا الجو تسود السكينة ويحصل الاستقرار، ثمّ يأتي التوجيه

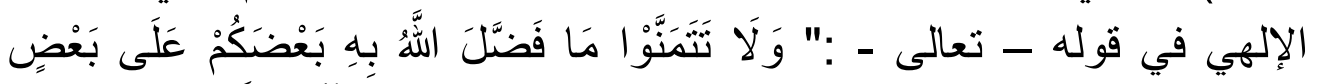

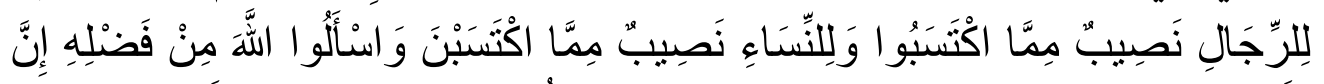

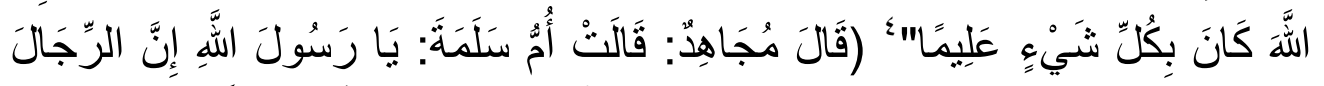

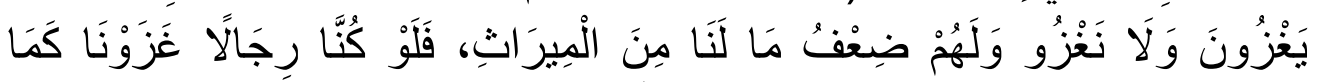

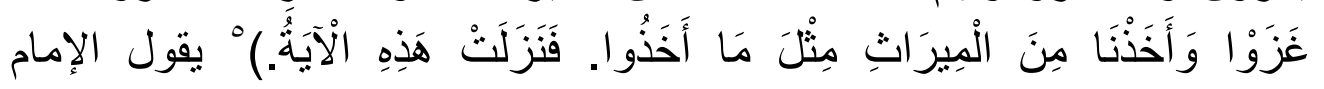

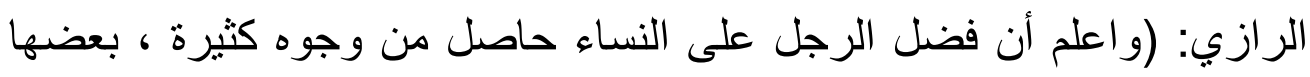

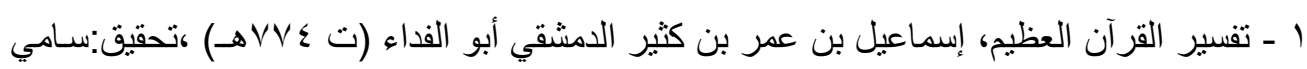

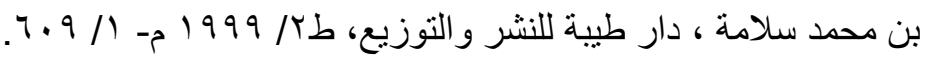

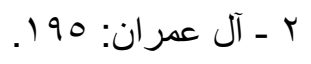

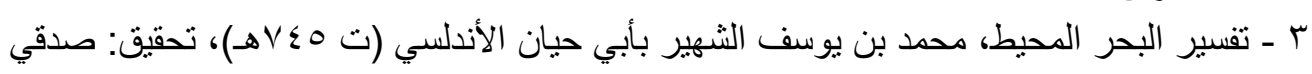

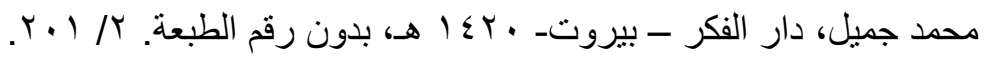

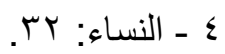

ه ـ معالم التنزيل في تفسير القرآن = تفسير البغوي، تحقيق: عبد الرزاق المهذي، دار إحياء التراث

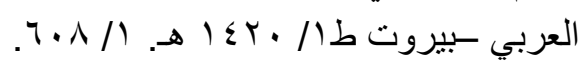


صفات حقيقية، وبعضها أحكام شرعية، أما الصفات الحقيقية فاعلم أن الفضائل

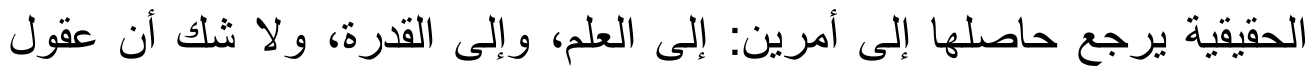

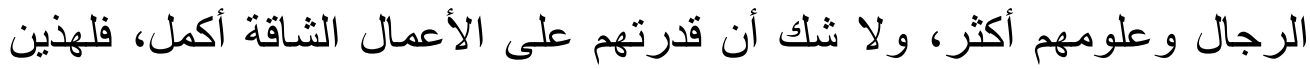

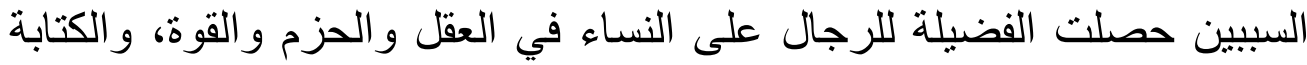

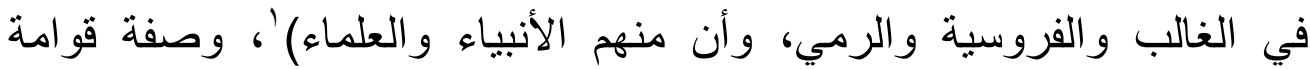
الأزواج علي أزواجهم تكون بالقيام على شؤونهن كقيام الولاة على الهى أمور

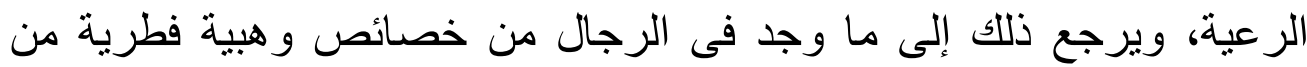
الاستعداد للقيام بهذه المهمة و الرسوخ فيها وليها، وما وجد فيهم من خصائص كسبية

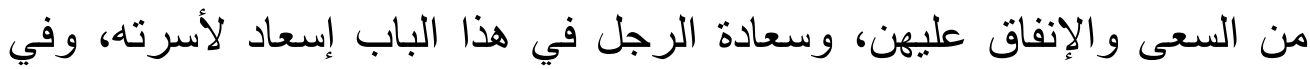

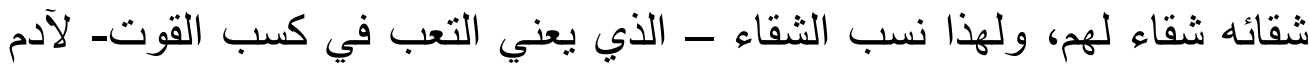

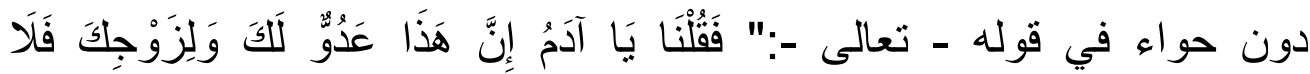

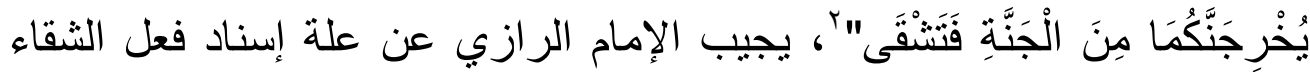
إلى آدم دون حواء مع اشتر اكهما في الفعل، فيقول: (الجواب من وجهين :

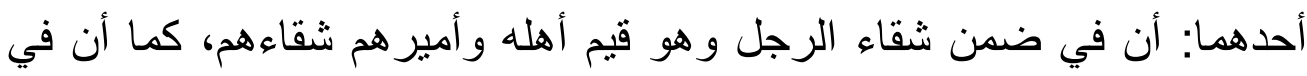

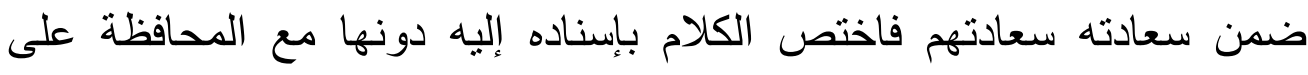

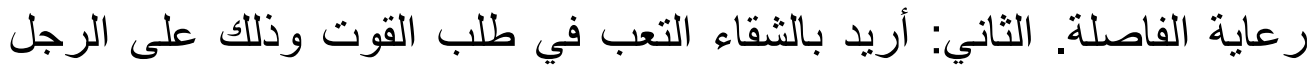

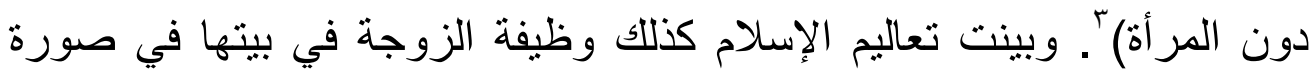

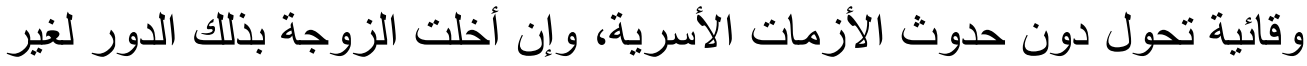

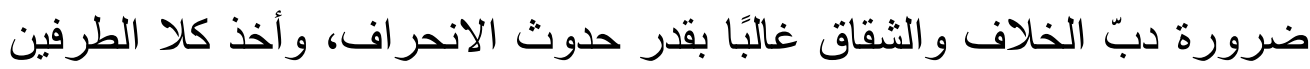
موقفاً يمثل تهديداً صريحاً لمؤسسة الزوجية، فالأصل أن تكون الزوجة في في بيتها،

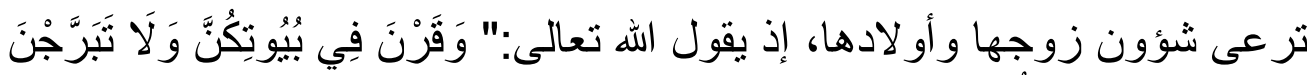

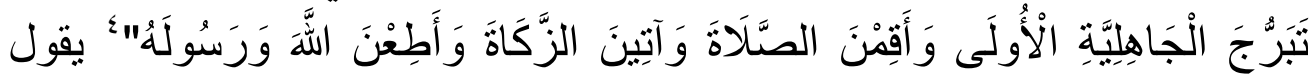

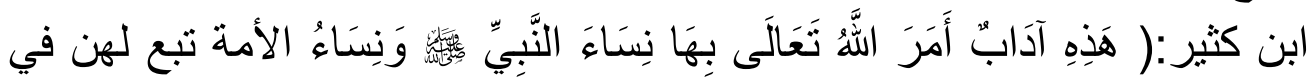

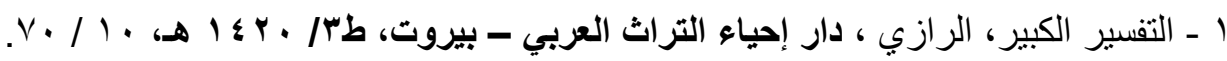
r - طه:

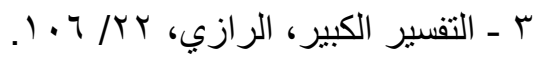
ـ ـ الأحزاب: سبر. 


$$
-7 \cdot r_{-}
$$

ذللك)'، وخير عمل المرأة ما كان في بيتها من صنعة تقوم عليها، أو مهارة

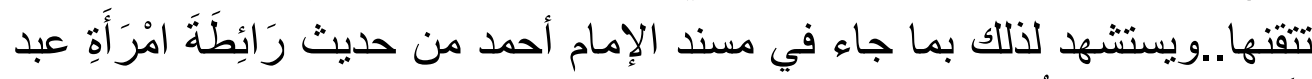

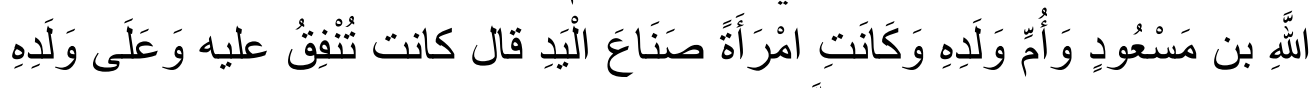

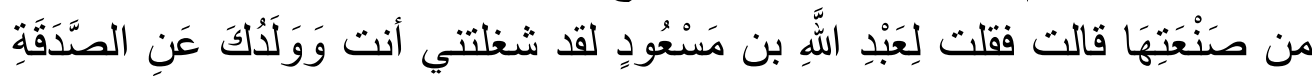

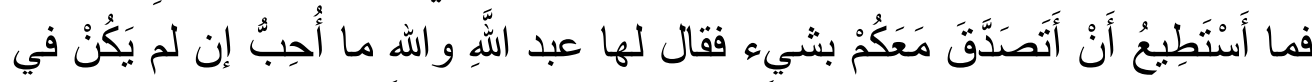

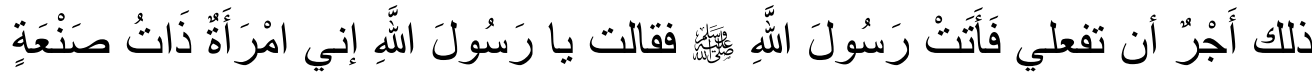

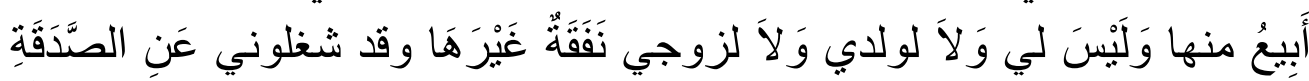

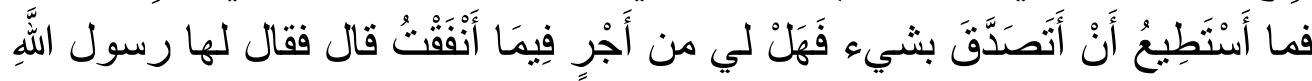

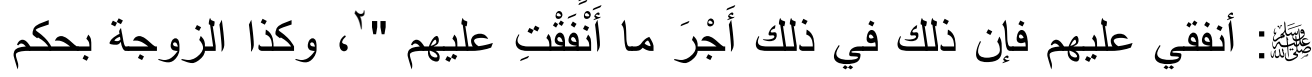

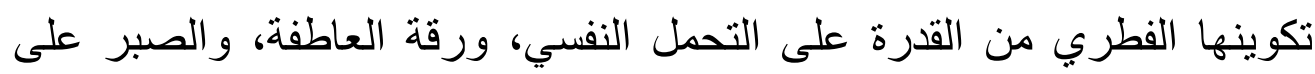

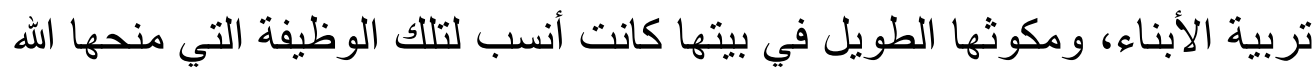

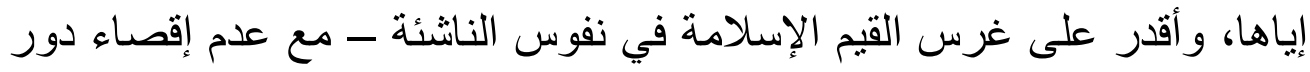

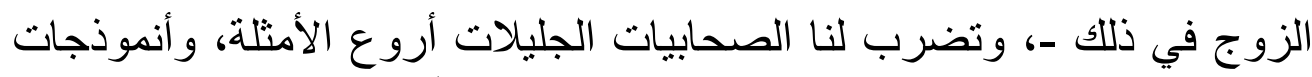
القدوة في ذلكم الميدان، ففي صحيح مسلم من حديث أَنَسُ فال: أتى عَلَّيَّ رسول

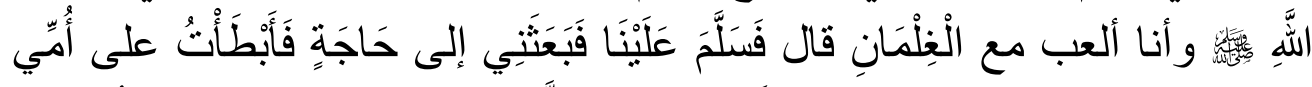

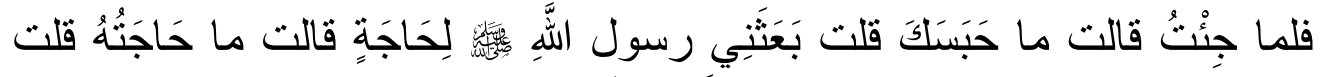

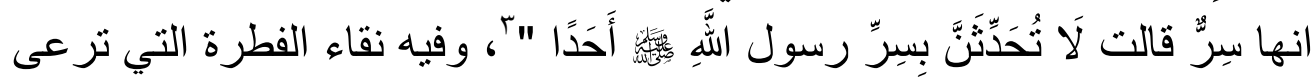

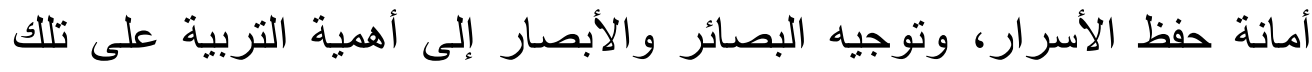

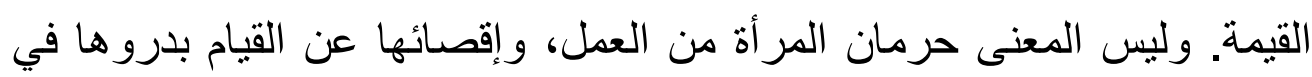
تنمية المجتمع ونفع الأمة، لكن ينبغي أن يكون في الأمر موازنة النة عادلة بين

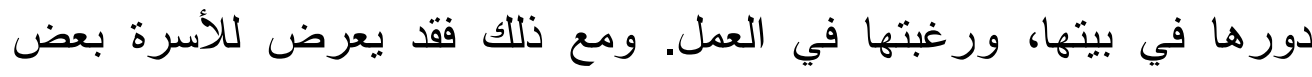

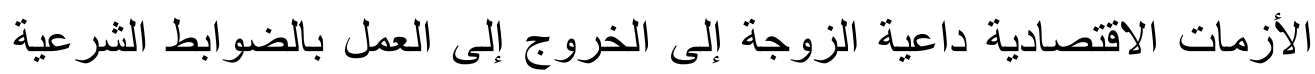
التي تحفظ إنسانيتها وكرامتها، فنشارك زوجها في عمل تنفق منه على أسرتها

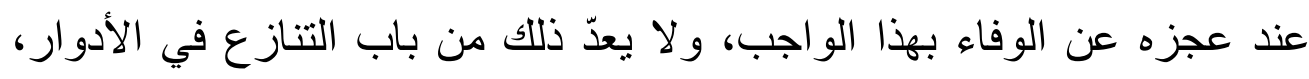

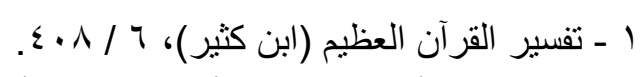

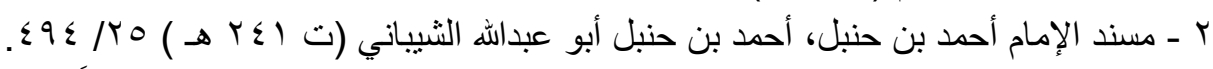

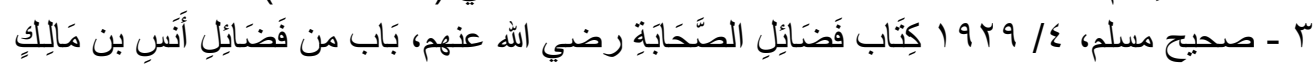


وتبدلها، وإنما ضرورة اقتضنها أزمة اقتصادية، فكان عملها بمثابة الدور

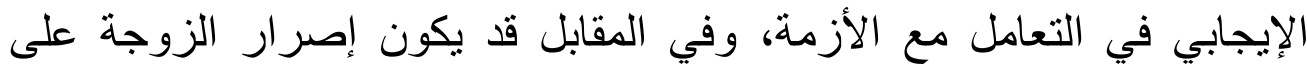

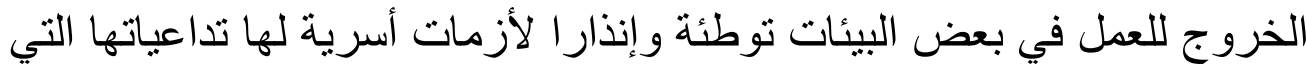
لا تخفى على العامة من إهمال لحقوق الزوج، وقصور في تربية الأبناء..

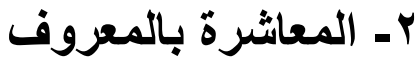

من الفرص التي ينبغي الاستفادة منها: حُسن المعاثرة بين الزوجين، وهو

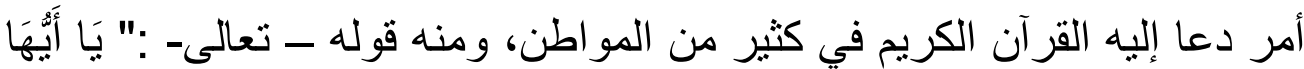

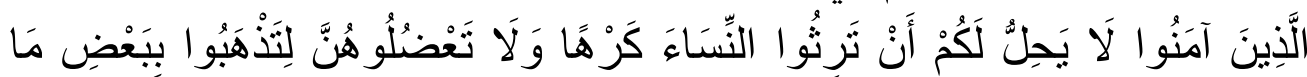

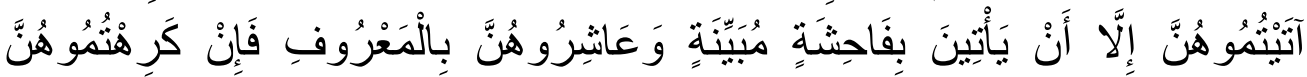

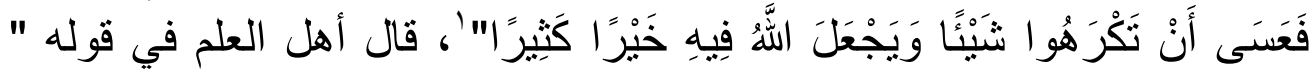

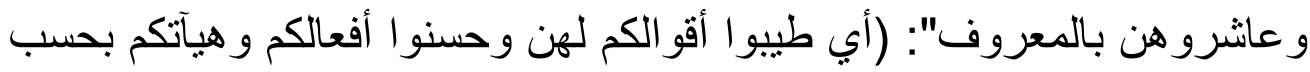

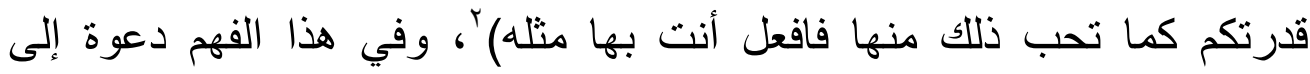

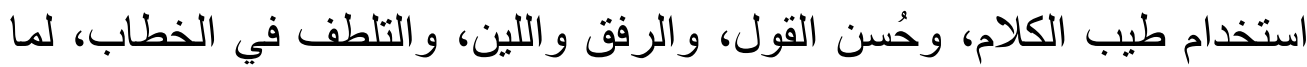

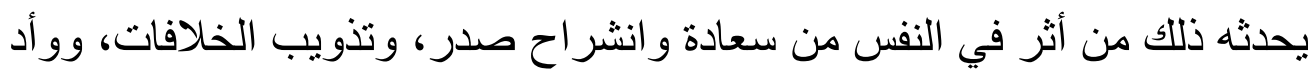
المشكلات.

\section{r- ترسيخ وتعزيز قيمة المشاورة}

وتهدف هذه الفرصة إلى إفساح المجال لإبداء الرأي بأريحية، وتجنب

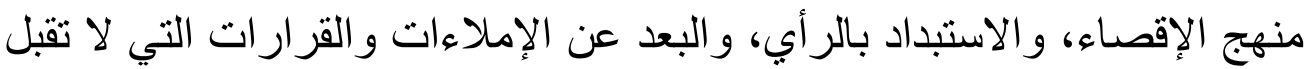
المناقتنة، ففي إفساح المجال للزوجة ـ مثنلا - لإبداء رأيها تقدير لذاتها، والأهاء وأنها

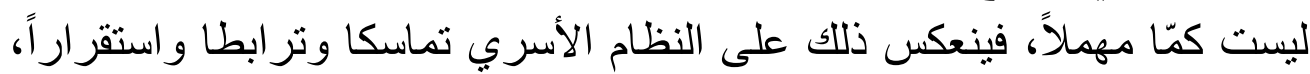

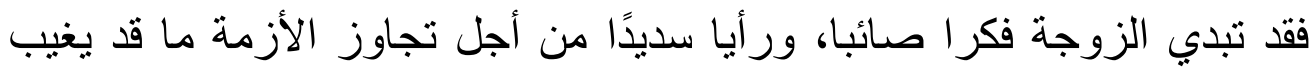

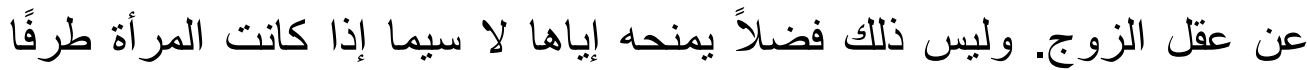
رئيسًا في الأزمة، فيطرح الزورج ولئ أمامها خيار اته التي يطمئن إليها، طالبًَا منها

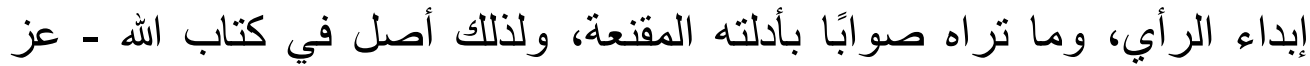
وجل - حيث التخيير فيما بتعلق بهن من أمور حياتية في نطاق الأسرة النبوية،

1 - سورة النساء، الآية :19.

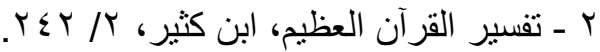




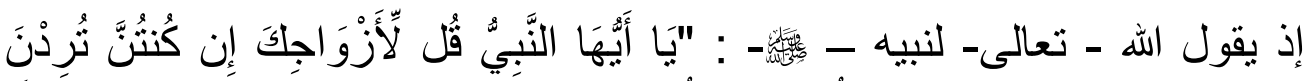

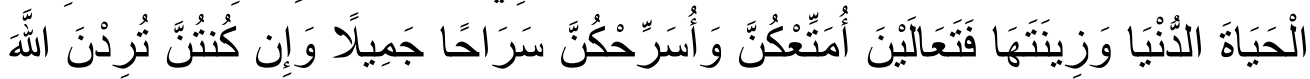

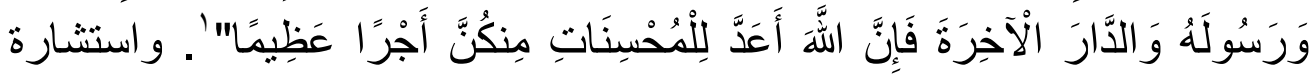

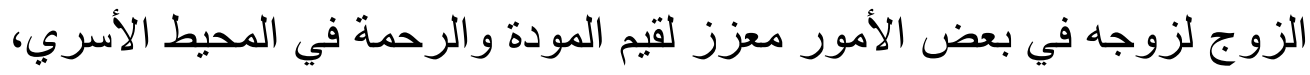
على أن هناللك بعض الأمور لا يجوز فيها الاستقلال والاستبداد بالر أي، كمسألة

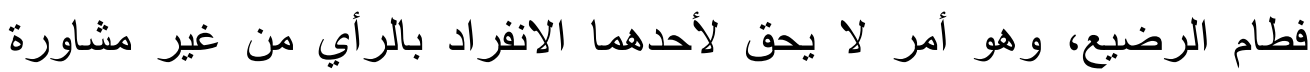

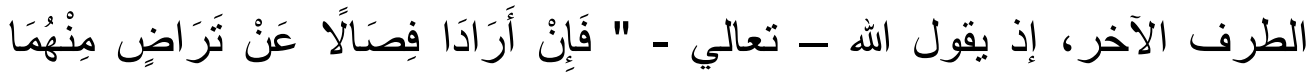

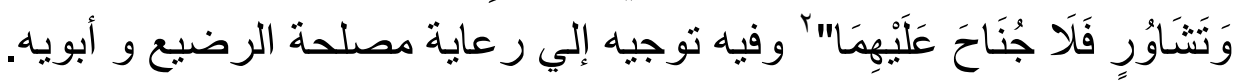

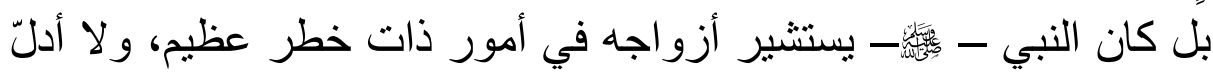

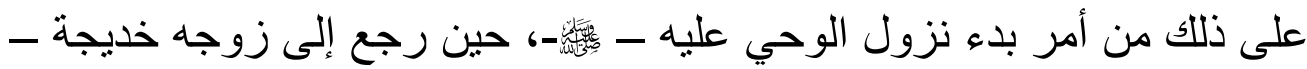

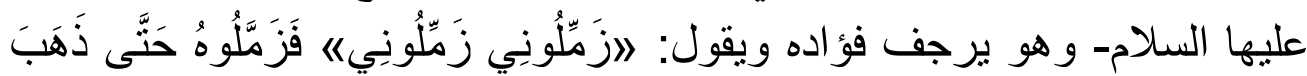

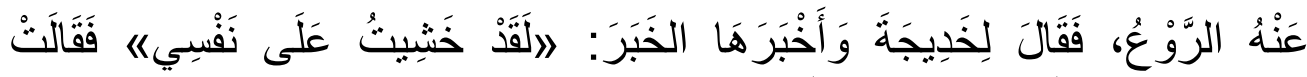

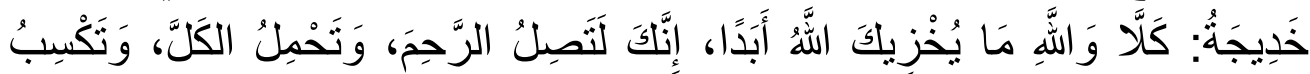

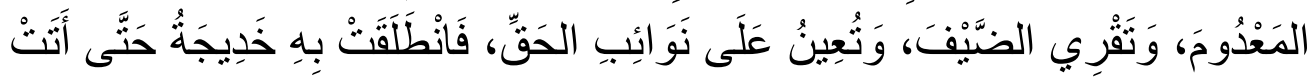

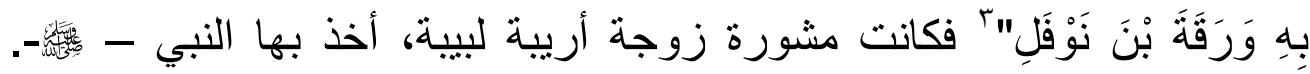

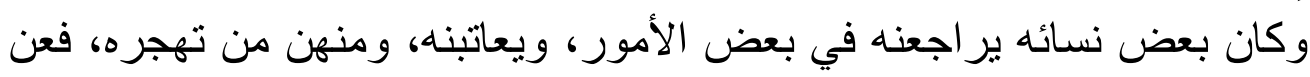

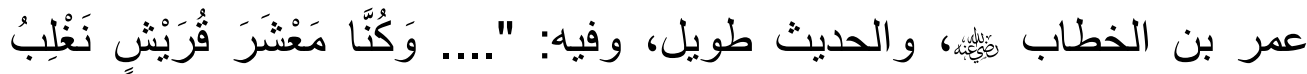

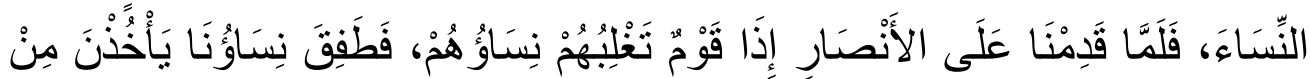

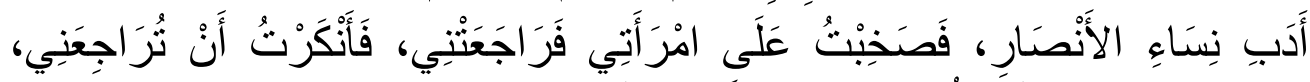

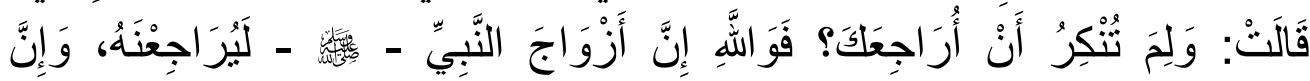

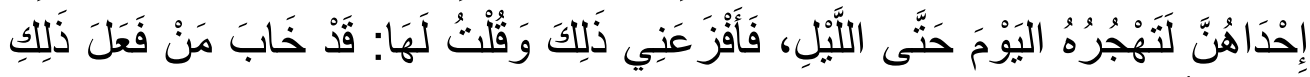

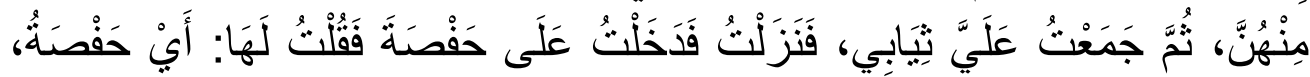

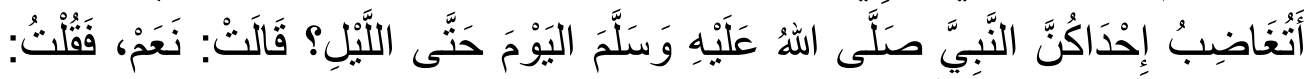

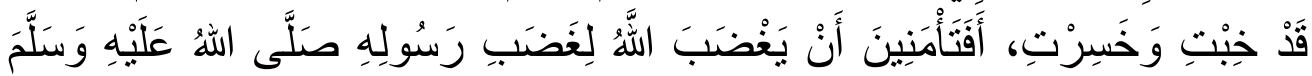

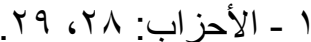

$$
\begin{aligned}
& \text { r - البقرة: سبr الاحز الب }
\end{aligned}
$$

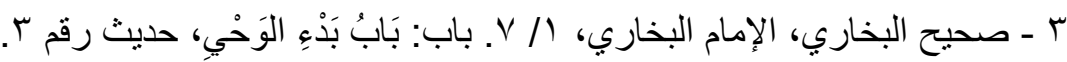




\section{$-7 \cdot 7$.}

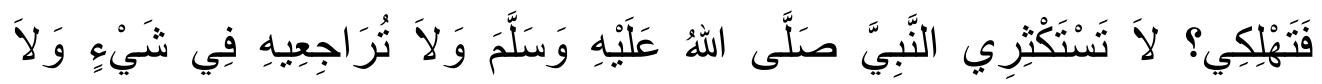

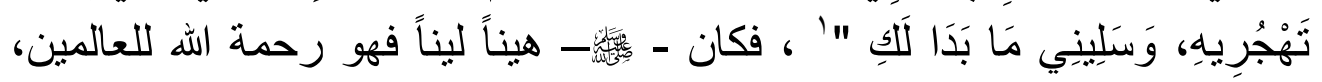

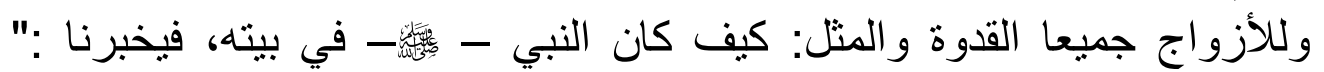

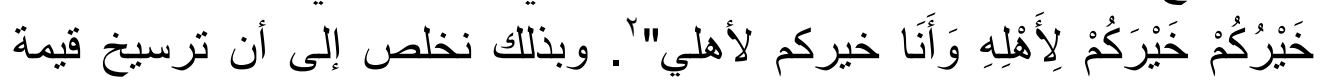

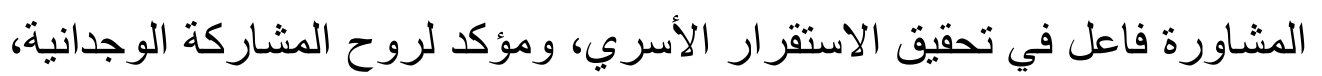

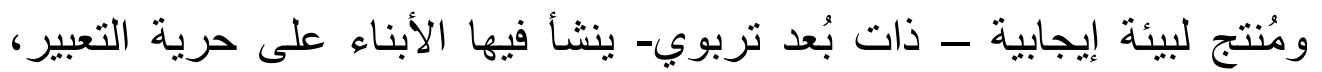

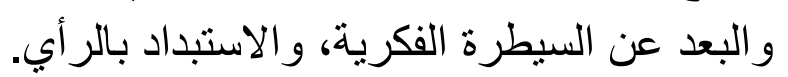

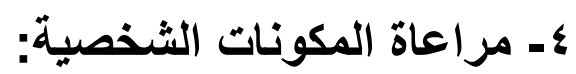

مما يعزز الاستقرار الأسري مراعاة المكونات الشخصية لاهى أفراد

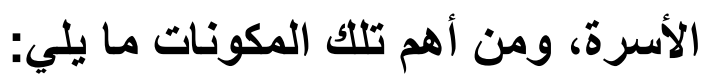
أـ المكوّن العقليّ، حيث إن الناس يختلفون ويتفاوتون في قدر اتهم العقلية، فمنهم الفذ، والذكي، وضعيف العقل، وعديمه، دلّ على ذلك التفاوت كثثر من

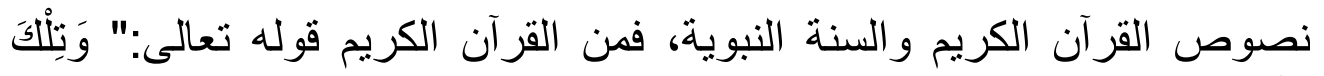

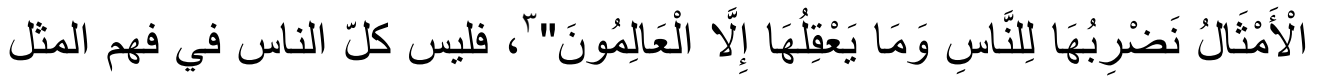

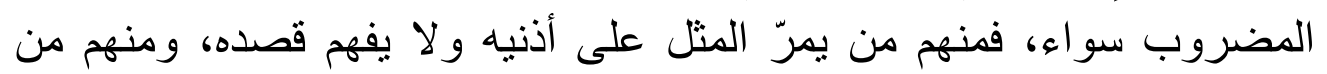

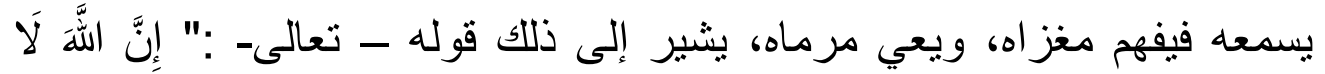

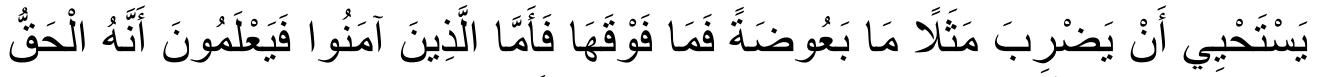

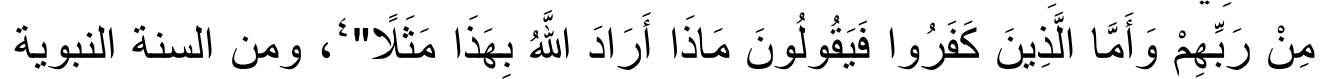

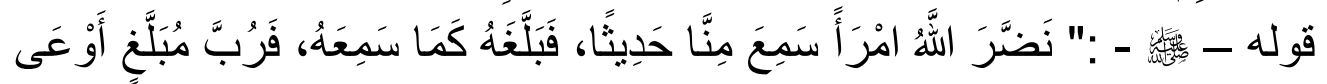

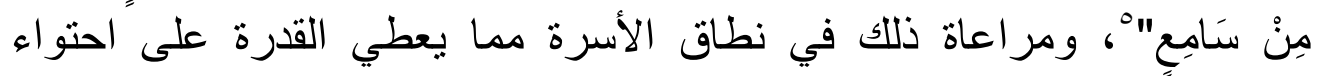

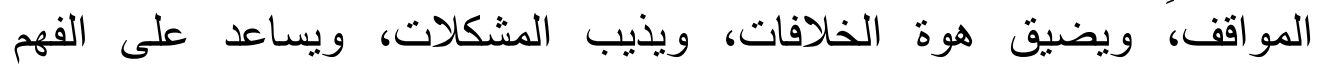

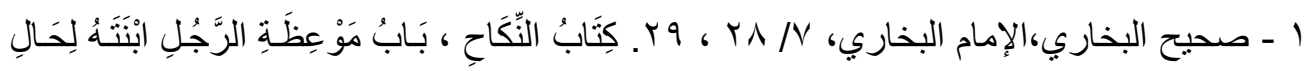

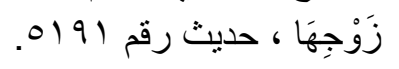

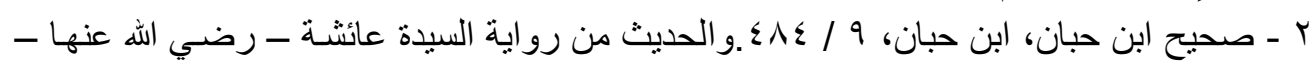

$$
\text { ז ـ ـ العنكبوت: حسيث صحيح. }
$$

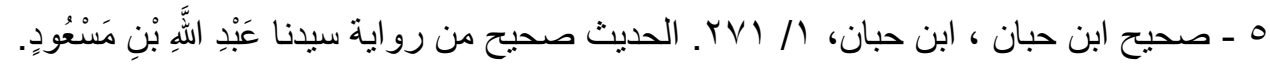




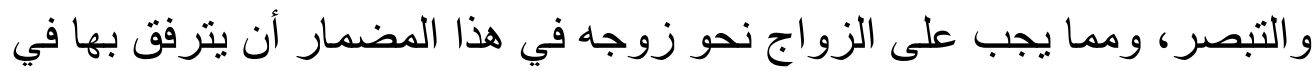

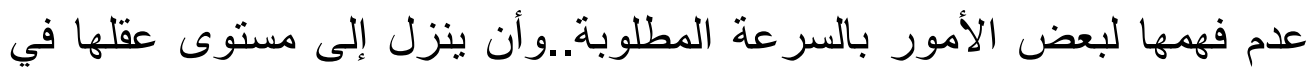

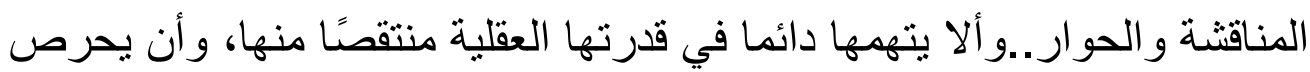
على تعزيز تقتها بنفسها، فذلك أدعى للبذل والعطاء في المحيط الأسري...وقد

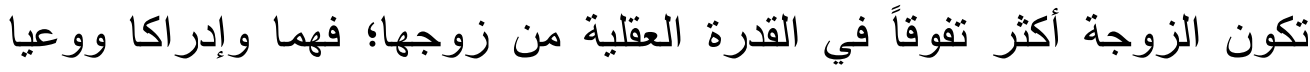
وثقافة...، فيُطلب منها ما سبق بيانه، حتى تستقيم الأمور، وتصفو لهور لهما الحياة.

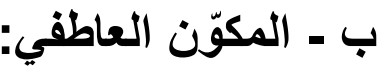

يحتاج المكون العاطفي في الزوجين إلى إثباع يتجاوزان بـه مصاعب

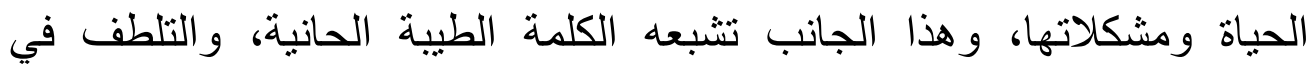

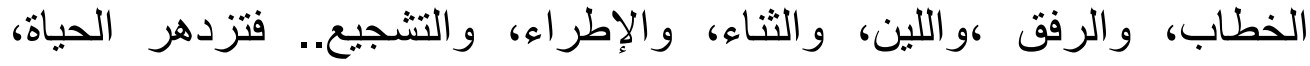

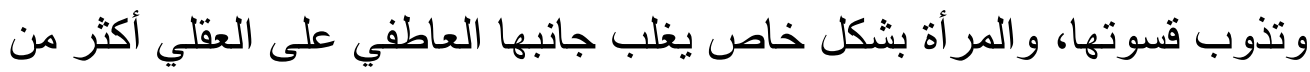

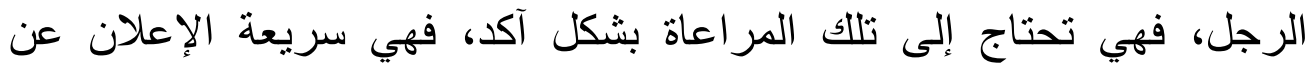

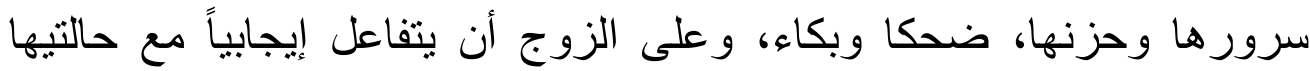

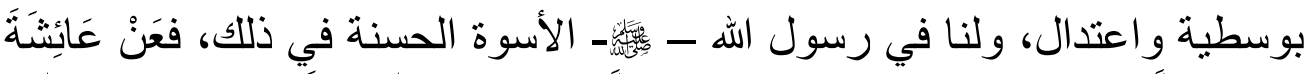

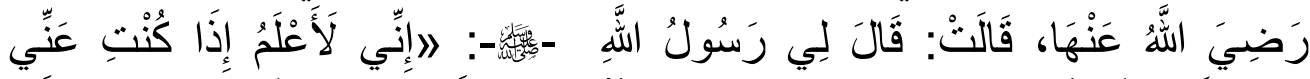

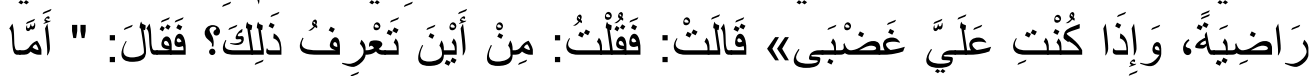

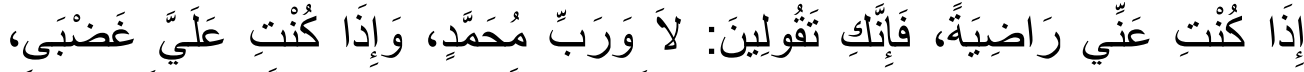

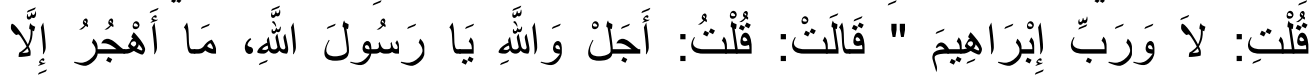

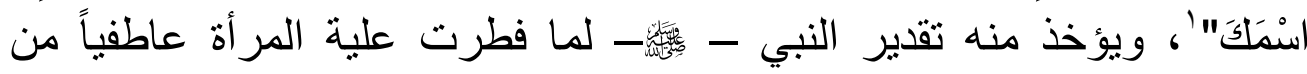
الغيرة المحمودة على زوجها، وملاحظة أثر ذلك في أحو الها وتصرفاتهاتها، وفيه فئه

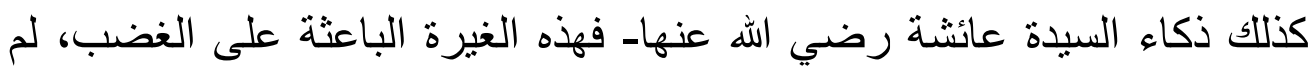

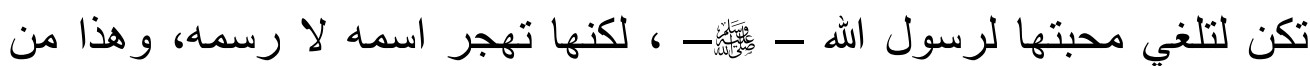

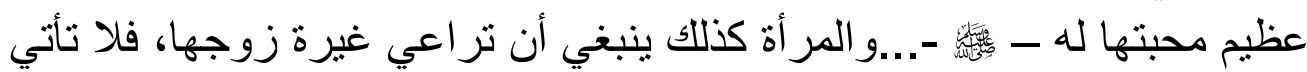
بكل ما يثير فيه ذلك الجانب طلبا لمصلحة مزعومة، والو اقع أن فيه شر كبير يكدر الحياة الأسرية، فالعاقلة هي التي تتحفظ أن تثير ذلك في زوجها أبها احتر امًا

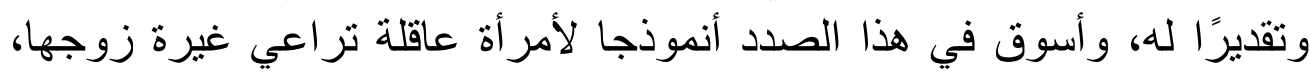

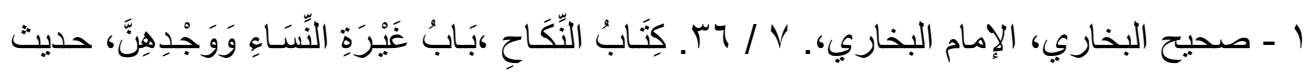
رقم 
$-7 \cdot \Lambda_{-}$

في ظرف اقتصادي ليس بالهين، تللك هي السيدة أَسْدَاءَ بِنْتِ أبي بَكْرِ رضي الله

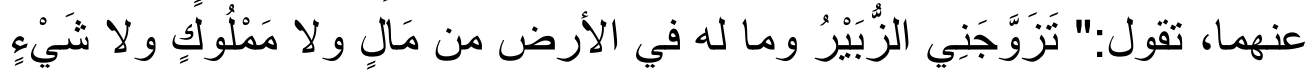

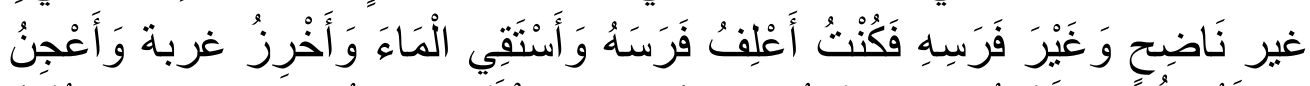

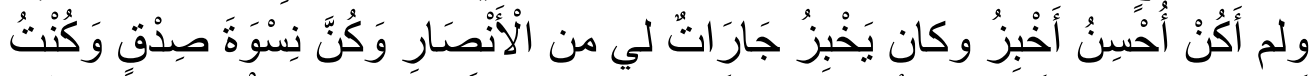

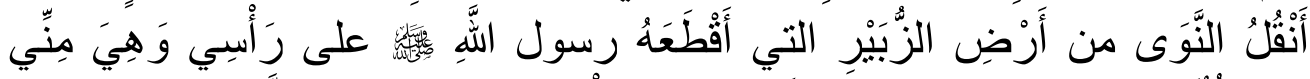

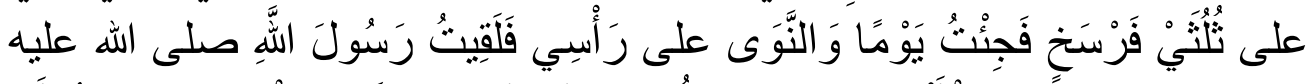

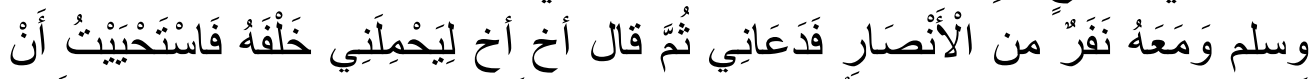

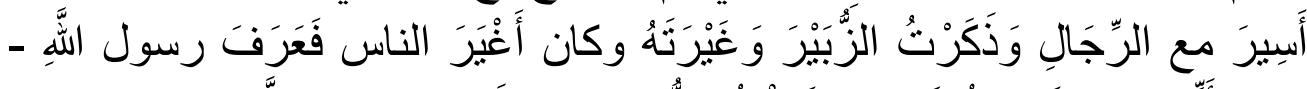

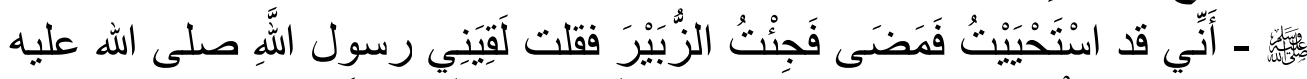

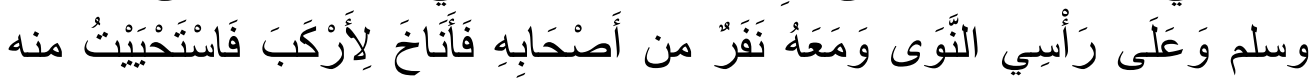

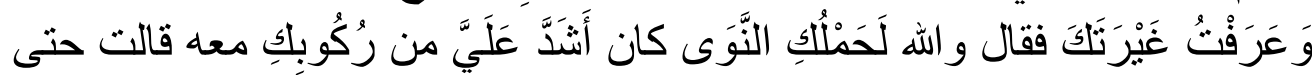

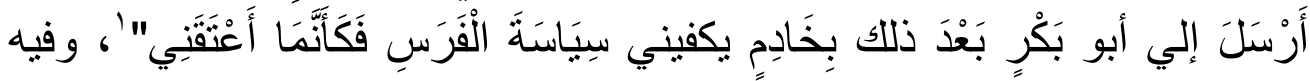
حياء السيدة أسماء - رضِي الله عنها- ومعرفتها بغيرة زوجها..و علو همتها في خدمة بيتها، وصبر ها على ذلك.

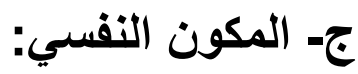

من الفُرص التي ينبغي الاستفادة منها في النظام الأسري، مر اعاة المكون النفسي لدى أفراد الأسرة، وإلا فإن المصادمة، و إساءة التعامل قد تجلب أزمات أسرية تستنفد جهد أطر افها، في ظل ما تعانبه كثير من الأسر المعاصرة من

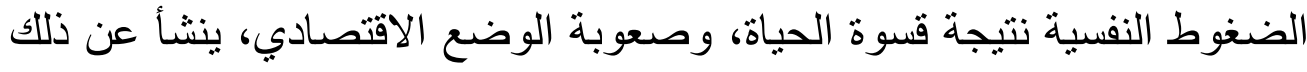
قلق وتوتر إزاء الرغبة في تعديل أوضاع الأسرة الاجتماعية أو الاقتصادية...،

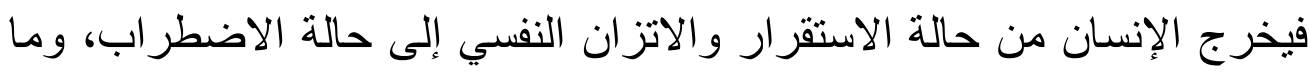

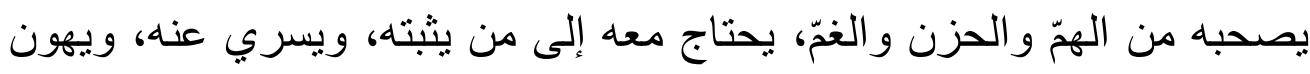
عليه صعاب الأمور، ومراعاة هذا الجانب في الإنسان أمر دعا إلبه القرآن

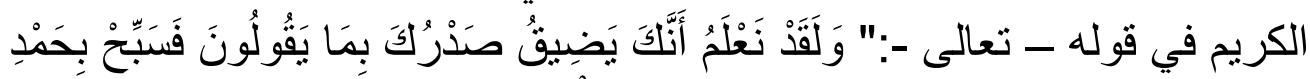

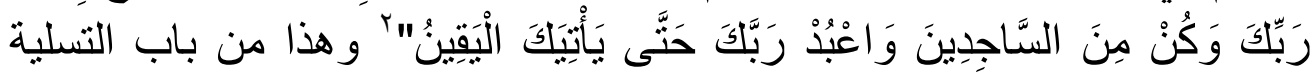

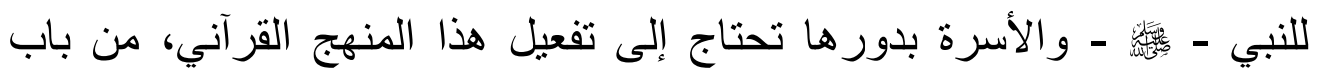

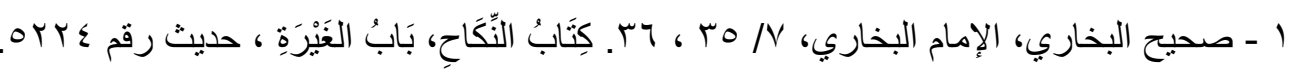


$-7 \cdot 9$

التثبيت و الدعم النفسي لأفر ادها.

*تحديات الاستقرار الاجتماعي الأسري:

- سو ء الاختيار، و غياب التكافؤ بين الزوجين.

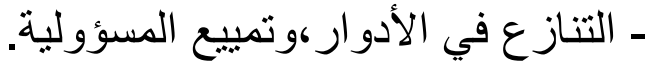

ـ الندية في المعاملة بين الزوجين.

ـ الغيرة المذمومة.

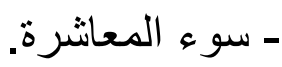

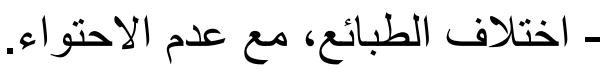

ـ التنكر للمكونات العقلية و العاطفية و النفسية.

$\star * * * * * * * * * * * * * * * * *$

\section{المطلب الثالث}

\section{الاستقرار الاقتصادي الأسري، فرص...وتحديات}

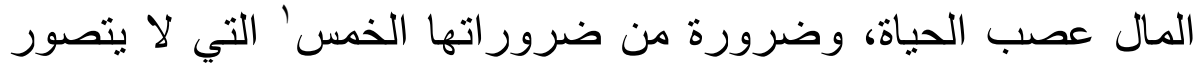

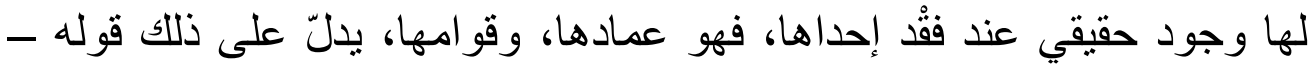

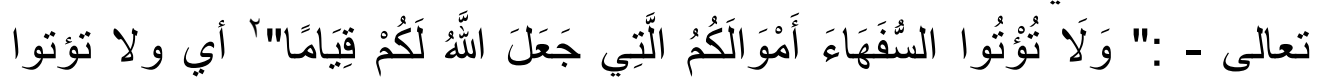
السفهاء أموالكم التي هي في الأصل أموالهم، حيث لا يحسنون التصرف فئ فيها

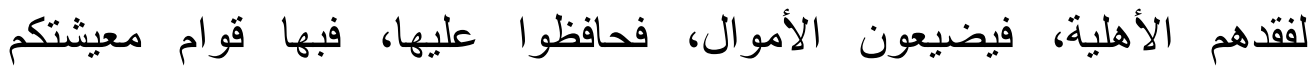

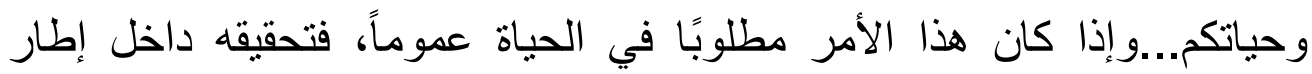

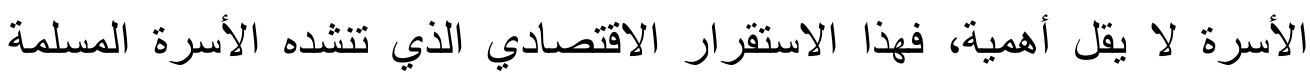

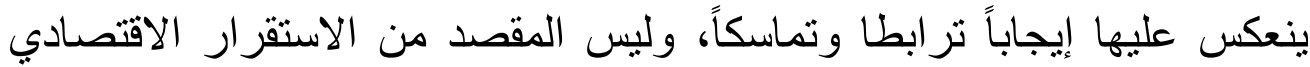

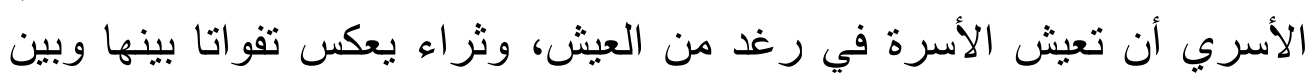

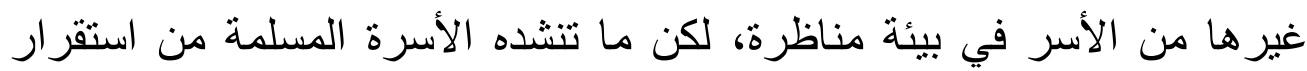

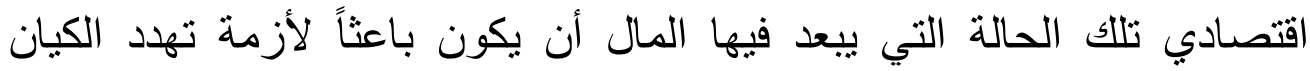
الأسري، فكثير" من الأزمات الأسرية يظهر المال فيها كسبب رئيس، ناتج أحيانًا

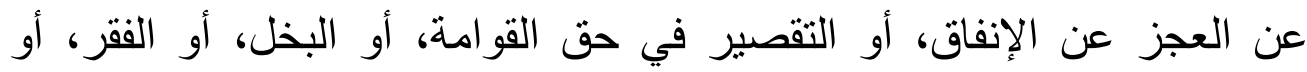

1 ـ ـ الضرور ات الخمس: الدين و النفس و العقل و النسل و المال.

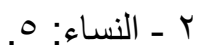




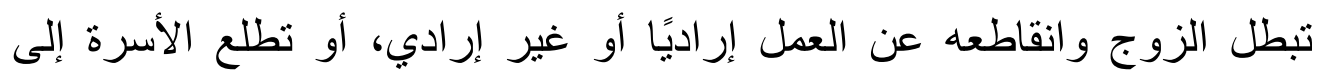

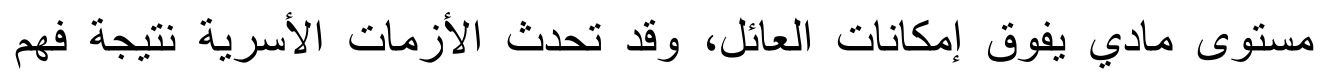

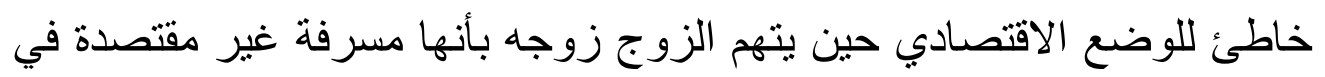

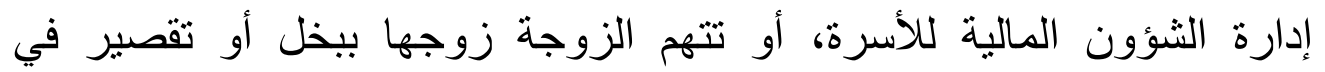

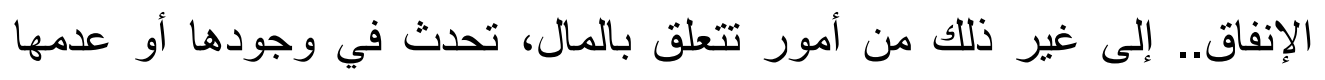

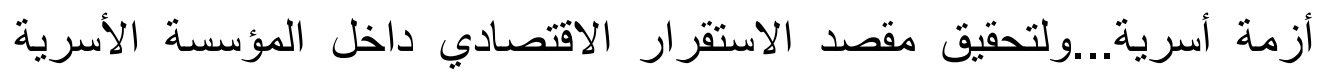

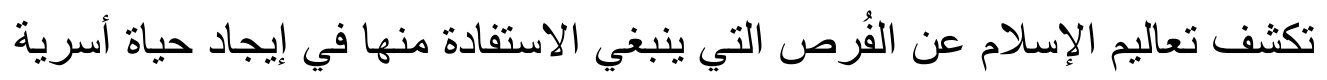

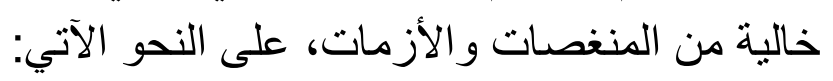
1- إنيسير المهور:

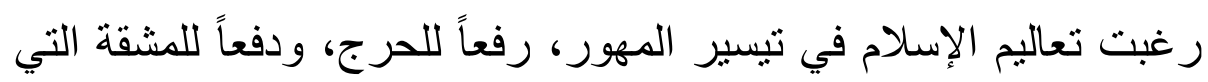

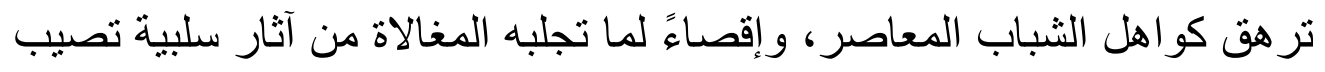

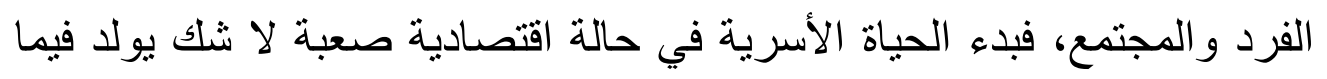

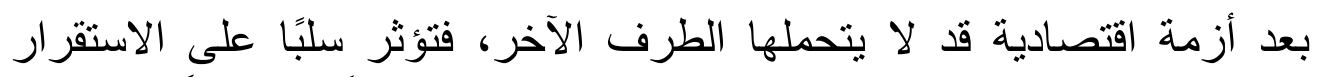

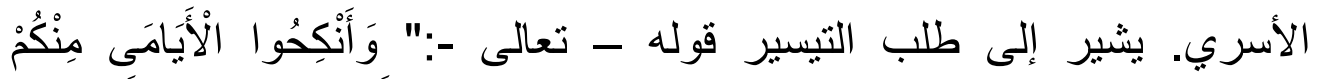

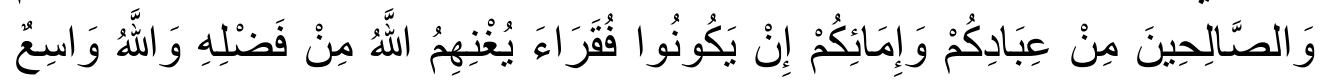

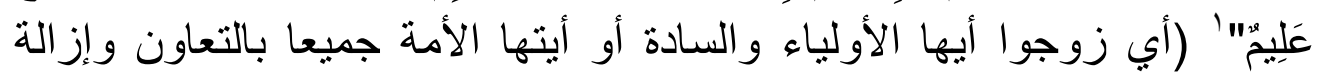

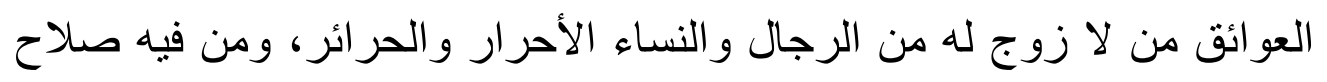

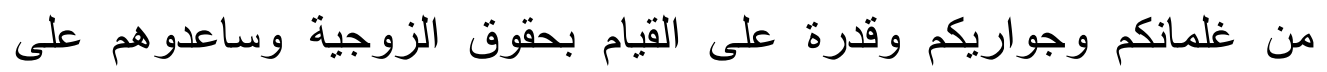

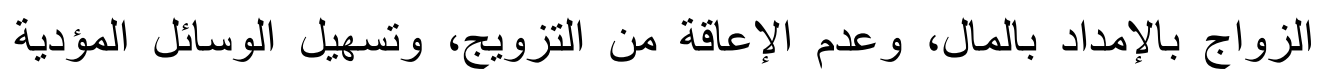

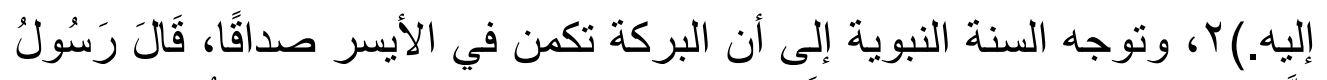

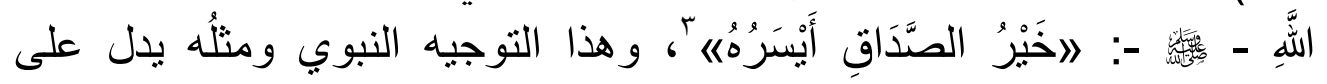

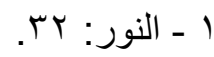
r - التفسير المنير في العقيدة و الثريعة والمنهج، د و هبة بن مصطفى الزحيلي، دار الفكر المعاصر

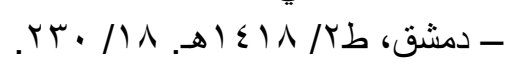

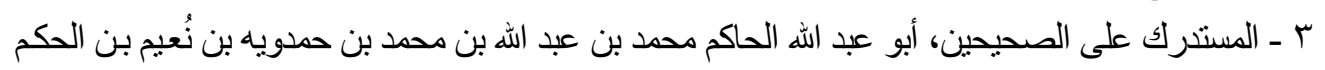

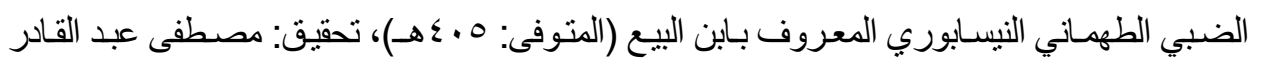

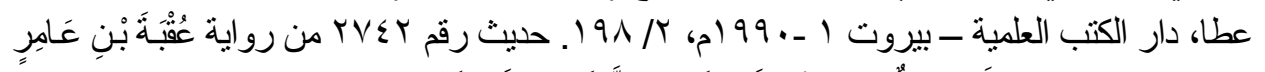

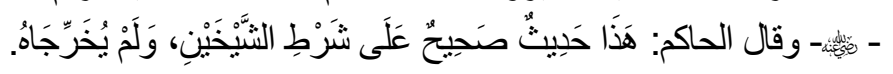




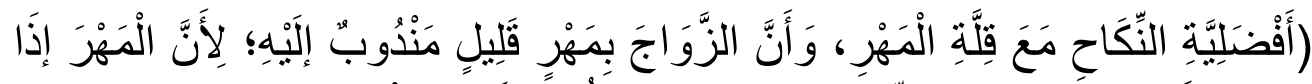

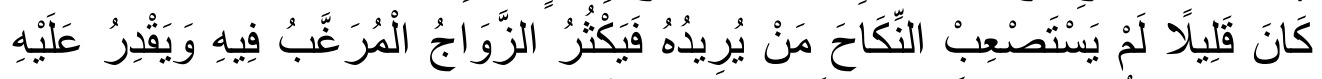

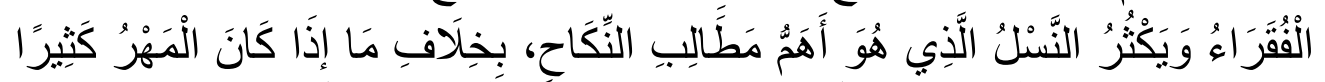

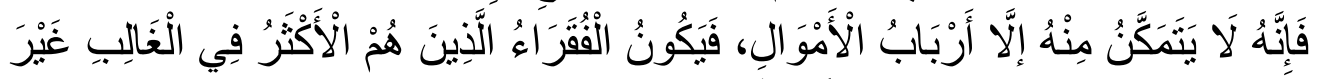

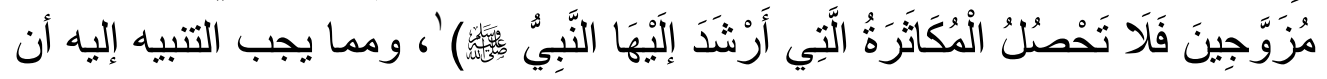

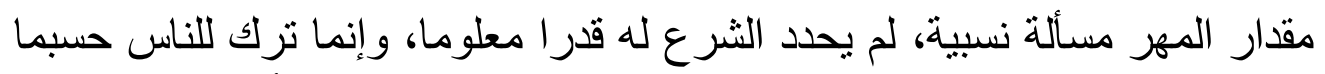
يتفقون عليه قلّ أو كثر، لكنه في التوجيه النبوي السابق (دَلَالَّة عَلَى اسْتِحْبَابِ

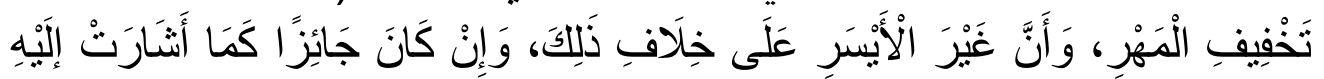

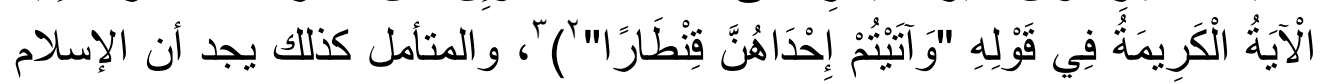
يجعل من الترغيب في تيسير المهور خطوة استباقية للقضاء على كثير من ون التهن

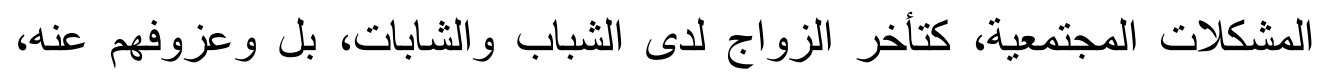

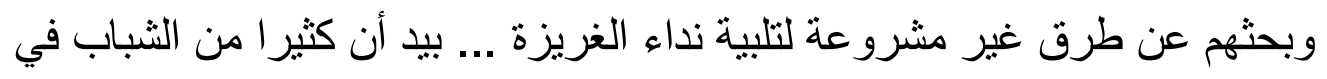

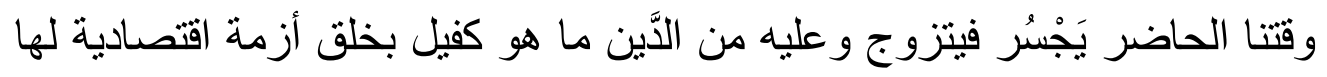

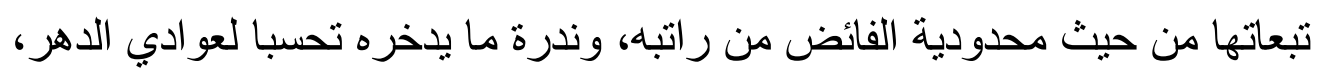
وقد لا تصبر الزوجة معه على شظف العيش، فنتند الأزمة الاقتصادية في المحيط الأسري، ينتج عنها الخلاف، و الثقاق، وربما الفراق.

\section{r - القدرة على النقة عنة}

المقصود بها أن تتوافر لاى الرجل القدرة المالية على مهر الزوجة

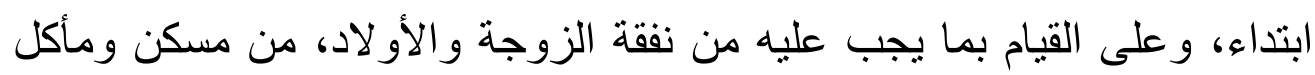

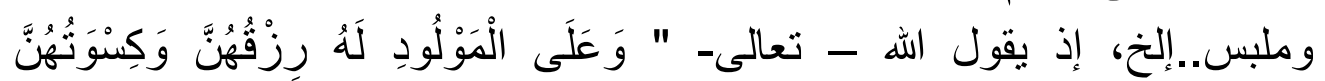

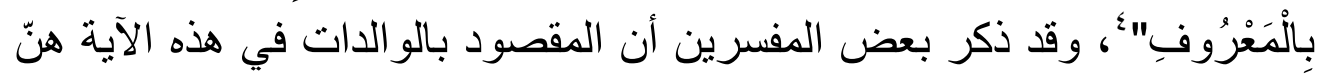

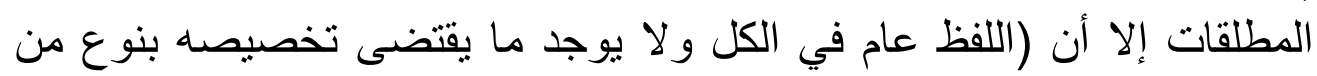

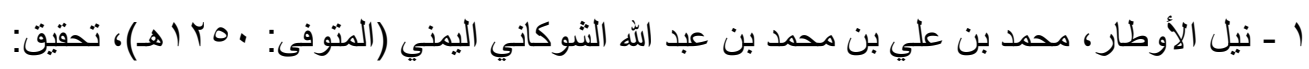

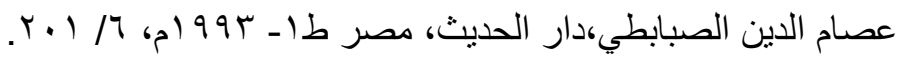

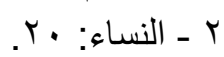

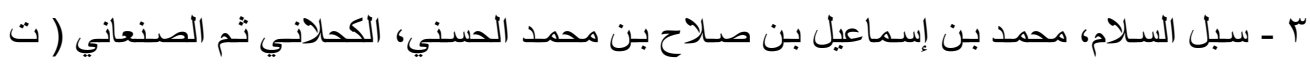

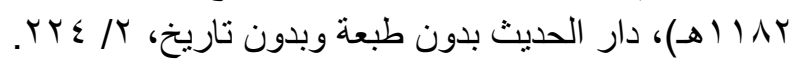


الأمهات)' . ومر اد الآية الكريمة تحديد النفقة الو اجبة على الزَوج (أَيْ وَعَلَى وَالِِ

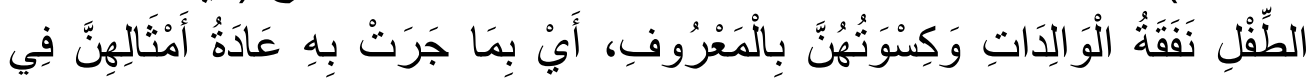

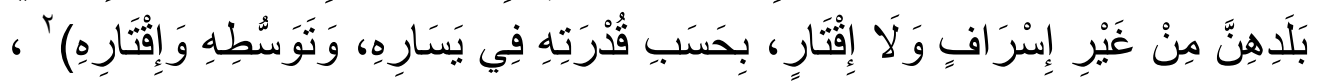

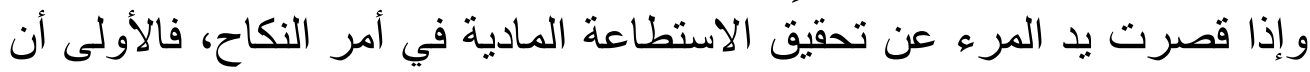

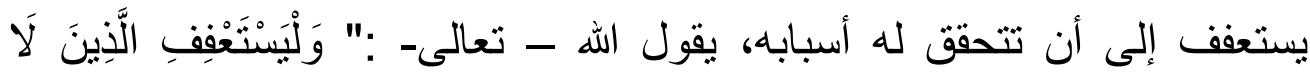

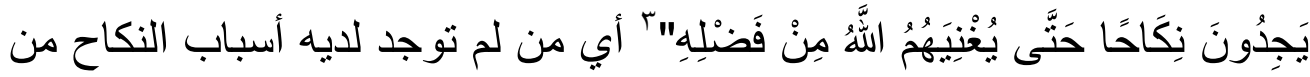

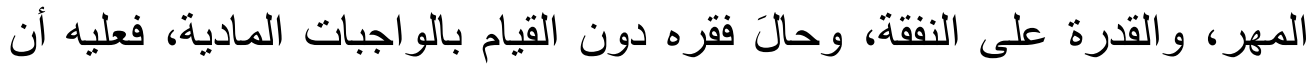

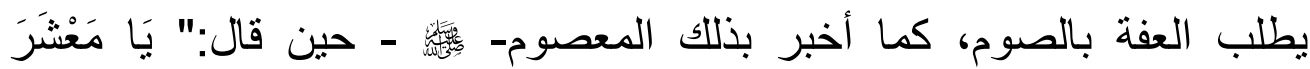

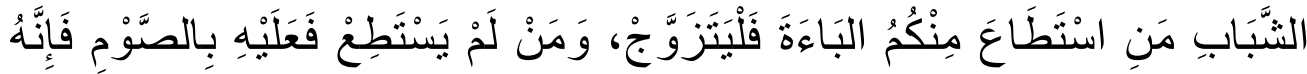

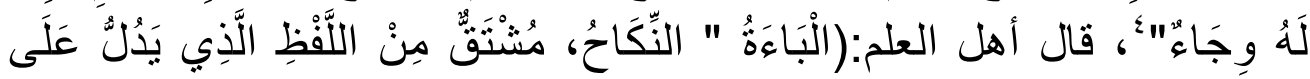

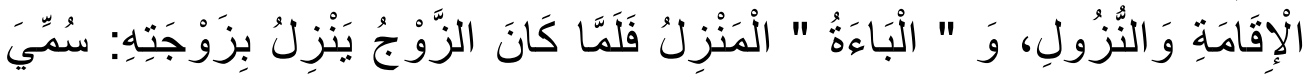

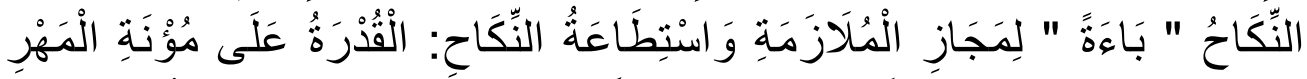

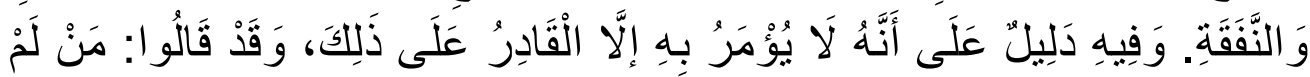

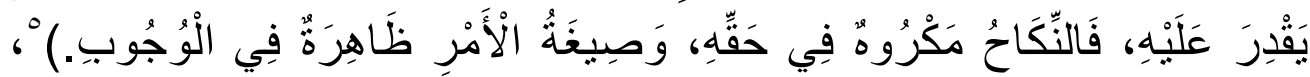

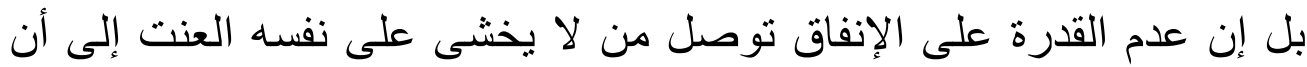

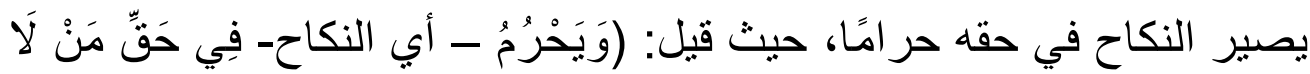

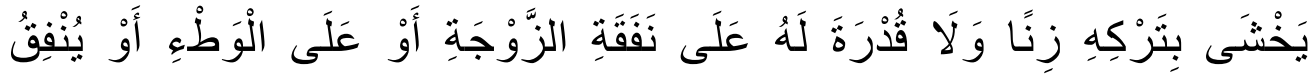

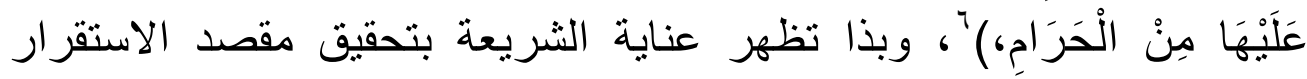

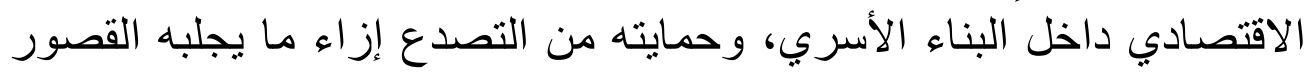

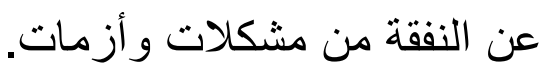

1 ـ التفسير الوسبط للقر آن الكريم، د. محمد سيد طنطساوي، دار نهضــة مصـر للطباعـة و النشـر

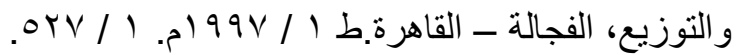

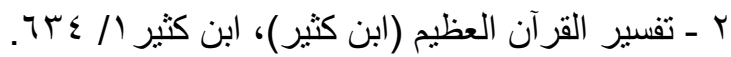

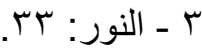

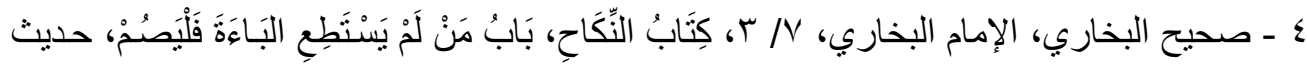

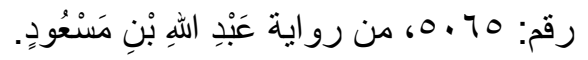

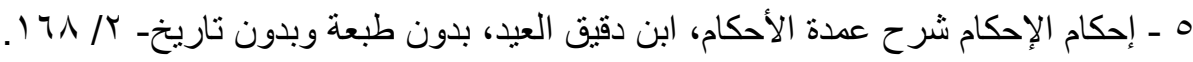

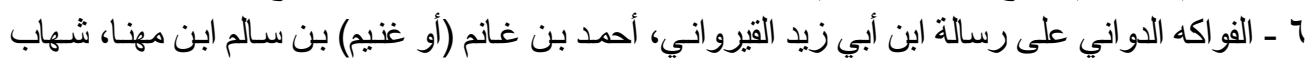

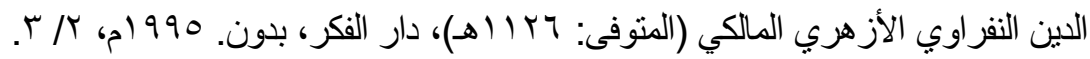


من مقاصد الدين الإسلامي تحقيق سلامة المسلم في دينه، بما يضمن له عيشًا طيبًا يبتغيه في رضا - الله سبحانه وتعالى - وإن تخلف عن أسبابه تبدل حاله إلي شقاء وتعاسة وضنك عيش.. وما نلحظه من مظاهر الفقر والحرمان وقلة الأرزاق، والتي ربما تشكل أزمات أسرية يطال خطرها جميع أفراد

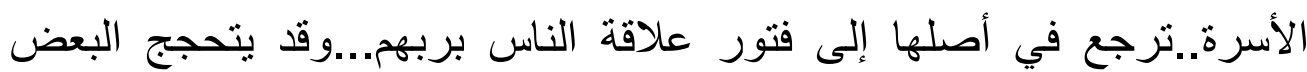
بضيق ذات اليد أو عدم القدرة على الكسب فيجنح إلى تحصيله بكل أسلوب

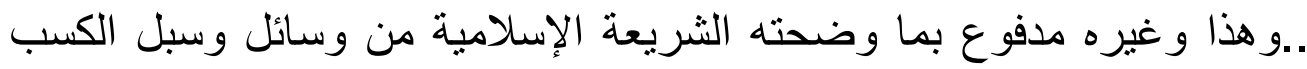

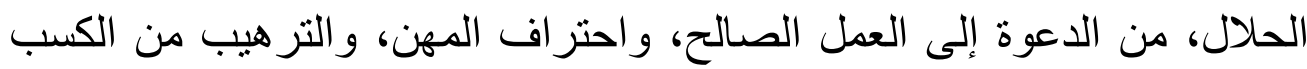
المحرم من الربا و الميسر والرشوة ... وواجب على العى المسلم أن يشتغل بما أحله

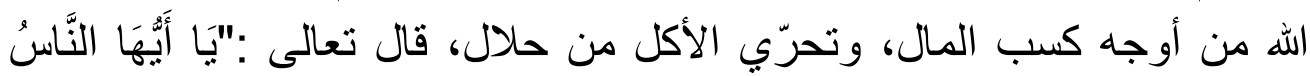

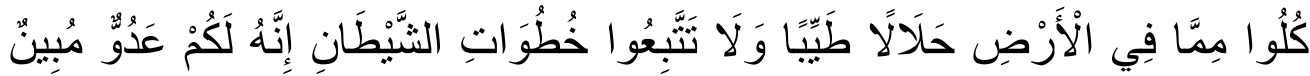

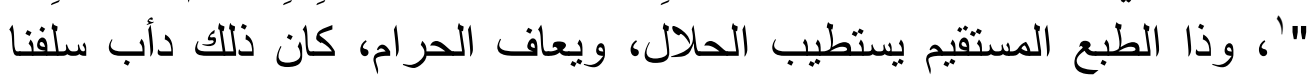

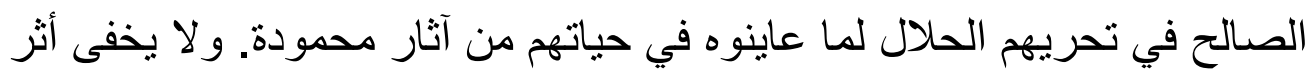

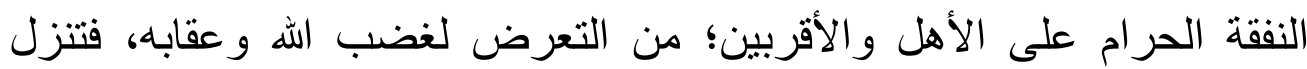
العقوبات الدنيوية من ضيق في الرزق، ومحق البركة..وفي الآخرة عذاب أليم.

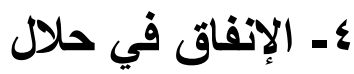

الزوج مطالب أن يكسب حلالا، وينفق على أهله من حلال اتقاء لسخط الله

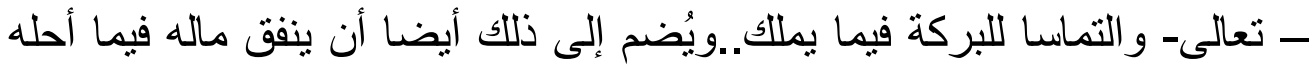
الله - تعالى - طلباً لما سبق، فإن من عوامل التردي الاقتصادي في الأسرة، قيام

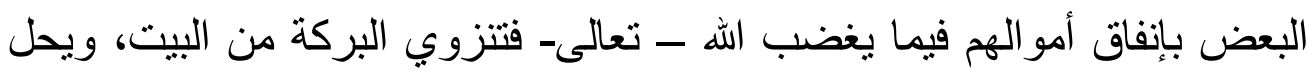

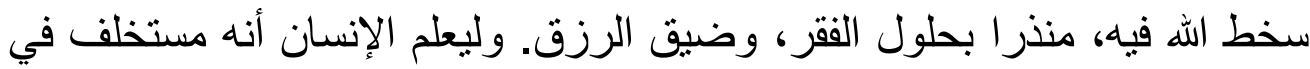

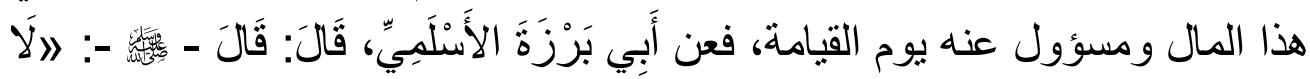

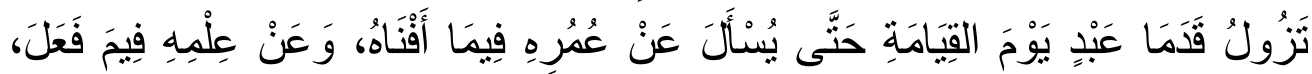




\section{$-7) \leqslant$}

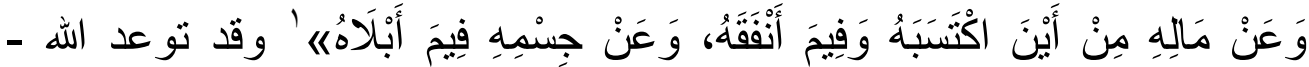

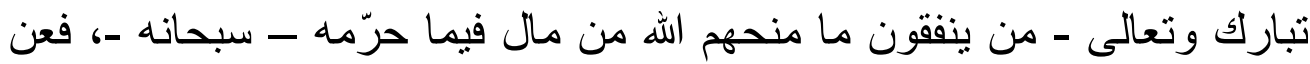

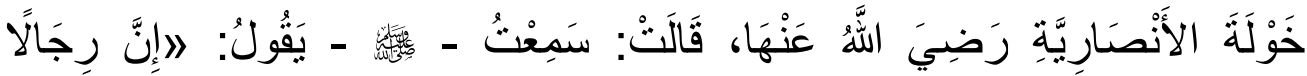

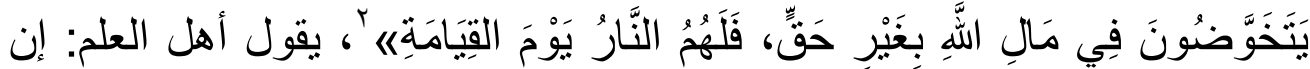

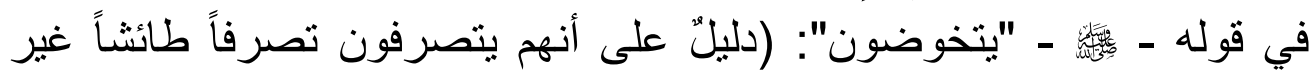
مبني على أصول شرعية، فيفسدون الأموال ببذلها فيما يضر، مثل من يبذل فئل

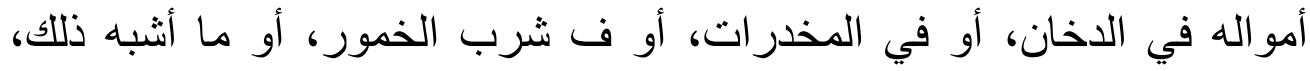

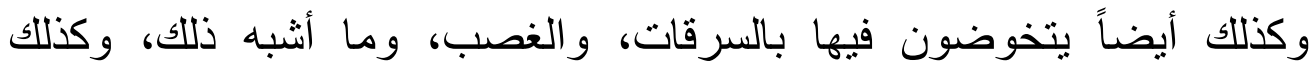

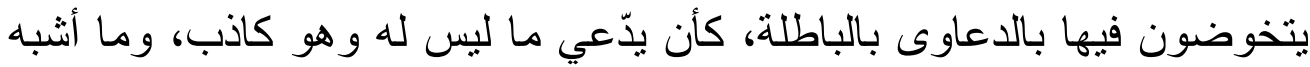
ذللك.)"، و إنفاق المال في هذه الأوجه هو من باب إضاعة المال الذي نهى عنه رسول الله

\section{تحديات الاستقرار الاقتصادي الأسري:}

توجد بعض الأمور تمثل تحديًا للاستقرار الاقتصادي الأسري، ولادئ وليس

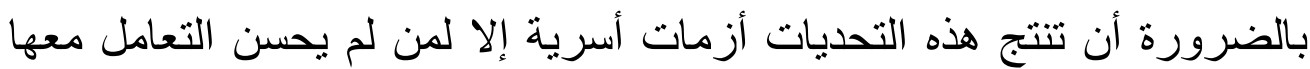

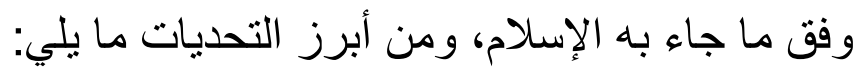

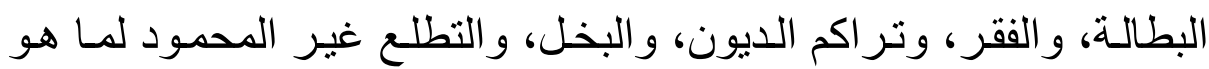

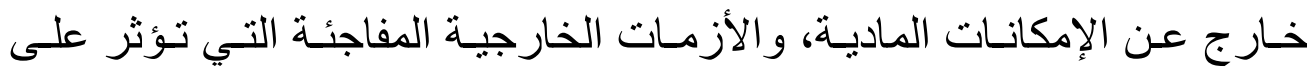
الوضع الاقتصادي للأسرة.

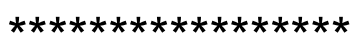

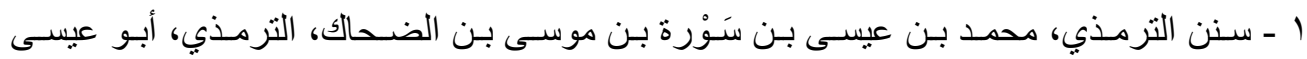

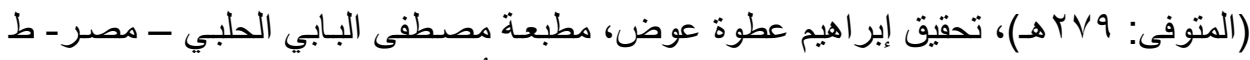

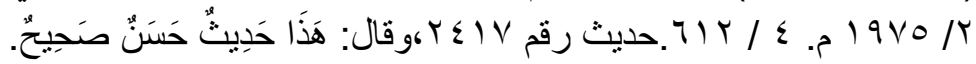

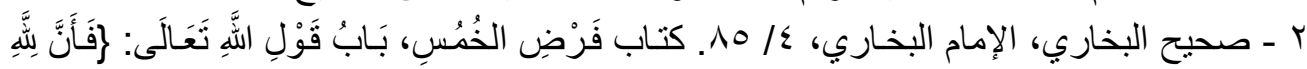

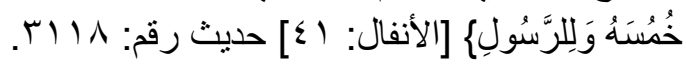

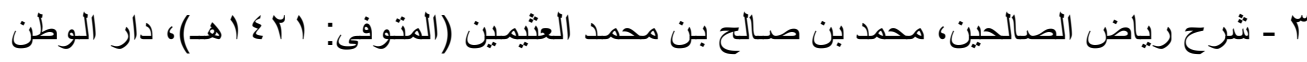

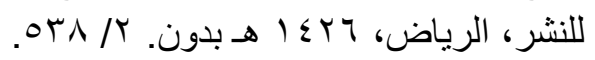




\section{المبحث الثاني

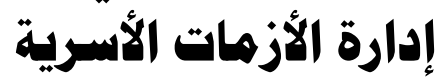

المطلب الأول: أسباب الأزمات الأبرات الأسرية

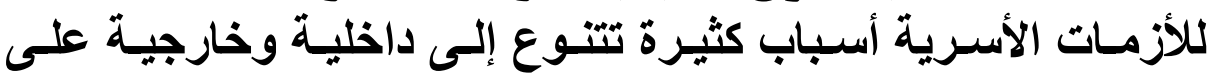

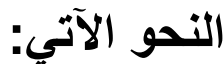

أولاً: الأسباب الاخلية للأزمات الأسرية:

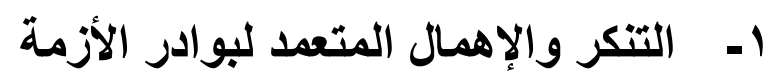

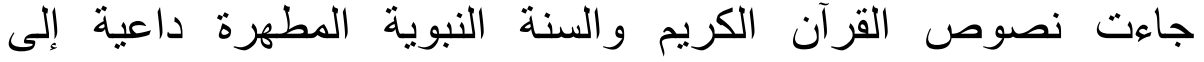
المسارعة في إنجاز الأعمال، والقيام بها خير قيام، وحذّرت من التهان التسويف

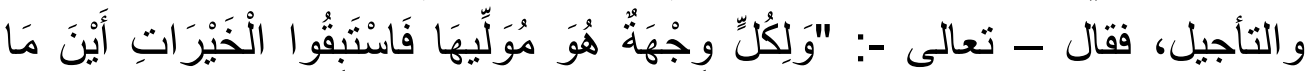

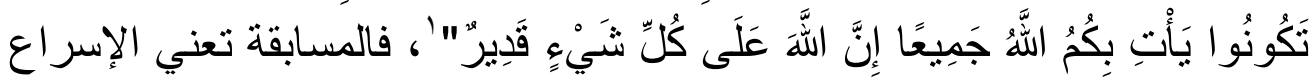

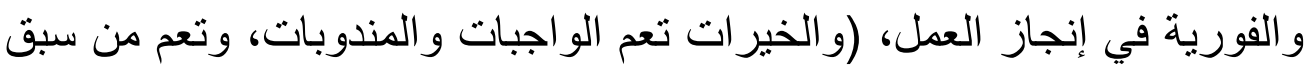

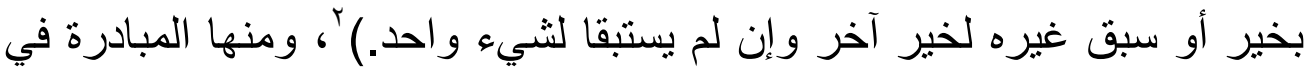

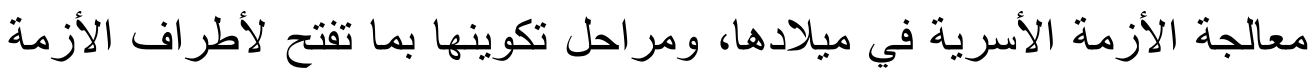

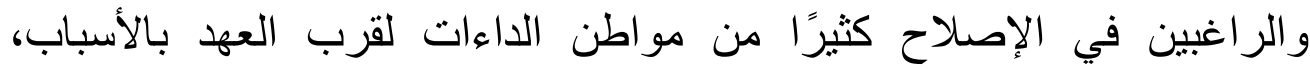

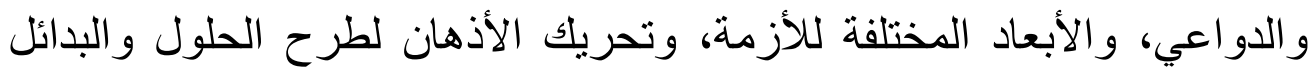

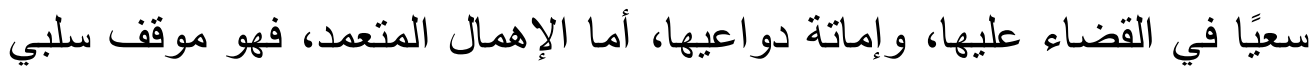

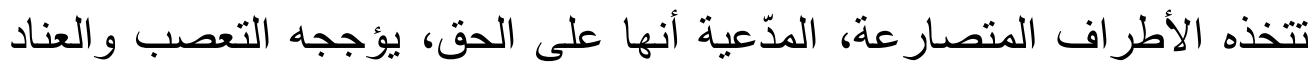

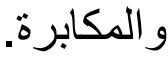
ويأخذ هذا الإهمال صورًا عدّة، منها: - الاعتقاد بأن الولوج في الأزمة

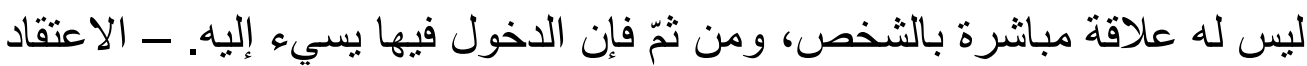

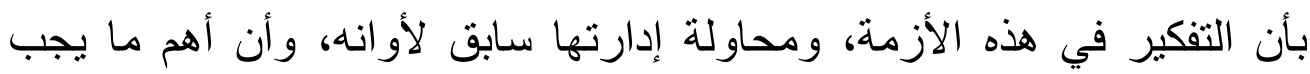

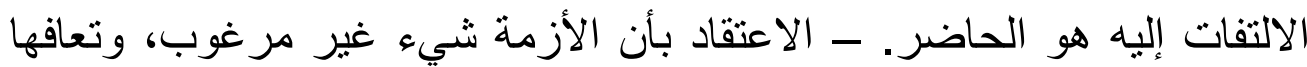

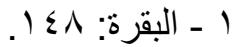

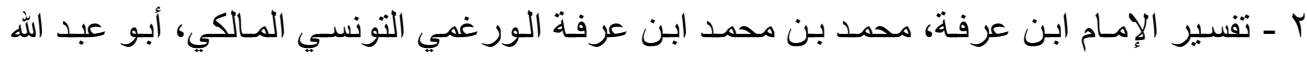

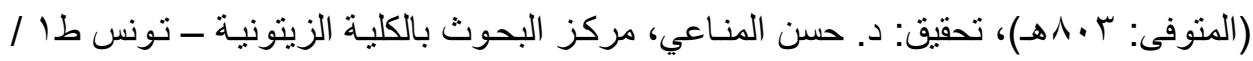


النفوس، ومن ثمّ يلجأ الفرد للهروب التلقائي من المواجهة. ويقرب من هذا

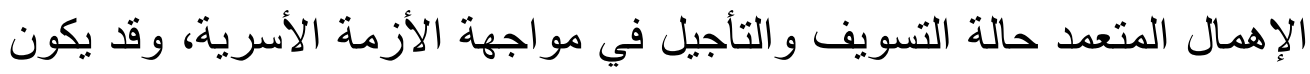
سببه ضعف الثقة بالنفس، والخوف من الفتل عند الإقدام على خطوة إيجابية، فتكون النتيجة تطور الأزمة، وعدم القدرة على الاحتواء إلا بشق الأنفس.

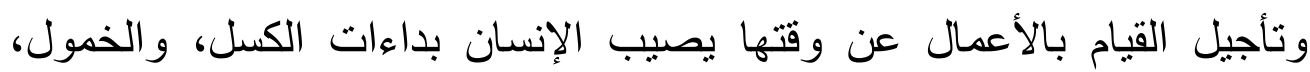

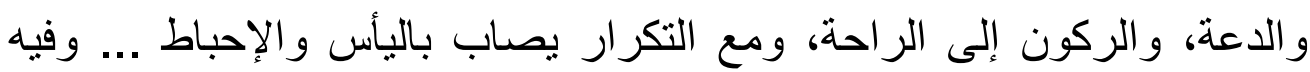
كذلك إيقاع الضرر بالآخرين، فقد يتخيل المرء أن النه الأزمة تعنيه وحده فيؤجل

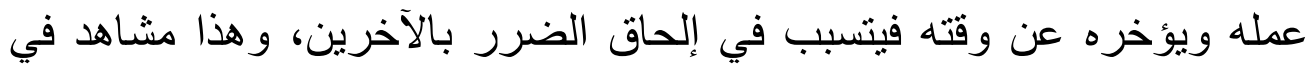

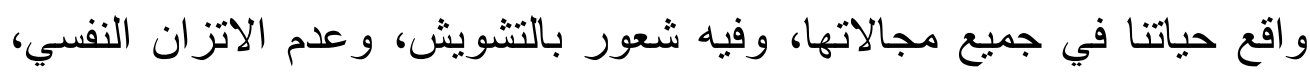

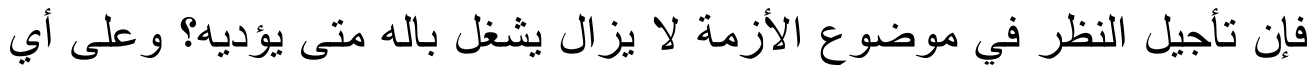
نحو؟ ويظل هكذا حتى يخرج الوقت، وتغرق الأسرة في آثار الأزمات المهلكة.

\section{r- الإفراط في سوء الظن.}

نهى الإسلام عن الظن الذي لا يغني من الحق شئًا، لقيامه على على غير دليل

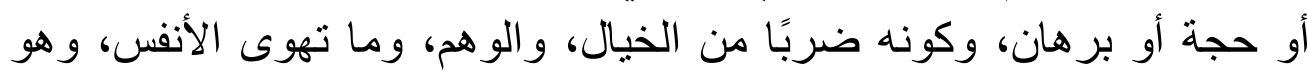

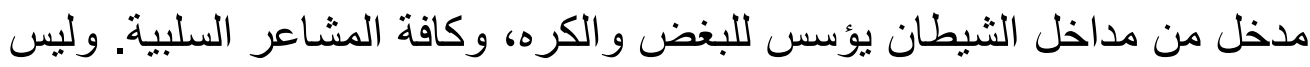

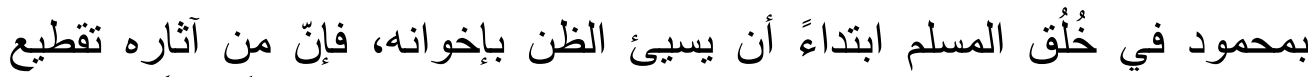

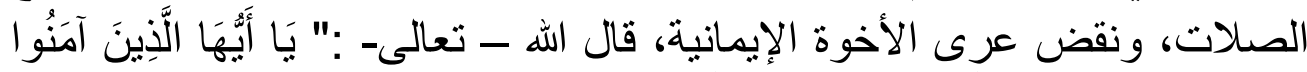

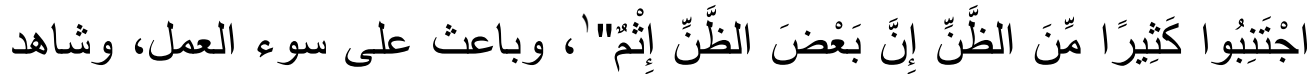

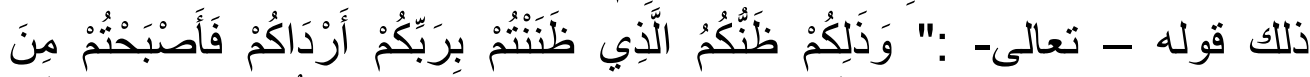

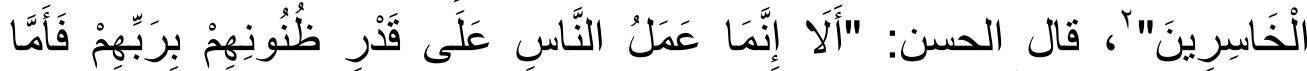

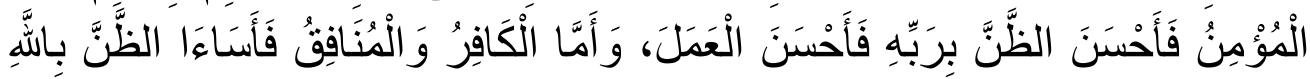

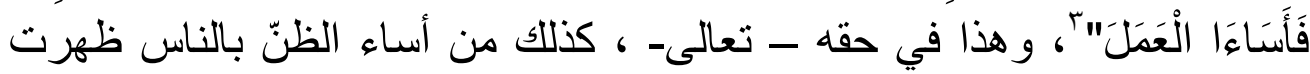

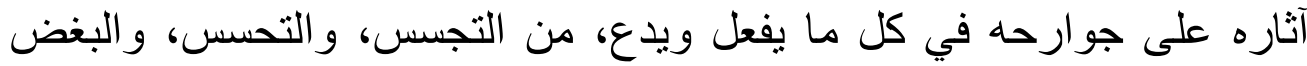

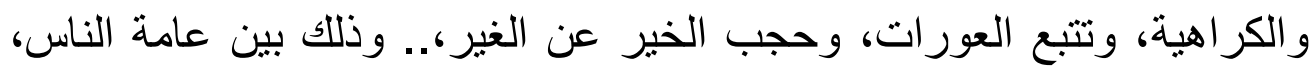
وقد يحدث ذللك في المؤسسة الأسرية، حين تصدر من أحد أطرافها تصني تصرفات

$$
\begin{aligned}
& \text { ا }
\end{aligned}
$$

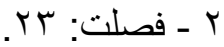

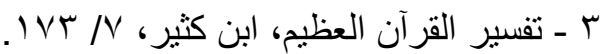


وسلوكيات تحمل الطرف الآخر على رؤية الأمور على غير حقيقها، ويأخذها

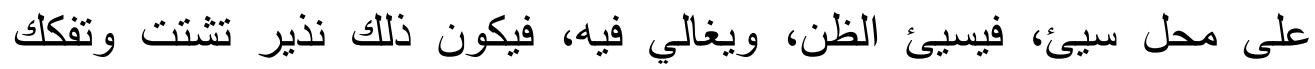

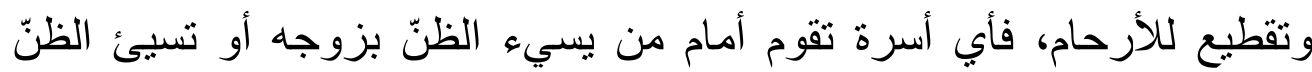

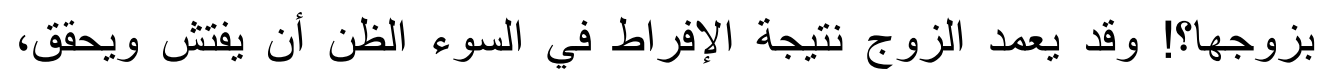

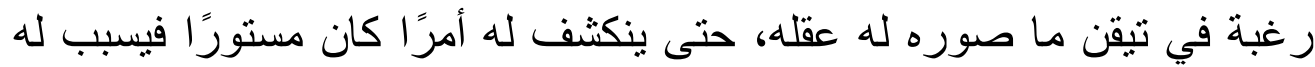

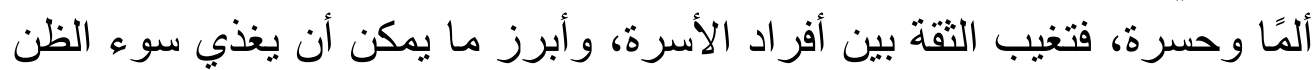

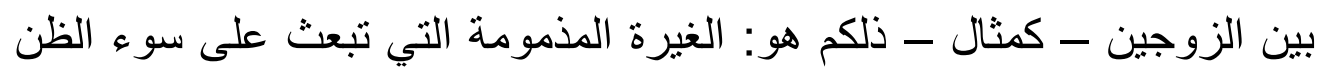

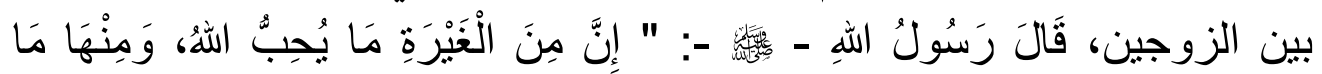

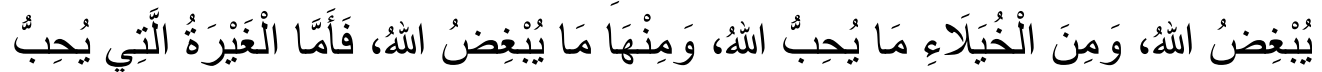

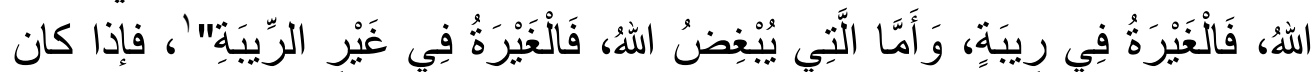

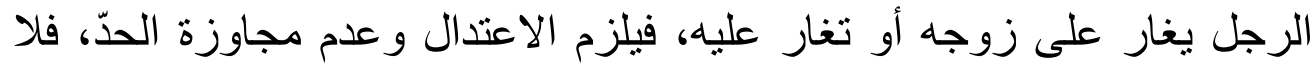

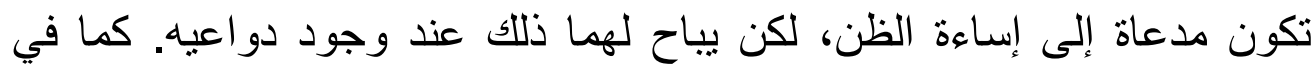

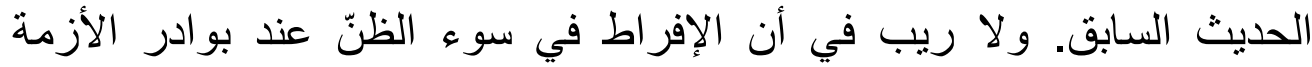

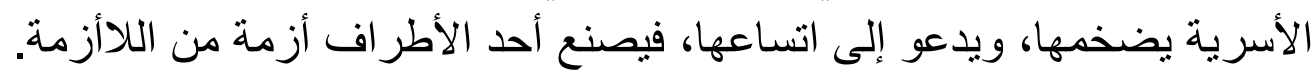

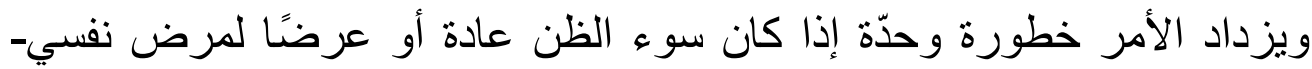

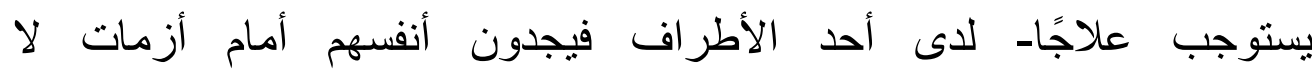

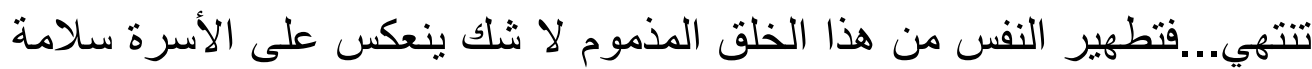

$$
\begin{aligned}
& \text { و أمنًا و استقر ارًا وخلوًا من الأزمات الأسرية. }
\end{aligned}
$$

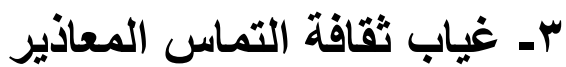

التماس المعاذير للخلق دالٌ عل كمال العقل، ورقة القلب، وباعث على التى

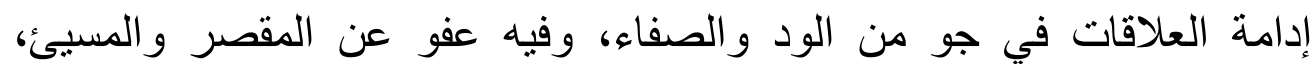

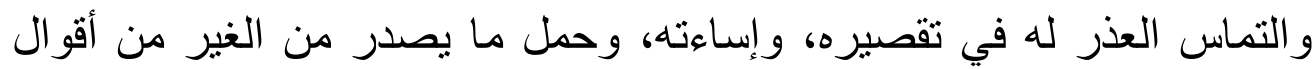

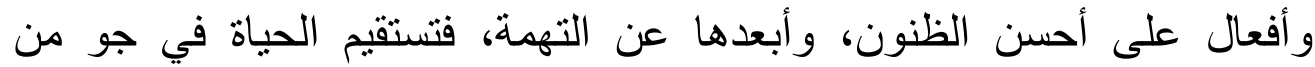

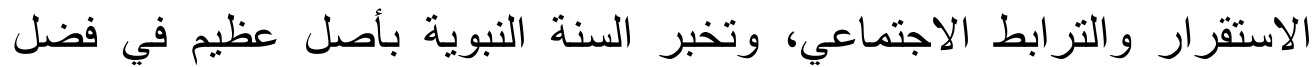

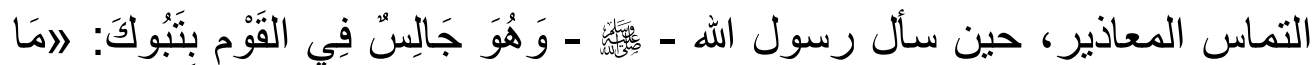

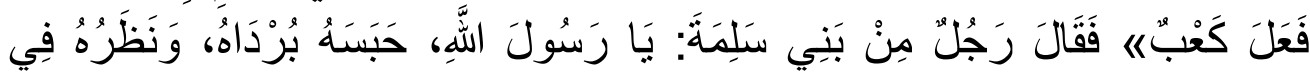

1 ـ مسند الإمام أحمد بن حنبل، أبو عبد الله أحمد بن محمد بن حنبل بن هلال بن أسد الثيباني

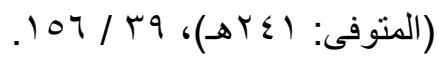


$-7) \wedge$

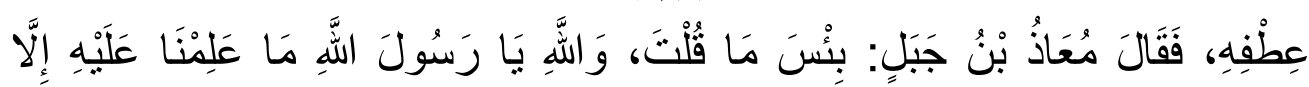

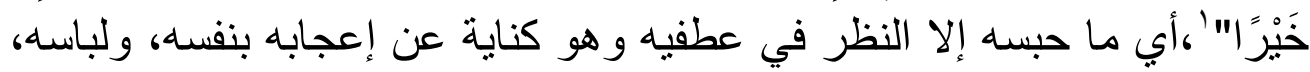

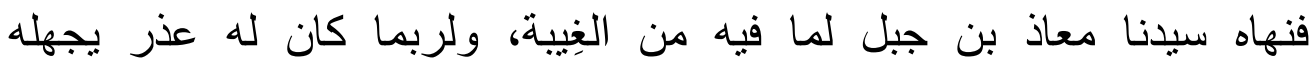

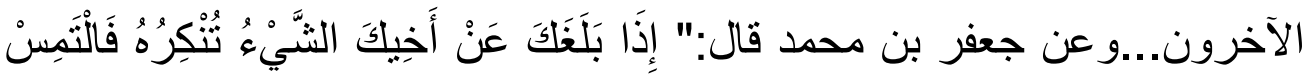

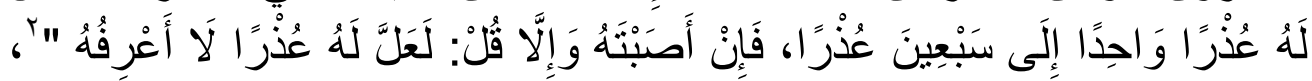

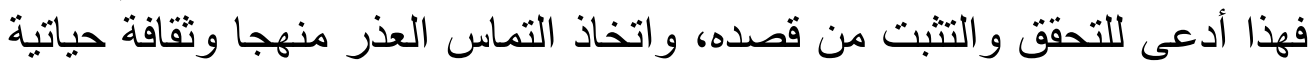
تبقي على العلاقات وتوثق عر اها حتى تصير طبعا وسجية للمسلم، يقول أمير

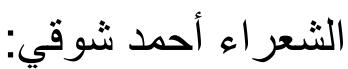

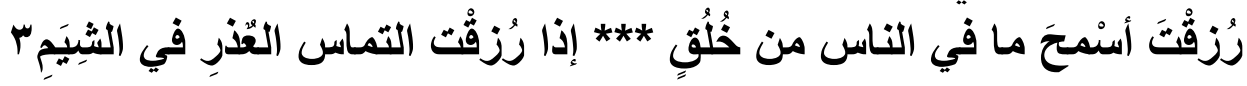

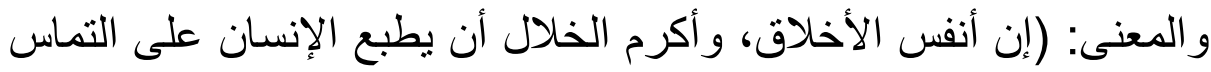

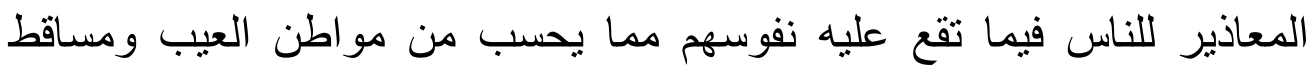

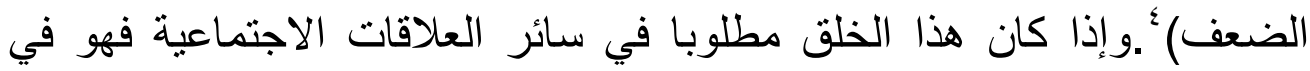

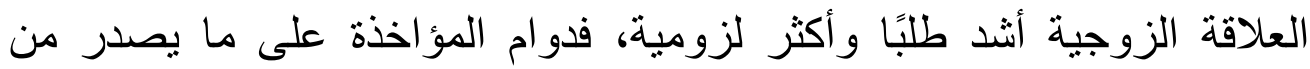
تقصبر من أحد أفراد الأسرة، و المبالغة في المحاسبة عليه يوتر العلاقة الأسرية، ويكثر النفور، ويقضي على نقاء النفوس، وسلامة الصدور، و المرء بطبعه ولفه

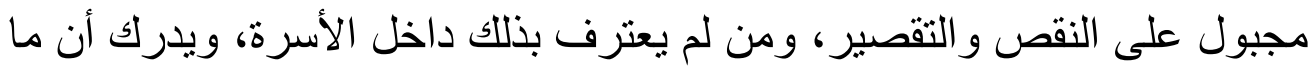

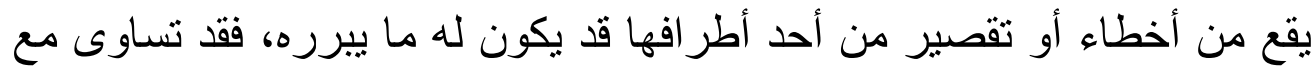

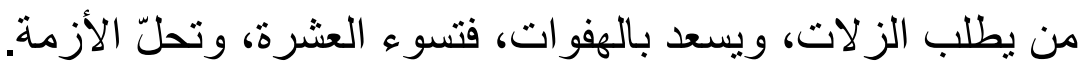

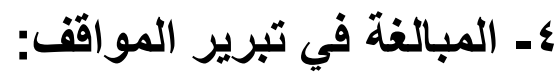

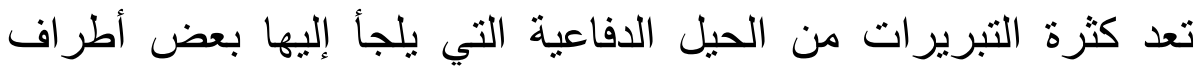

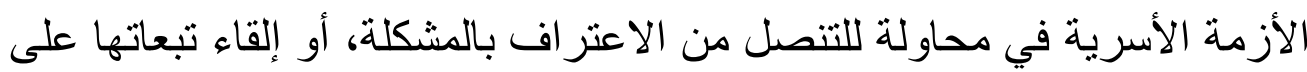

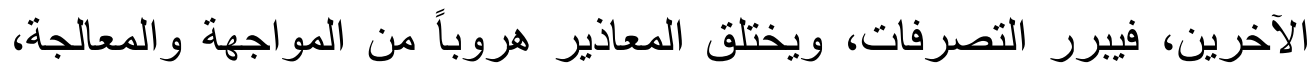

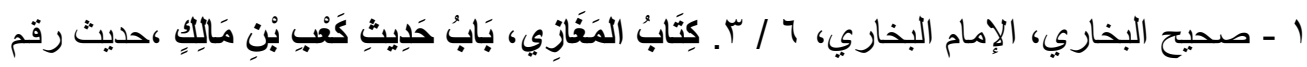
. $\leqslant$ १ᄉ

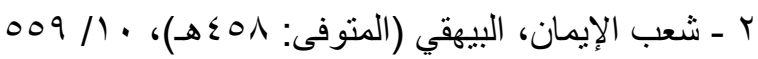

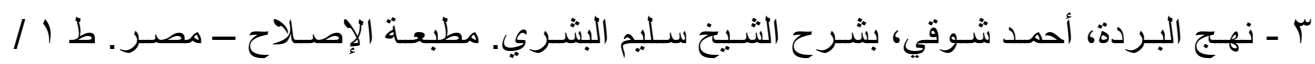

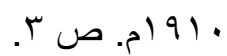
ـ ـ المصدر السابق ص זّ، ع. 
مغرقًا في افتعال الأكاذيب التي قد يعتقدها تسكينًا، وتهدئة لأوضاع معينة، أو أو التها

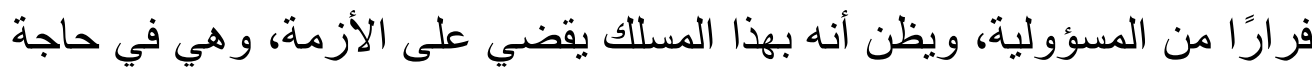

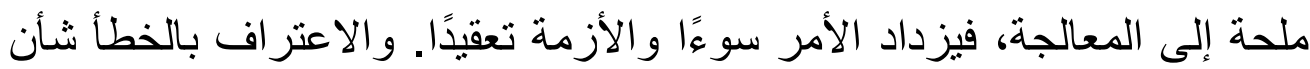

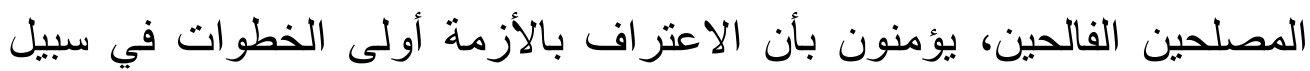

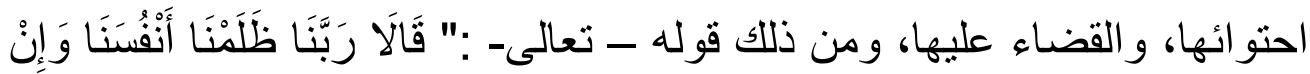

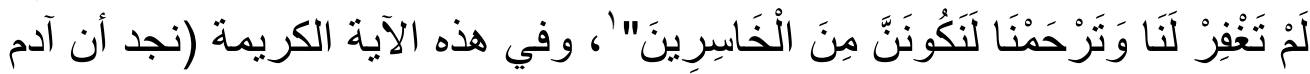

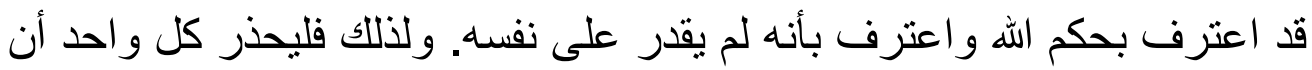

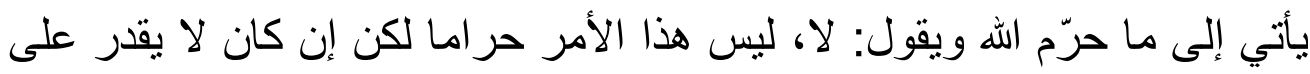
نفسه فليعترف ويقول: إن ما حرم الله حرام. لكني غير قادر على هلى نفسي. وبذللك

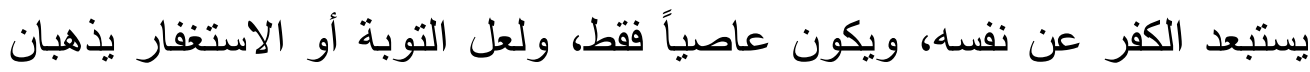

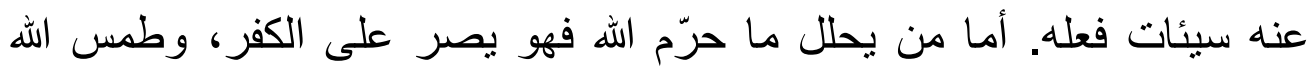

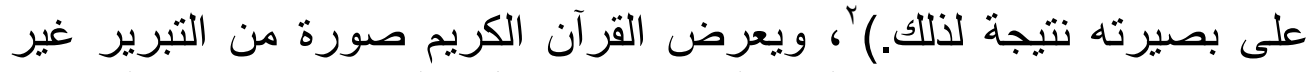

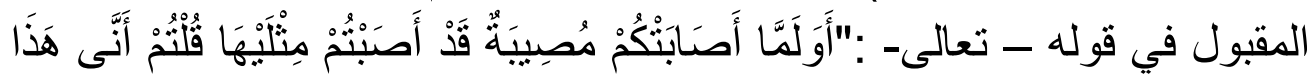

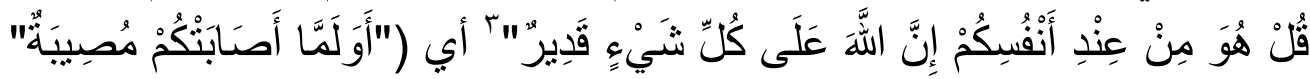

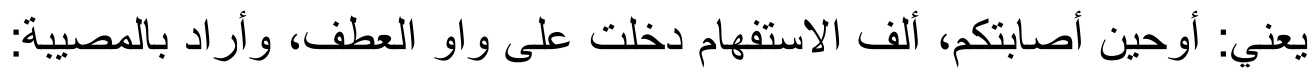

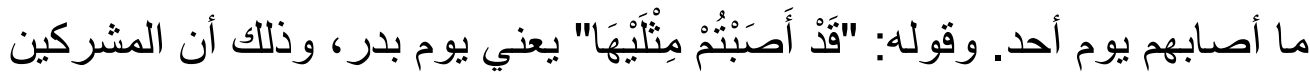
قتلوا من المسلمين يوم أحد سبعين، وقتل المسلمون منهم يوم بدر سبعين وأسروا

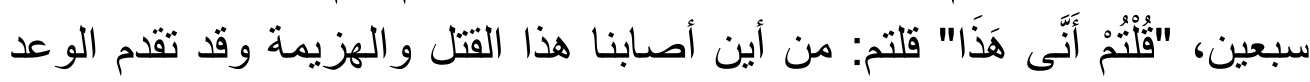

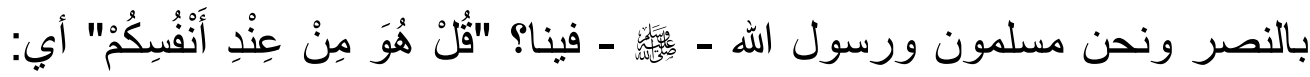

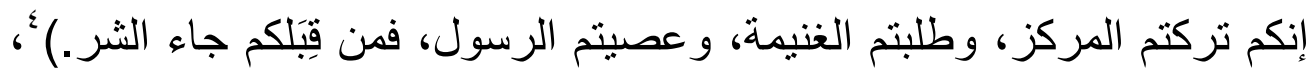

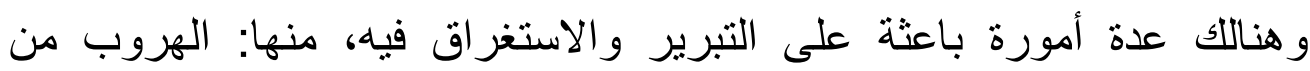

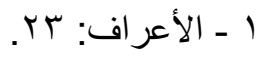

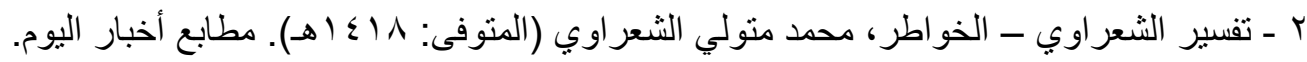
YT 10

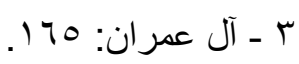

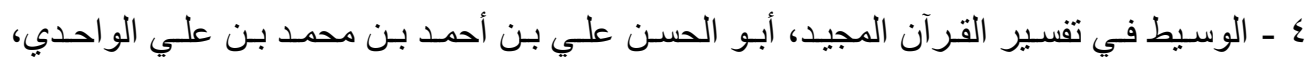

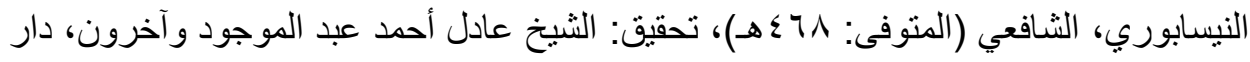

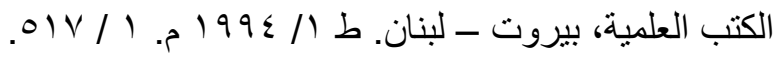


الأزمة، أو التخلص من تبعاتها، والتشبث بالرأي، والتعصب، و والكبر، و وعدم

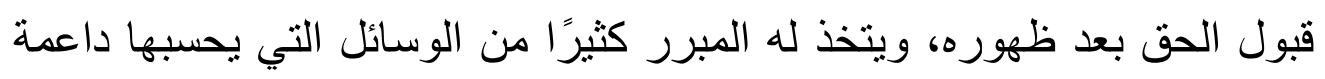
لموقفه، كالكذب، والتعويل على ظروف ولى وضغوظ الحياة، والاحتجاج بالقدر..وكلّ ذلك مؤد إلى حدوث أزمة أسرية تطول فيها مدة الاحتواء

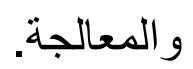

\section{ثنانياً: الأسباب الخارجية للأزمات الأسرية : الأبة}

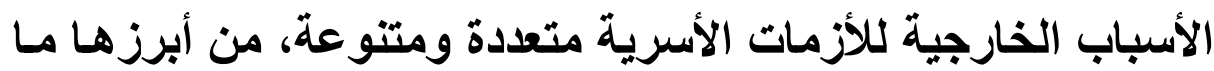

\section{1 - التخبيب}

التخبيب شأن العاملين على إفساد العلائق بين الناس لاسيما بين المرء

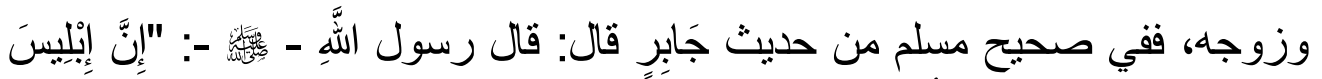

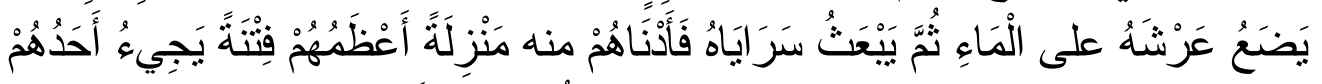

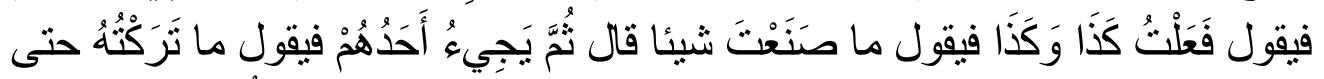

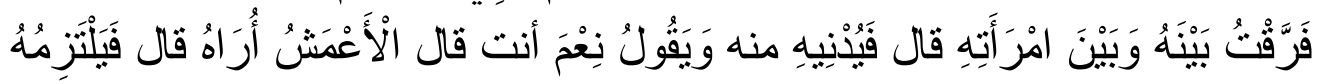

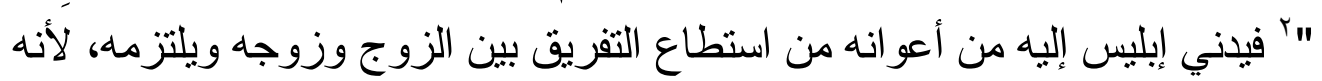

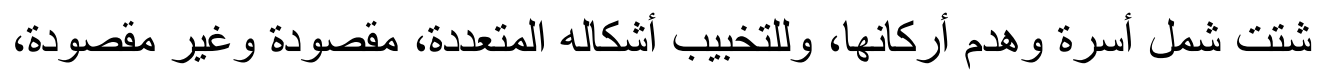

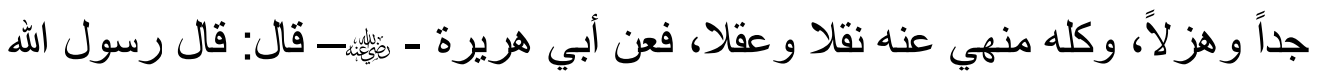
زوجها، كمن بسعى في الإصداح بين زوجين، فيعد إلى بيان مساوئ أحد الطرفين

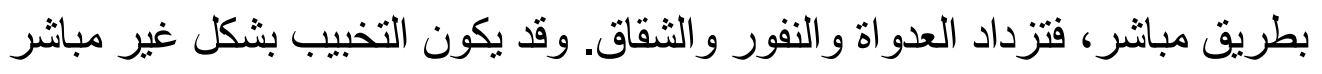

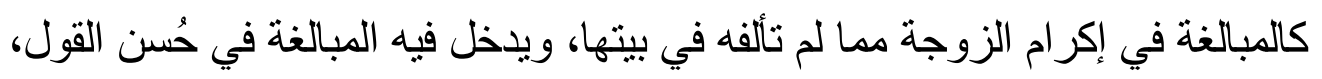

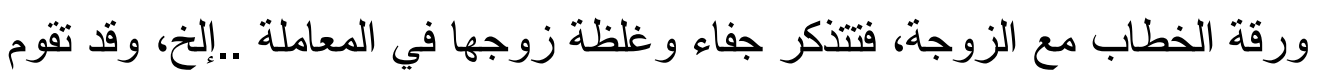

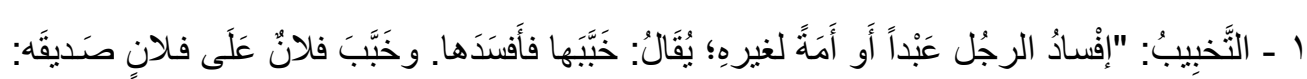

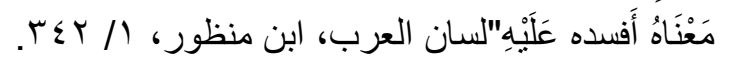

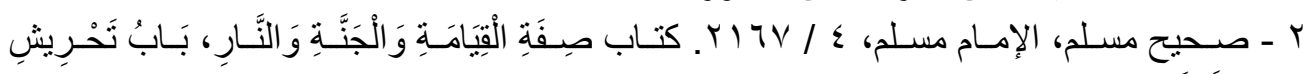

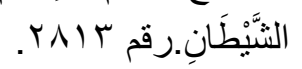
r - المستدركِ على الصحيحين، لأبي عبد الله الحاكم النيسابوري المعروف بابن البيع (المنوفى: 
بعض شرار النساء بالتخبيب على نحو يظهر لبعض الرجال ما بفتقده من زوجه،

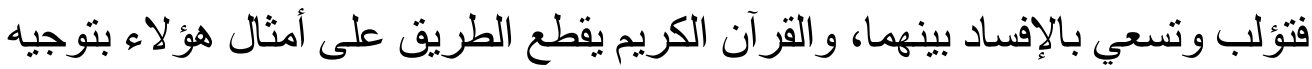

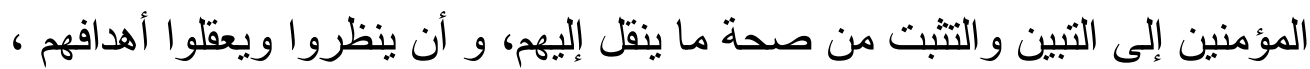

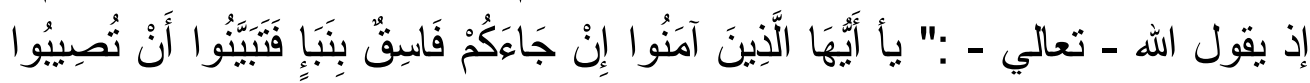

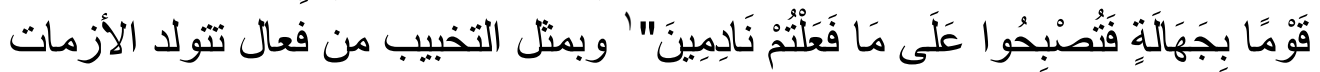
الأسرية.

\section{ب الأفكار المستوردة}

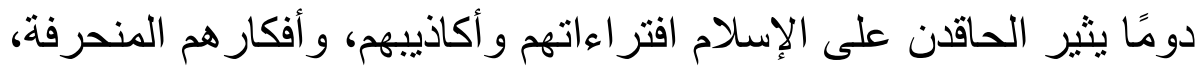

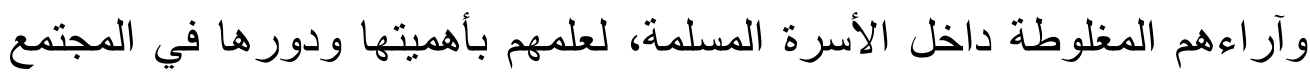

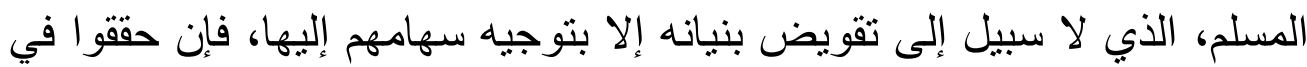

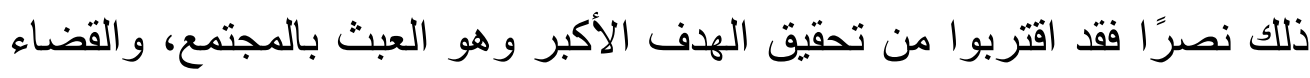
على قيمه الإسلامية، و لا شك في أنهم حققو ابعض الهدف في ذلك اللك الميدان، حيث

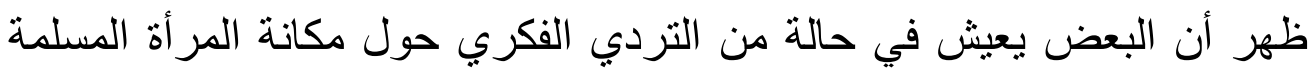

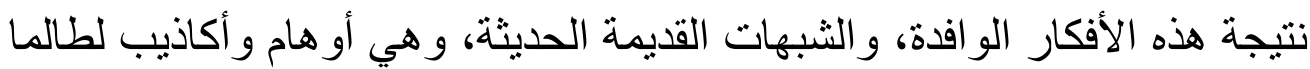

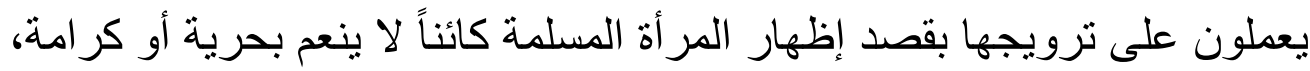

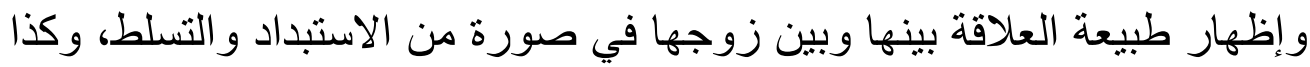

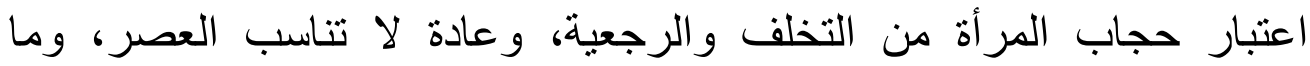

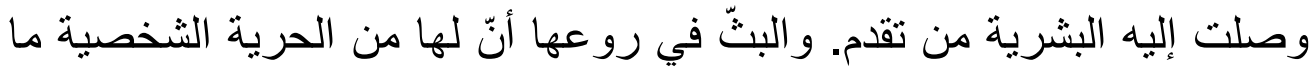

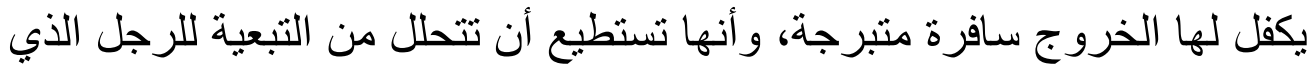

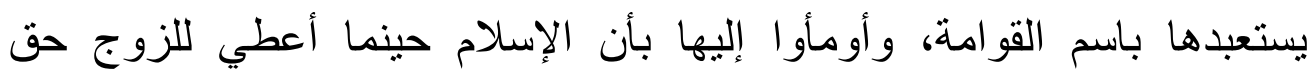

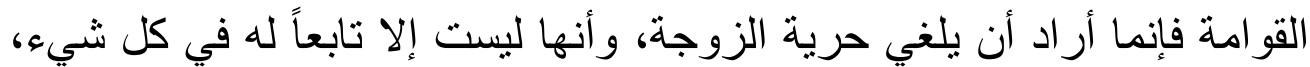

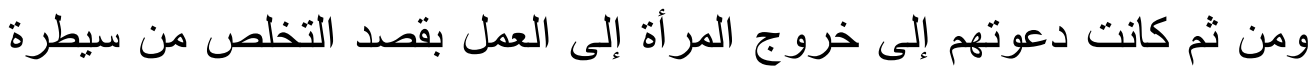
الرجل و إذلاله لها ـ كما يزعمون - سواء كانت في حاجة إلى هذا العمل أم أم لا.

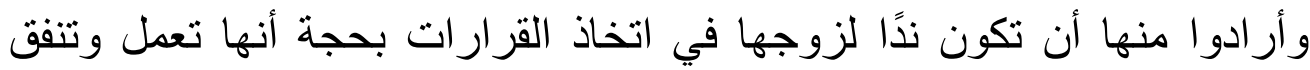

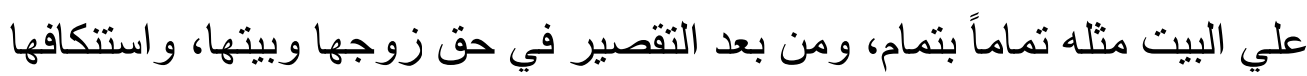

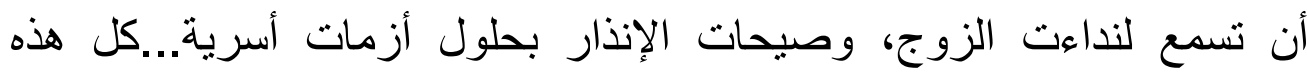


-TYY

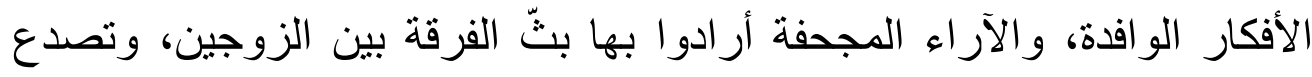

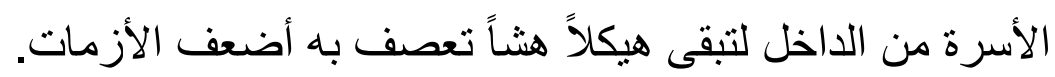

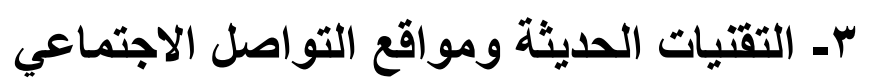

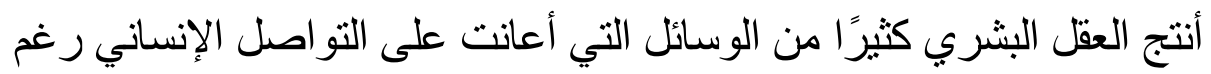

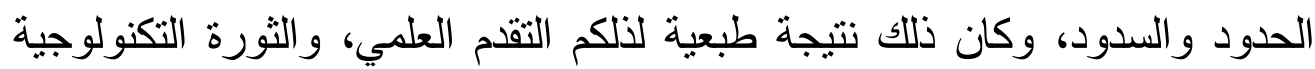

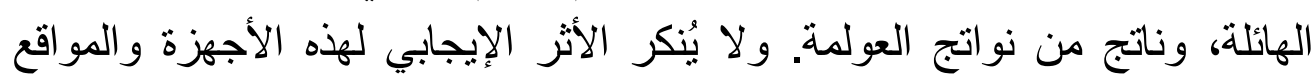

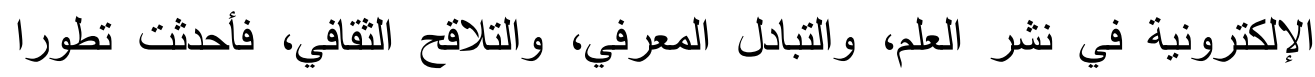

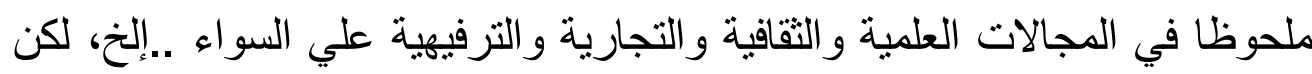
أيضا لا يُنكر ما لها من سيى الأثر على الأفراد والمجتمعات حين تستهلك أعمار

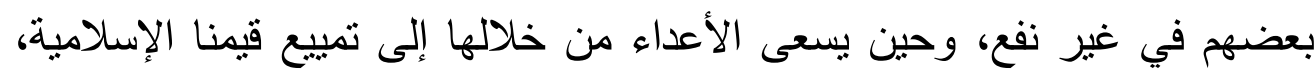

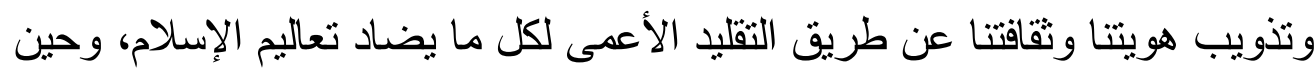

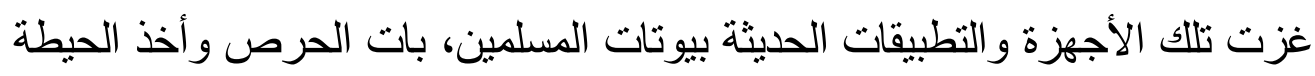

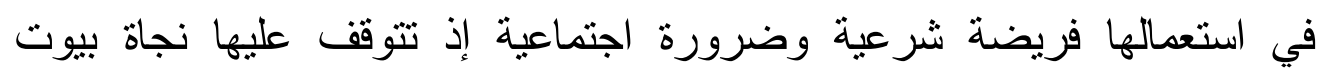

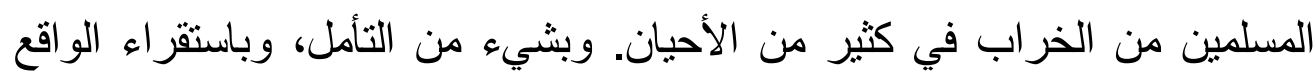

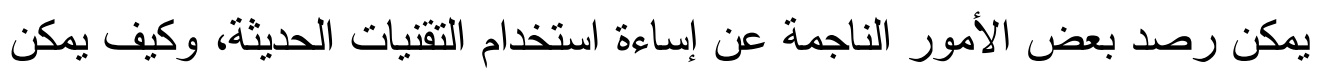

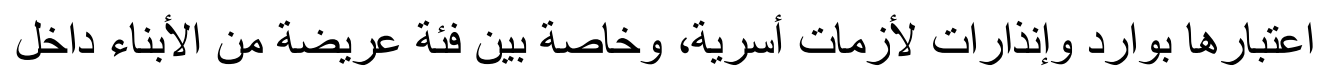

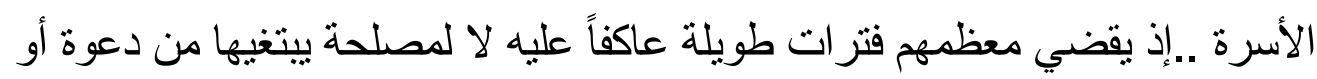

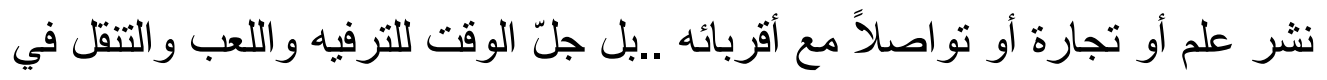

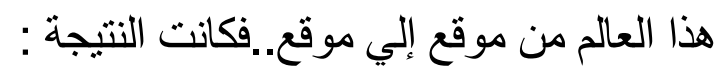

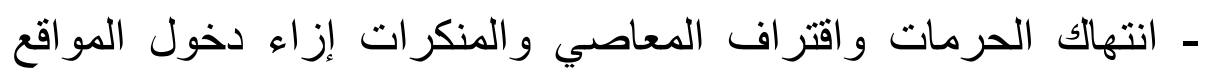

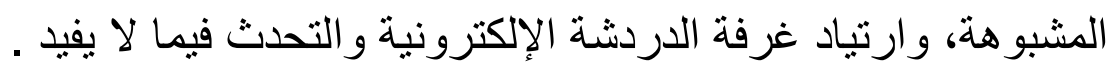

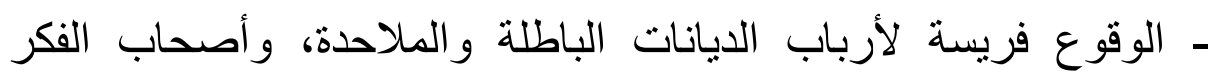
المنحرف، ودعاة الإرهاب الالكتروني في ظل أمية دينية أصابت كثيراً

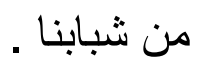
- ارتفاع معدل حالات الطلاق الناجمة عن العلاقات غير المشروعة بين الرجال و النساء، الذين تعارفوا وتو اعدوا علي الثكبة العنكبوتية.

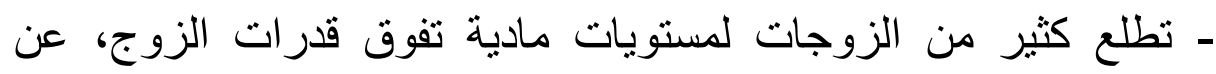

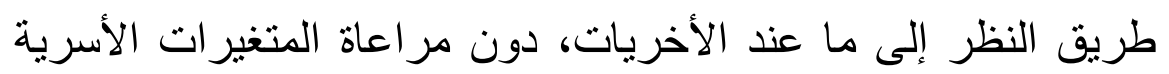


- المكسب الخبيث لمن يتاجرون بعقول وطاقات أبنائنا، بفتح مقاهي الإنترنت ودلالتهم علي المواقع التي لا خير فيها. - إضاعة الوقت وهو رأس مال الإنسان وعمره الذي بتفلت دون فائن فائدة

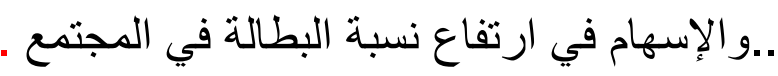

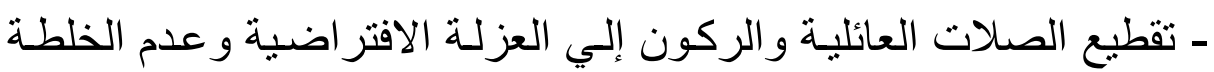
الإيجابية، حتى وُجد ما يسمى بالخرس الأسري.

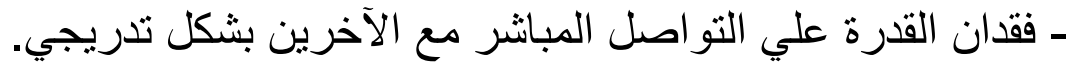

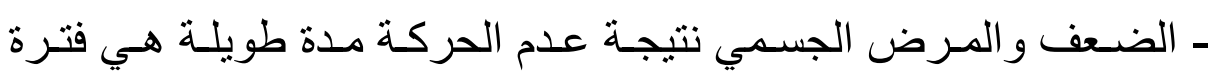
الانكباب علي الانترنت. ـ التردي الملحوظ في دعوة كثير من الثباب إلى الالتزام والعودة إلى تعاليم الدين نتيجة ما يجدونه على شبكة الانترنت من سبل الصد عن سن سبيل الله.

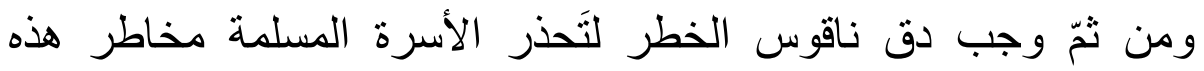

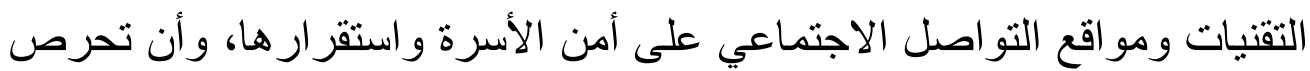
دوما على ما بينفها.

\section{ع - الخلطة الفاسدة.}

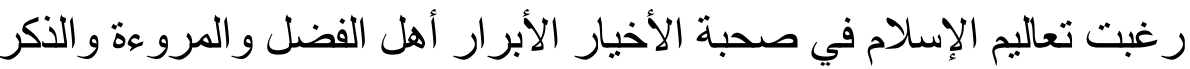

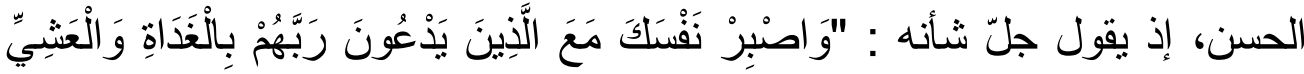

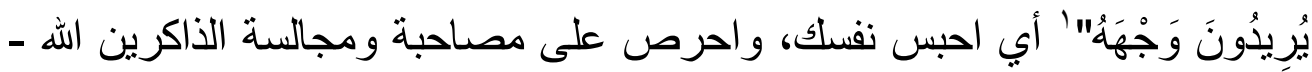

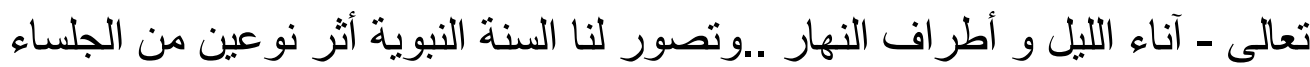

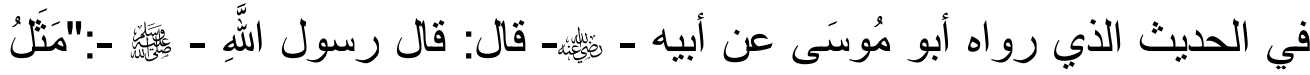

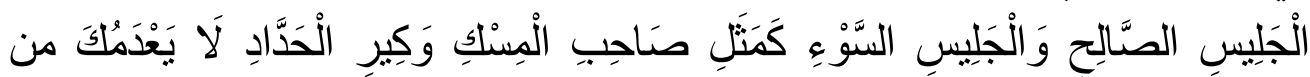

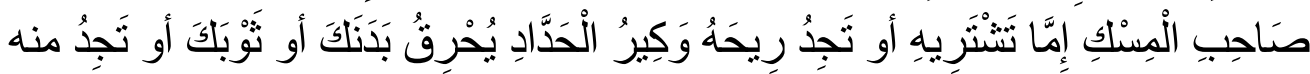

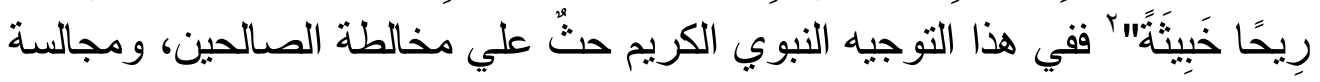

$$
\text { ו ـ الكهف: بر }
$$

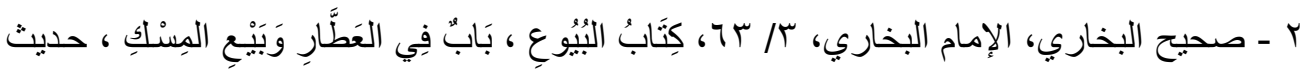


-7Y

أهل الفضل و الخير، تتتفع بمخالطتهم في دينك ودنياك، فإن لم تأخذ منهم ما تريد نقلوا إليك ما يريدونه للك من الخير و الفضل و الخلق الحسن، فلا بد أن يصييك منهم الخير

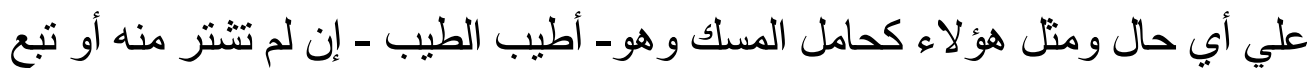

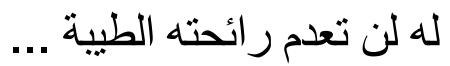
وفي المقابل: ينهانا الحديث النبوي عن مخالطة أهل البدع و الأهواء، و والهو

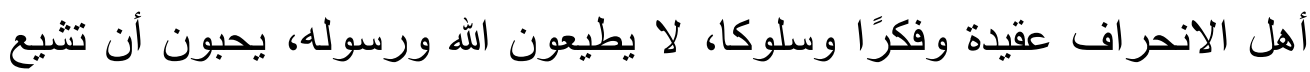
الفاحثة في الذين آمنوا، يقيمون علي الوقيعة بين الناس، وإفساد العلائق بينهم

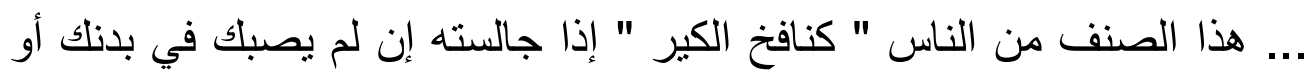
ثيابك وجدت منه ريحاً خبيثة ...وما أكثرهم في كل وقت وحين ...وما فسدت

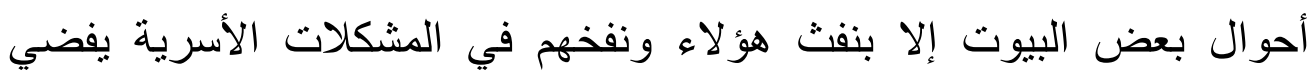
الزمبل لزمبله، و الجليس لجليسه، وتفضي الزميلة لزميلتها وتحكي لها أسرار

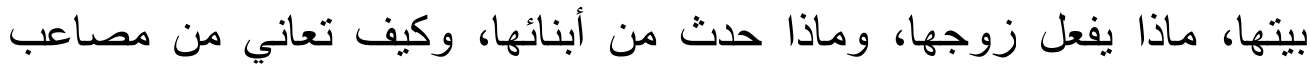

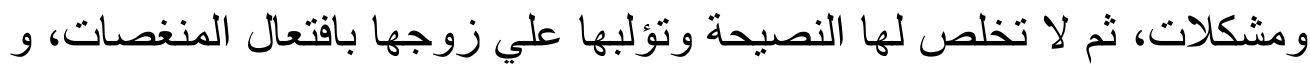

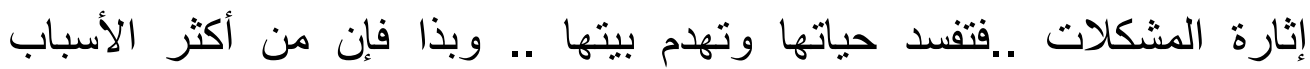

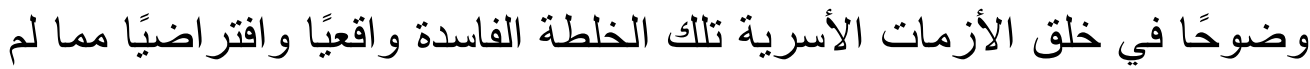
تشلم منه أغلب الأسر في وقتي الازئات الحاضر.

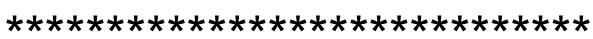

\section{المطلب الثاني: خصائص مدير الأزمات الأسرية}

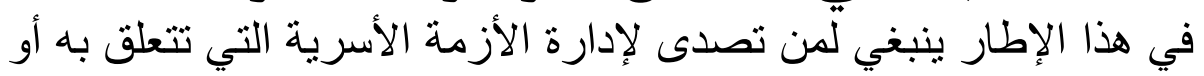
بغيره، مجمو عة من الخصائص و السمات، منها: اـ الموضوعية' في توصيف الأزمة و أقصد بذللك أن يكون مدير الأزمة موضو عياً في وصفه للازمة، بوديه بييان

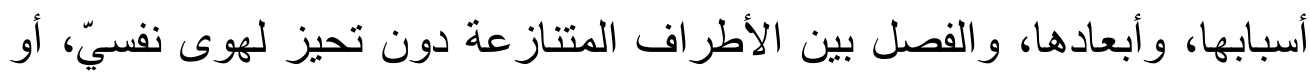

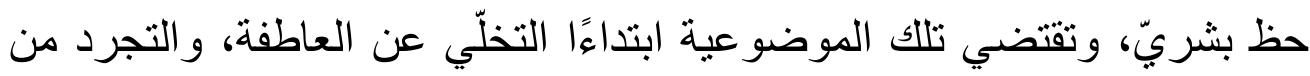

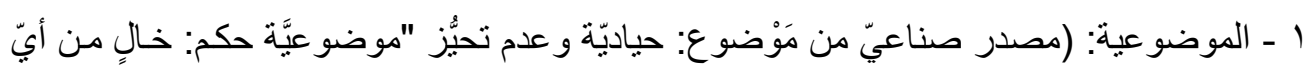

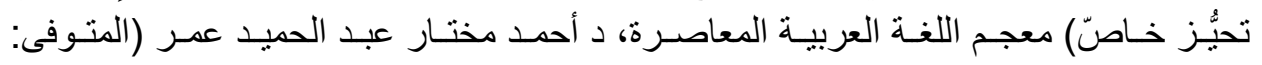

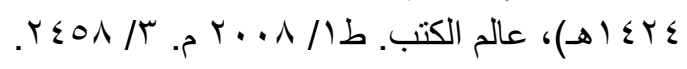


_TYO

رأي مسبق، و إفساح المجال لأطر اف الأزمة لإبداء حجتهم، ومناقتنها بأريحية،

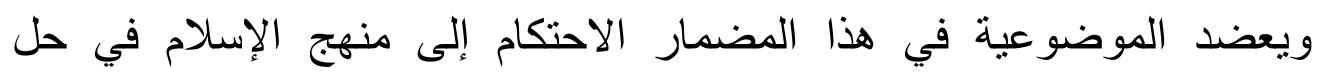
المشكلات و إدارة الأزمات، فالأصل أن نبحث في القرآن الكريم والسنة النبوية

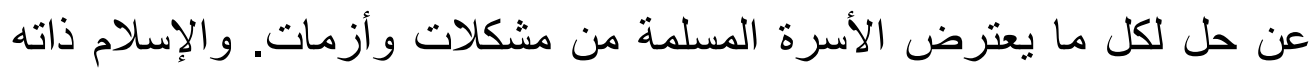

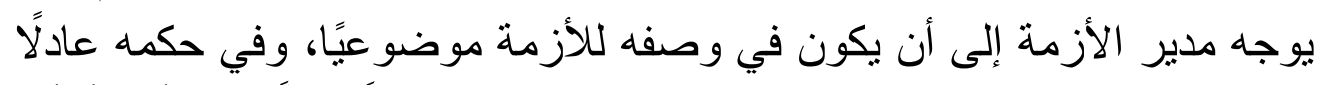

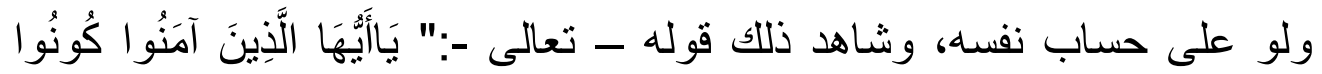

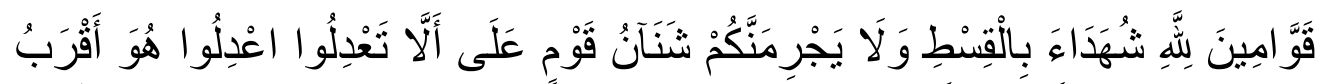

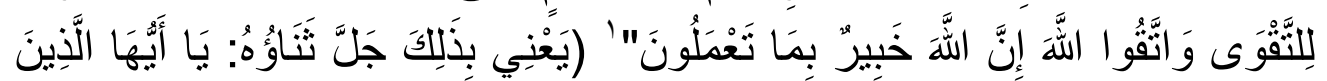

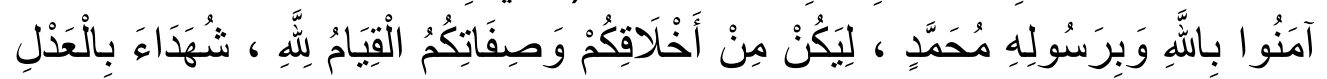

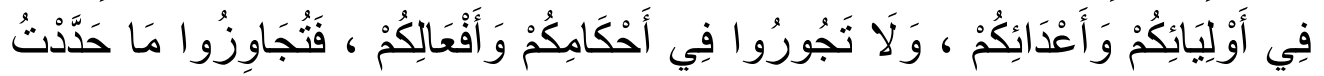

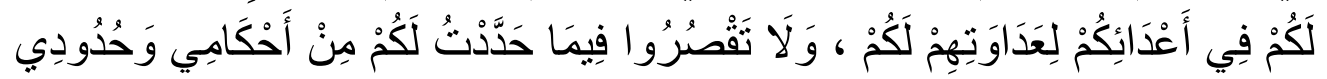

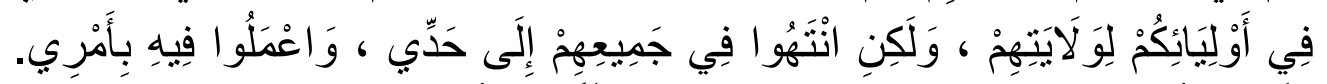

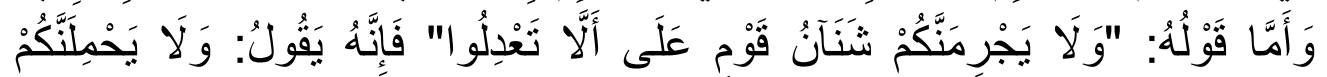

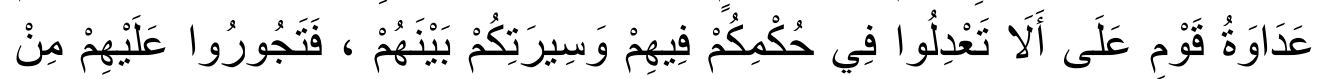

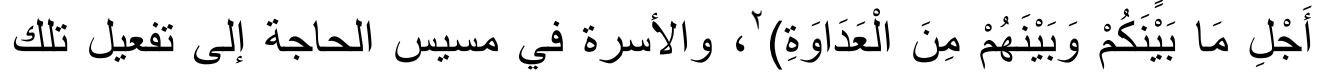

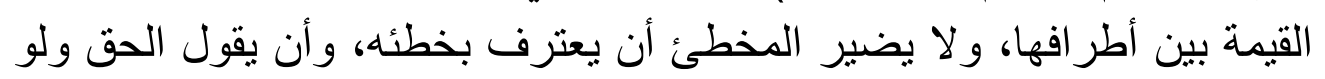

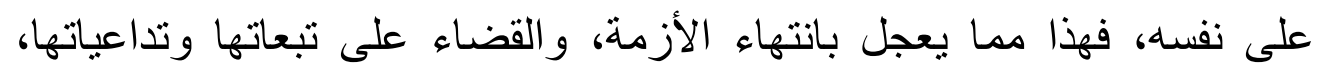

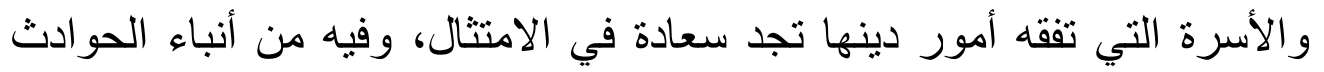

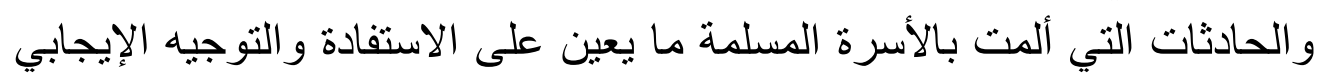
نحو إدارة الأزمات في شتى المجالات.

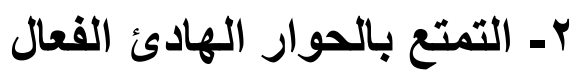

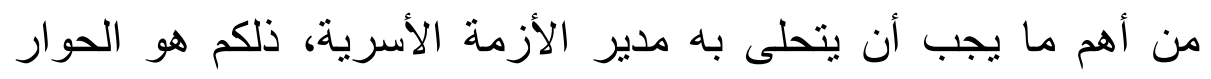

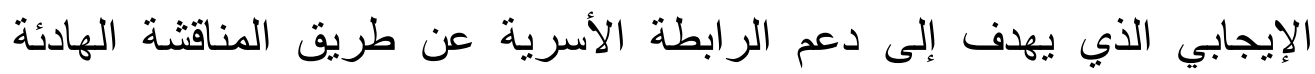
الهادفة، والبعد عن الحوار السلبي الذي يكون من طرف واحد، ويغلب عليه

1 ـ المائدة: A.

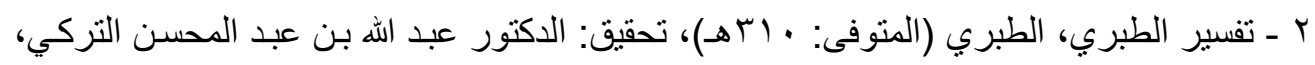

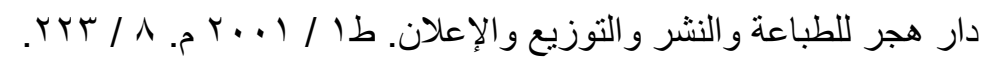


الاستبداد، ويؤدي إلى لاشيء في مجال الإصلاح الأسري، وأن يبتعد مدير

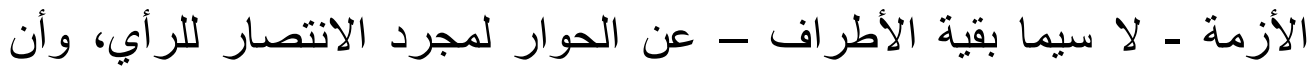

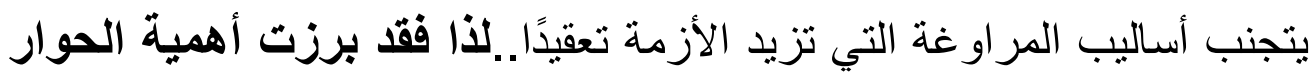

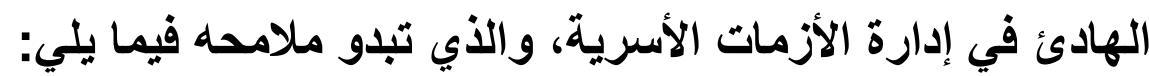

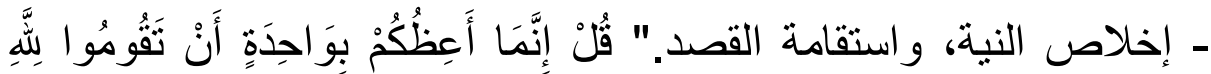

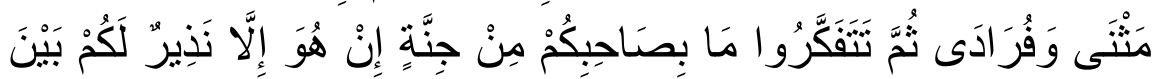

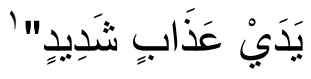

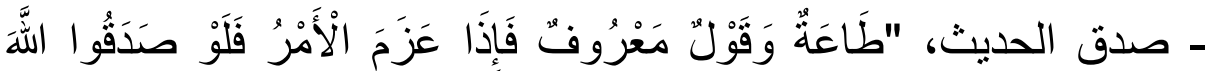

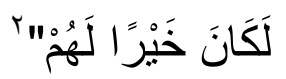

ـ التحلّي بالصبر ، وسعة الصدر .

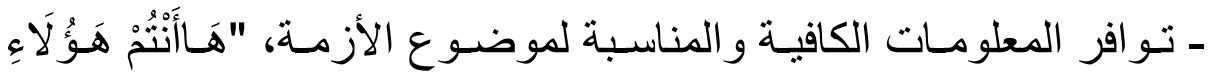

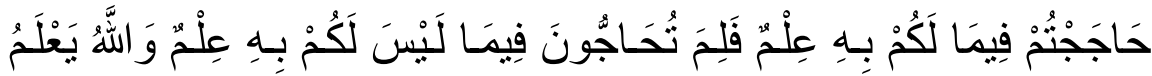

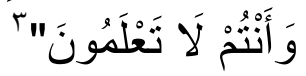

ــ النصح الخـالص، و إر ادة الخير للمنصوح الذي يمثنل طرفًا في الأزمـة.

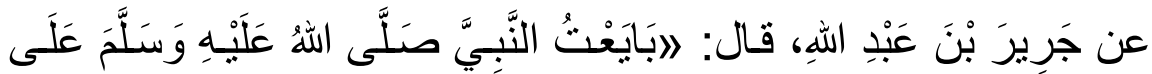

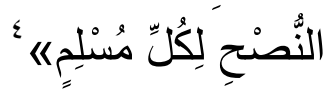

ـ امتلاك ناصية البيان للإفِصاح عن المقصود من الحوار باستخدام الألفاظ

$$
\begin{aligned}
& \text { التي لا يستغربها أطر اف الأزمة. } \\
& \text { ـ القدرة على مخاطبة العقل و الوجدان. }
\end{aligned}
$$

ـ تصدير الثقة بالنفس لدى أطرف الأزمة، للتعبير عن الر أي بحرية تامة.

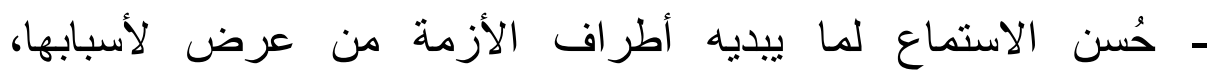
وتداعياتها، وكيفية احتو ائها.

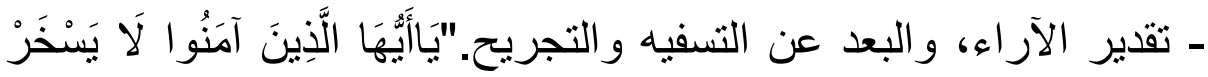


$-7 T V_{-}$

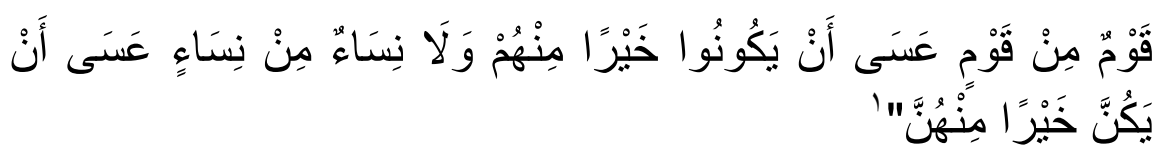

$$
\text { - التو اضع للاليل عند ظهوره. }
$$

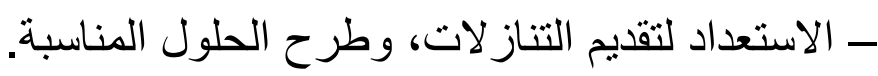

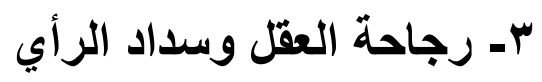

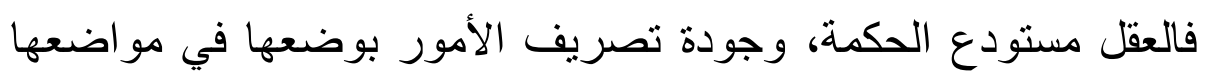

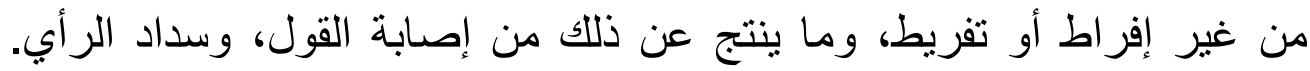

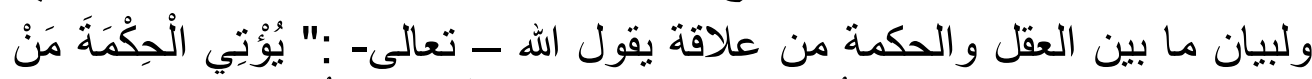

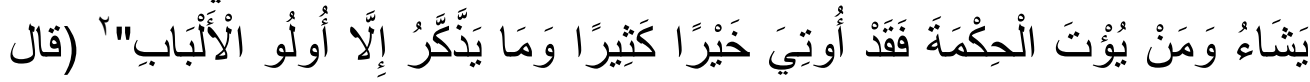

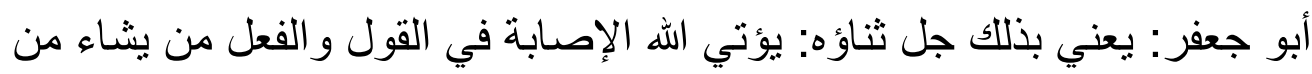

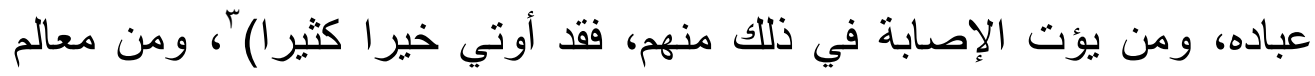

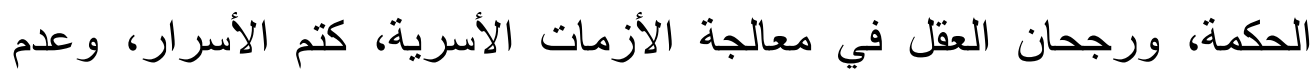

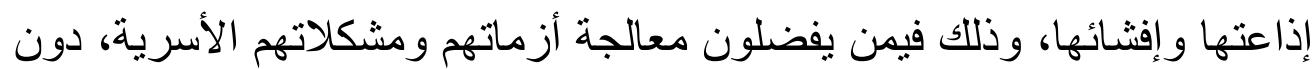

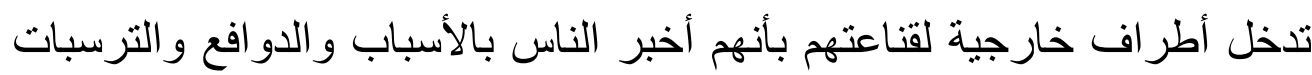

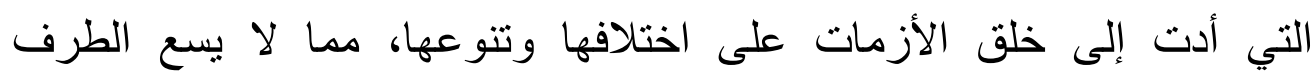

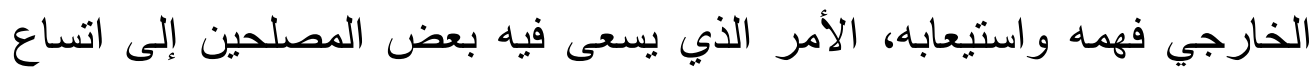

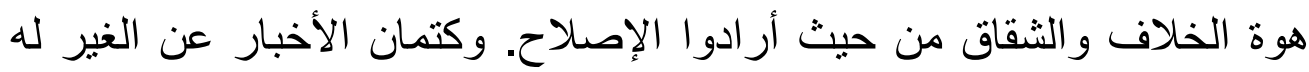

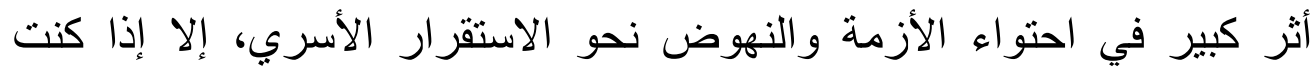

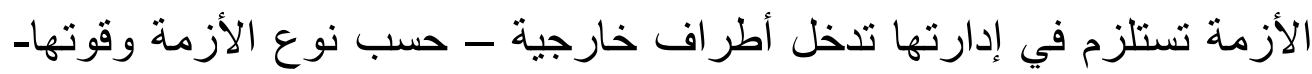

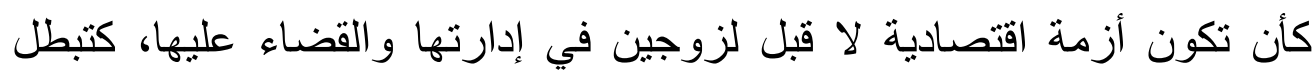

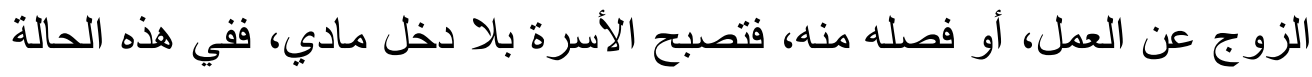

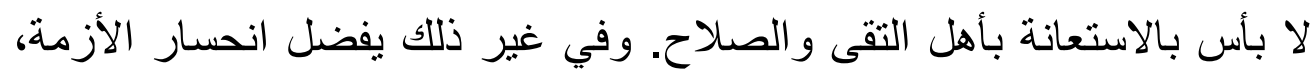

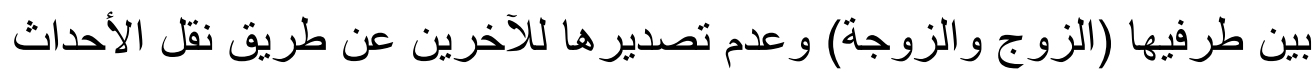

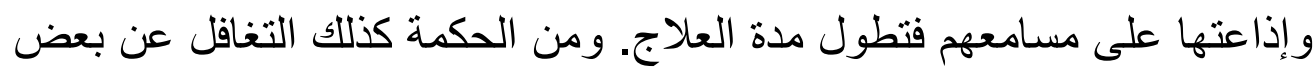

$$
\begin{aligned}
& 1 \text { ـ الحجرات: } 11 \text {. } \\
& \text { r - البقرة: }
\end{aligned}
$$
r - ب - جامع البيان في تأويل القرآن، الإمام الطبري، 10 ــ. 
-7YA.

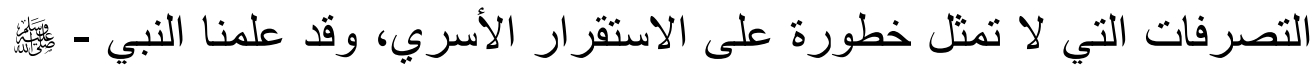

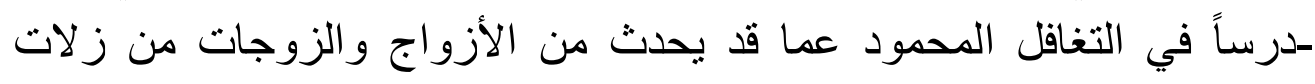
وهفوات، والتي يستحب التغافل عنها ضماناً لاستقرار الحياة الزوجية وبقائها،

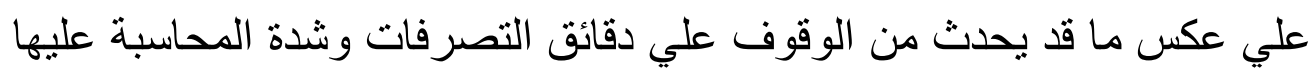

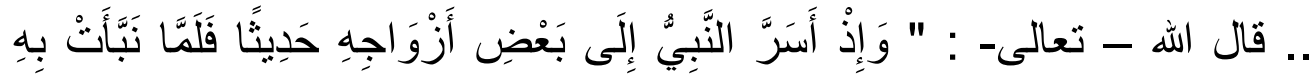

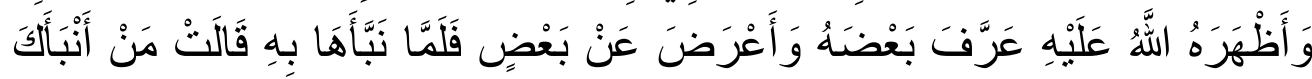

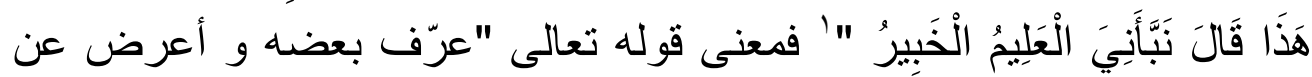
بعض" يعني أخبر حفصة ببعض ما قالته لعائشة وتغافل عن البعض العالى الآخر.

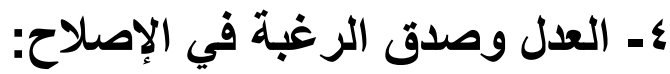

وتللك من أهم خصائص مدير الأزمة ـ كأحد أطر افها- يكون فيها مبرعًا

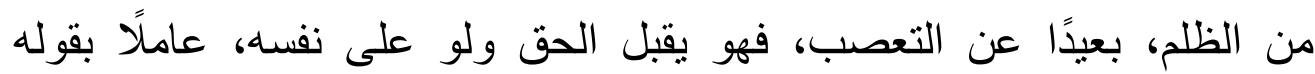

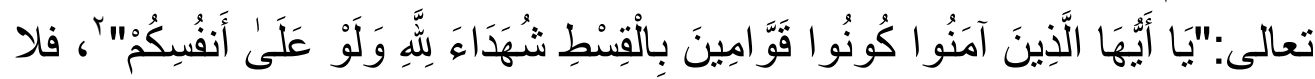

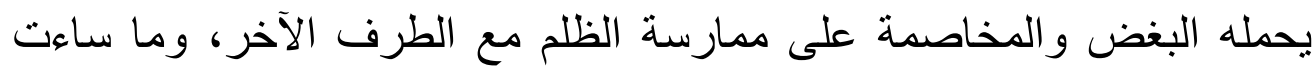

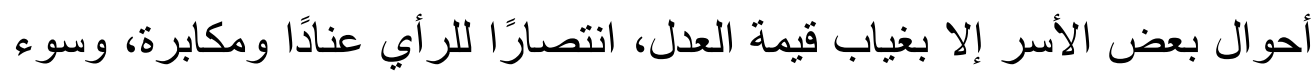

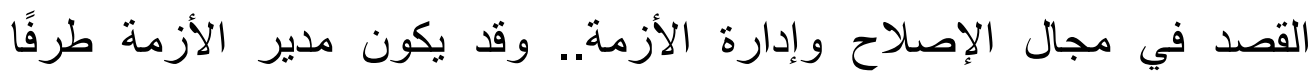

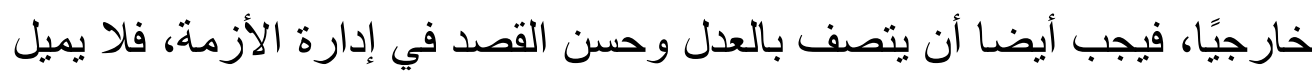

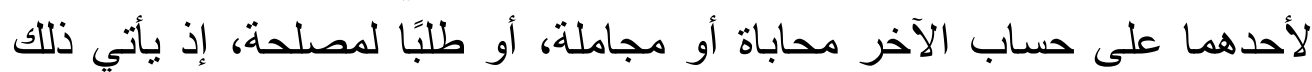

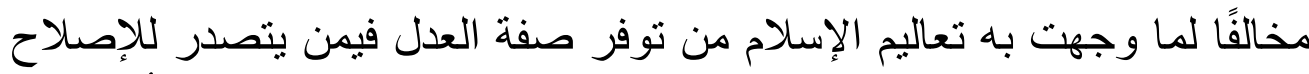

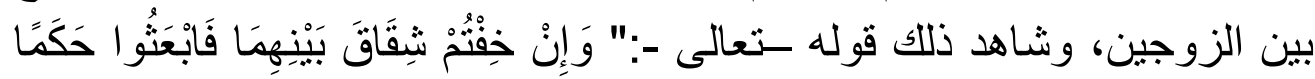

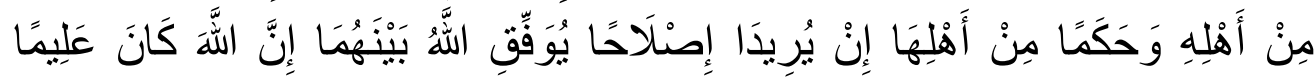

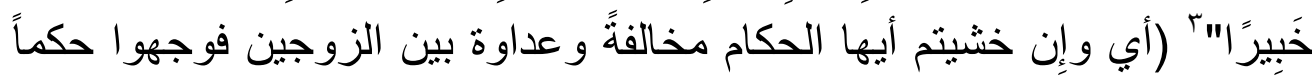

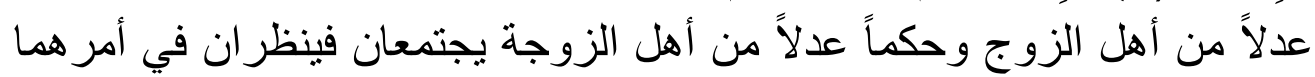

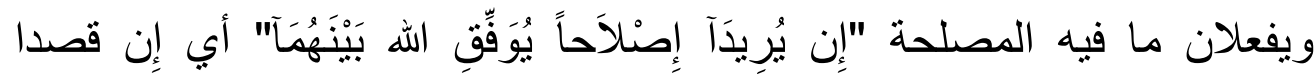

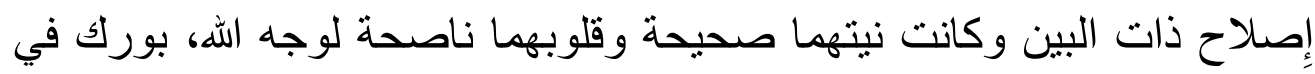

$$
\begin{aligned}
& 1 \text { - التحريم: ب. }
\end{aligned}
$$

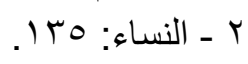

$$
\begin{aligned}
& \text { r ـ النساء: مباء: هب. }
\end{aligned}
$$


وساطتهما وأوقع الله بين الزوجين الوفاق والألفة وألقى في نفوسهما المودة

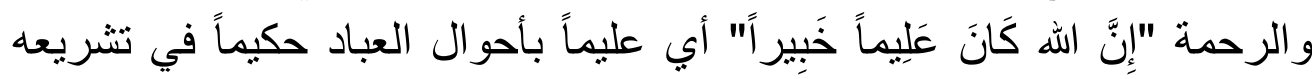
لهم) (، وبناء على هذا الفهم وجب أن يتصف مدير الأزمة بالعدل في الحكم

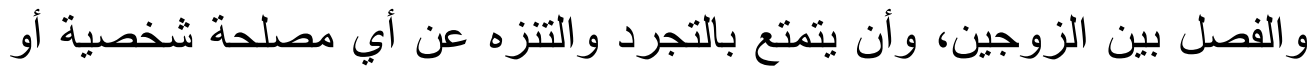
غرض دنيوي.

$\star * * * * * * * * * * * * * * * * * * * * * *$

\section{المطلب الثالث: مراحل إدارة الأزمات الأسرية}

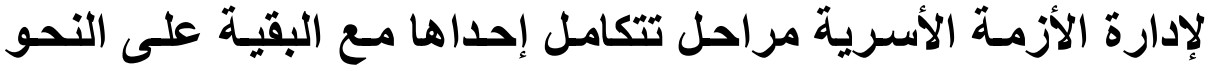

\section{المرحلة الأولى: الاكتشاف والإنذار المبكر}

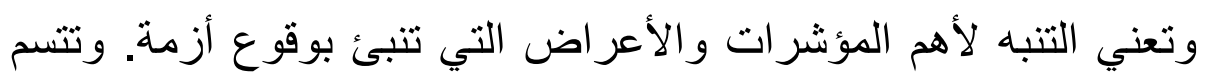
هذه المرحلة بالإعلام الفوري بخطر وشيك الوقوع عن طريق الملاحظات

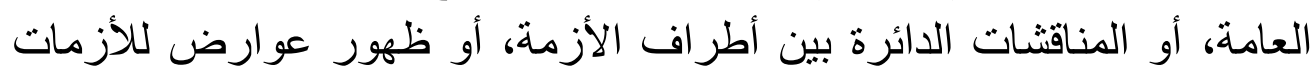

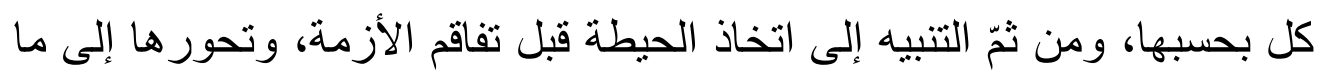

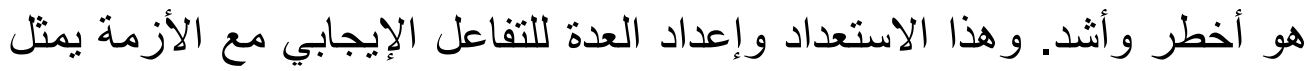

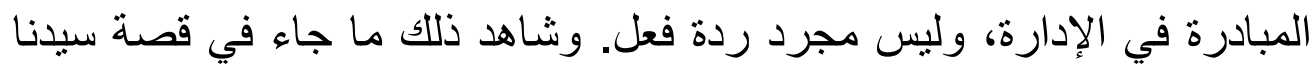

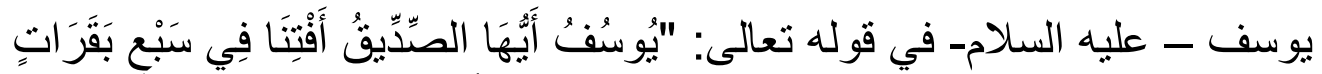

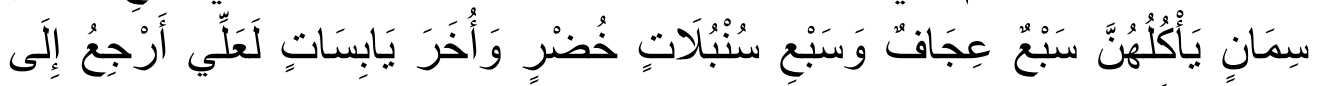

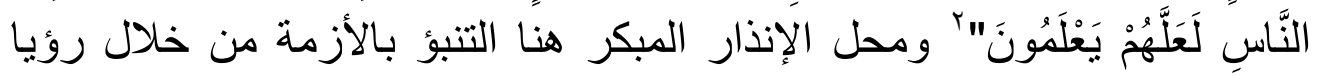

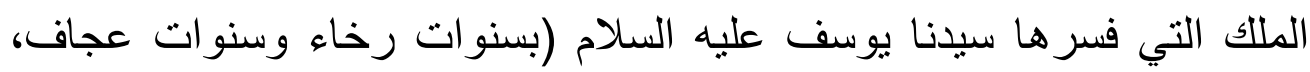

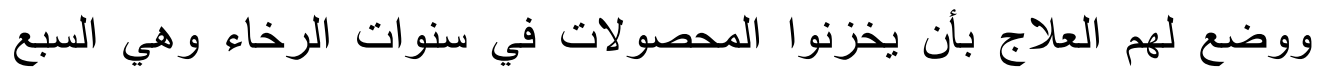

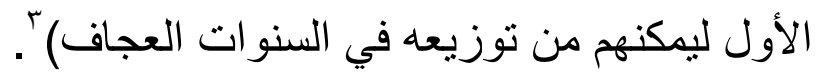
أهم مؤشر ات الأزمات داخل فئل البناء الأسري:

1 ـ ـ صفوة التفاسير، محمد علي الصابوني، دار الصابوني للطباعة و النشر و التوزيع ـ القاهرة. طا

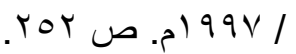

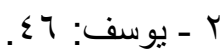

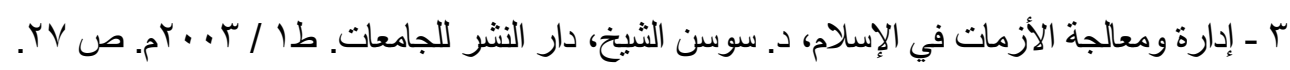




$$
-4+-
$$

تحدث بعض المؤشرات داخل الأسرة تنبئ وتتذر بحدوث أزمة تستدعي

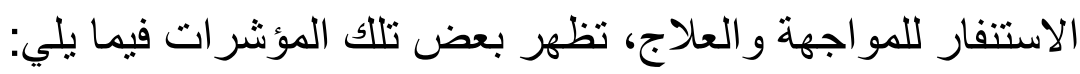
- خلل في رعاية الحقوق و الو اجبات. ـ فتتور العلاقة واضطر ابها، واحتكامها فقط إلى المطالب الجسدية.

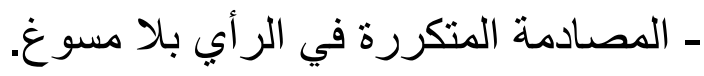
ـ كثرة المشاحنات و النزاعات، و التخاذ العزاذ العنف اللفظي أسلوبًا للحوار.

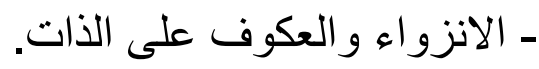
ـ اضمحلال القيم الإسلامية في المحيط الأسريّ.

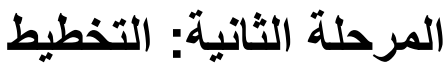

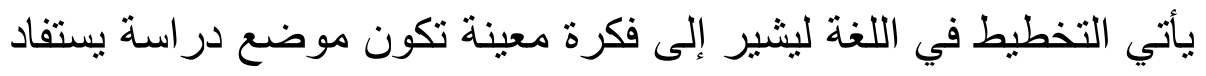

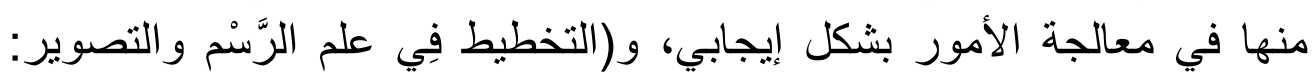

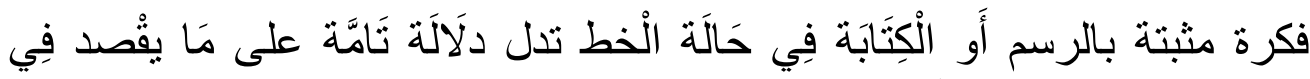

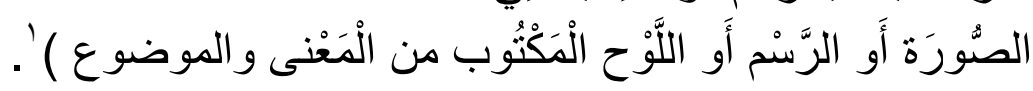

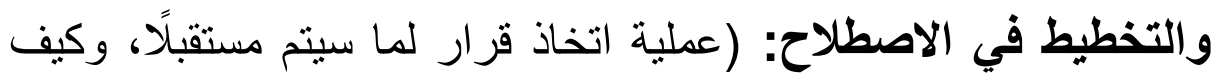

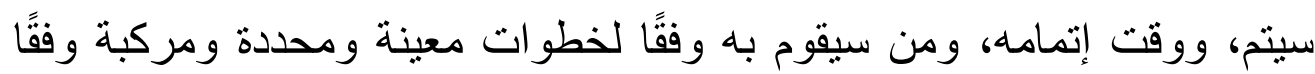

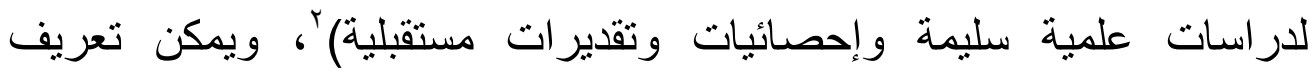

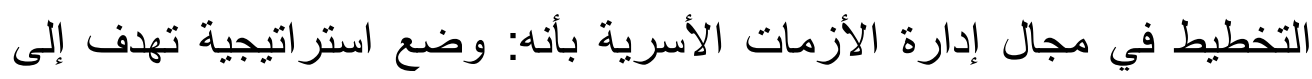

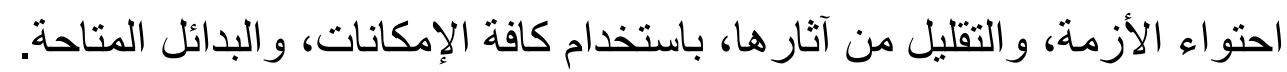

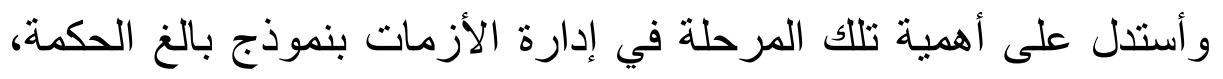

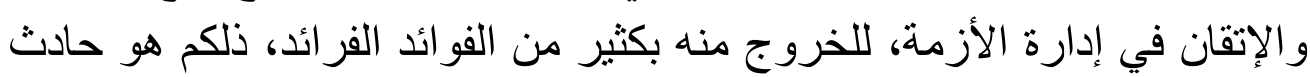

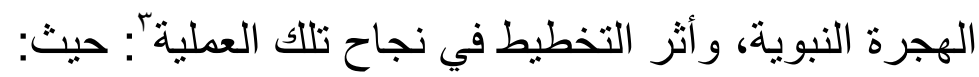

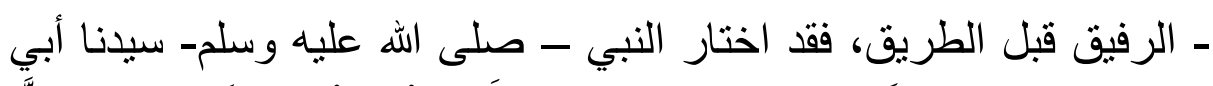

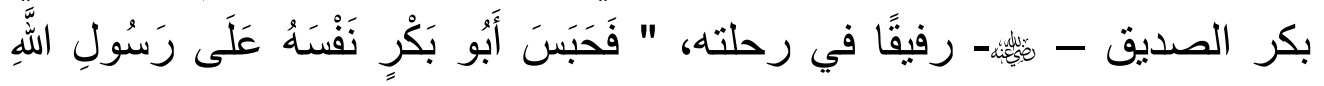

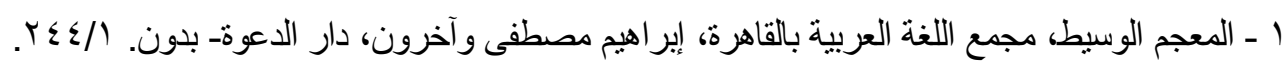

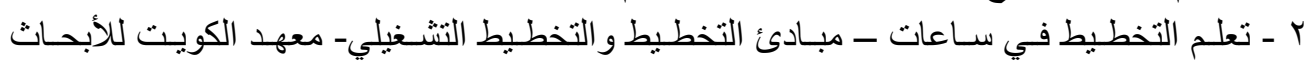

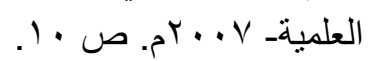

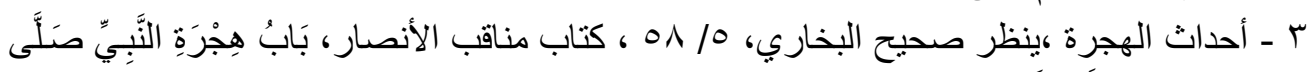

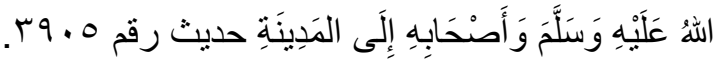




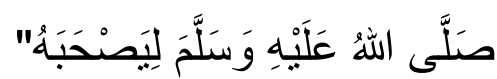

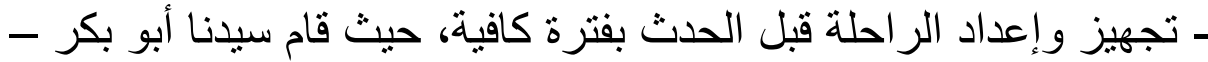

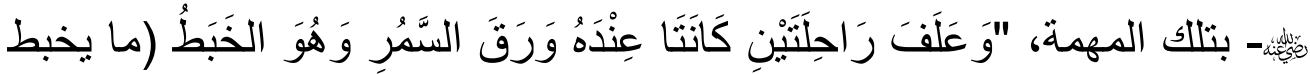

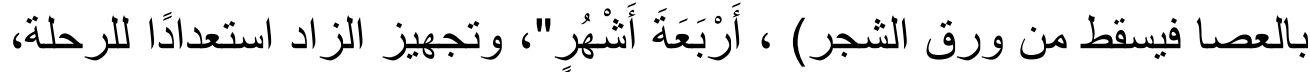

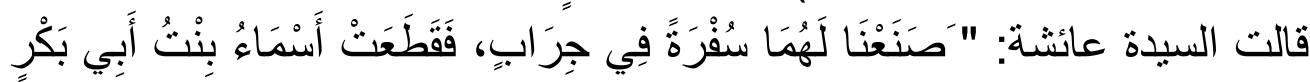

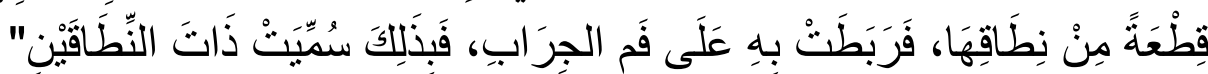
- التمويه: يظهر في تكليف سيدنا علي بن أبي الطالب بالنوم في فراش

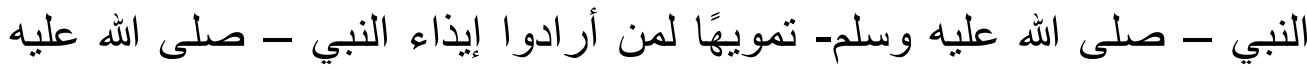

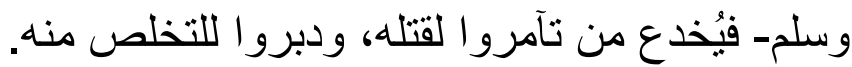

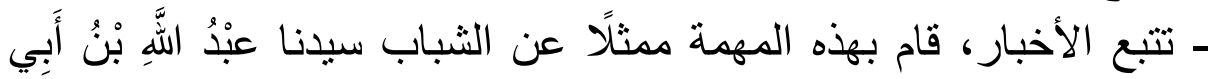

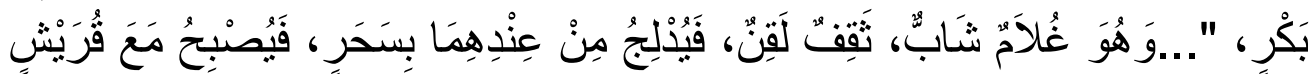

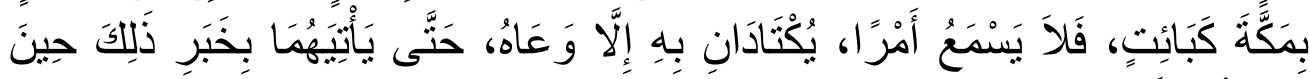

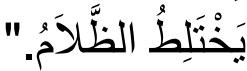

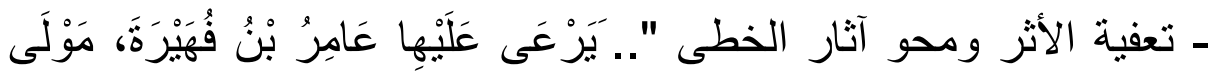

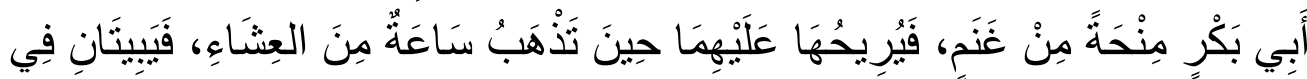

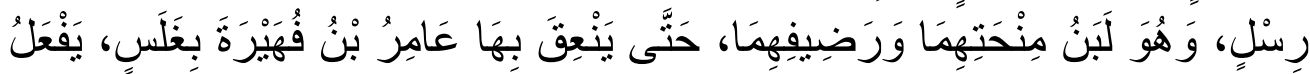

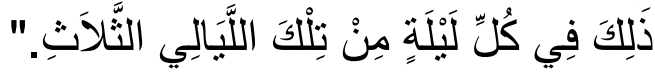

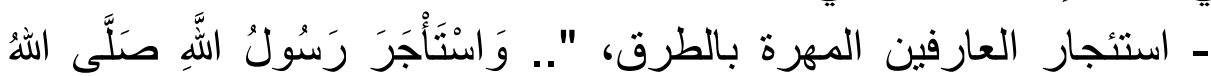

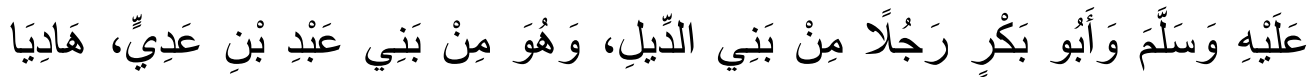

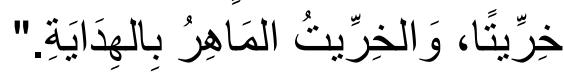

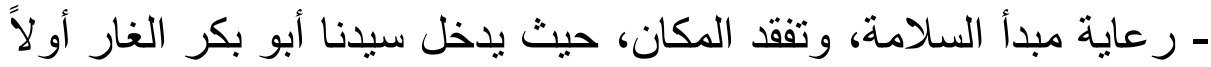
يتفقد ما بداخله من سباع وهو ام مؤذية فيكون هو فداء لصاحبه ـ ـ صلي الله عليه وسلم - وكان في ذلك الغار حجر فيضع عليه عقبه حتى لا يخرج منه ما يؤذي موني صاحبه - صلو ات الله وسلامه عليه.

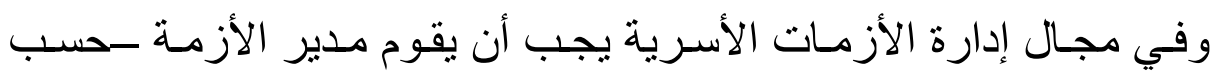

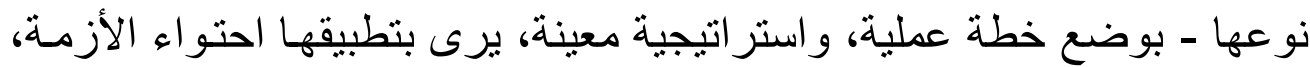
و التقليل من آثار ها. المرحلة الثالثة: احتواء الأزمة 
-TTr

وتهدف هذه المرحلة إلى تتفيذ ما خطط له من أجل محاصرة الأزمة،

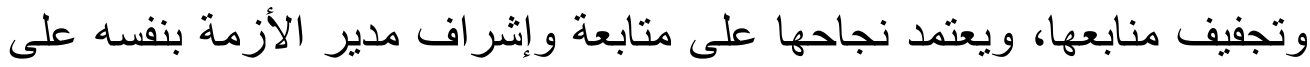

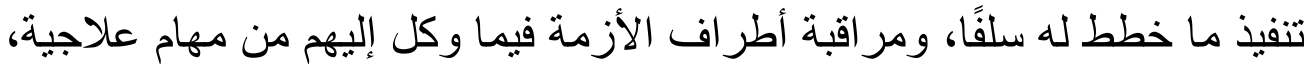

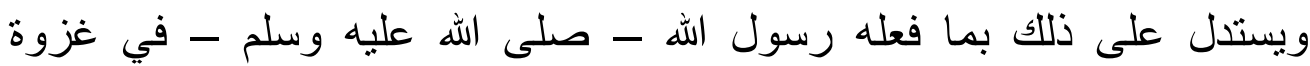

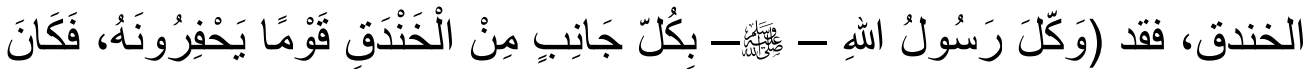

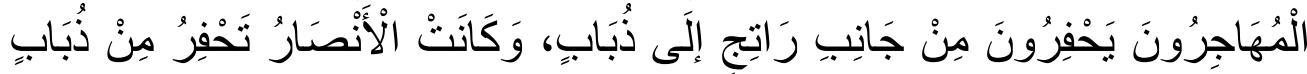

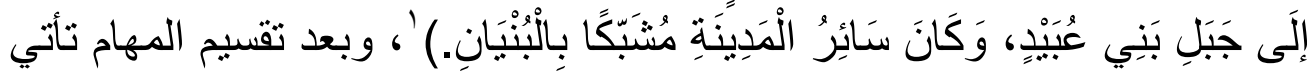

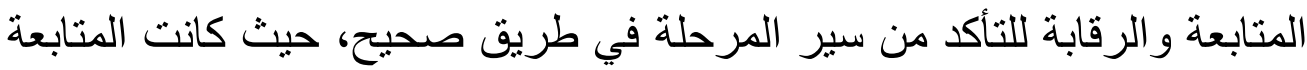

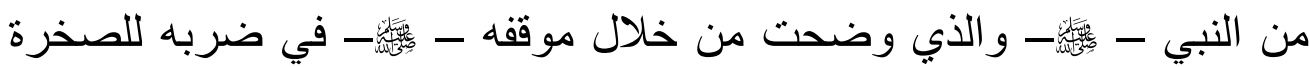

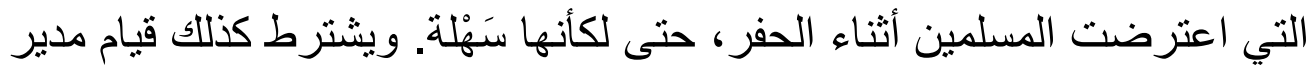

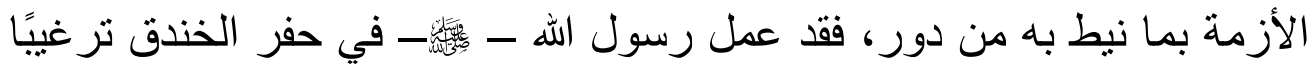

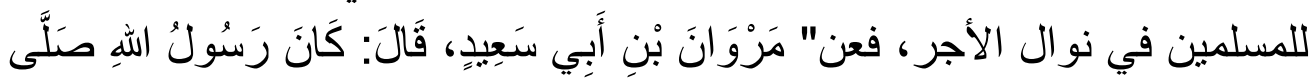

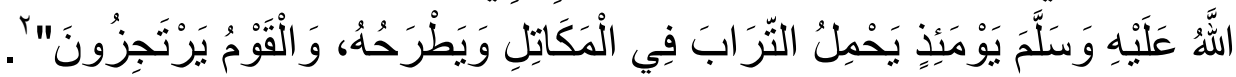
المرحلة الرابعة: استعادة التوازن

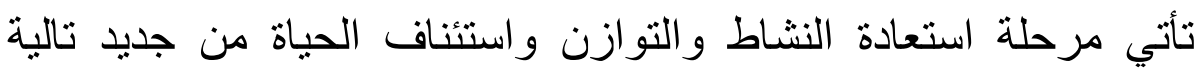
لمرحلة احتواء الأزمة، فيها يستجمع أطر اف الأزمة قواهئ اهم من جديد، وخير مثال

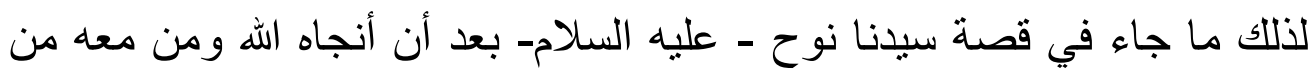

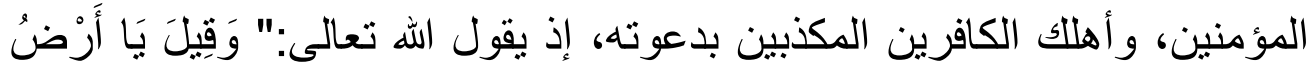

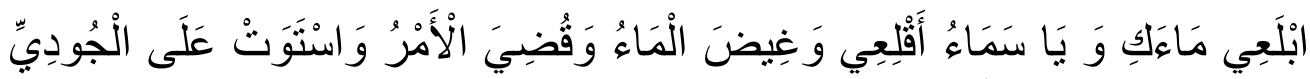

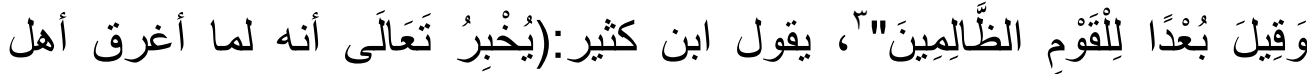

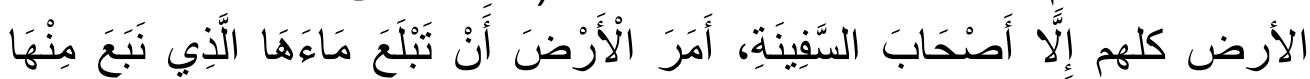

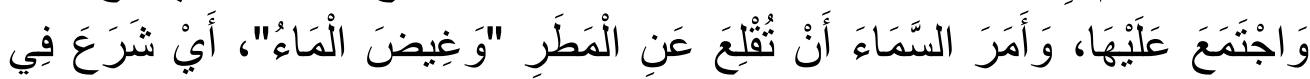

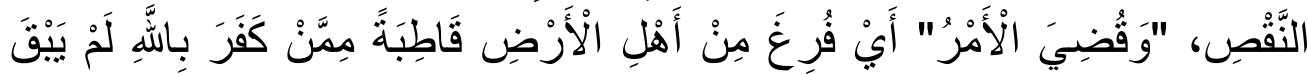

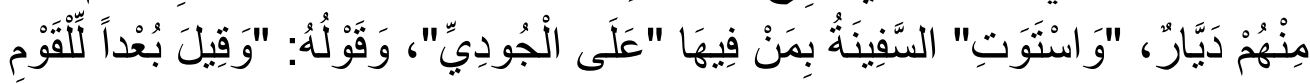

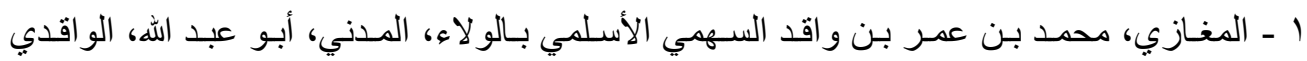

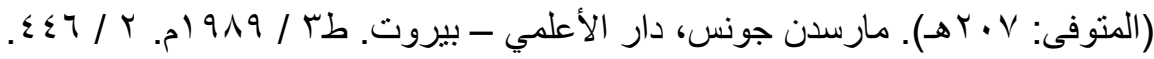

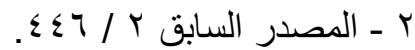




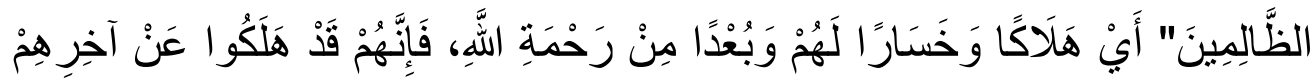

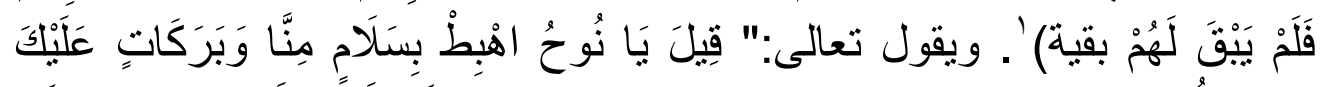

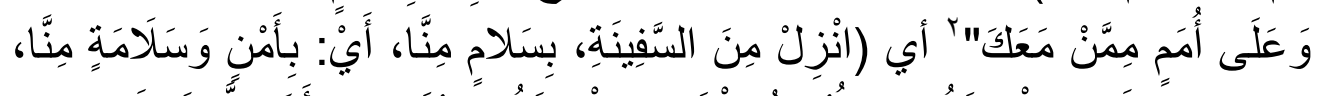

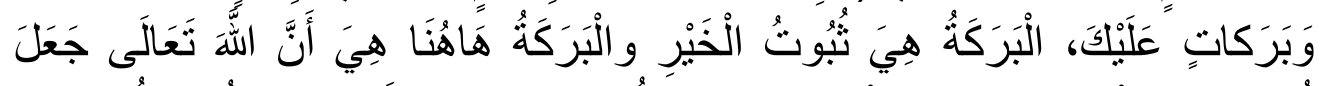

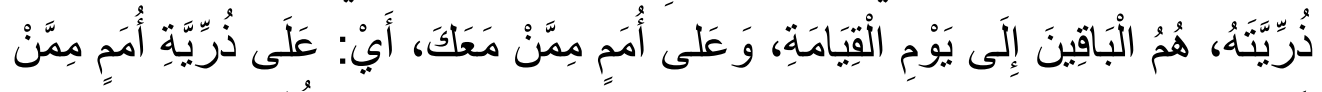

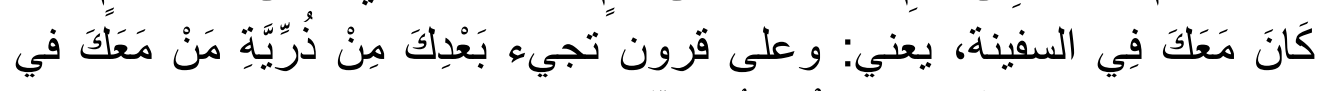

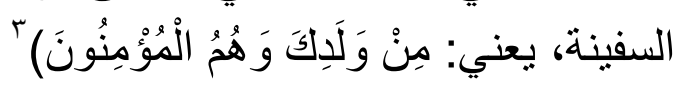

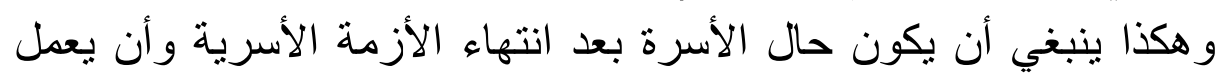

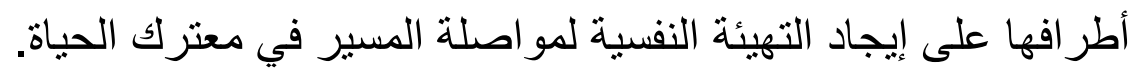

\section{المرحلة الخامسة: الاستفادة والتعلم}

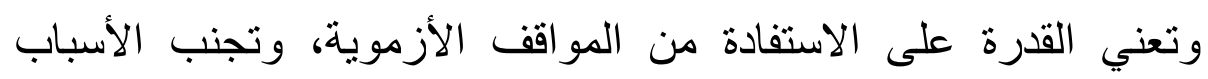

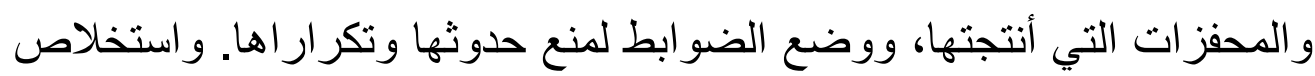

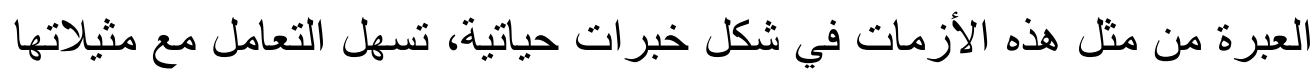

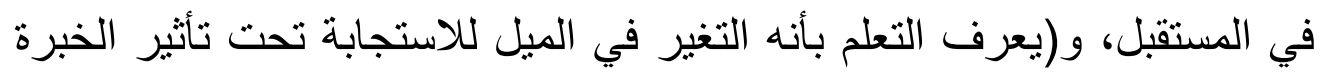

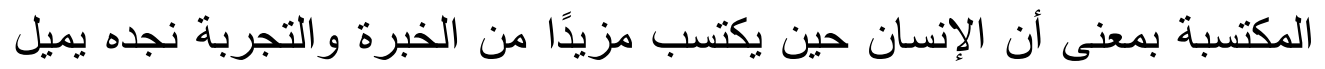

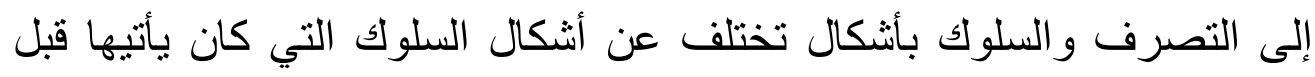

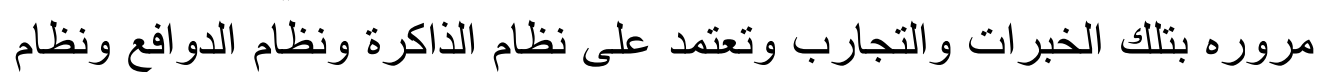

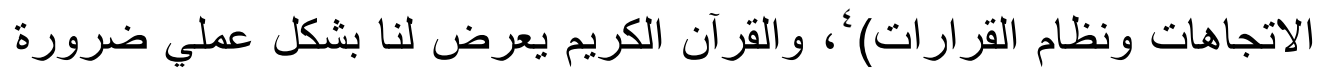

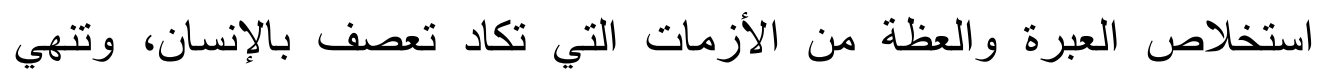

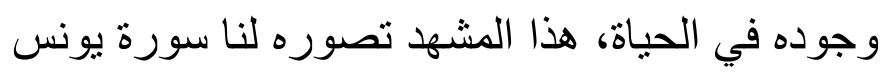

I ـ مختصر تفسير ابن كثير ، (اختصار وتحقيق) محمد علي الصابوني، دار القرآن الكريم، بيروت

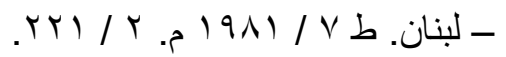

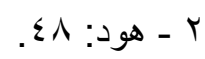

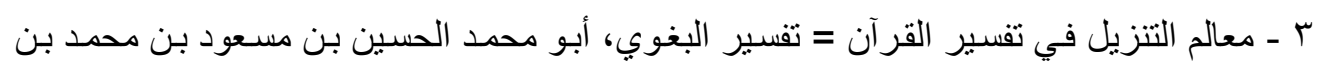

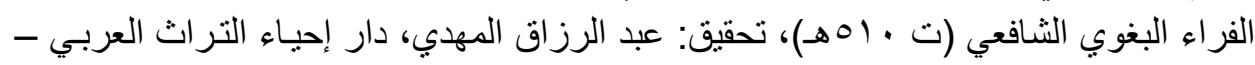

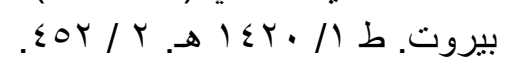

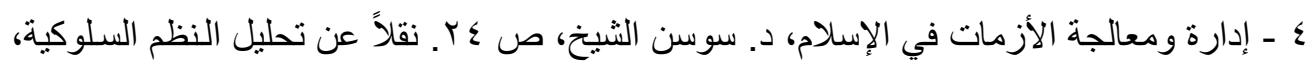

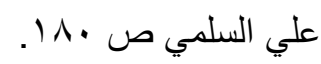




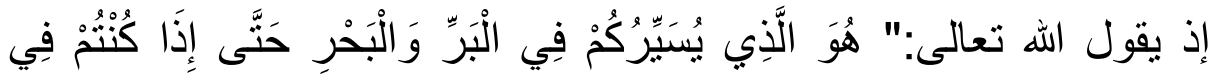

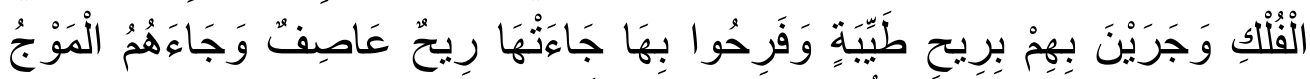

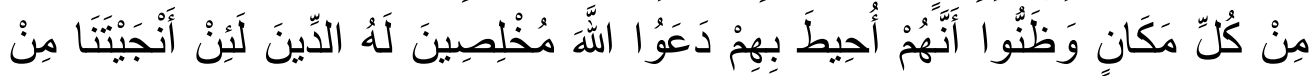

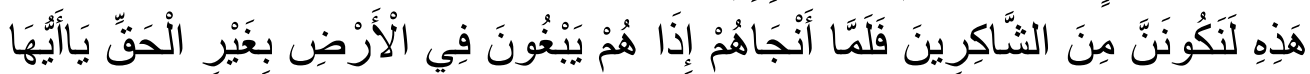

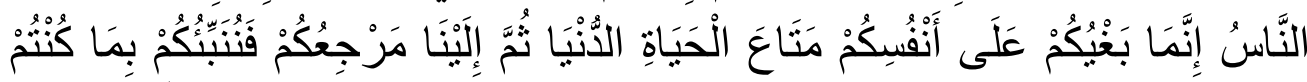

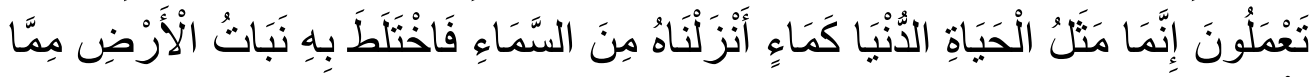

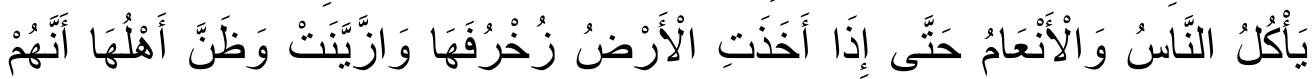

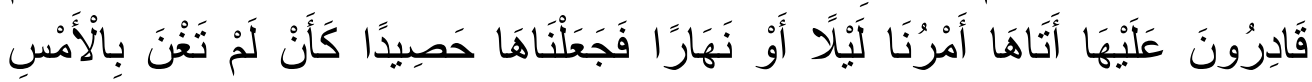

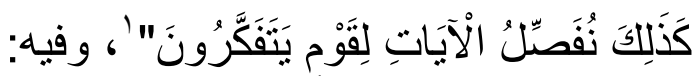

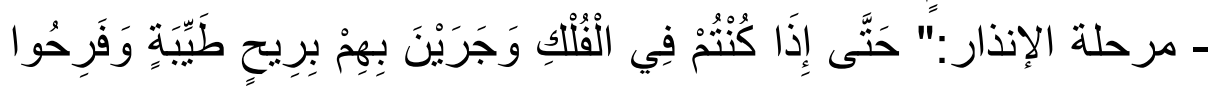

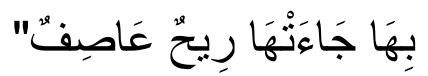

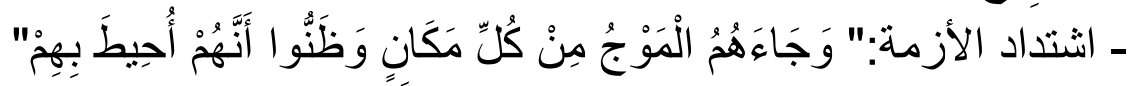

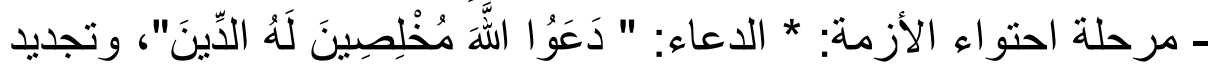

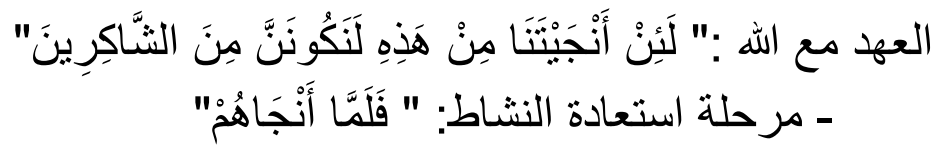

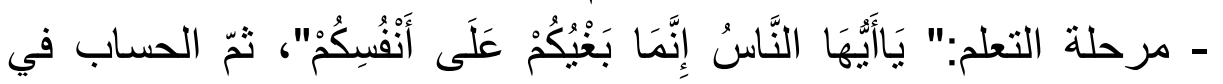

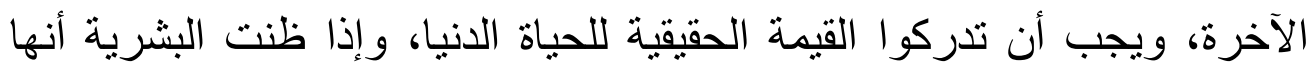

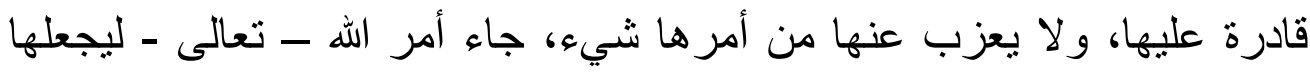

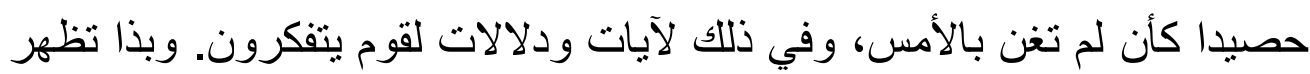

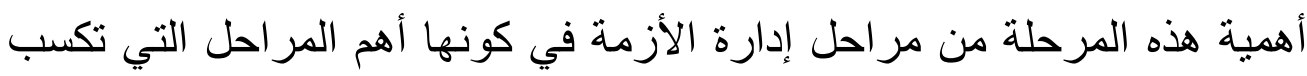

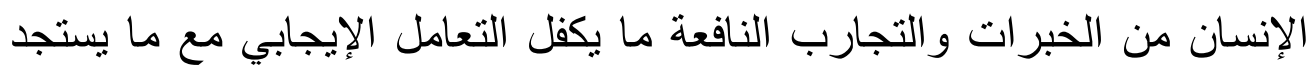
على الصعيد الأسريّ من مشكلات وأزمات. 


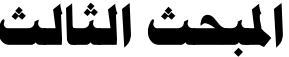

\section{نماذج تطبيقية}

فيما يلي أعرض بعض النماذج التطبيقية في إدارة الأزمات التي

تتعرض لها الأسرة المسلمة، على النحو الآتي:

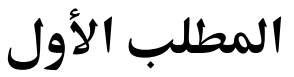

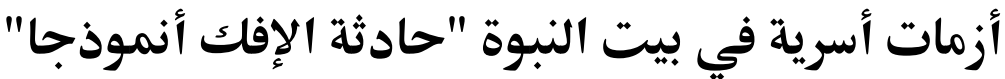

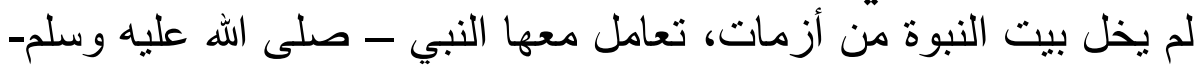

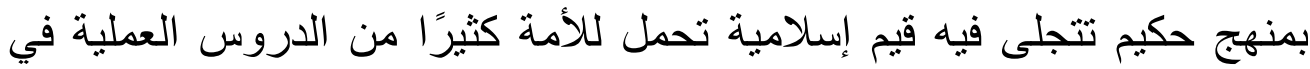
إدارة شؤون الأسرة، بما بحفظ للأفراد حقوقهم، وتحقق للادئ للأسرة أمنها

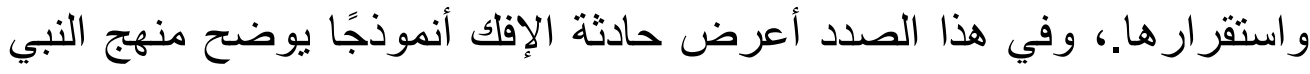

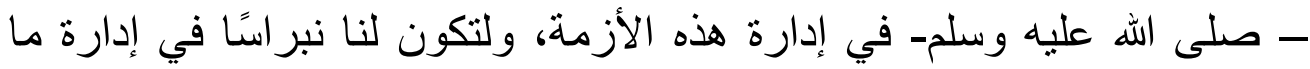

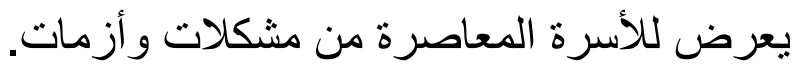

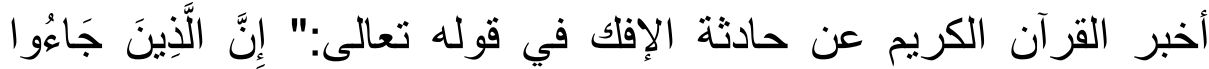

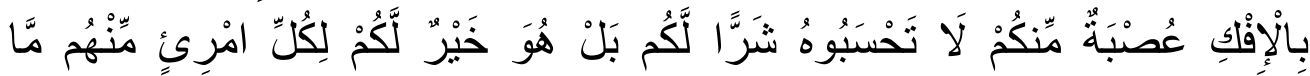

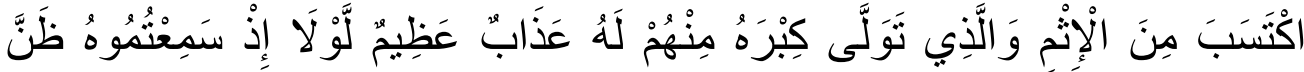

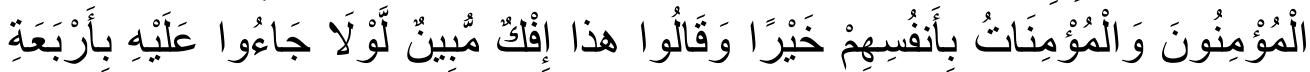

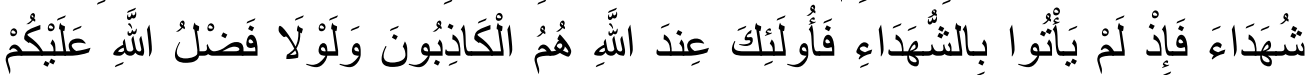

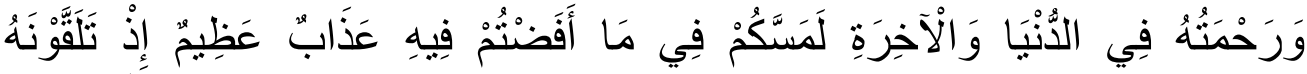

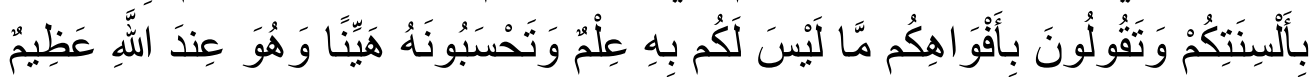

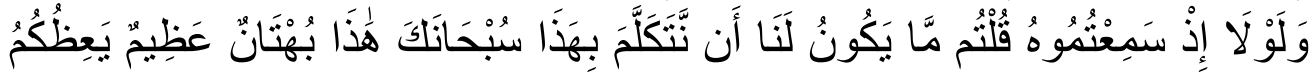

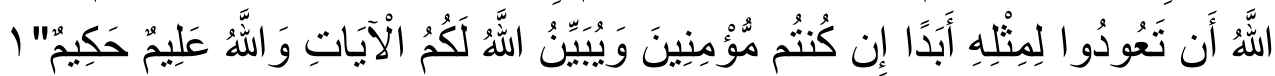

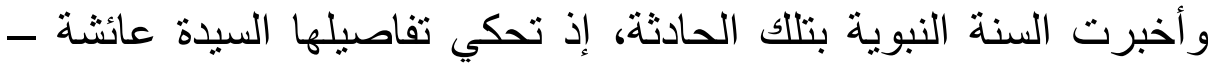

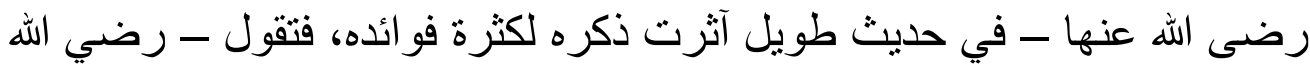

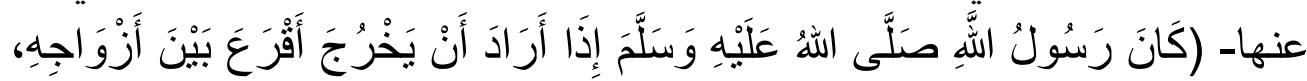

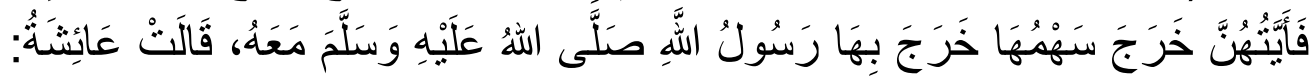




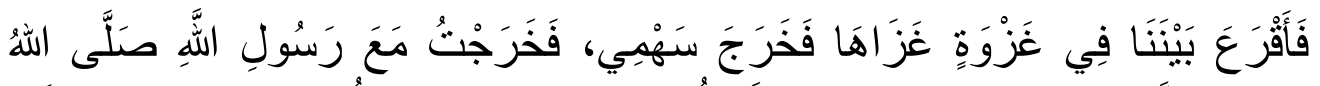

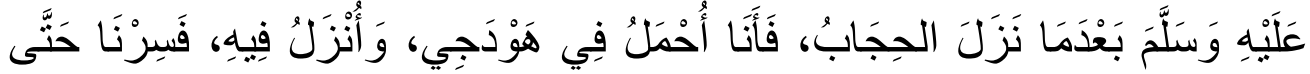

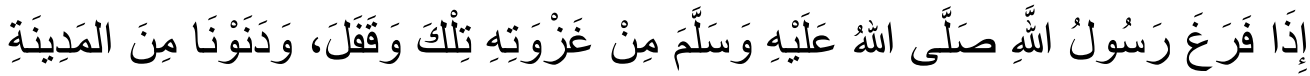

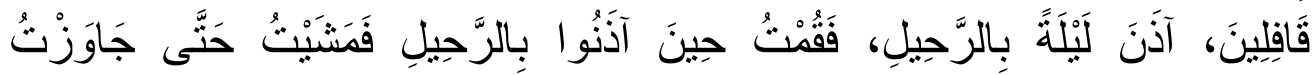

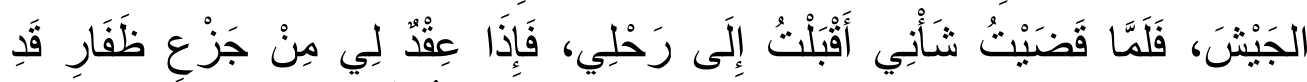

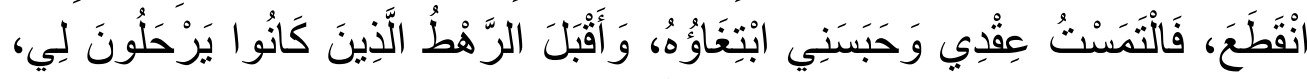

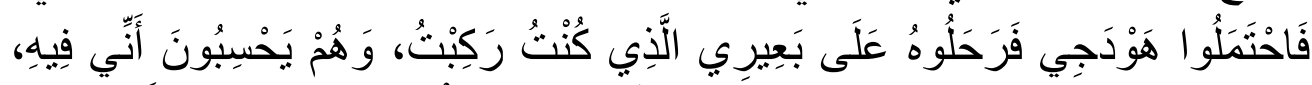

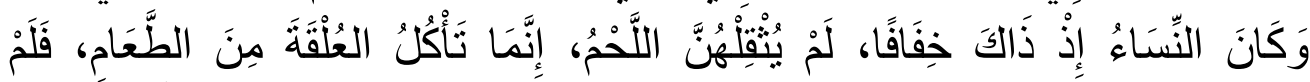

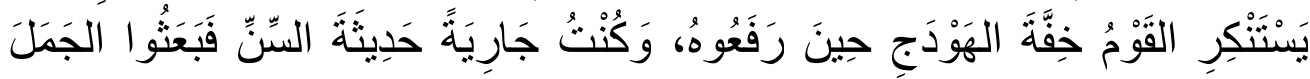

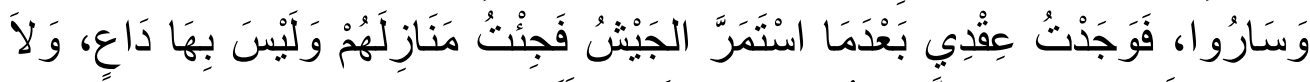

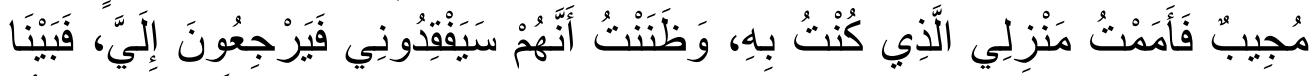

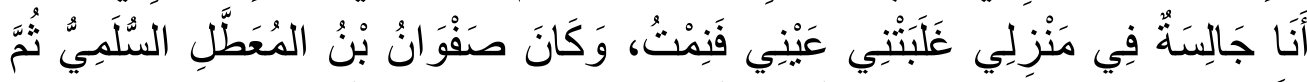

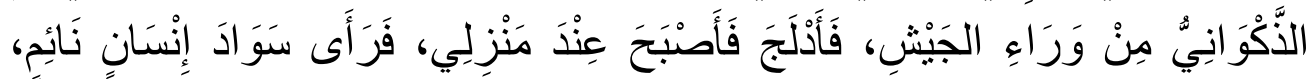

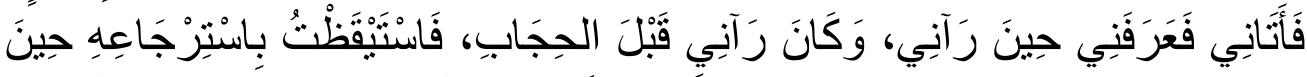

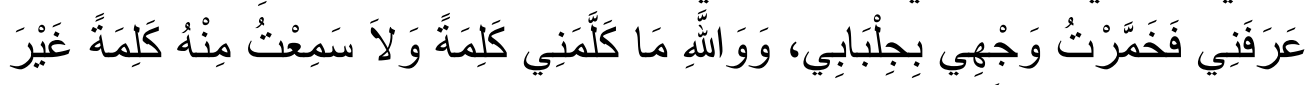

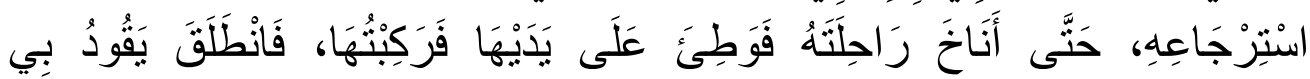

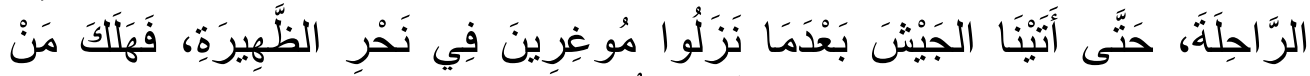

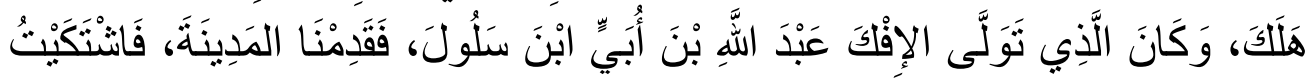

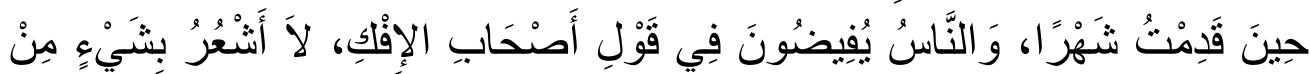

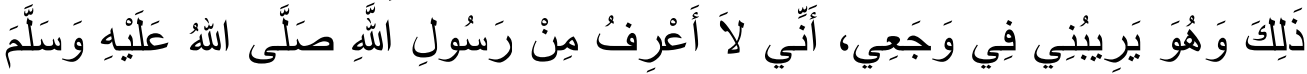

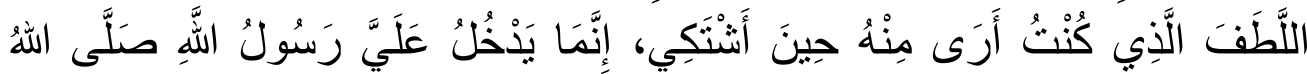

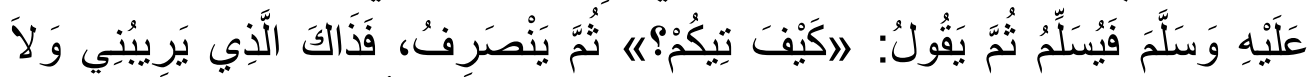

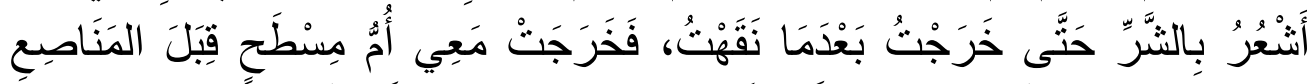

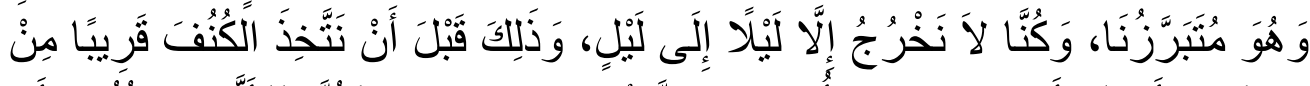

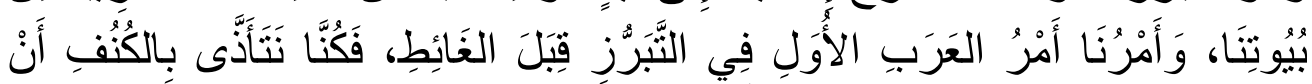

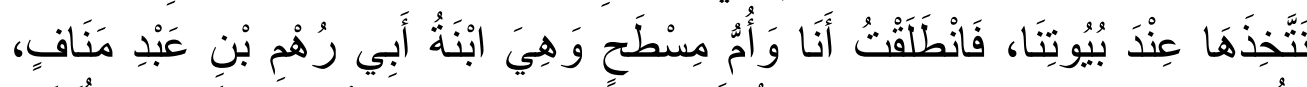

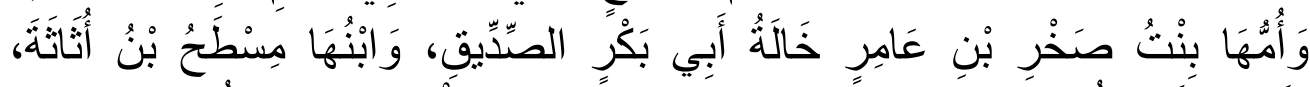

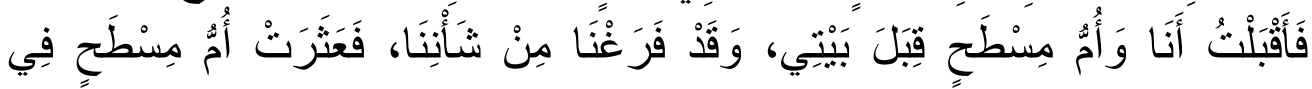




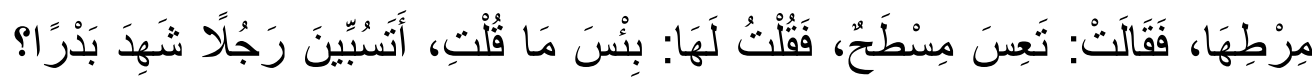

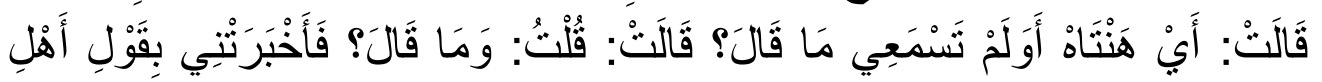

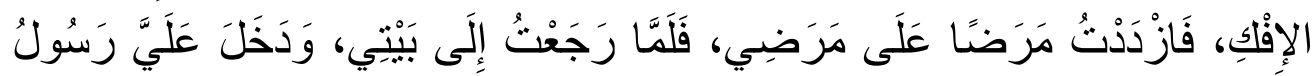

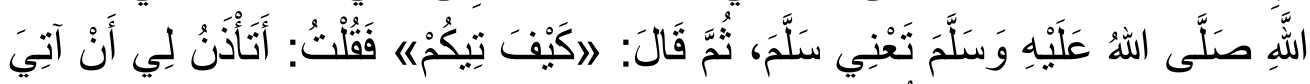

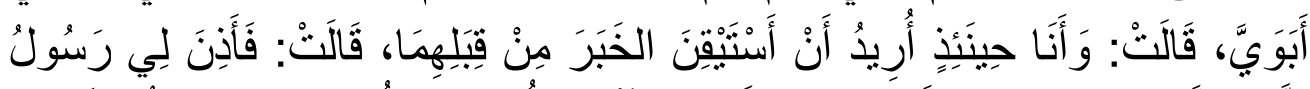

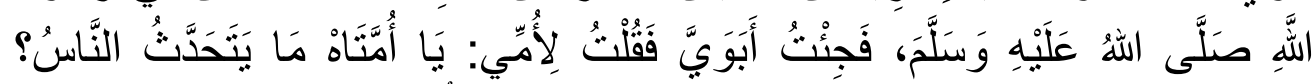

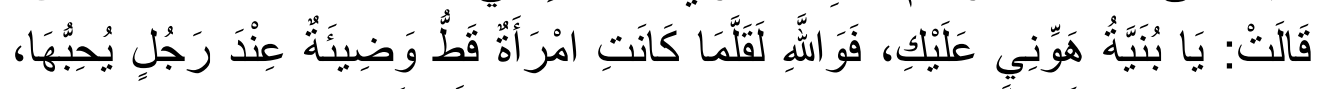

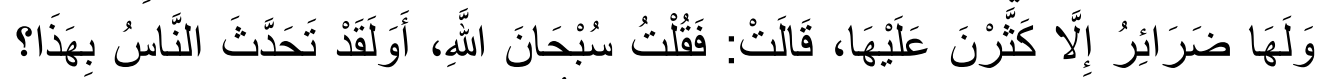

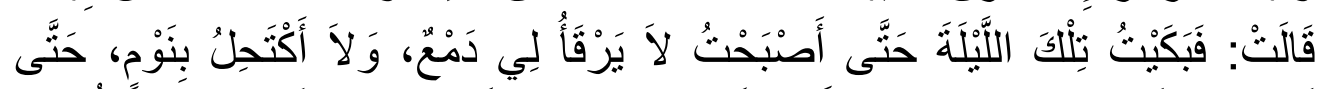

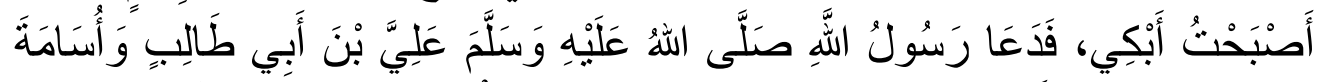

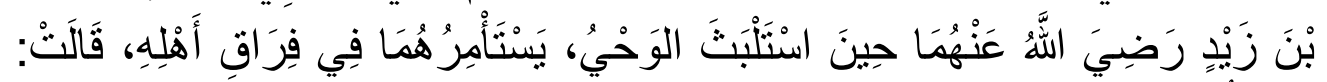

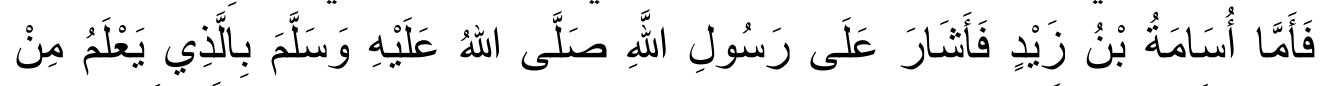

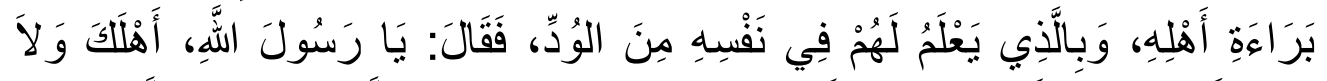

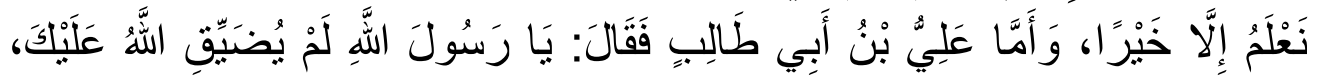

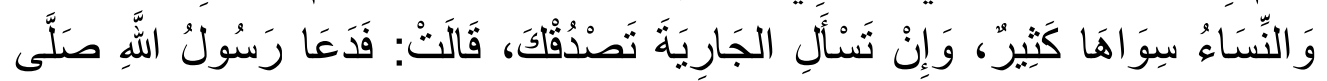

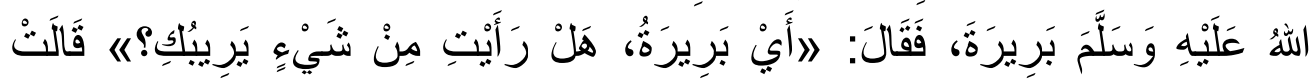

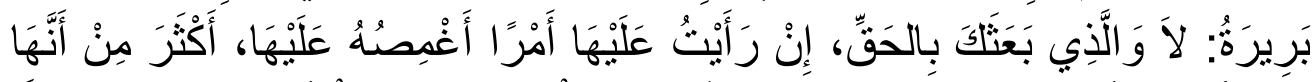

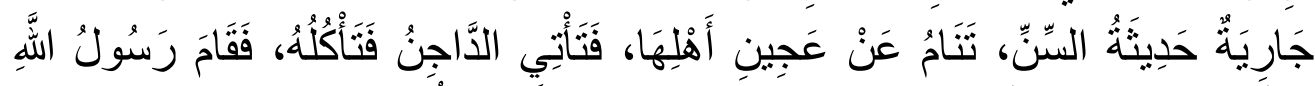

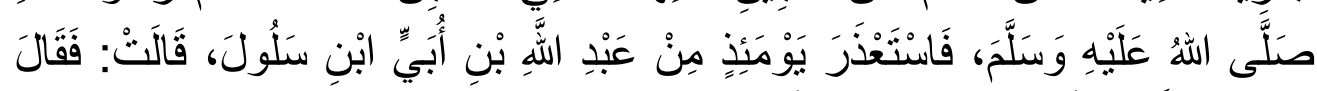

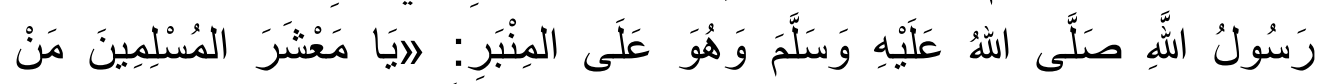

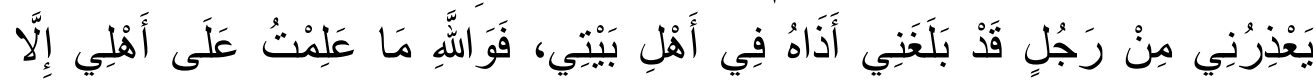

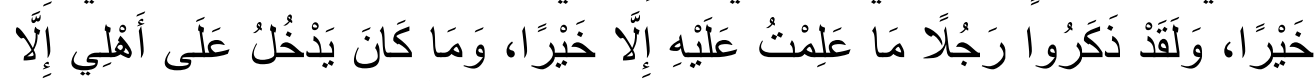

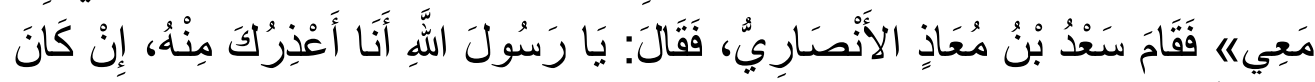

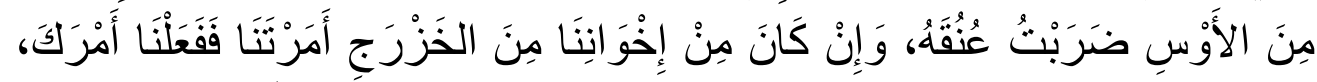

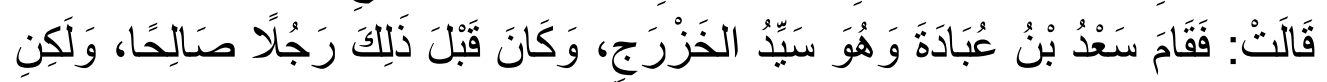

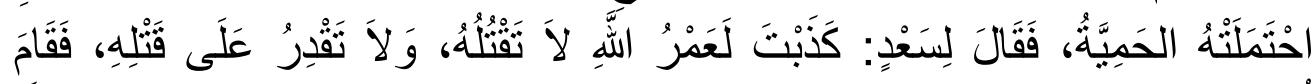

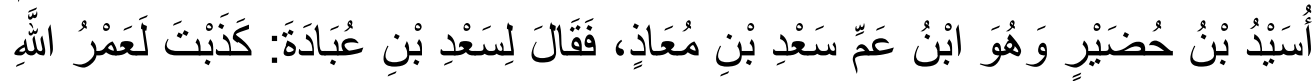

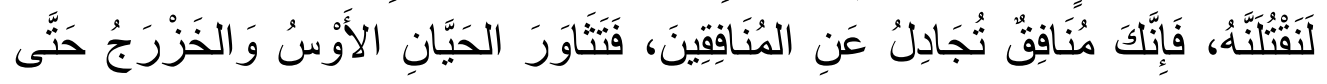


-7T人_

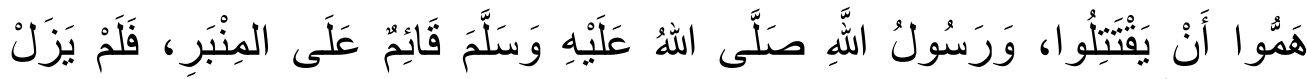

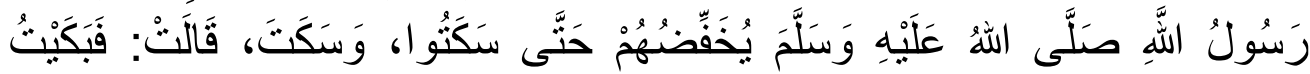

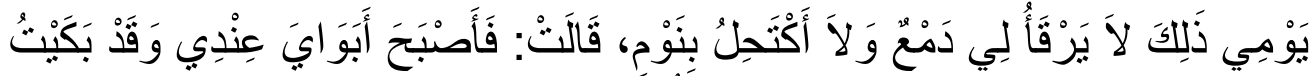

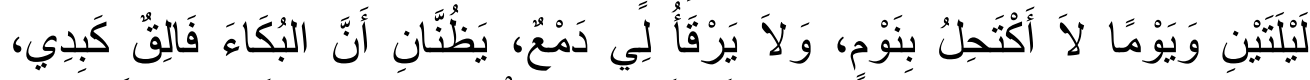

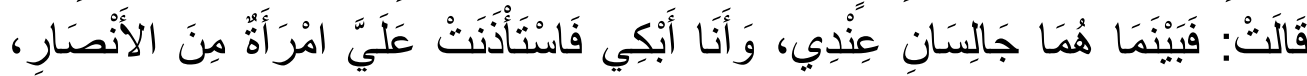

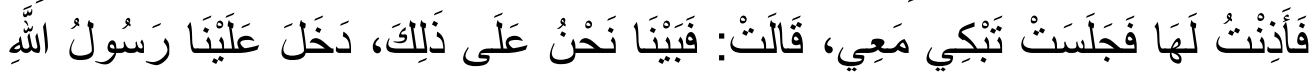

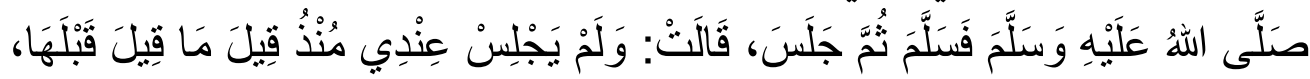

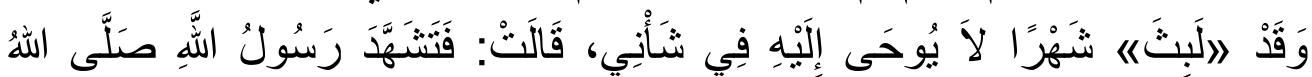

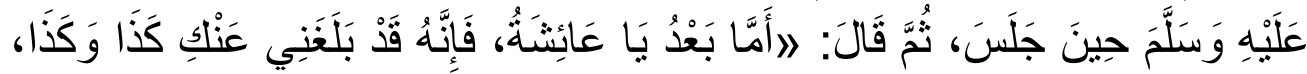

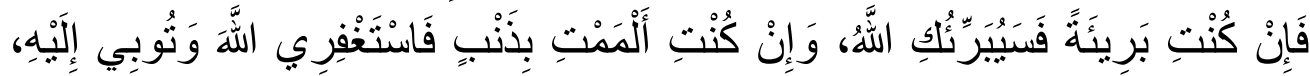

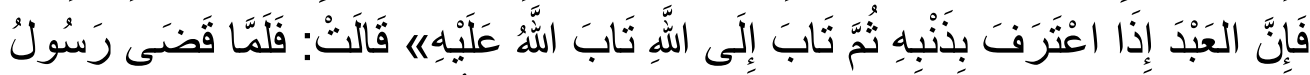

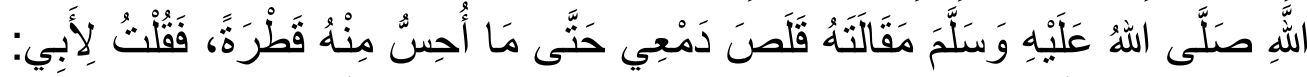

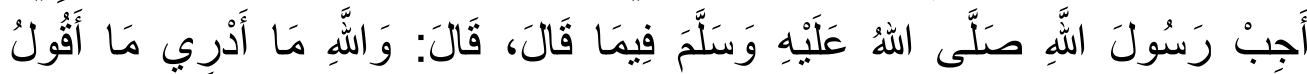

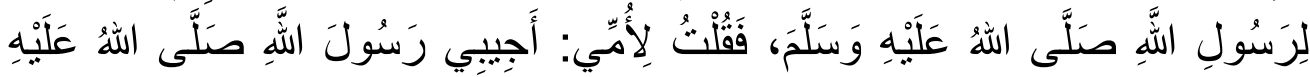

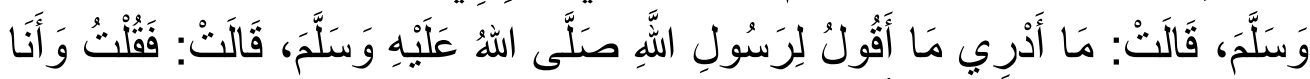

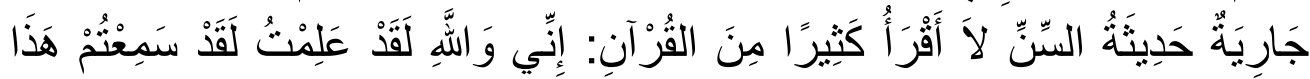

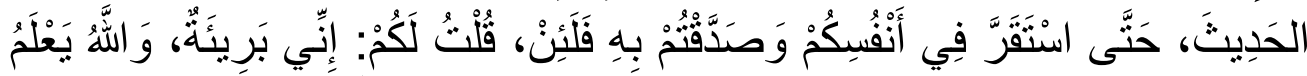

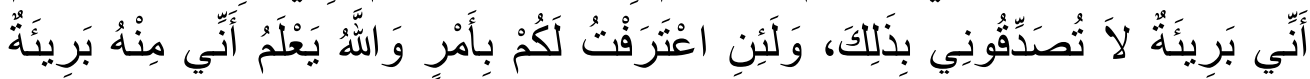

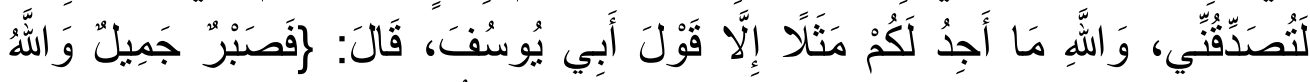

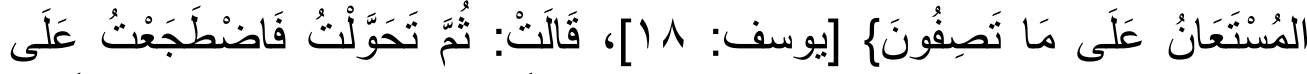

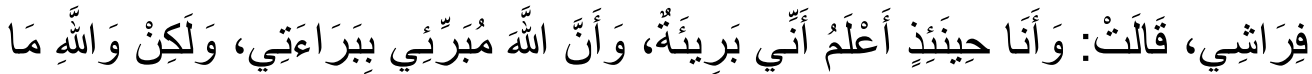

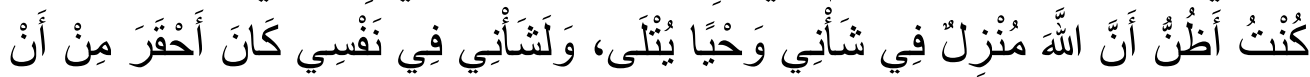

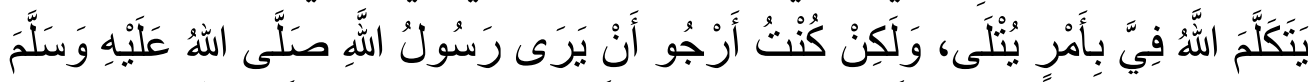

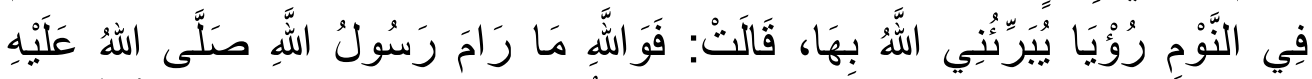

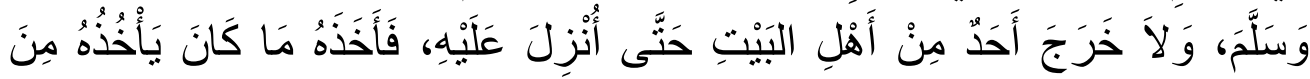

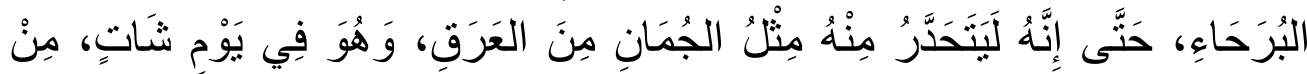

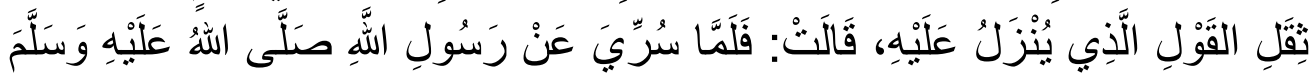

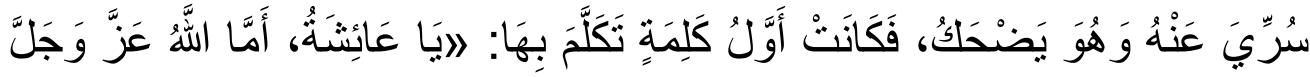




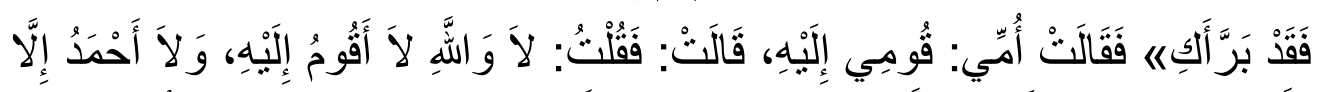

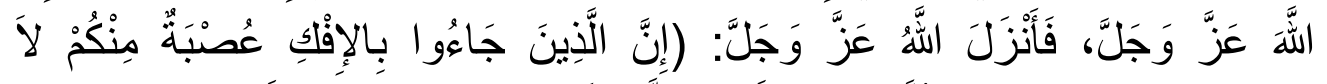

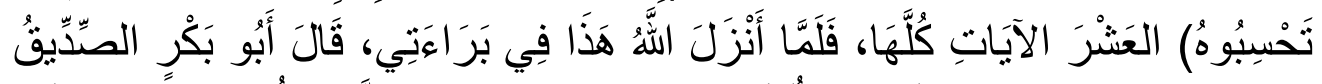

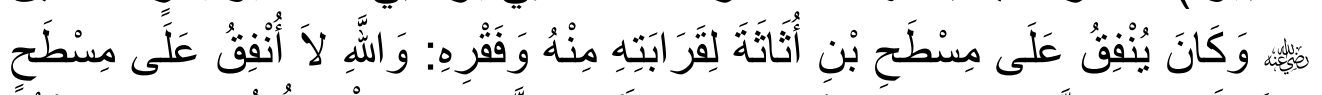

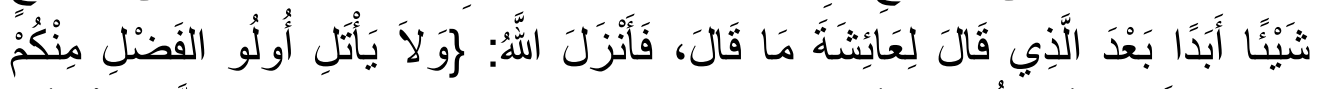

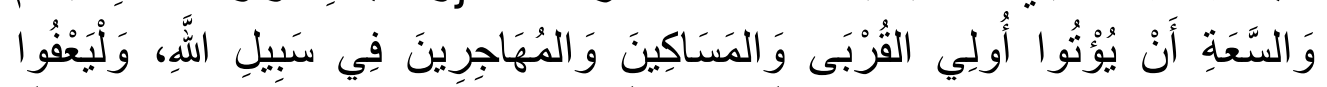

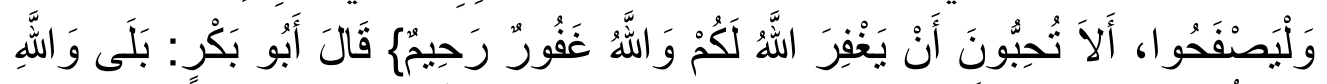

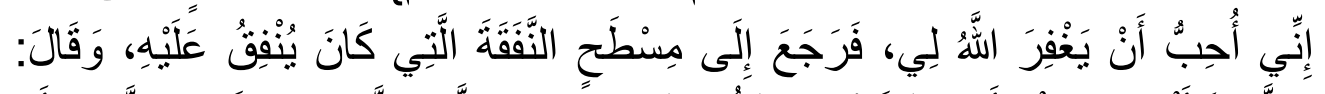

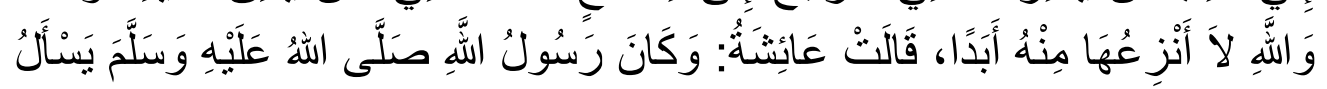

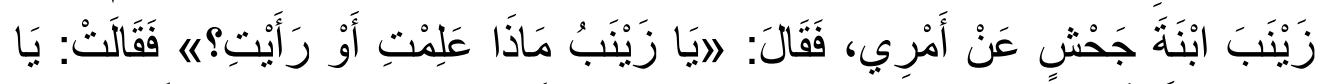

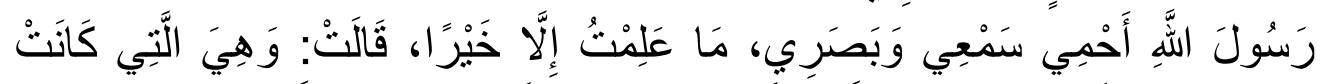

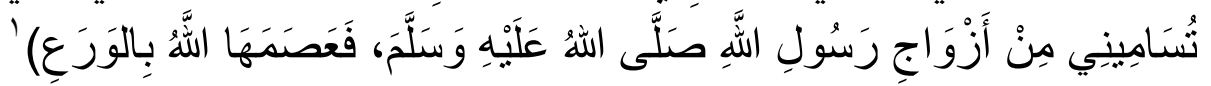

\section{خطورة الأزمة: مانو}

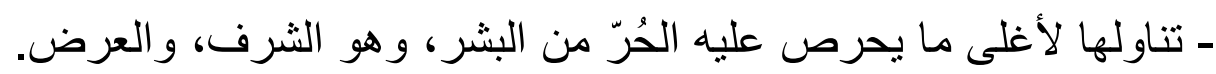

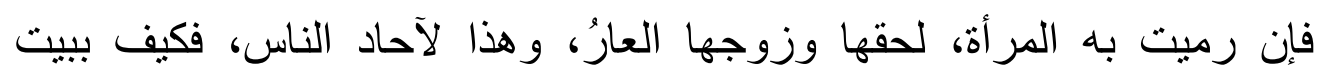

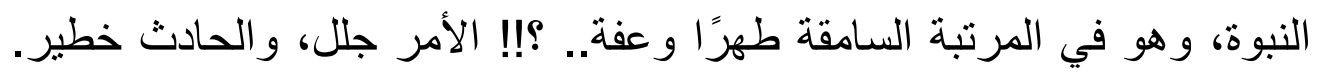

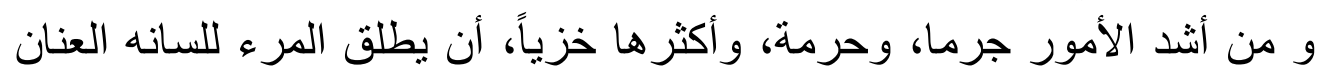

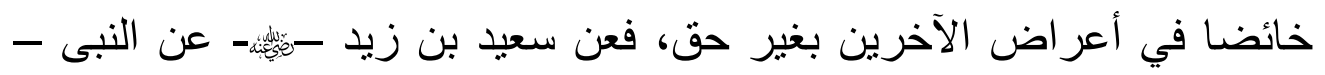

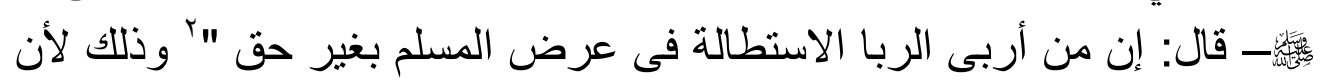

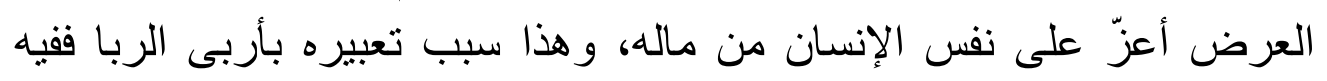

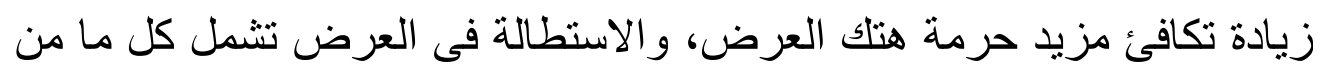

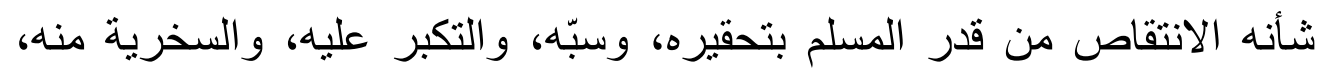

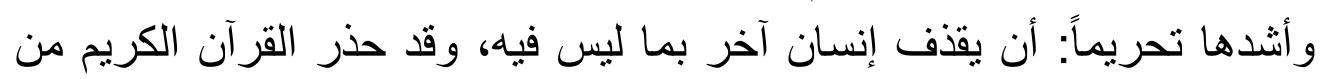

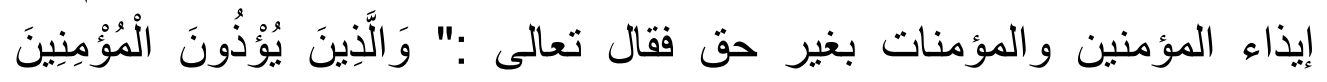

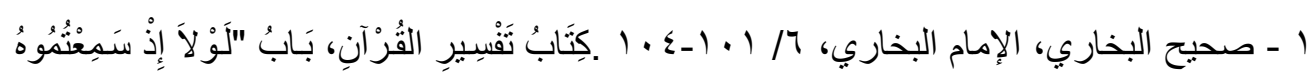

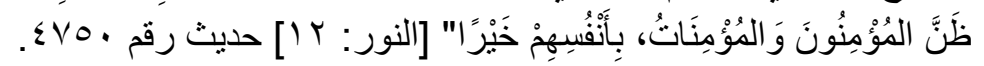

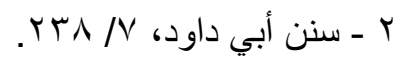




\section{$-7 \leqslant$.}

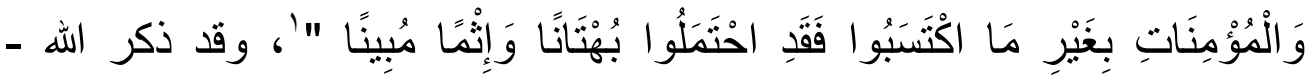

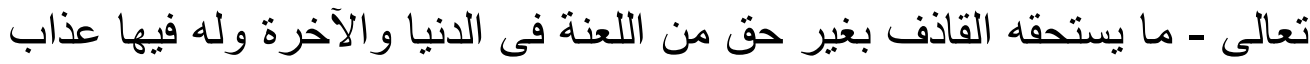

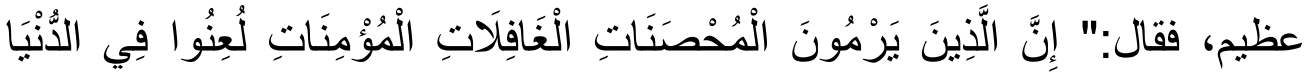

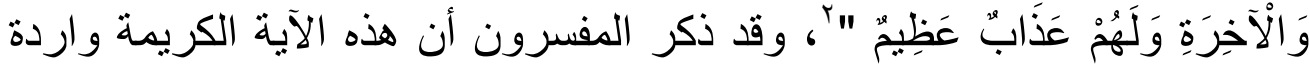
فى شأن أم المؤمنين عائشة -رضى الله عنها- بيد أن الحكم بها عام يدخل فيه كل

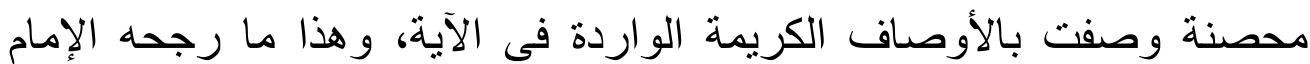

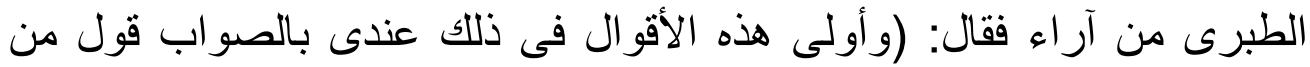

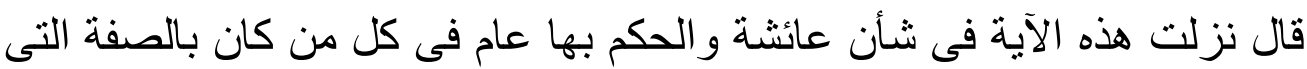

$$
\text { وصفه الله بها فيها،)". }
$$

ـ أصابت الأزمة أطهر بيت في الوجود - بيت النبوة -ـ فيه خير خلق الله

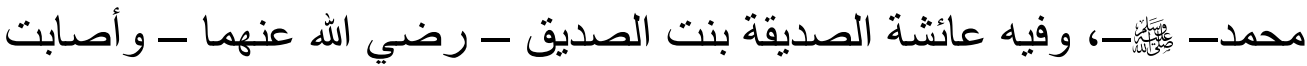

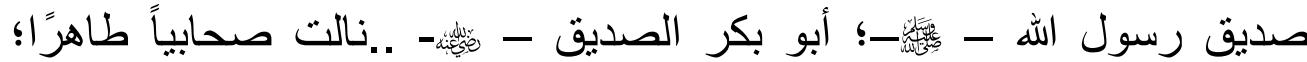
صفوان بن المعطل ..آذت المؤمنين في مشاعرهم، فلم يكن حدثًا ليمر هكذا لئرا

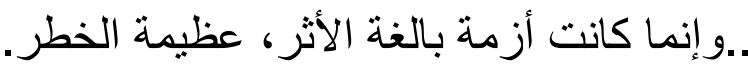

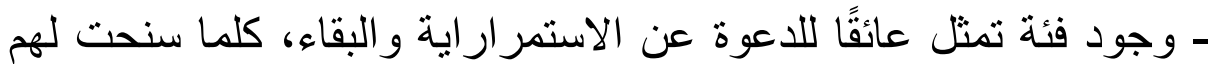

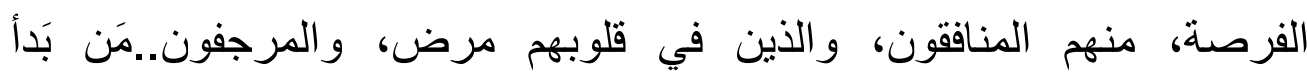

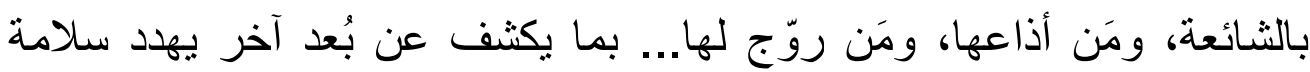
الأسرة و المجتمعات بل الأوطان.

\section{مرحلة الإنذار والاكتشاف المبكر للأزمة:}

- رجوع السيدة عائشة تتفقد عقدها، ولم يعلم بذللك أحد.

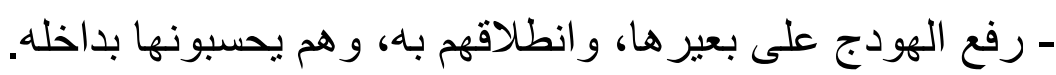
ـ انطلاق سيدنا صفوان يقود الر احلة بالسيدة عائشة، حتى أتوا الجيش.

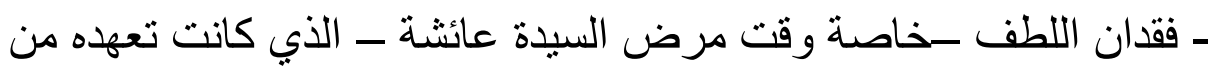

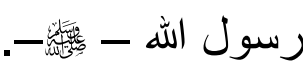

$$
\begin{aligned}
& \text { 1 ـ الأحزاب: } \\
& \text { r - النور:بr - الاحزب }
\end{aligned}
$$

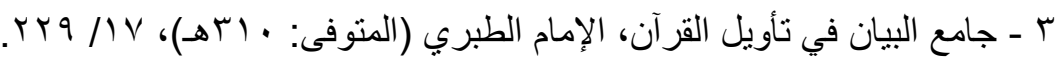




\section{مرحلة التخطيط:}

ـ التأنّي الحكيم حيال التخطيط لإدارة الأزمة.

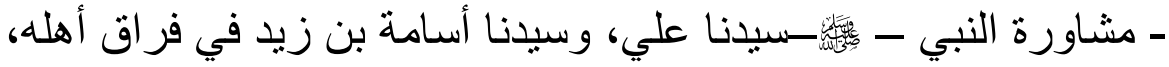

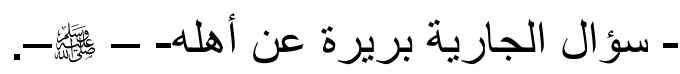

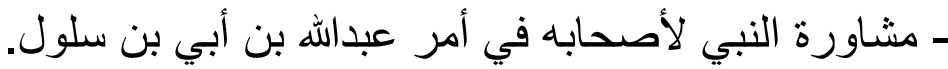

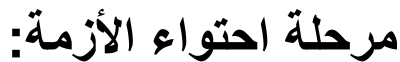

- عدم تدخل أطر اف خارجية في إدارة الأزمة.

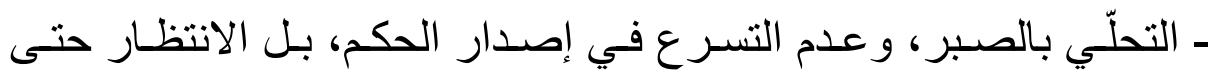
نزول الوحي. ـ اختيار أسلوب المواجهة في الوقت المناسب، إذ دخل النبي -

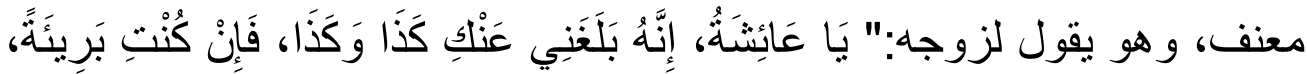

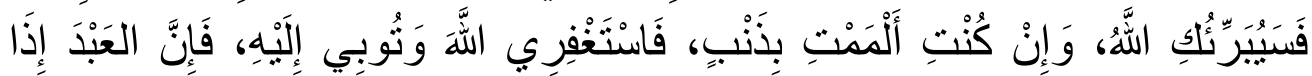

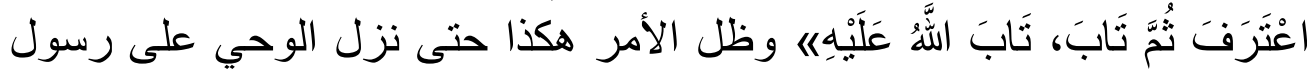

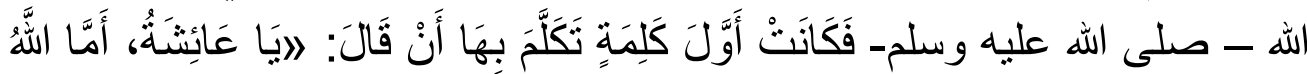

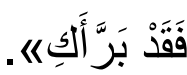

\section{مرحلة استعادة التوازن:}

فرحة تعمّ بيت النبوة بإعلان البراعة من فوق سبع سموات، تحمد السيدة عائشة ربها أن منّ عليها وشرفها بنزول آيات كريمات تنلى إلى يوم القيامة،

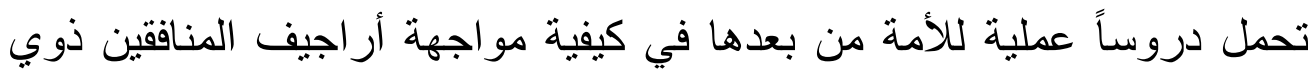

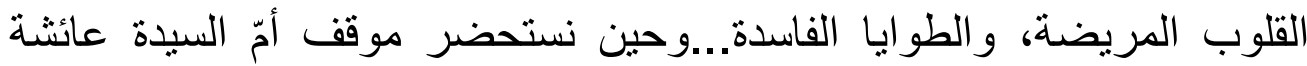
و هي تقول لها :"قومي إلى زوجك" تتساءل متعجبًا أيّ فرحة عمّت فؤادها، و أيّ اليّ

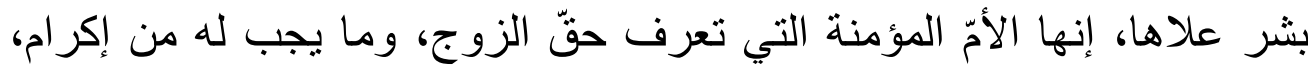

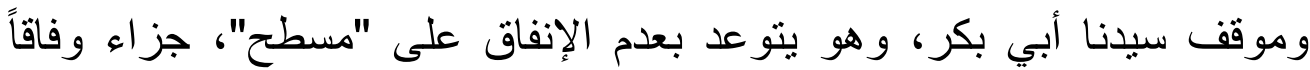

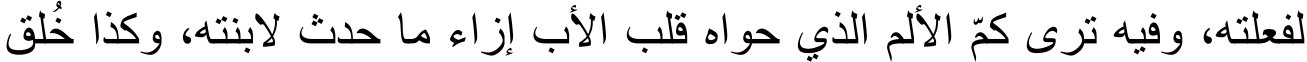

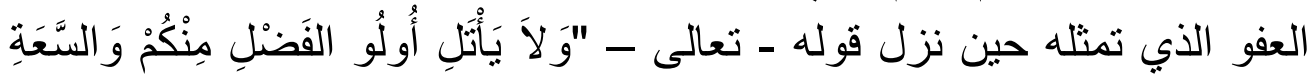

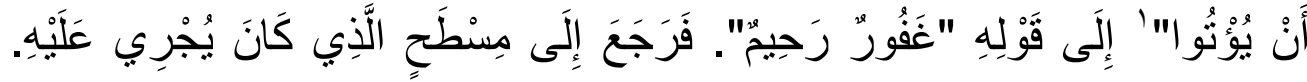


والبيت بيت نبوة، فلا عجب أن تجد فيه مثل السيدة زينب بنت جحش، التي

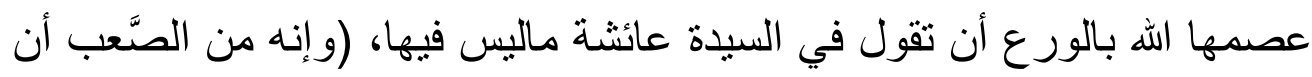

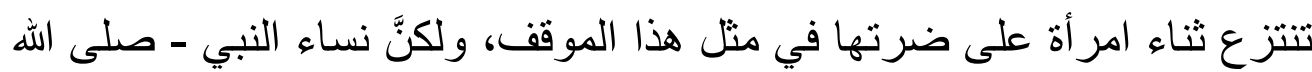

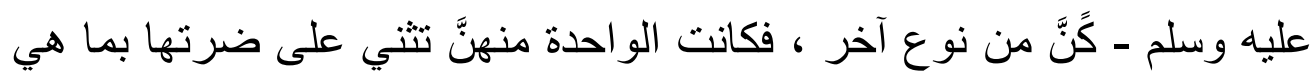

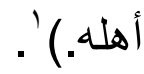

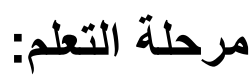

- عناية الله للمؤمنين، ومنحهم نعمة المعية، وهي أعلى و أغلى مزية، ومن

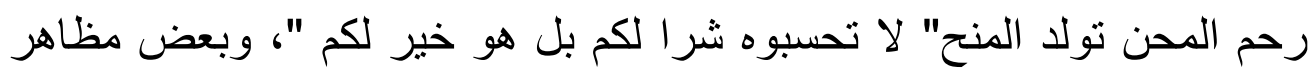

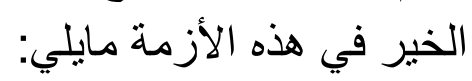
- أن يُعلم الإفلك خير من أن تظل هذه مايلي: الفرية البغيضة كائنة في صدور

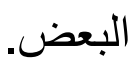

- رغم شدة الأزمة، لم يمنع النبي زوجه من إتيان أهلها، وهي تقصد

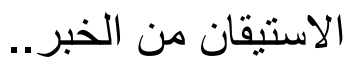

ـ الصبر على هذا الإيذاء المعنوي، وفي الصبر الصبر رفعة للارجات. ـ قد يعترض حل الأزمة تولا أزمات أخرى، فكن فئ حكيمًا. ـ في وسط ظلام الأزمة الدامس يسوق الله إليك من يحنو عليك، وهن وهم أكثر الداعمين للك نفسيا. - حين تضيق الأمور، وتشتد الأزمة يأتي تفويض الأمور و التسليم المطلق لله تعالى. - حيازة الثرف الأبدي في آيات تتلى إلى يوم القيامة حاملة إعلان البراءة و العفة. - استحقاق الخزي والعذاب الأليم لمن يعاود الثك في أمر حسمه القرآن الكريم. - دفاع الله عن المؤمنين، والموكلين أمر هم إليه، ليستحق كل خائض عقابه جز اء ما اكتسب من الإثم.

1 ـ معالم الأسرة النبويـة في القرآن الكريم، محمد سعيد محمد عنتري، جامعة النجاح الوطنية ـ

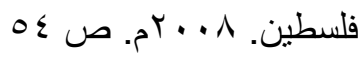


ـ لا يفتر أعداء الدعوة والمناهضون لها عن إثارة الثبهات والافتر اءات، مهما كانت سطحيتها، و عدم منطقيتها.

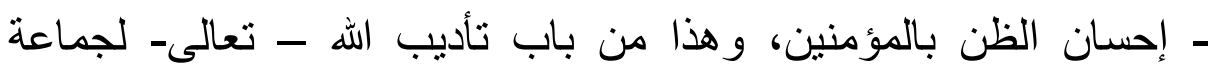

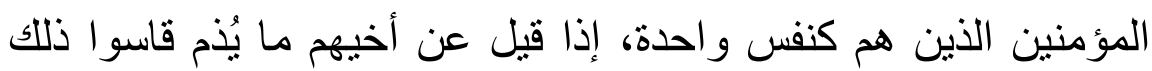

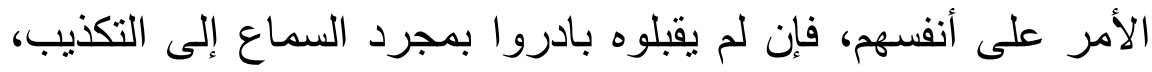
حتى عدّ إحسان الظن بالمؤمنين من مكارم الأخلاق ومحامدها.

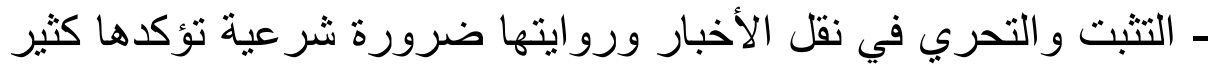

$$
\text { من الحوادث. }
$$

- خطورة الكلمة، فلربما بنطق اللسان بما يحسبه الناطق هينا، وهو عند

$$
\text { الله عظيم. }
$$

ـ العقاب الأليم لأصحاب الوشايات الكاذبة، و الساعون في إثاعة الفاحشة

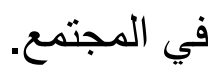

\section{المطلب الثاني}

\section{نماذج تطبيقية لأزمات أسرية عصرية}

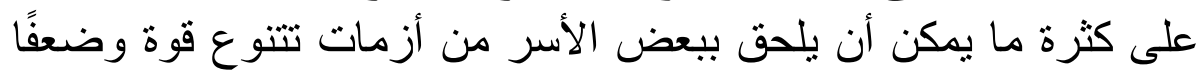

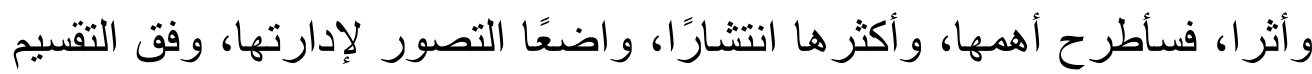

$$
\text { الآتي: }
$$

يعتقد البعض أن وجود مثل هذا النوع من الأزمات لا يشكل خطرًا على

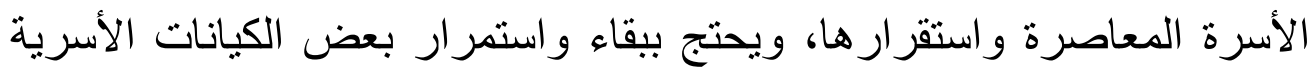

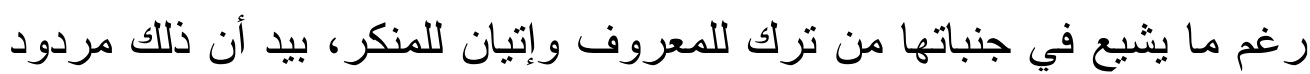

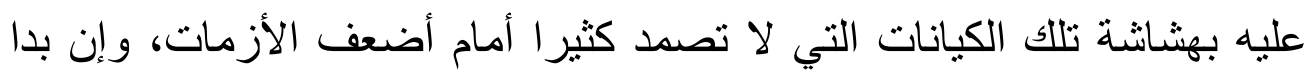
تماسكها ظاهرا، ففي الداخل حياة منغصة، وعيشا مكدرا، وما كثرة الأزمات

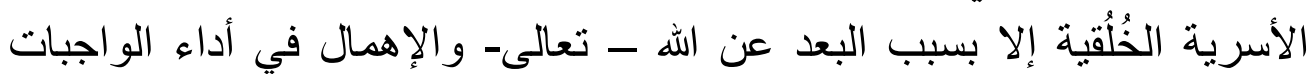

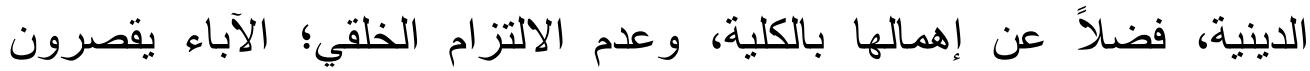


فيصدرون للأبناء قدوة سيئة، و الأبناء يفرطون، و آباؤهم يقصرون في المحاسبة،

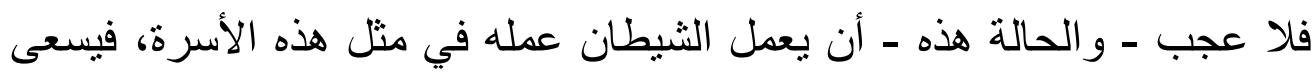

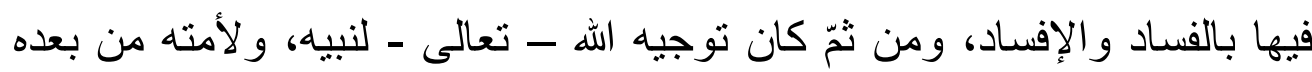

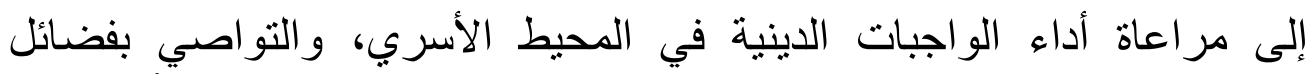

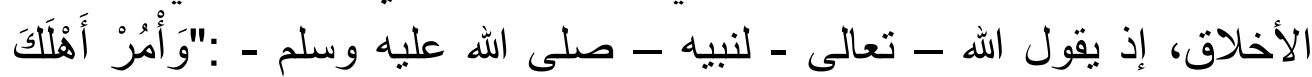

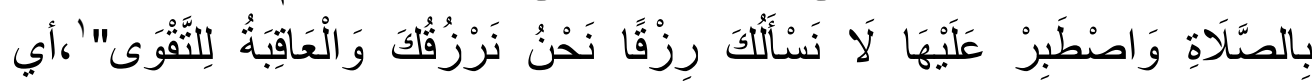

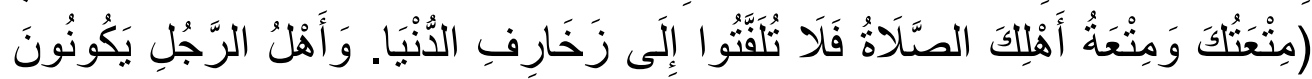

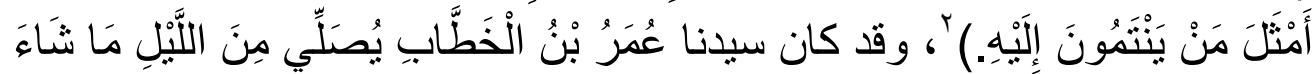

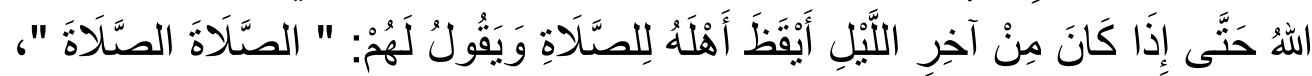

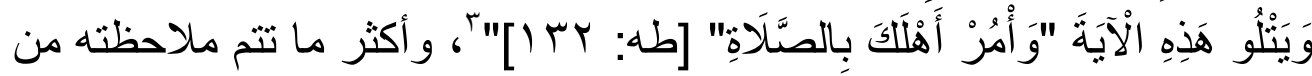

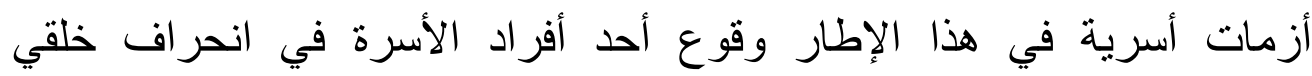

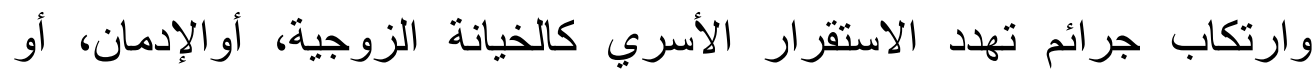

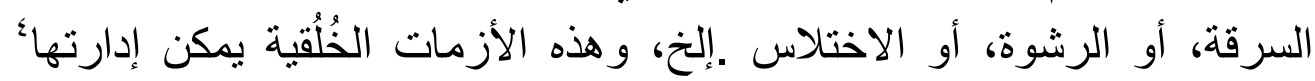
وفق ما يلي: - ماهن

\section{أ- مرحلة الإنذار المبكر}

ـ التساهل في أداء الواجبات الدينية، أو نركها بالكلية. - ملاحظة التغير السلوكي داخل وخارج الأسرة.

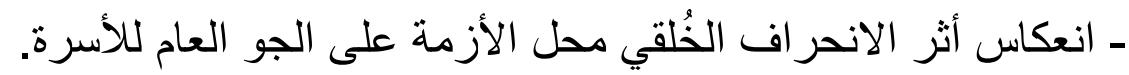
- ظهور أمار ات مادية بسبب المنكرات كل بحسبها. ب- مرحلة التخطيط ـ المواجهة و المبادرة في معالجة الأزمة. ـ النصح الرشيد و التوجيه السديد.

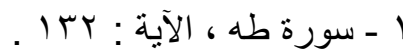

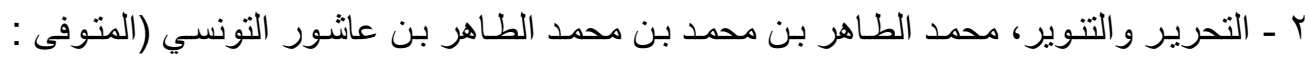

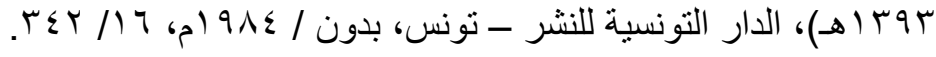

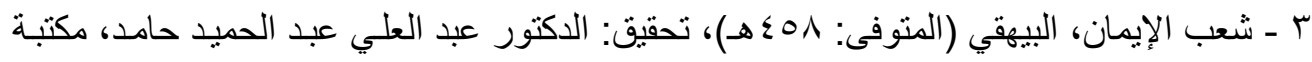

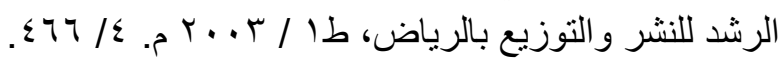

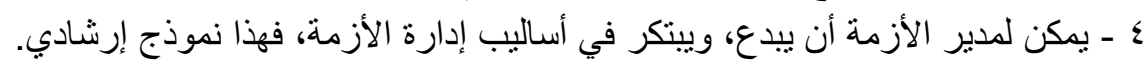


$-7 \leqslant 0$

- ممارسة الضغط الأسري من أجل الالتز ام المطلوب. ـ تجفيف منابع الانحر اف الخلقي محل الأزمة. ـ استحضار نماذج القدوات الصالحة للاقتداء. ـ الصبر في المعالجة والتقويم، و وعدم تعجل النتائج. - تدخل طرف خارجي عند الحاجة.

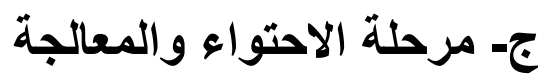
تفعيل بنود مرحلة التخطيط وفق الآتي:

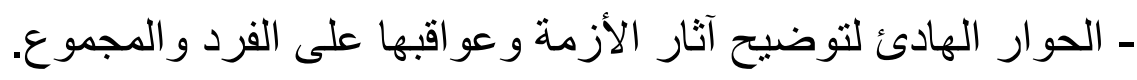

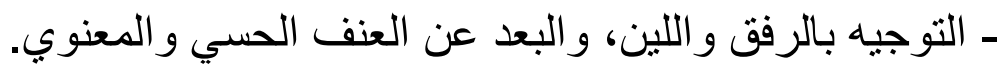

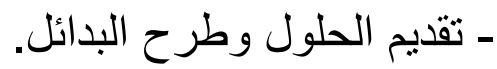

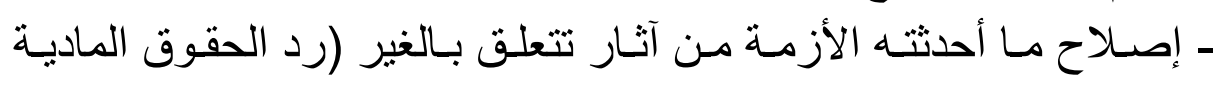
و المعنوية لأصحابها).

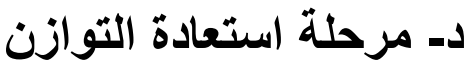
ـ تهدئة الأطر اف، وترميم ما فسد من الجو الأسري.

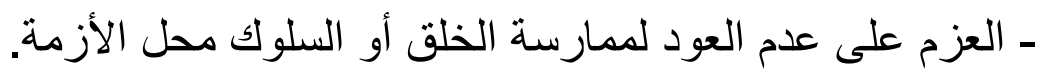

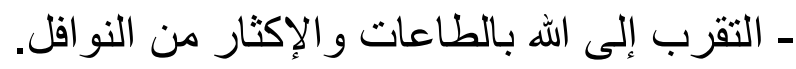

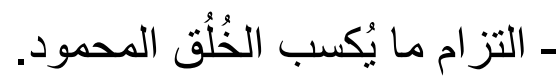
ـ التعاهد و الر عاية المستمرة. ه- مرحلة التعلم

- طاعة الله - تعالى - مجلبة للاستقر ار الأسري.

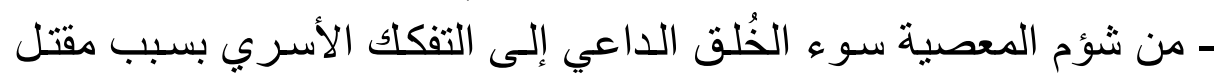
العائل أو سجنه أو عجزه عن العمل، و إهدار حقوق الأسرة.

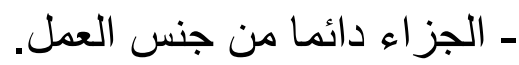

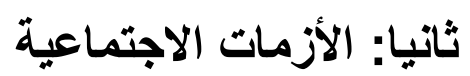

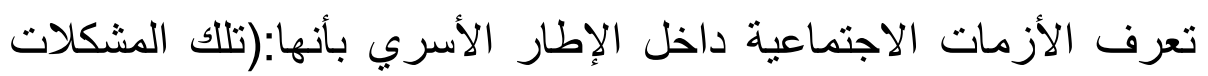

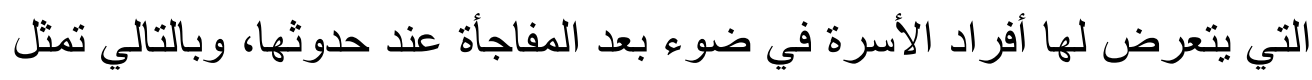

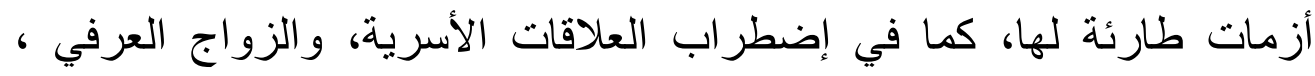


$-7 \leq 7$.

ورسوب أحد الأبناء، وأخير ا الحوادث الأليمة الغير متوقعة) '، وسبق القول بأن

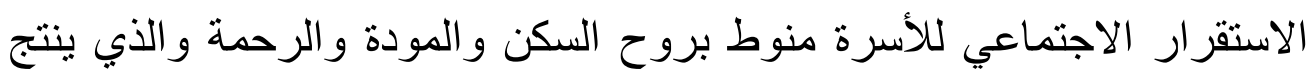
المعاثرة بالمعروف، والتوافق المشروع بين أفرادها، هذه الثناء الثاثية (السكن

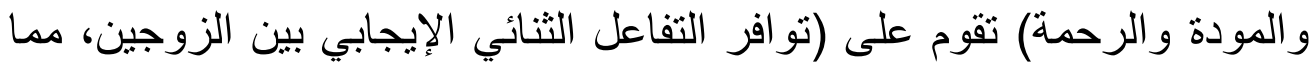

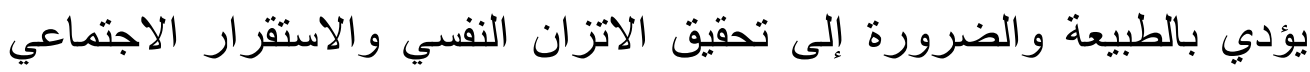

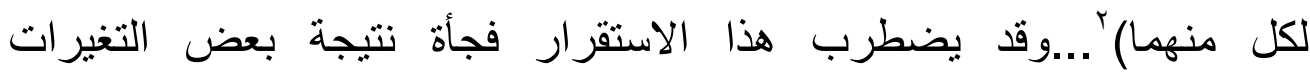

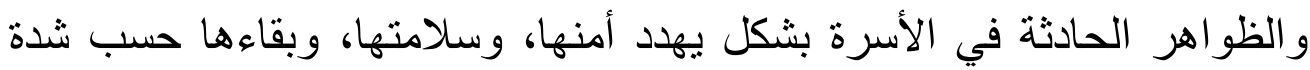

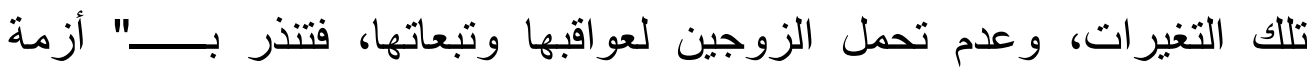

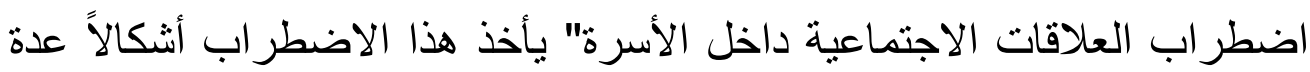

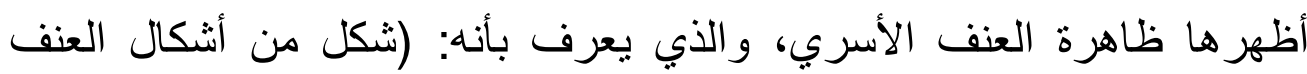

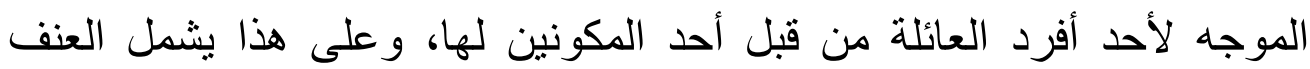

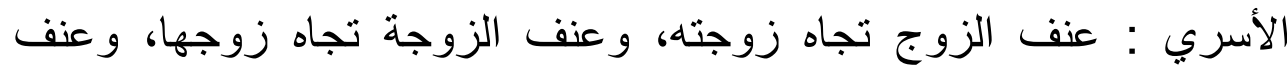

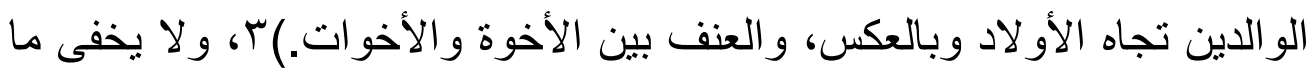

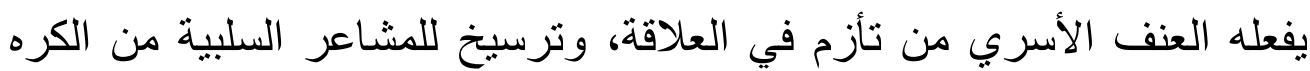

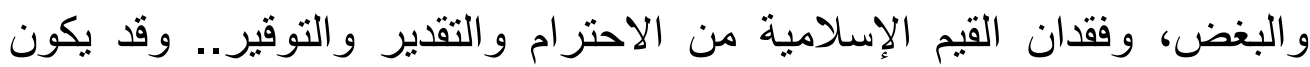

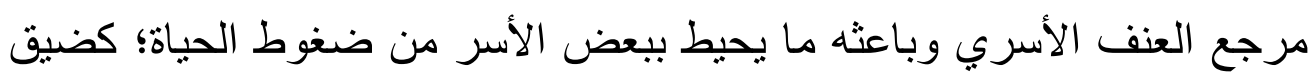

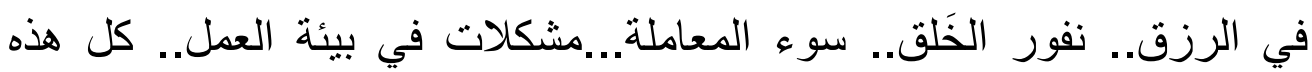

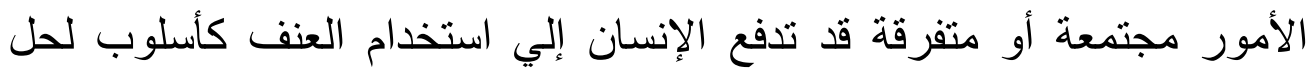
المشكلات، صغيرة كانت أو كبيرة..

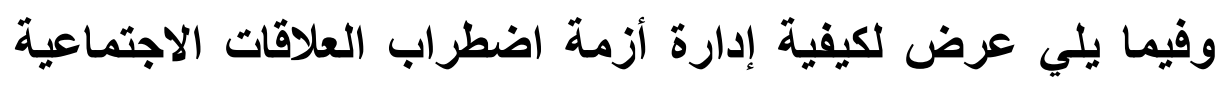

الأسرية:

ا ـ إدارة الأزمـات الأسـرية و علاقتها بالثقة بـالنفس لدي الأبنـاء بمحافظـة الفيوم، د. عفـاف عزت

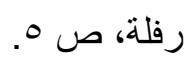

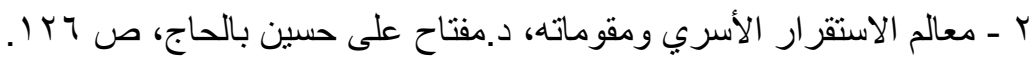

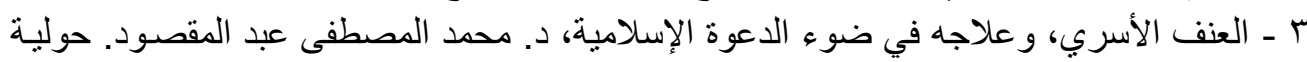

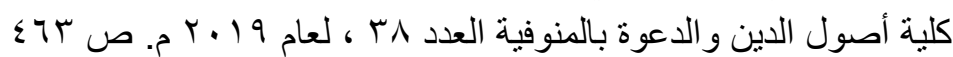


أ- مرحلة الإنذار المبكر

ـ الإعلان المستمر عن الضغوط النفسية في الحيز الأسري.

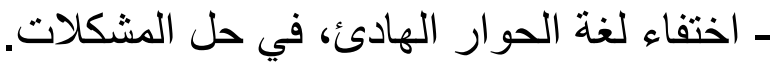

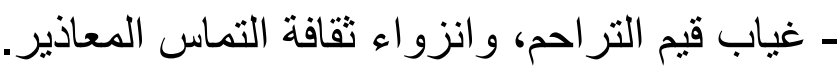
ـ تردي الوضع الاقتصـادي لاى بعض فئر الأسر. ب- مرحلة التخطيط

ـ الوقوف على الأسباب الحقيقية المؤدية للأزمة. - وضع خطة عملية للقضاء على أسباب الأزمة.

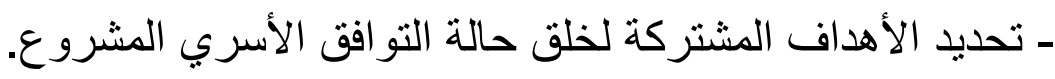
ـ التغيير الإيجابي لنمط الحياة الأسرية، وكسر الروتين.

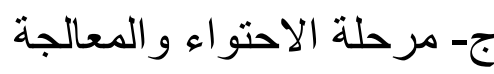

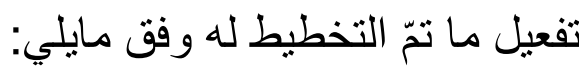

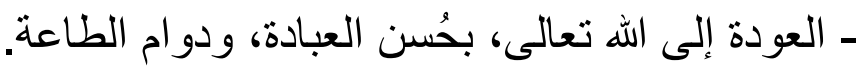

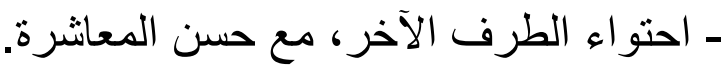

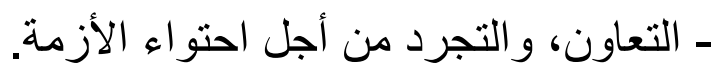
ـ استخدام أسلوب حواري هادئ وهادف. د- مرحلة استعادة التوازن التخ هوبن استنتناف الاستقرار الاجتمـاعي داخل الأسـرة، والمحافظلة على مكتسبات الأزمة، والابتعاد عن مسببات توتر العلاقات بين الزوجين.

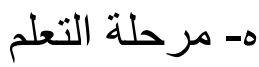

- مر اعاة الحقوق و الو اجبات أساس حُسن المعاثرة بين الزوجين.

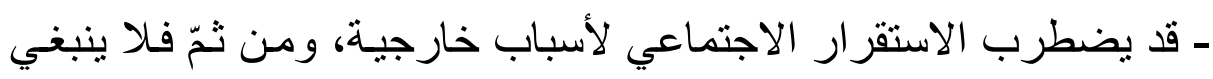
أن نحمل الآخرين التبعة و المسؤولية. ـ التضحية و إنكار الذات ناتج من نو اتج السكن و المودة ولئه والرحمة .

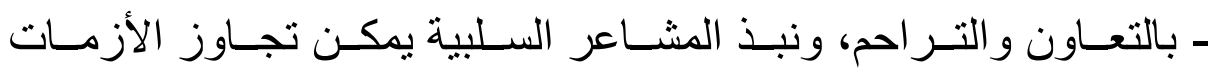
الاجتماعية.

ثالثا: الأزمات الاقتصادية تعرف الأزمات الأسرية الاقتصادية بأنها:(المواقف الغير منوقعة التي 
تنشأ بين أفراد الأسرة نتيجة تعرضها لمشكلات اقتصادية تابعة لاخل الوالدين ودخل الأبناء والتي تمثل أزمات يصعب التخلص منها بسبب لتعر عدم الثعور

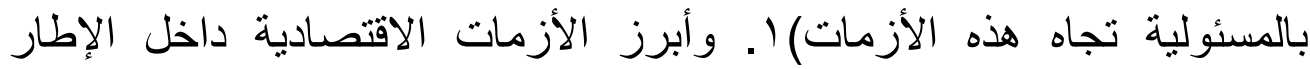

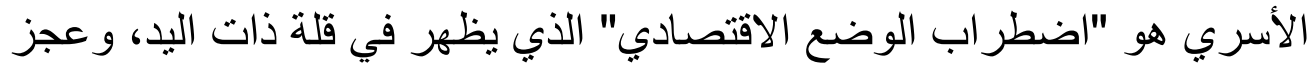

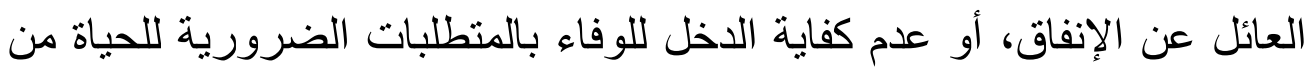

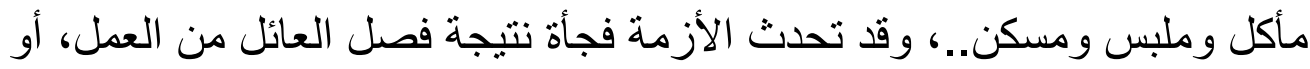

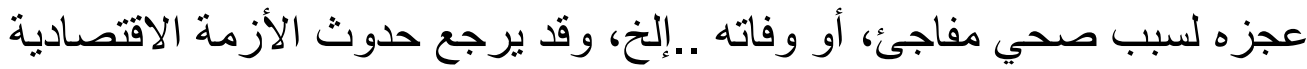

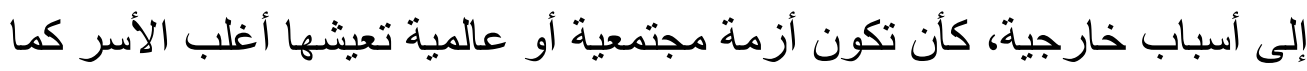

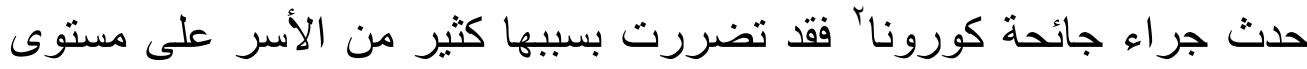
العالم، حيث لجأت الحكومات إلى تطبيق إجراءات احترازية، للحد من انتشار

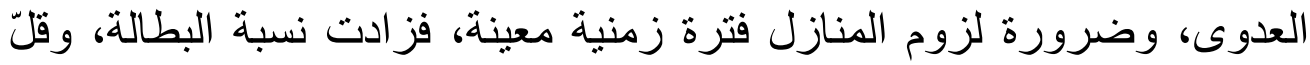

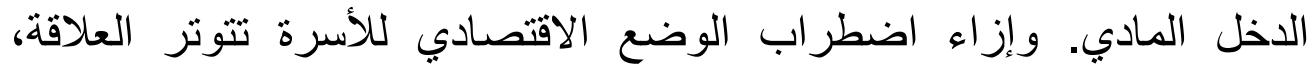

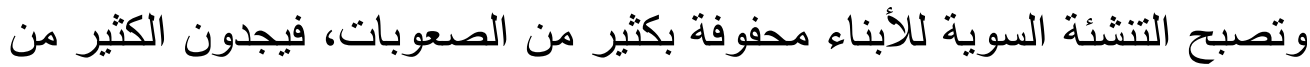

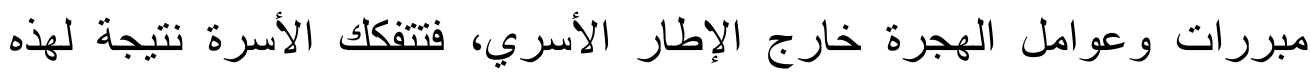

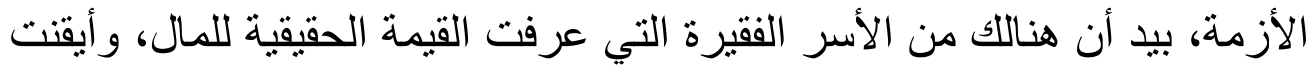

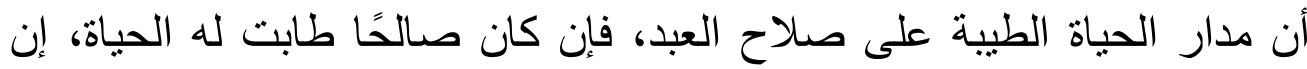

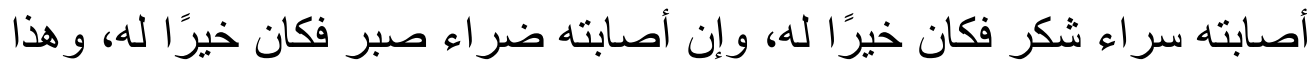
الصنف يشعر بالغني النفسي في فقره المادي، فازدادت أسر هم ترابطًا وتماسكًا،

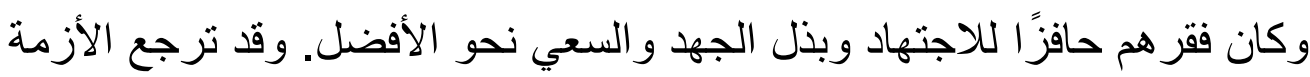

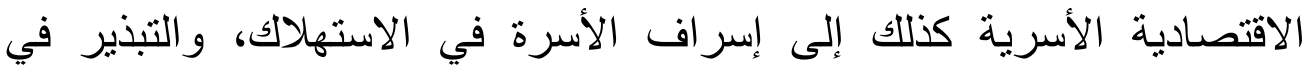
الإنفاق، والإخفاق في تدبير المعيشة، ومما يجب ذكره في هذا الباب أن النفقات

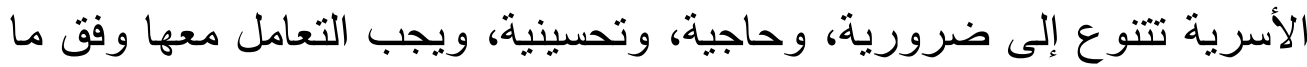

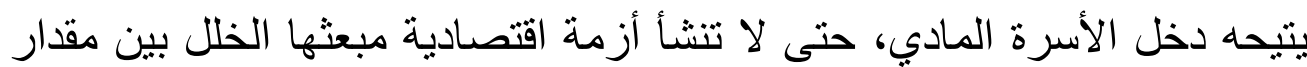
الاخل وحجم الإنفاق، والنفقات الضرورية هي ما لا بد منها وتقدم في الأولوية،

ا ـ إدارة الأزمـات الأسرية و علاقتها بالثقة بـالنفس لـي الأبنـاء بمحافظـة الفيوم، د. عفـاف عزت

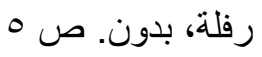

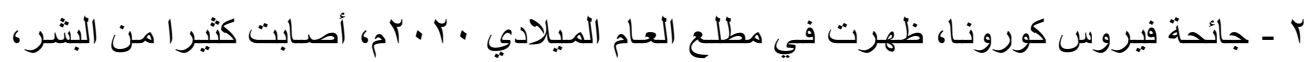
وتوفي بسيبها الكثيرون، ولا ز الت موجودة حتى كتابة البحث. 
$-7 \leqslant 9$

كالطعام والثراب و المسكن، و الملبس..إلخ، ثم يليها الحاجية التي تحتاجها

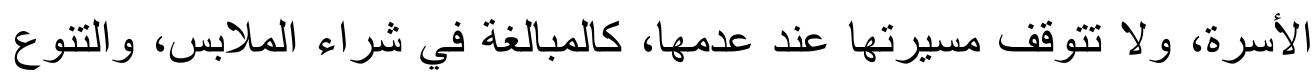

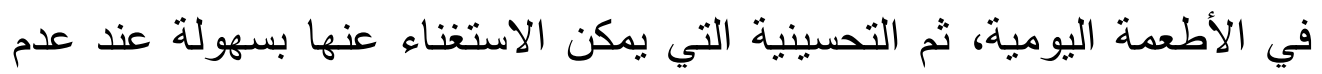

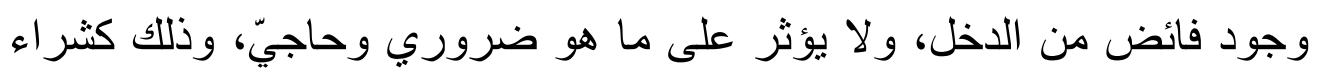

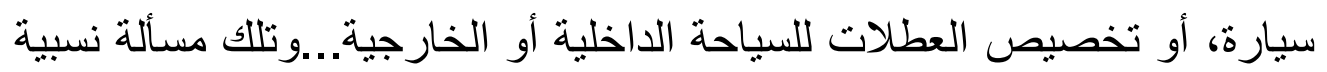
تختلف من أسرة لأخرى حسب تكوينها الاجتماعي، و التقافي، ومستو اها الماديّ،

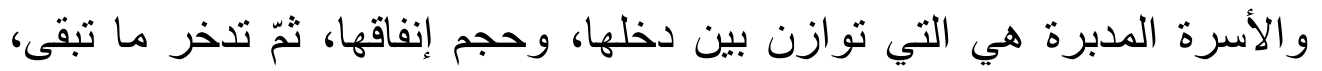
تحسبًا لعوارض الحياة من طوارئ وأزمات....هذا الادخار يسدّ على لئ الإنسان

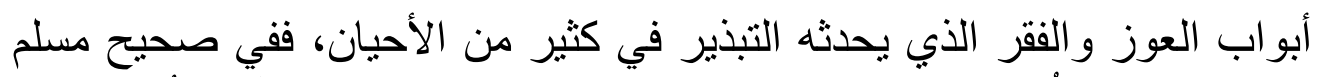
من حديث أبي أُمَامَةَ، قَالَ: قَالَ رَسُولَ اللهِ

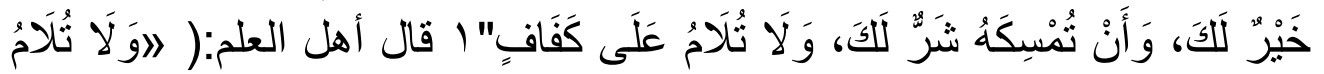

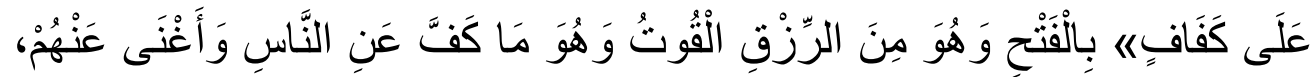

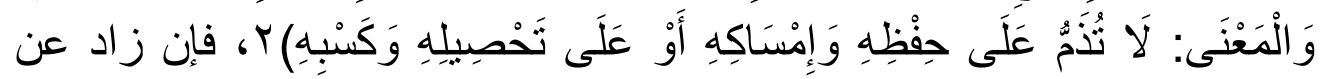
فضل حاجته وحاجة أو لاده ير غبه الإسلام في التصدق. و إلا كان بخيلا مذموما.

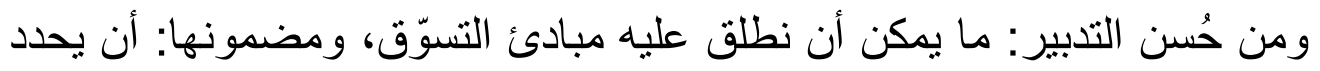

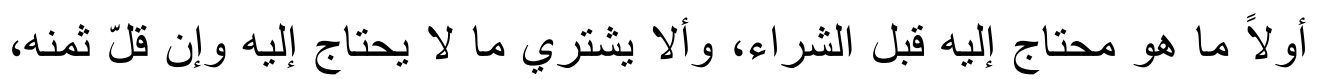
و أن بقتصد في التعامل مع شهوة الشراء، فلا بشتري كل ما تقع عليه عينه تلبية لحاجة نفسية، فهذا من باب الإسراف المنهي عنه شرعا. ومن حُسن التدبير

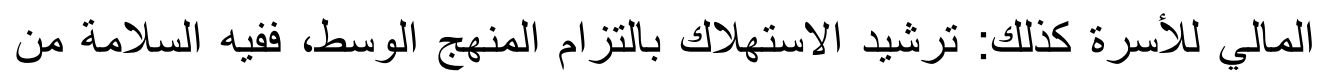
إضاعة المال الذي ينذر بالاقتر اب من خط الفقر، وحلول الأزمات الاقتصادية،

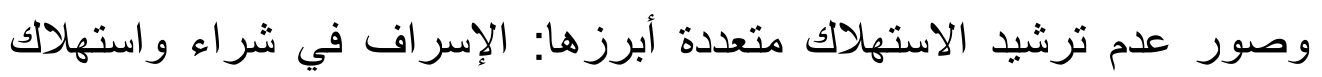

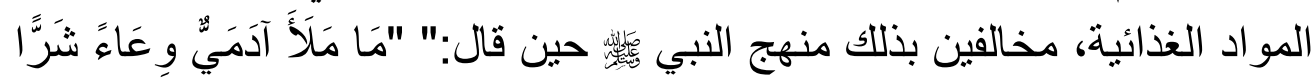

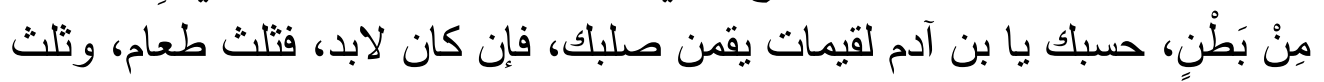

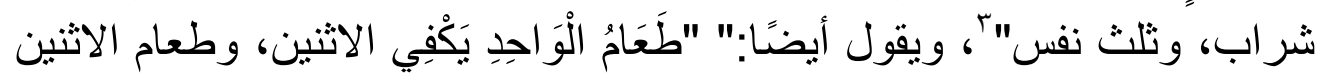

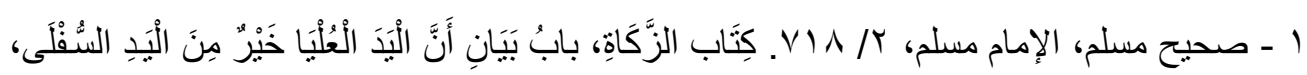

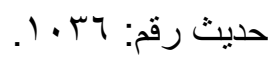

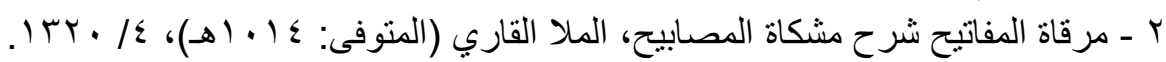

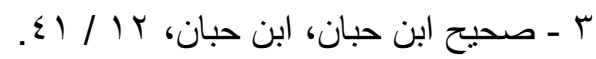




$$
-70 \cdot-
$$

يكفي الأربعة، وطعام لأربعة يكفي الثمانية"'، وفيما يلي عرض لكيفية إدارة أزمة اضطر اب الوضع الاقتصادي داخل الأسرة:

\section{أ- مرحلة الإنذار}

- عجز العائل عن الإنفاق.

ـ الأزمات الخارجية ذات التأثثر الواضح على اقتصاد الأسرة.

ـ الإسر اف و التبذير ، وسوء التدبير.

ـ التبطل و القعود عن العمل.

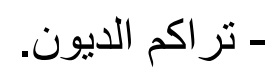

\section{ب- مرحلة التخطيط}

- معرفة مسببات الأزمة، ثمّ طرح الحلول والبدائل في حدود الإمكانات المتاحة.

ـ البحث عن عمل مناسب لمن قدر عليه. -الاستفادة مما تتيحة الدولة من رعاية الأسر الفقيرة. ـ الاستفادة من الدور الإيجابي للجمعيات الخيرية المشهرة في إعانة الأسر

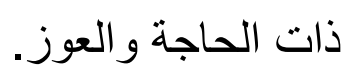

ـ الاستفادة من أثر العمل الخيري في المحافظة على التماسك الأسري. - توجيه أولو الأرحام بواجب المساعدة والتكافل الاجتماعي من أجل تجاوز الأزمة.

\section{ج- مرحلة الاحتواء والمعالجة}

$$
\text { تنفيذ ما جاء في مرحلة التخطيط وفق الآتي: }
$$

ـ التقرب إلى الله تعالى بالطاعات، وكثرة الدعاء، وملازمة الذكر. 


$$
-701 \text { - }
$$

- عدم اتخاذ الفقر و العوز ذريعة لافتعال المشكلات، واختلاق المنغصات. ـ التحلي بقيمة الرضا، والصبر في البأساء و الضراء. د- مرحلة استعادة التوازن - وجود دخل مادي يلبي الحاجات الضرورية. - تأهيل أفراد الأسرة لاستئناف الحياة، واستعادة نشاطها في القيام بأدور اهم داخل الأسرة وخارجها.

ـ التتبه لمسببات الأزمة، و العمل على تلافيها مستقبلا. ه- مرحلة التعلم ـ الإيمان و التقوى يفتحان على الأسرة بركات من السماء و الأرض. - شكر النعم سبب في بقائها وزياة، وكفر انها سبب زو الها. - ضرورة ترشيد الاستهلاك، وحسن التدبير المالي للأسرة. ـ الإنسان مستخلف في المال، ويجب أن يجلبه من حلّه وينفقه في حلّه. 


\section{خـاتمبهة}

إنّ الحمد لله، نحمده، ونستعينه، ونستهديه، ونعوذ بالله من شرور أنفسنا

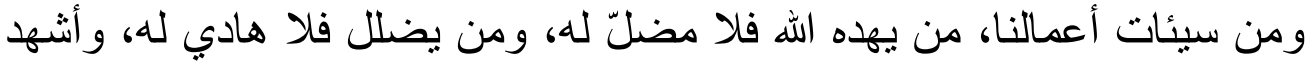

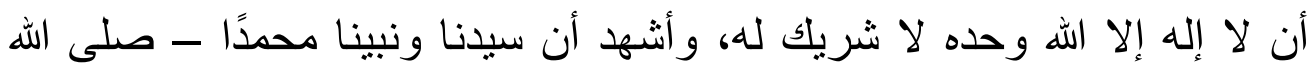
عليه وسلم- عبد الله ورسوله، وصفيه من خلقه وحبيبه، اللهح صلّ وسلم وبارك لكّله عليه و على آله، وصحبه أجمعين، ومن تبعهم بإحسان إلى يوم الدين ..آمين.

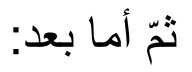

فبعد إتمام البحث - بحول الله تعالى - في موضوع:" إدارة الأزمات

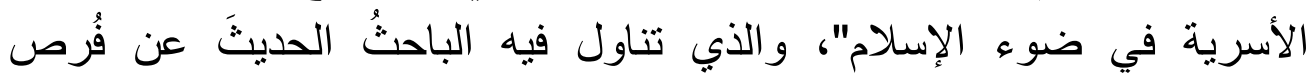

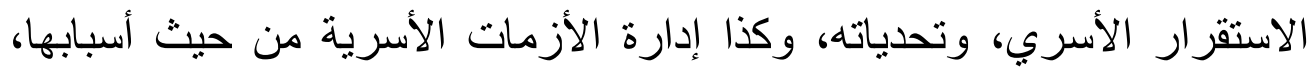

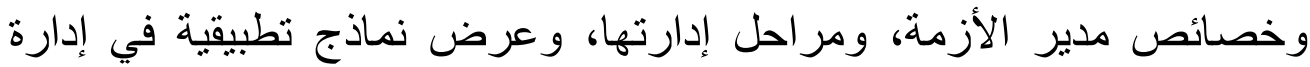
الأزمات الأسرية، فقد خلص إلى أهم النتائج على النحو الآتي: ـ أسبقية الإسـلام في الكثـف عن الفُرص التي تحقق الاستقرار الأسـري، و الدعوة إلى ضرورة الإفادة منها على المستوى الفردي والجي الجمعي. ـ كل فرصـة لتحقيـق الاسـتقر ار الأسـري يقابلهـا نـوع مـن التحـدي ينبغـي مجابهته في ضو ء أحكام الإسلام وتعاليمه.

ـ لمدير الأزمة عمو ما مجمو عة من المهار ات و الخصـائص و السمات ينبغي أن يتحلى بها مدير الأزمة الأسرية. ـ للأزمـات الأسـرية أسباب داخليـة وخارجيـة، ويجب أن تفطن لهـا الأسـرة

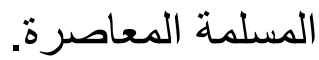
ـ احتو اء الإسـلام على منهج متكامـل في إدارة مـا يعرض للأسـرة مـن أزمـات مختلفة.

\section{وكاتث أهم التوصيات:}

- حتميـة العـودة إلىى المنبع الصـافي، و المـورد الكـافي المتمثل في الـوحي الإلهي، لاستخلاص بر امج توعوية، تسـهم في وضـع بر امج علميـة لإدارة 


$$
\text { الأزمات الأسرية على اختلاف أنواعها. }
$$

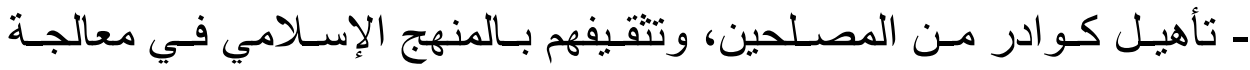

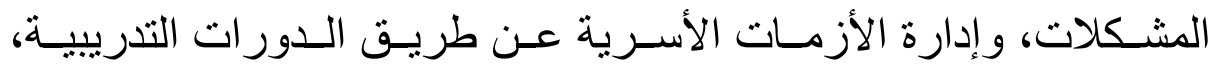

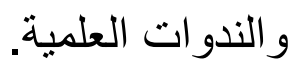

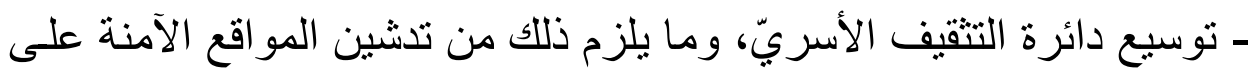

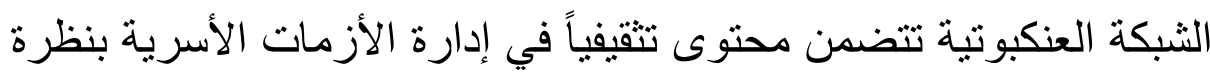

$$
\text { إسلامية. }
$$

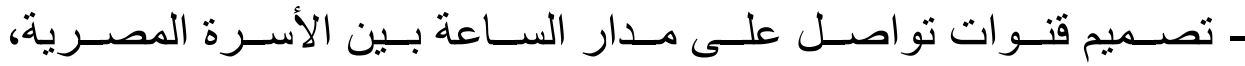
و المؤسسات المعنية بالإرشاد الأسري، من أرقام هاتفية، وتطبيقات ذكية..

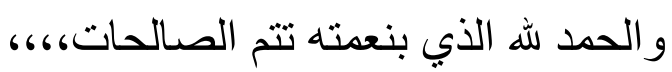




\section{المسادر والمراجع}

القر آن الكريم

ا - إحكام الإحكام شرح عمدة الأحكام، ابن دقيق العيد، بدون طبعة وبدون تاريخ.

Yـ إدارة ومعالجة الأزمات في الإسلام، د. سوسن الثيخ، دار النشر للجامعات.

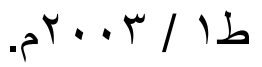
r- إدارة الأزمات الأسرية وعلاقتها بالتقة بالنفس لدي الأبناء بمحافظة الفيوم، د. عفاف عزت رفلة، بدون. عـ الإصلاح الأسري من منظور قر آني، يونس محمود صـادق ياسين، جامعة

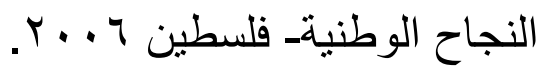

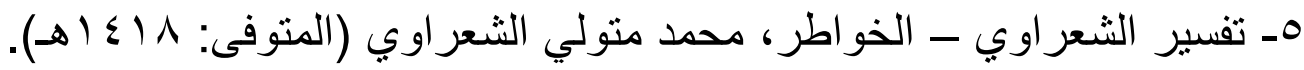

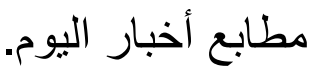

ד- تفسير الطبري، الطبري (المتوفى: · اسبه)، تحقيق: الدكتور عبد الله بن عبد الهب

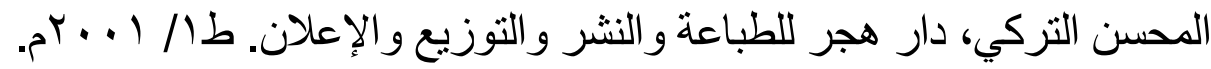

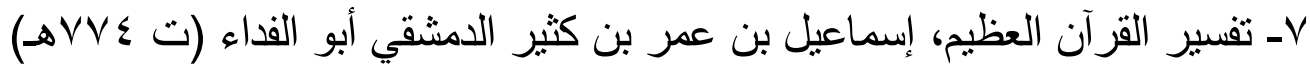

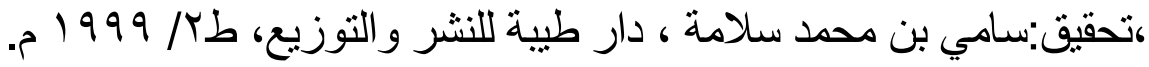

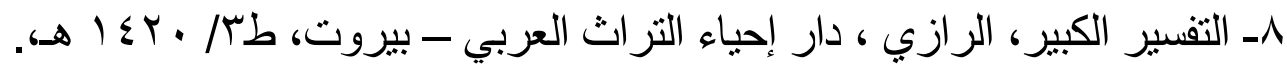

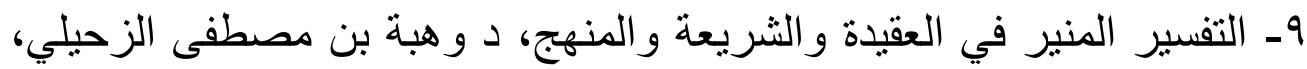

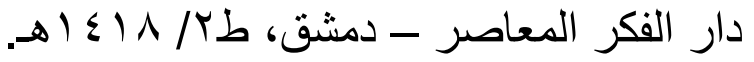

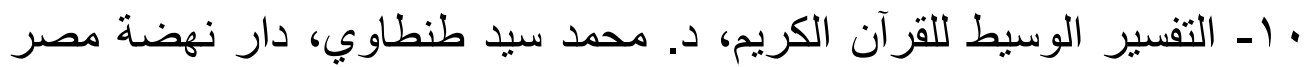

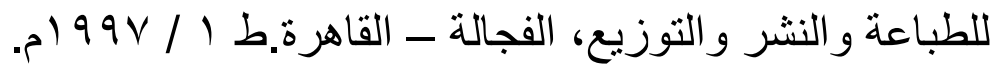
1 ا ـ التوافق الزواجي وعلاقته بالاستقرار الأسري لدى عينة من المتزوجين

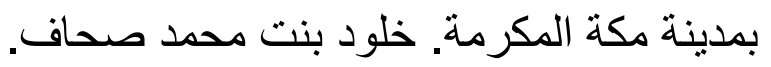

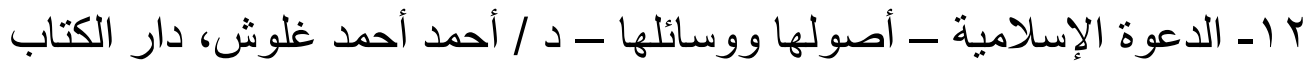

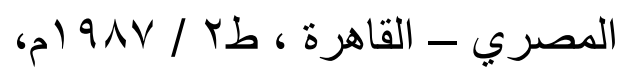

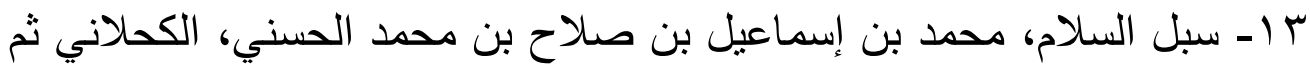

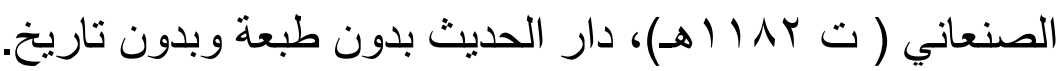

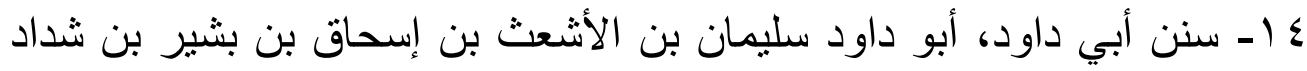


$-700$

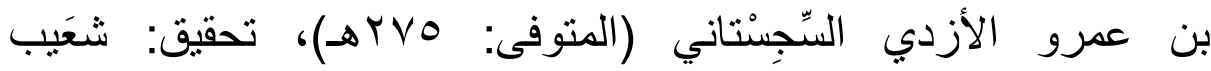

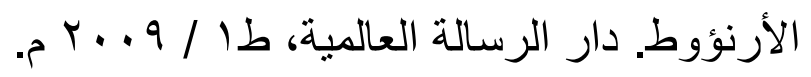

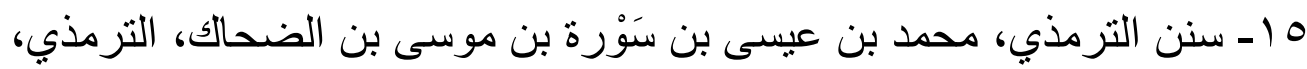

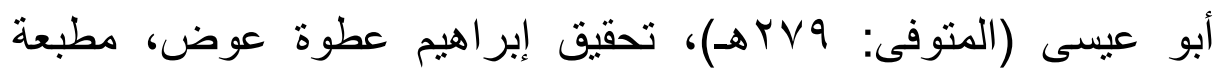

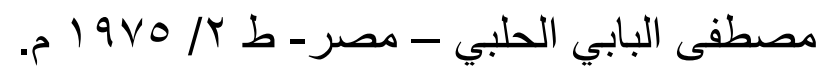
7 ا ـ شرح رياض الصالحين، محمد بن صالح بن محمد العثيمين (المتوفى:

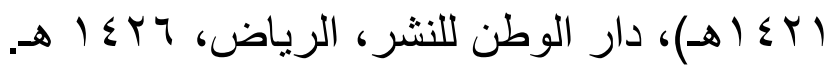

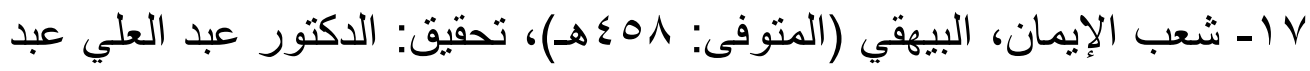

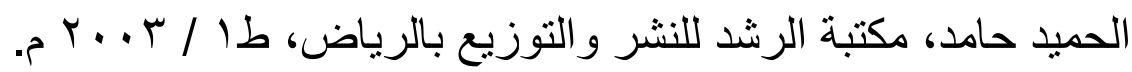
1 ا - صحيح ابن حبان، ابن حبان (المتوفى: ــ هـهـ)، تحقيق: شعيب الأرنؤوط،

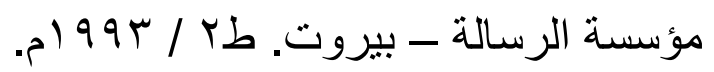

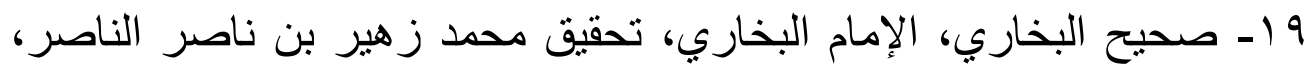

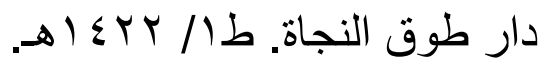

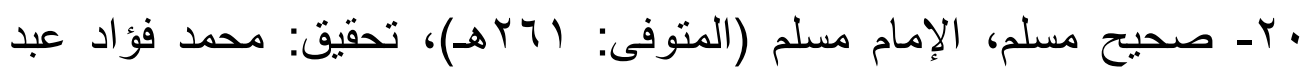

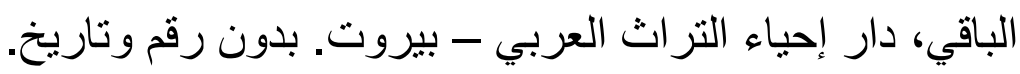

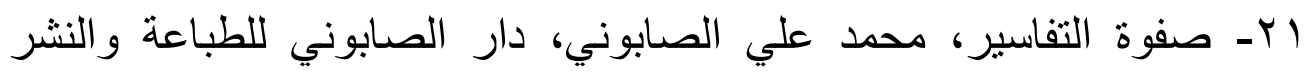

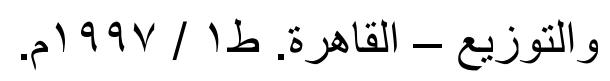

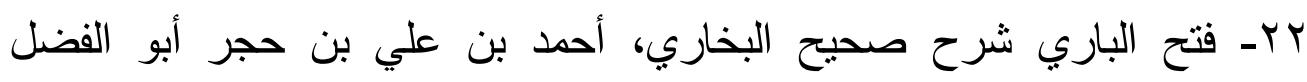

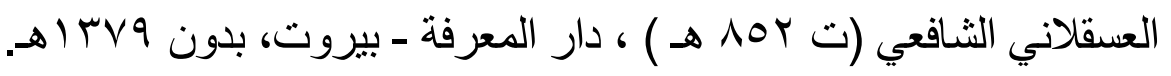

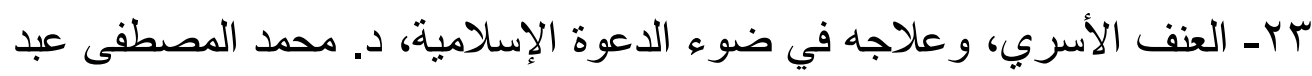

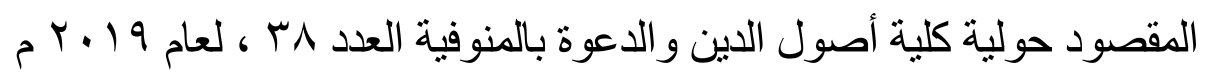

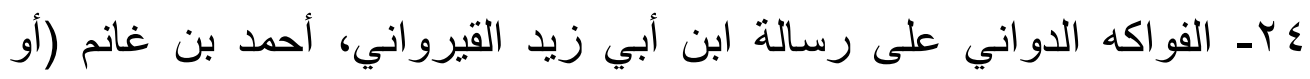

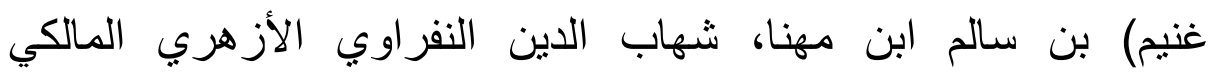

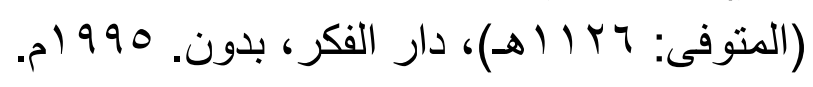

0 ــ فيض القدير شرح الجامع الصغير، عبد الرؤوف المناوي، الناشر المكتبة

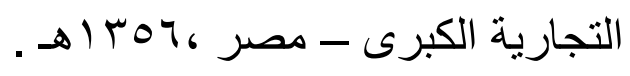

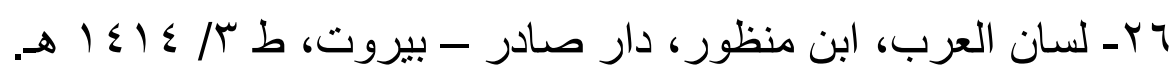

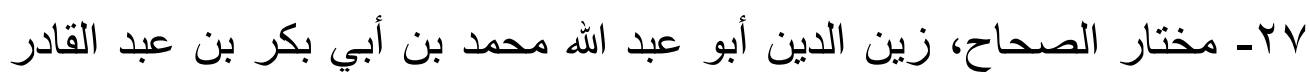


الحنفي الرازي (المتوفى: جا77هـ)، تحقيق: يوسف الثيخ محمد، المكتبة

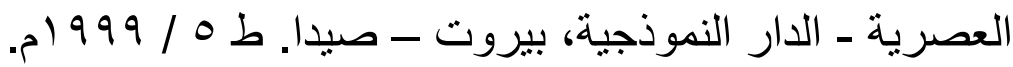

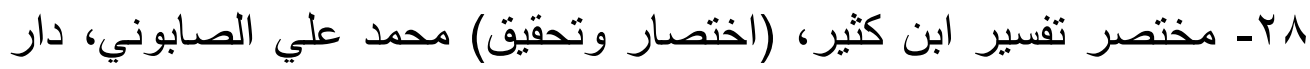

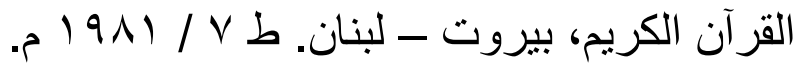

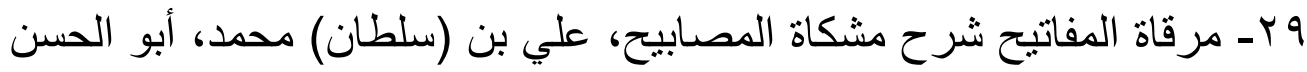

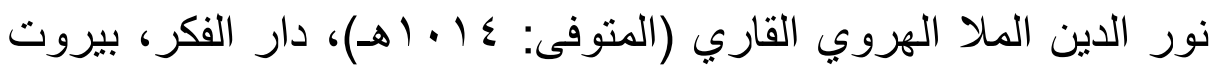

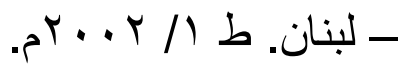

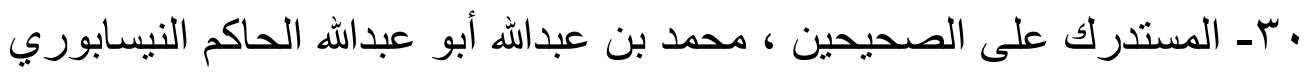

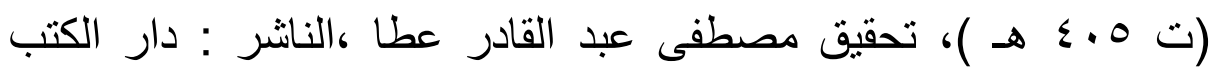

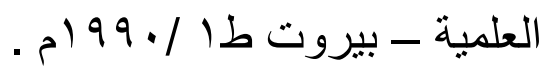

اس- مسند الإمام أحمد بن حنبل، لأبي عبد الله أحمد بن محمد بن حنبل بن هلال

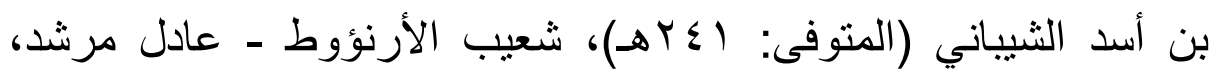

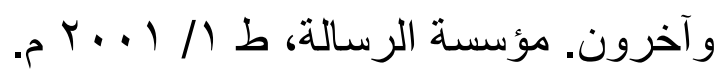

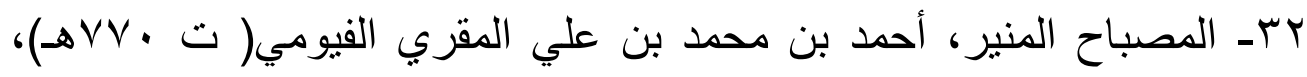
المكتبة العلمية- بيروت.

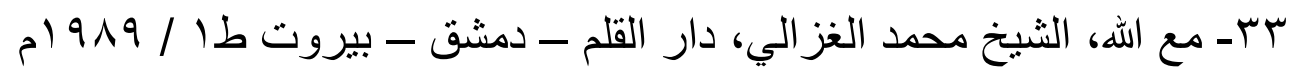
ع זـ معالم الاستقر ار الأسري ومقوماته، د. مفتاح علي حسين بالحاج.مجلة كلية الآداب - مصراته الاسئه. العدد التاسع. هـ- معالم الأسرة النبوية في القرآن الكريم، محمد سعيد محمد عنتري، جامعة الإدة

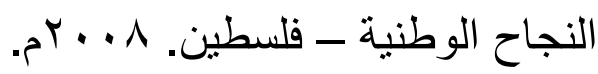

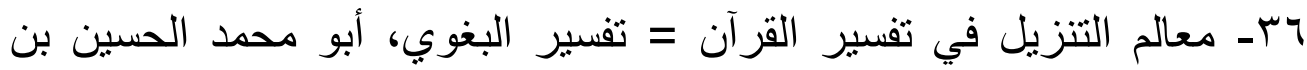

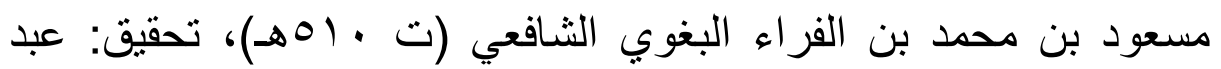

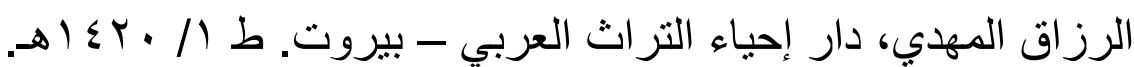

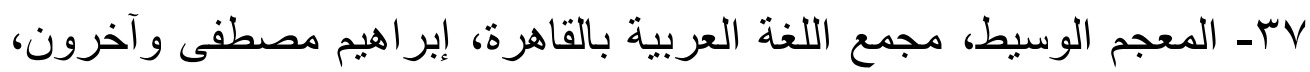
دار الدعوة- بلدون.

^ץ- معجم مقاييس اللغة، لأبي الحسين أحمد بن فارس بن زكريا (ت 90 بهـ)،

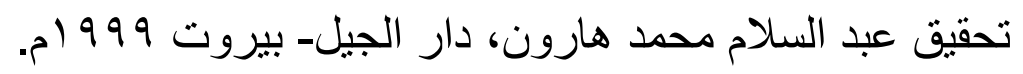
qبـ معجم اللغة العربية المعاصرة، د أحمد مختار عبد الحميد عمر (المتوفى: 


$$
\begin{aligned}
& -70 V_{-}
\end{aligned}
$$

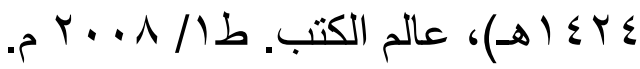

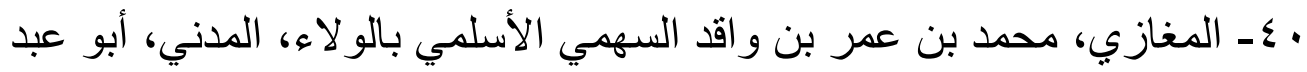

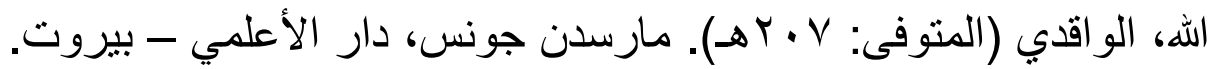

$$
\text { ط / } 9199
$$

ا ـ - مهار ات إدارة الأزمات و الكوارث و المو اقف الصعبة، د. محمد هيكل الهيئة

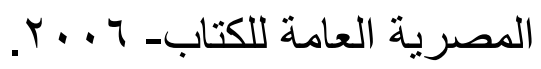

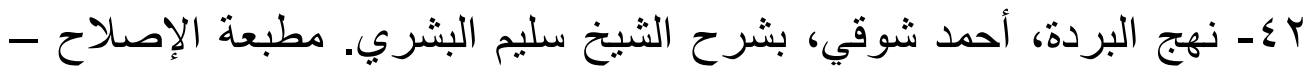

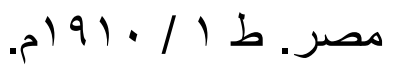

بــ- نيل الأوطار، محمد بن علي بن محمد بن عبد الله الثوكاني اليمني

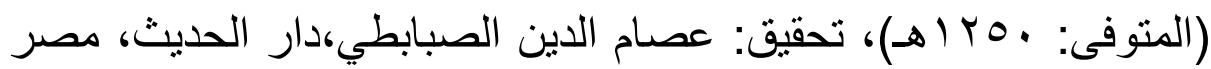

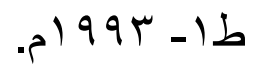

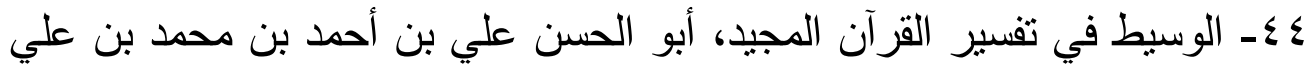

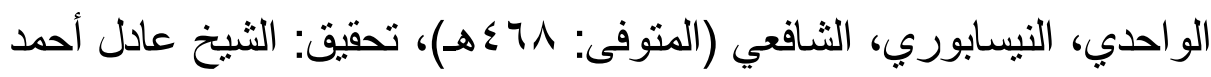
عبد الموجود وآخرون، دار الكتب العلمية، بيروت ـ لبنان. ط / / ع ـ 99 م. م.

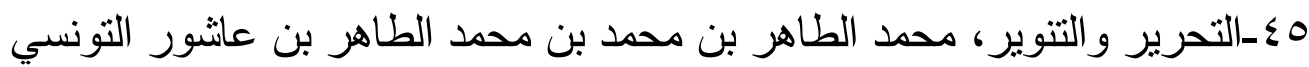

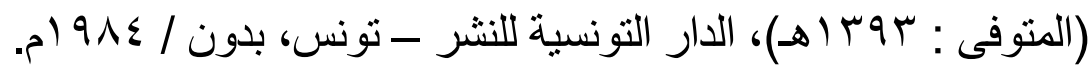

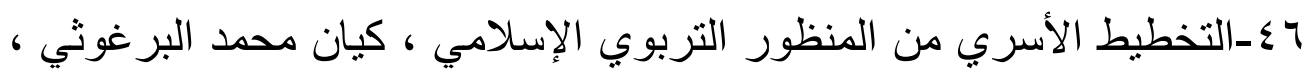

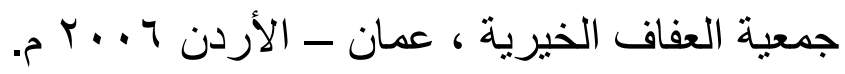

ع V V تعلم التخطيط في ساعات - مبادئ التخطيط والتخطيط التشغيلي- معهد

$$
\text { الكويت للأبحاث العلمية- V V . . Y م. }
$$

^ــ تفسير الإمام ابن عرفة، محمد بن محمد ابن عرفة الورغمي التونسي

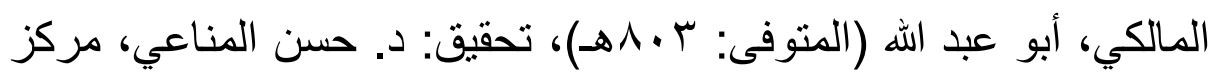

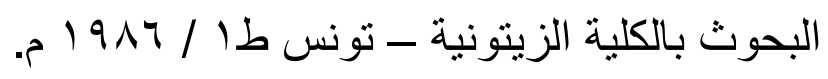

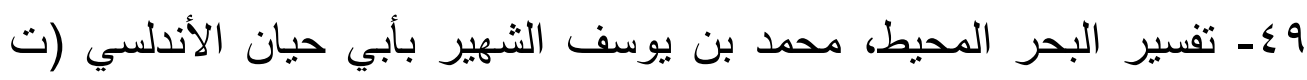

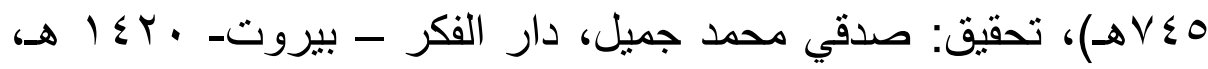

$$
\text { بدون رقم الطبعة. }
$$


$-701$

فهرس الموضو عات

\begin{tabular}{|c|c|}
\hline رقم الصفحة & الموضــوع \\
\hline ONH & المقدمة \\
\hline $0 \wedge 7$ & التمهيد \\
\hline 091 & المبحث الأول: الاستقر ار الأسري، فرص..وتحديات \\
\hline 710 & المبحث الثاني: إدارة الأزمات الأسرية \\
\hline ס & المبحث الثالث: نماذج تطبيقية \\
\hline $70 Y$ & الخاتمة. \\
\hline $70 \leqslant$ & المصادر و المر اجع. \\
\hline 701 & فهرس الموضو عات. \\
\hline
\end{tabular}

